Portugal in the European Context, vol. I Institutions and Politics 


\section{Portugal in the European Context}

vol. I: Institutions and Politics

(edited by José Manuel Leite Viegas, Helena Carreiras, and Andrés Malamud).

vol. II: Knowledge and Society

(edited by António Firmino da Costa, Fernando Luís Machado, and Patrícia Ávila).

vol. III: Welfare and Everyday Life

(edited by Maria das Dores Guerreiro, Anália Torres, and Luís Capucha).

\section{Other tittles by Celta Editora}

Maria Ioannis Baganha (editor), Immigration in Southern Europe

J. Caetano, A. Galego, C. Viera, I. Vieira, and E. Vaz, The European Union's Fifth Enlargement Isabel Estrada, Postnational Citizenship and the State

Maurizio Ferreira, Anton Hemerijck, and Martin Rhodes, The Future of Social Europe. Recasting Work and Welfare in the New Economy

Virgínia Ferreira, Teresa Tavares, and Sílvia Portugal (editors), Shifting Bonds, Shifting Bounds. Women, Mobility, and Citizenship in Europe

José Manuel Leite Viegas and António Firmino da Costa (editors), Crossroads to Modernity. Contemporary Portuguese Society 
José Manuel Leite Viegas, Helena Carreiras and André Malamud (editors)

Portugal in the European Context, vol. I

\title{
Institutions and Politics
}

\author{
Alan Stoleroff \\ André Freire \\ Andrés Malamud \\ António Pedro Dores \\ Elsa Pegado \\ Filipa Pinho \\ Graça Carapinheiro \\ Helena Carreiras \\ João Sebastião \\ José Manuel Leite Viegas \\ Luís Capucha \\ Luís de Sousa \\ Rui Pena Pires \\ Sandra Palma Saleiro \\ Sérgio Faria \\ Sónia Vladimira Correia
}

CIES, ISCTE-UL CELTA EDITORA I Lisbon, 2009 
José Manuel Leite Viegas, Helena Carreiras, and André Malamud (editors)

Portugal in the European Context, vol. I: Institutions and Politics

First published 2009 by Celta Editora Lda

ISBN: 978-972-774-265-3

D.1.:

Set in 10 on 12 pt Palatino by Celta Editora

Printed in Spain by Publidisa

Cover design by Mário Vaz \& Celta Editora

Cover illustration: Amadeo de Souza-Cardoso (1887-1918), Procissão Corpus Christi, 1913, reproduced by kind permission of the Center of Modern Art, Calouste Gulbenkian Foundation, Lisbon

All rights reserved by Celta Editora Lda.

Excepted for the quotation of short passages for the purposes of criticism and review, no part of this publication may be reproduced, stored in a retrieval system, or transmitted, in any form or by any means, electronic, mechanical, photocopying, recording or otherwise, whithout the prior permission of the publisher.

\section{Celta Editora}

Postal adress: Apartado 151, 2781-901 Oeiras, Portugal

Tel: (+351) 9177750272

E-mail: celtaeditora@gmail.com 


\section{Table of contents}

List of figures and tables .................................................................... vii

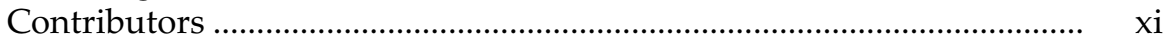

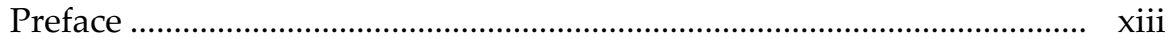

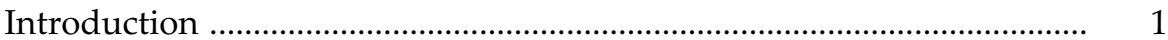

José Manuel Leite Viegas, Helena Carreiras, and Andrés Malamud

\section{Part I | INSTITUTIONS, IDEOLOGIES AND POLITICAL BEHAVIOURS}

1 Supranational parliaments in Europe and Latin America: between empowerment and irrelevance

Andrés Malamud and Luís de Sousa

2 Ideological identities in Europe: comparative perspective of Portugal, Spain and Greece. André Freire

3 Political participation: the Portuguese case from a European comparative perspective

José Manuel Leite Viegas and Sérgio Faria

\section{Part II | INSTITUTIONS AND PUBLIC POLICIES}

4 Social development policies: employment and social security ..... 71 Luís Capucha, Elsa Pegado, and Sandra Palma Saleiro 
5 The democratisation of school education in Portugal

João Sebastião and Sónia Vladimira Correia

$6 \quad$ Immigration policies in Portugal

Rui Pena Pires and Filipa Pinho

7 The Portuguese Armed Forces: changes and continuities at the turn of the millennium

Helena Carreiras

\section{Part III | INSTITUTIONS, SOCIAL RELATIONS} AND REPRESENTATIONS

8 Health and risk in Portuguese society: for a new agenda on policies regarding life Graça Carapinheiro

9 Penitentiary risk and prohibitionist spirit António Pedro Dores

10 Company-level labour relations and the industrial relations system in Portugal Alan Stoleroff 


\section{List of figures and tables}

\section{Figures}

2.1 Lelf-right self-placement in Europe, 1976-2002 (average percentage by decade) .................................................. 37

4.1 Total social protection expenditure (\% GDP), 1994-2002 ............. 80

4.2 Expenditure on social protection in PPS per capita, 2001 ............... 81

4.3 Total social protection expenditure in PPS per capita, 1994-2002 .... 82

4.4 Social protection by function (\% of total expenditure on social benefits), 2002 .............................................................................. 82

4.5 Employment rate in the EU 25, by sex, 2004Q2 (\%) ....................... 91

5.1 Illiterate or totally uneducated population, Portugal (\%) ............. 105

5.2 Resident population by completed level of schooling, Portugal (\%) 106

5.3 Population with compulsory schooling, Portugal (\%) .................. 107

5.4 Deviation from normal age for attending $2^{\text {nd }}$ cycle, by age, Portugal (\%)

5.5 Deviation from normal age for attending $3^{\text {rd }}$ cycle by age, Portugal (\%)

5.6 Pre-school rate in mainland Portugal (1984-2002) (\%) .................. 112

5.7 Resident population by geographical area and by level of education, Portugal (\%)

7.1 Total military personnel and conscripts in the Portuguese Armed Forces (1981-2005)

7.2 Percentage of women in the armed forces of NATO, 2006 ........... 167

7.3 Occupational distribution of female soldiers in NATO and Portugal (2000) $(\%)$

7.4 Hierarchical distribution of female military professionals in NATO and in Portugal (\%) (2000)

9.1 Risk of incarceration and crime rate in Portugal 202 


\section{Tables}

1.1 Comparative features of the european parliamentary assemblies

1.2 European parliament: seats per country (in alphabetical order according to the country's name in its own language)

1.3 Political composition of the european parliament, 1979-2004 (number of seats per political group)

1.4 Comparative features of five regional parliaments

2.1 Left-right self-placement in Europe, 1976-2002 (OLS regressions)

2.2 Evolution of left-right alignments in Europe, per decade, 1976-2002

2.3 Short-term shifts in left-right alignments in Europe between 1976 and 2002 (I) (difference in percentages)

2.4 Short-term shifts in left-right alignments in Europe between 1976 and 2002 (II) (difference in percentages)

3.1 Frequency of the different forms of political participation, by country $(\%)$

3.2 Principal component factor analysis of forms of political participation

3.3 Index of the types of political participation ...................................... 64

4.1 Main indicators of the labour market ……….................................. 92

4.2 Highest level of education (Portugal and EU15 2002) (\%) ............ 95

4.3 Gross Added Value structure by sector of activity in Portugal and the EU15, 1998

5.1 Students in TEIP after joining schools in the Mainland Programme (\%)

5.2 Educational careers of students by school, 2003/2004 _................ 120

5.3 Educational careers of students by social class, 2003/2004 .......... 121

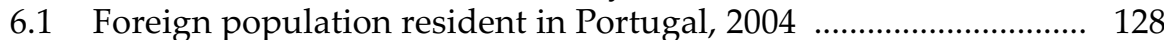

6.2 Changes in the law on nationality ................................................. 133

6.3 Chronology of basic immigration legislation, 1976-2005 .............. 146

7.1 Armed Forces in the Three Eras ..................................................... 155

9.1 Evolution of the number of prison guards in Portugal,

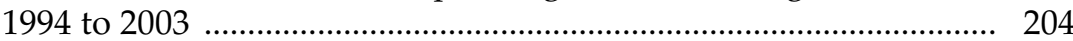

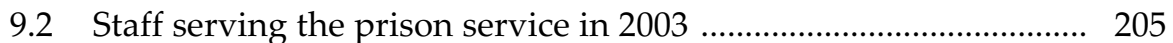

9.3 Deaths in Portuguese prison establishments between January 1

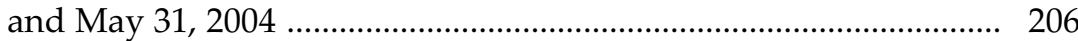

9.4 Deaths in Portuguese prison establishments ................................ 207

9.5 Non-nationals in Portuguese prisons 2003 .................................... 207

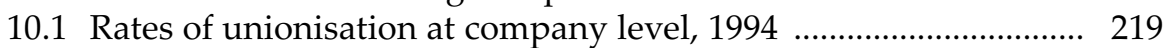

10.2 Representative structures at company level, $1994(\%)$.................. 219 
10.3 Rate of unionisation at company level/sector of activity, $2003(\%)$

10.4 Representative structures at company level, 2003 (\%)

10.5 Primary mode of regulation of work relations in the company, $2003(\%)$

10.6 Process of wage fixing, 2003 ( $\%$ and valid \%)

10.7 Wage determination, by sector, 2003 (\%)

10.8 Process of fixing working conditions of personnel, 2003 (\% and valid \%)

10.9 Holding of information meetings, $2003(\%)$

10.10 Opinion with regard to the role of unions in the view of the company, 1994 (\%)

10.11 Characterisation of the role of the unions, $1994(\%)$

10.12 Characterising the role of unions from the perspective of the company, 2003 (\%)

10.13 Role of unions from the perspective of the company by sector ... 231 



\section{Contributors}

Alan Stoleroff is professor in the Department of Sociology and researcher in the Centre for Research and Studies in Sociology (CIES), at ISCTE - Lisbon University Institute.

André Freire is professor in the Department of Sociology and researcher in the Centre for Research and Studies in Sociology (CIES), at ISCTE - Lisbon University Institute.

Andrés Malamud is a senior researcher at the Institute of Social Sciences of the University of Lisbon and an associated researcher to the Centre for Research and Studies in Sociology (CIES) at ISCTE - Lisbon University Institute.

António Pedro Dores is professor in the Department of Sociology and researcher in the Centre for Research and Studies in Sociology (CIES), at ISCTE - Lisbon University Institute.

Elsa Pegado is researcher in the Centre for Research and Studies in Sociology (CIES) at ISCTE - Lisbon University Institute.

Filipa Pinho is researcher in the Centre for Research and Studies in Sociology (CIES) at ISCTE - Lisbon University Institute.

Graça Carapinheiro is professor in the Department of Sociology and researcher in the Centre for Research and Studies in Sociology (CIES), at ISCTE - Lisbon University Institute.

Helena Carreiras is professor in the Department of Sociology and researcher in the Centre for Research and Studies in Sociology (CIES), at ISCTE Lisbon University Institute.

João Sebastião is professor in Escola Superior de Educação de Santarém (Santarém School of Education) and researcher in the Centre for Research and Studies in Sociology (CIES) at ISCTE - Lisbon University Institute.

José Manuel Leite Viegas is professor in the Department of Sociology and researcher in the Centre for Research and Studies in Sociology (CIES), at ISCTE - Lisbon University Institute. 
Luís Capucha is professor in the Department of Sociology and researcher in the Centre for Research and Studies in Sociology (CIES), at ISCTE - Lisbon University Institute.

Luís de Sousa is a senior researcher at the Institute of Social Sciences of the University of Lisbon and an associated researcher to the Centre for Research and Studies in Sociology (CIES) at ISCTE - Lisbon University Institute.

Rui Pena Pires is professor in the Department of Sociology and researcher in the Centre for Research and Studies in Sociology (CIES), at ISCTE - Lisbon University Institute.

Sandra Palma Saleiro is researcher in the Centre for Research and Studies in Sociology (CIES) at ISCTE - Lisbon University Institute.

Sérgio Faria is researcher in the Centre for Research and Studies in Sociology (CIES) at ISCTE - Lisbon University Institute.

Sónia Vladimira Correia is researcher in the Centre for Research and Studies in Sociology (CIES) at ISCTE - Lisbon University Institute. 


\section{Foreword}

This volume is part of a trilogy organised by the Centre for Research and Studies in Sociology (CIES), at ISCTE - Lisbon University Institute. It presents a broad range of recent analyses of contemporary society, placing Portugal in the European Context. The trilogy is made up of three volumes:

\section{vol. I Institutions and Politics}

(edited by José Manuel Leite Viegas, Helena Carreiras, and Andrés Malamud);

vol. II Knowledge and Society

(edited by António Firmino da Costa, Fernando Luís Machado, and Patrícia Ávila);

vol. III Welfare and Everyday Life

(edited by Maria da Dores Guerreiro, Anália Torres, and Luís Capucha).

The aim of the publication is to share with the public the findings of national and international studies carried out by CIES researchers in recent years. Bringing the studies together within this trilogy required a re-examination of data and analyses, the end result of which has been to promote a better understanding of present day society.

These advances in understanding contemporary social life are structured around three thematic perspectives. Each volume underlines one of such perspectives. 



\section{Introduction}

José Manuel Leite Viegas, Helena Carreiras, and Andrés Malamud

This book is the result of several research projects carried out at CIES-ISCTE in recent years. Although its chapters cover a wide range of topics and methodologies, they also share common references. Most of them propose a diachronic analysis with periods delimited by key milestones such as the transition to democracy on 25 April 1974, the decolonisation process, and Portugal's accession to the European Communities. In some cases, social changes have taken place at slow pace: the generalisation of education, growing levels of social protection, and qualitative changes in public policies. In other cases the changes have been surprisingly fast, such as Portugal's transition from a country only of emigrants to one of immigration also. The chapters are not limited to Portugal as a case study. Most of them analyse new questions from a comparative perspective that involve other European countries.

Given the diversity of topics covered, and for the purpose of articulated reading, the chapters have been divided into three parts. The first one addresses institutions, identities and behaviour in the political sphere, dealing with fundamental questions such as parliaments, left and right identities and political behaviour. The second part deals with public policies and focuses on employment, social security, education, immigration and the armed forces. The third part addresses political issues from the point of view of representations and social relations.

In chapter 1, Andrés Malamud and Luís de Sousa conduct a comparative analysis of a relatively new phenomenon in the global scenario, supranational parliaments. After the experience of the European Union, whose parliament was elected by the people for the first time in 1979, other groups of countries set up and tried to consolidate parliamentary institutions to legitimise their integration processes. Most of these experiments have taken place in Latin America. This work makes a comparative analysis of five regional parliaments in Europe and Latin America - the European Parliament, the Latin-American 
Parliament, the Central American Parliament, the Andean Parliament and the Mercosur Parliament, in order to understand the impact that they have had on regional representation, decision-making processes and increased accountability. The chapter is divided into five parts, each on one of the regional parliaments. It is an analysis of the historical and political development of these bodies and examines their structure, powers and mode of operation in light of four classic parliamentary functions - representation (legitimisation, legislation (decision making), control of the executive and state apparatus (supervision) and formation of elites and political leadership (recruitment and training). The article ends with comparative conclusions.

Taking into account the importance of left-right positioning to the political orientation of European voters, the chapter by André Freire analyses the extent and evolution of their ideological identities from 1976 to 2002. In addition to testing the validity of controversial theories such as the "end of ideologies", the study also analyses to what extent voters' left-right orientations are subject to the influence of circumstances. It also looks into whether there are systematic differences between the new southern European democracies (Portugal, Spain and Greece) and the old polyarchies of western Europe. Considering that the formation of ideological identities depends on the socialisation of individuals in an environment of effective political and ideological competition, it inquires about the existence of systematic differences between new and old democracies. The conclusions show that, on the one hand, the stability of left-right orientations in the electorate is a factor that differentiates the new southern European democracies from the rest of western Europe. In the new polyarchies, some time has to elapse before reaching the level of recognition of ideological categories found in older systems. On the other hand, it is sustained that left or right orientations are not as consolidated in the new as in the older regimes.

The chapter by José Manuel Leite Viegas and Sérgio Faria compares political participation in Portugal and in other countries. This work is based on a survey conducted in a number of European countries as part of international research on citizenship and political involvement. Eight of the twelve European countries in the survey were selected for this analysis not only on the basis of geographical criteria but also because they represented different socio-cultural realities. These were the Scandinavian countries Sweden and Denmark, the Netherlands and West Germany in central western Europe, Portugal and Spain from the south and Moldavia and Romania in eastern Europe. The research has shown that political participation figures are relatively low in Portugal, in many cases higher only than those in eastern European countries. However, this overview does not take into account specific differences in participation in Portugal when compared to other European countries which can be found when the analysis focuses on each form of participation. For example, involvement in associations that are not strictly political is 
relatively high in Portugal, only lower than the Netherlands and Denmark. This shows that participation in Portugal has more limited impact on the public political sphere than is the case in developed European countries, but, it has a strong dimension of social and political integration.

The chapters in Part II analyse public policies on employment and social security, education, immigration and the armed forces. In the chapter "Social development policies: employment and social security", Luís Capucha, Elsa Pegado and Sandra Palma Saleiro analyse the evolution of employment and social security policies in five periods. The first went from 25 April 1975 to November 1975, which they define as the "revolutionary foundation" of the embryonic welfare state, the second from 1976 to 1986, characterised by reforms preparing for accession to the European Union, the third from 1986 to the mid-1990s, a period of expansion and growth in social policies, the fourth from the mid-1990s to 2001, characterised by a "recalibration of the European social model" and the implementation of active social policies and the last from 2001 to the present day, a period marked by neo-liberal social reforms, which the authors do not analyse. The analysis focuses predominantly on the fourth period, in which, according to the authors, a "new generation of active social policies" began. The strategic orientation towards the social area now gave priority to the prevention of unemployment, especially long-term, and the promotion of the reinsertion of excluded young people. This explains the importance lent to education and vocational qualifications, which resulted in the creation of pre-schools, vocational training for the unemployed, lifelong learning and the foundation of centres for the recognition, validation and certification of competences. The chapter ends with "Challenges for the future", which points out some of the country's greatest social and economic weaknesses. These are the structure of its economic sectors, with a predominance of activities with low technological investment, insufficiencies and backwardness in education and vocational training, innovation, investment in science and technology, and the continued existence of social segments or sectors that still live in poverty, in spite of the investment already made in this area.

In the chapter "The democratisation of school education in Portugal", João Sebastião and Sónia Vladimira Correia analyse what they call the massification and democratisation of education in recent decades. They begin with a paradox. Criticism of the education system has been strong in the last few years, precisely when universal nine years of schooling have been introduced. Critics accuse the state education system of severe deterioration and a drop in competences acquired at school. In order to answer these and other questions, the authors analyse data on educational qualifications in Portugal in the last three decades. They begin with an analysis of the illiteracy rate and the level of schooling of the resident population. There was a substantial reduction in illiteracy to $12.5 \%$ by 2001 . There has also been an improvement in educational qualifications in the last thirty years in basic [ $9^{\text {th }}$ 
grade], secondary and even higher education. These overall positive results are held up against international comparative studies, in which Portugal's results are disappointing in terms of competences acquired at school, where it is in $26^{\text {th }}$ place at the OECD. The authors then study the results from the point of view of democratisation of education, first analysing regional discrepancies and then returning to the old question of the role of the school in reproducing social inequalities. They then describe what they feel are imperatives for the future in education. The generalisation of nine years of schooling should be followed by greater attention to social disparities, both regional and those resulting from social selection. The authors believe that the principles of equality and democratisation of education should prevail over the trend towards a return to elite schooling.

In the chapter "Immigration policies in Portugal", Rui Pena Pires and Filipa Pinho first provide essential information on immigration after 25 April 1974 and then analyse nationality and immigration policies. When studying this issue, we must first take into account the profound changes that occurred in Portugal after 25 April 1974, clearly shown by the 400,000 foreigners with residence permits at the beginning of the $21^{\text {st }}$ century. Where immigration flows are concerned, the authors recognise three periods, "immigration from Africa after decolonisation, the 1980s and 1990s, marked by growth and diversification of migratory flows, and the turn of the century, a period of new migration from eastern Europe and Brazil". They then analyse the changes in the laws on nationality. It is a question of understanding how, after 25 April 1974 and due to the problem of people returning from the former colonies, Portugal abandoned its nationality policy based on ius solis for a mixed law with predominance of ius sanguinis. Legislation from 1981 and 1994 continued the restrictions on acquisition of Portuguese nationality from the first phase, in which immigration was regarded as a problem. In 2005, for the first time since 25 April 1974, the socialist government changed nationality policies, veering towards the principle of ius solis. On the subject of immigration policies, the authors first stress the absence of explicit references to this issue in government programmes before 1995. "The interpretation of immigration as a threat, a disturbing, largely undesirable phenomenon predominates". After that, new orientations appeared, such as the legalisation of illegal foreigners living in the country and a series of laws pertaining to the problem of integration, instead of focusing exclusively on the regulation of immigrant flows, as before. In the conclusion, the authors criticise restrictive policies concentrating on controlling migratory flows and reducing the rights of non-nationals, and point out their harmful effects, moving on to defend an immigration policy aimed at integration of non-nationals.

In the chapter "The Portuguese armed forces: changes and continuities at the turn of the millennium", Helena Carreiras looks at the situation of the Portuguese armed forces in the context of major changes in military 
organisation patterns and civil-military relations which have been affecting western countries in recent decades. Taking the analytical model of Moskos, Williams and Segal (2000) as a starting point, she observes the way the Portuguese Armed Forces are positioned regarding some of the variables of this model: strategic orientation (definition of missions and perception of threats); organisation (type of recruitment, structure of forces and socio-professional identities); public attitudes towards the military and patterns of gender integration. The analysis suggests that there are opposite forces at work, between the modernising and conservative poles, producing effects both in structural and cultural terms.

Part III is a little more heterogeneous than the others, in that it contains more clearly distinguishable chapters, both in terms of goals and perspectives of analysis. However, in all of them, the analysis of institutions and social processes in the areas of health, the prison system and social relations in companies, is closely articulated with the question of their social representations in the field of symbolic production.

In "Health and risk in Portuguese society", Graça Carapinheiro conducts a sociological analysis of health and stresses the way in which a series of new assumptions regarding how to address health and sickness, revolving around the emergence of categories such as "social construction of health and sickness" or "patient status", have been incorporated and/or critically assessed in new sociological research agendas on health and in empirical studies conducted in Portugal in recent years. In order to sketch the contours of this epistemology, the author suggests a relationship between health and society that helps re-launch the politicisation of health issues. Looking at practices and representations on health from the point of view of the concept of social risk, she reviews several studies conducted in Portugal on subjects such as medically assisted reproduction, self-medication, the genetic risk of hereditary cancer and medical technocracies. Her analysis of the different risk regimes seems to suggest the hypothesis with which she ends her articles that "the closer we come to institutional health contexts, the greater the social selection nature of the biomedical risk discourse, and the closer we come to everyday health practices, the greater the biomedical nature of the social risk discourse in reciprocal processes of endogenisation of cultures".

The concept of risk is also a strong reference in the chapter entitled "Penitentiary risk and prohibitionist spirit", in which António Pedro Dores reviews a series of questions related to prison models and penal policies in Portugal. Basing his premises on authors such as Loic Wacqant, Reich and Castells, the author studies the relation between the "penal state" and the "prohibitionist spirit" and questions the effectiveness of the dominant institutional model in Portugal. Taking an openly critical attitude, Dores punctuates his thoughts with empirical information on the functioning and characteristics of the prison system in Portugal. He also includes international comparisons 
in his analysis, particularly with Europe and the United States. In his opinion, "It is up to sociology to produce information not only on the practical risks of the dominant social configuration that has become a penal state but also on diagnoses pointing to therapeutic ways of facing these risks, which will be able to prevent the penal state and the susceptibility to political scenes covering up the causes of the social malaise". His conclusion speaks of the need for a "preventive sociology".

Finally, in the chapter "Company-level labour relations and the industrial relations system in Portugal", Alan Stoleroff addresses labour relations in Portuguese companies. The author describes an opposition between bilateral and unilateral forms of regulating labour relations and seeks to verify the presence and degree of mutual recognition between the players inside companies and the efficacy of forms of regulation established at supra-corporate level (articulation between meso and micro levels). Based on data from two surveys of Portuguese companies in 1994 and 2003, he portrays some of the basic characteristics of labour relations there using union membership and negotiation practices as central indicators. The idea is to take stock of this component of the industrial relations "system" and ascertain the effects that this empirical portrait may have on the system's design. He makes an empirical identification of the presence (and absence) of unions at companies, the existence or lack of contact and negotiation by the company with existing unions and compliance with collective agreements at higher levels or management acts that get around the implementation of these agreements. He also looks at the extent to which companies have human resource management practices that seek to individualise workers's behaviour or aspects of hiring. In his conclusion, Stoleroff maintains that the results show a division in employment regulations in Portugal at companies and organisations between a trade union and non-trade union sector, arguing that, due to this division, the paradigm of industrial relation systems loses its pertinence.

Whether more broadly or in a more focused way, all the chapters in this volume take stock of major trends in the development of the processes, institutions and policies under analysis. Together with theoretical interpretations and analyses of empirical information about Portugal, they also review the way in which social sciences in general and sociology in particular have been looking at these issues. As they associate the concern for a diachronic approach with an emphasis on comparison, they will constitute important contributions to deeper, more accurate knowledge of Portuguese institutions and policies in the European and international contexts.

By giving us a better understanding of the socio-political dynamics of the present and recent past, the chapters in this book provide elements for looking at the future. In different ways, all the authors leave questions, clues or draw scenarios in light of which future research agendas can be defined. This is also one of the important goals of the collective work that CIES wished to see reflected in the chapters in this volume. 
Part I INSTITUTIONS, IDEOLOGIES AND POLITICAL BEHAVIOURS 



\title{
Supranational parliaments in Europe and Latin America Between empowerment and irrelevance
}

\author{
Andrés Malamud and Luís de Sousa
}

\section{Introduction}

After four centuries of gradual development, the modern parliament was born in England in the $17^{\text {th }}$ century as an instrument by which the rising bourgeoisie could control the monarchy. It claimed legislative supremacy, full authority over taxation and expenditure, and a voice in public policy through partial control (exercised by impeachment) over the king's choice of ministers. It later spread to America - becoming a separate branch of power then to continental Europe and subsequently to the rest of the world, becoming the emblematic institution for political deliberation and legislative decision-making in modern nation-states (Orlandi, 1998). Parliaments, or analogous legislative assemblies, were also established in several subnational units such as states or provinces, some of which were originally autonomous but later united into federal nation-states. Subnational parliaments date back at least as far as the $18^{\text {th }}$ century, being present in the American colonies when independence was declared and the Constitution established. Supranational parliaments, in contrast, are a much more recent phenomenon.

The first significant supranational parliament was the European Parliament which, in the words of the 1957 Treaty of Rome, "represents the peoples of the States brought together in the European Community." The Parliament's first direct elections were held in June 1979; since then, it has derived its legitimacy from direct universal suffrage and has been elected every five years. Other processes of regional integration have attempted to replicate such a supranational legislative assembly, Latin America being the region where these experiments have gone the farthest. In November 2005, membership of the Inter-Parliamentary Union (IPU) accounted for 143 national members and seven associate members, all of the latter having an international nature: the European Parliament, the Parliamentary Assembly of the Council of Europe, the Andean Parliament, the Central American Parliament, 
the Latin American Parliament, the East African Legislative Assembly, and the Parliament of the Economic Community of West African States.

This phenomenon raises some questions. First, why should region-makers take the trouble to establish a regional parliament (Rittberger, 2003) when integration is first of all an economic endeavour? Second, are regional parliaments real parliaments, or do they fall short? Third, how are these parliaments different, especially regarding those that have taken root in Europe and Latin America? ${ }^{1}$ This article addresses these questions through a comparative analysis of five regional - also called supranational - parliaments. It includes all the Latin American cases mentioned plus the recently created Mercosur Parliament and the European Parliament. Some bodies are excluded from this comparison: the Parliamentary Assembly of the Council of Europe is not discussed since it has no ambition to develop any further, and the African cases are too young to be evaluated.

This article proceeds as follows. Each of the first five sections analyse one parliamentary assembly in order to summarise its historical evolution, examine its structure and assess its competences and performance in light of the classical parliamentary functions. These functions are fourfold: representation (related to input legitimacy), legislation/decision-making (output legitimacy), monitoring of the executive branch and the bureaucracy (control legitimacy), and leadership selection and formation - which, as Weber (1994) argued, is essential to democracy. The last section elaborates a handful of comparative conclusions.

\section{The European Parliament (EP)}

Anyone looking for the first time at the institutional fabric of Europe is likely to be surprised by the numerous arrangements that overlap, interact and cooperate to make this a unique case of regional integration. Due to the level of integration reached between its members and the scope and intensity of its policy competencies, the EP has become the core organisational structure in Europe. There is, however, a series of other organisations, established prior to the 1957 Rome Treaties, whose contributions to the singularity of the European integration process has been noteworthy - albeit less wide-ranging and encompassing fewer decisional competencies. Some of these international organisations have survived independently of the European integration process, even if they have retained only a symbolic or deliberative role (for example, the Council of Europe) or have later been incorporated into groups involved in the European treaties (for instance, the Western European Union).

1 The two African parliaments are newer and less developed than the rest, and they only joined the IPU in 2005. 


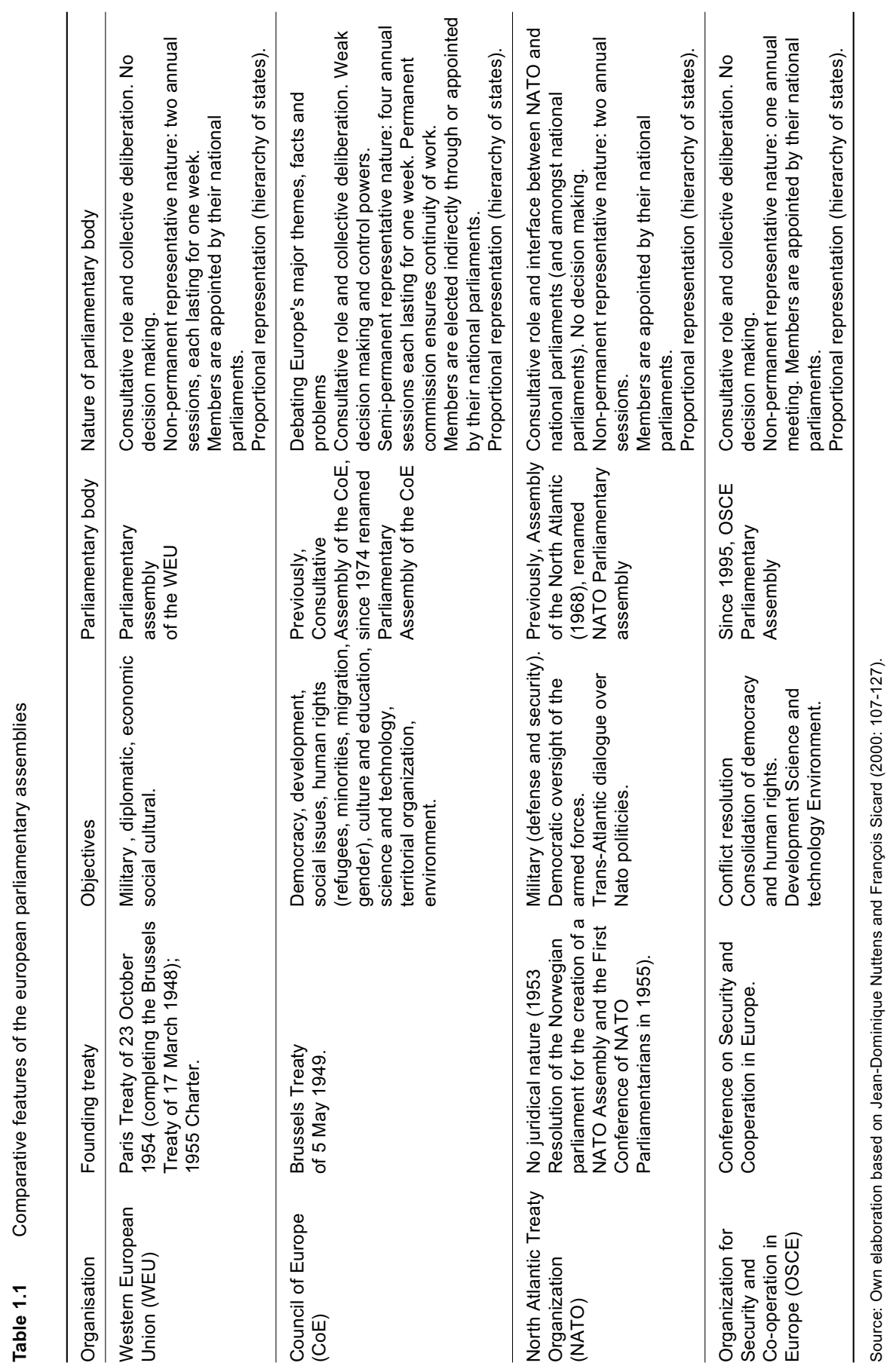


Some organisations have limited their membership to European nations (e.g., the OSCE); others, such as the OECD, have extended their activities to other countries and regions of the world. However, one common feature of most of these organisations is the existence of a parliamentary assembly (table 1.1).

One could also mention other parliamentary initiatives such as the Nordic Council (which includes representatives from the Scandinavian parliaments), the Benelux Inter-parliamentary Consultation Council, the Baltic Assembly, the Black Sea Parliamentary Assembly for Economic Cooperation and the Parliamentary Conference of Central European initiative. None of these extra-EU bodies have, however, played a similar role to the European Parliament (EP) with regard to the European integration process, nor do they enjoy comparable competencies. Of all the regional parliamentary bodies, the EP is the only one that has developed real decision-making powers and become a central component of the complex decision-making structure of the European Union. In order to understand how the EP has evolved from merely another parliamentary assembly into the foremost one, it is useful to review the structures and processes of the European Community.

\section{Evolution and competencies of the European Parliament}

The founding fathers of the 1951 Treaty of Paris (ECSC) sought a rupture with the past. The failure of the Council of Europe as an institutional response to the idea of a united Europe was a clear example of what the ex-members of the Council, such as Paul-Henri Spaak, wanted to avoid in their new project (Urwin, 1997: 78). Their ambitious project was based upon an institutional compromise between intergovernmental and supranational decision-making and a tripartite liberal constitutional framework: an executive that initiated and implemented policies; an assembly in which those policies were debated and decided upon; and an independent judicial body whose members reviewed decisions and settled conflicts.

The originality of this regime lay in the translation of the traditional tripartite division of powers - executive, legislative and judicial - into an international institutional arrangement which combined intergovernmental and supranational decision making. The competencies of the three major political bodies - the Commission, the Council of Ministers and the European Parliament - were intertwined to the extent that a clear-cut division of the executive and legislative powers was, and remains, difficult to establish.

Two institutions share the executive function: the European Commission and the Council of Ministers. The European Commission is a supranational body appointed through common agreement between the member states, but which is independent from their respective governments. The Commission represents the interests of the community, acts as "guardian of the Treaties" (by ensuring that treaties and Community law are respected, even if this 
means bringing a member state before the ECJ), and remains the hub of the decision-making system (Mény, 1998: 24). The Council of Ministers is an intergovernmental body composed of representatives of the member states, which embodies their interests.

Although these two bodies are termed executive organs, they also carry out legislative functions. The Commission has a near monopoly on initiating legislative proposals within the community and is responsible for managing existing common policies and monitoring the application of Community law. It can also make decisions (autonomously or upon delegation from the Council), give its opinion and make recommendations. The Council has broad decision-making powers: it may pass regulations and directives, conclude agreements and treaties (which are negotiated with the Commission), and share budgetary powers with the Parliament.

The EP, like the national parliaments of all EU member states, is elected by universal suffrage; however, unlike most European parliamentary regimes, the "European government" does not emanate from any majority represented in the EP. In other words, election to the EP is not intended as a reward or punishment for a "European executive", even if the EP has the right to dismiss the Commission in a vote of censure by a two-thirds majority. The EP also has supervisory powers over EU bureaucrats and agencies, and decides on the adoption of legislation together with the Council of Ministers by means of the codecision procedure. The EP can install inquiry commissions, question Commissioners on any issue relating to a common policy, pass resolutions, and hold hearings. However, limited legislative powers and the inability of voters to choose their European executive at the ballot box may partly explain the low turnout at European elections and the tendency of national parties to use these elections to test national incumbent majorities. To this complex institutional triangle, as it is called, one should add the "decisional power" that emanates from the European Court of Justice's decisions (Mény, 1998: 25).

We should not forget that this decision-making structure operates within a complex and evolving balance between three sources of input legitimacy with competing interests: the interests and demands of the European people(s), represented in the EP by their MEPs and the Euro-parties; the interests of member states, as represented in the Council; and the community interests represented in the Commission and expressed by treaties, Community law and the jurisprudence of the ECJ.

\section{The empowerment of the European Parliament}

Initially, the role of the EP was similar to that of the Council of Europe parliamentary assembly with regard to the scope of its competencies and its 
institutional design. The EP, known as "the assembly" until $1962,{ }^{2}$ was essentially a forum composed of delegations appointed from the national parliaments. It had a limited consultative function regarding a small number of issues and legislative proposals prior to their adoption by the Council. The founding fathers did not provide the EP with a central role in the European integration process from the outset. Instead, its competences evolved over time mostly due to institutional mimesis (Costa, 2001: 19).

The creation and institutional set-up of the EP was in line with a pattern of institutional design common to all post-1945 occidental regional and international organisations. The majority of these organisations had a similar decision-making structure: a council where decisions were made and a consultative assembly of a more or less permanently representative nature (i.e. UN, WEU, Council of Europe and NATO). The symbolic dimension attached to this type of parliamentary institution was also crucial. These assemblies served not only as an interface between the organisation and its national members, but they also made it possible for the political elites of countries that had been at war with each other to be in close contact, and hence the assembly helped to restore the mutual trust and cooperation between old adversaries. Furthermore, in a Cold War context they also sent out the message that the West "does it better".

However, there was another important factor involved: the pooling of sovereignty. The idea of building a political project beyond the nation-state, which both Robert Schuman and Jean Monnet had in mind, raised problems of legitimacy and accountability, since it challenged the traditional concept of territorial sovereignty. It was inevitable that the supranational political project would need to include some sort of plenary assembly where the different views, positions and ideas of its members could be expressed and where the decisions made on a much more restricted level for the totality of members could be subject to collective scrutiny and, possibly, majority deliberation. It was too early to talk about a parliament of European people(s) as part of a copy-paste version of national democracies transplanted to the regional level, an idea that had always displeased some European countries (such as the UK). Instead, the founding fathers counted on the ability of such a parliamentary institution to ensure the efficacy and legitimacy of the activities of the supranational High Authority created for the European Coal and Steel Community.

Which factors have contributed to the evolution of the EP from simply "another international parliamentary assembly" into a unique supranational parliament with real decisional powers and a central role in the process of European integration? The answer is not straightforward, but three factors are

2 The 1986 Single European Act would finally formalise the denomination of European Parliament. 
worth mentioning: early supranationalism, extraordinary leadership and direct elections. Let us develop these further.

First, the institutionalisation of the EU evolved from a single objective and supranationally oriented organisation - the European Coal and Steel Community - whereas other European international organisations, such as the Council of Europe, were created with the purpose of addressing multiple and diffuse objectives and were always kept intergovernmental. The latter organisations have affected the lives of Europeans, but none of them have had enough strength or vocation to lead to the creation of a supranational structure. The supranational regulation of the production of coal and steel, the raw materials of war and industry and sources of energy, represented a small policy step to countries that had been at war with each other, but it would prove to be a giant leap in the European integration process.

Second, the leaders behind the venture of European integration had common experiences and a common vision. Monnet, Schuman and Spaak had served the Council of Europe project, but later abandoned it in reaction to British euro-scepticism and reluctance to move towards supranational forms of government, even though this only concerned the regulation of a single industrial or commercial sector. Their views were backed by a small number of countries - the Six - that had decided to expand the "community method" into other economic and social policy areas. Each of these countries had strong reasons to believe in the process of European economic integration: Benelux had already implemented a successful customs area; the running of the High Authority had promoted a lasting Franco-German understanding; and in Italy an important federalist movement had been born.

Third, the direct election of the European parliament in 1979 and the subsequent emergence of Euro-party formations were the turning point for the role this body would play in the triangular institutional complex of the EC and in the integration process itself (Corbett, 1998). Since then, the EP has been elected by the European peoples every five years, according to a distribution of seats that roughly reflects the demographic weight of each state (tables 1.2 and 1.3). A system of proportional representation for EP elections, which had already been in place in most member states since 1979, has been used by all member states since the 1999 elections. The electoral dynamics, together with the progressive empowerment granted by each successive treaty reform and the spillover effects of qualified majority voting in the Council, transformed the EP into the only supranational parliamentary assembly in the world that enjoys simultaneous democratic legitimacy, decision-making competencies and the power to bring down a "government" (the Commission). In it, European parliamentarians have the chance of honing their political skills in an influential, supranational environment - even if they are frequently recruited from the ranks of elder politicians or party dissidents, either as a golden parachute for retirement or as a mutually convenient arrangement to take out 
Table 1.2 European parliament: seats per country (in alphabetical order according to the country's name in its own language)

\begin{tabular}{lccc}
\hline & $1999-2004$ & $2004-2007$ & $2007-2009$ \\
\hline Belgium & 25 & 24 & 24 \\
Bulgaria & - & - & 18 \\
Cyprus & - & 6 & 6 \\
Czech Republic & - & 24 & 24 \\
Denmark & 16 & 14 & 14 \\
Germany & 99 & 99 & 99 \\
Greece & 25 & 24 & 24 \\
Spain & 64 & 54 & 54 \\
Estonia & - & 6 & 78 \\
France & 87 & 78 & 24 \\
Hungary & - & 24 & 13 \\
Ireland & 15 & 13 & 78 \\
Italy & 87 & 78 & 9 \\
Latvia & - & 9 & 13 \\
Lithuania & - & 13 & 6 \\
Luxembourg & 6 & 6 & 5 \\
Malta & - & 5 & 27 \\
Netherlands & 31 & 27 & 18 \\
Austria & 21 & 18 & 54 \\
Poland & - & 54 & 24 \\
Portugal & 24 & 36 \\
Romania & -- & 14 \\
Slovakia & - & 7 & 7 \\
Slovenia & - & 7 & 14 \\
Finland & - & 14 & 19 \\
Sweden & -- & 19 & 78 \\
United Kingdom & 16 & 78 & 786 \\
\hline (MAX) TOTAL & 22 & 732 & \\
\hline
\end{tabular}

Source: http: //www.europa.eu.int/institutions/parliament/index_en.htm (26 August 2004).

internal opponents (Bardi, 1996; Scarrow, 1997). The evolution of the EP over fifty years is elegantly synthesised by Hix, Raunio and Scully (2003: 191-2):

For much of the half-century since its humble beginnings, the European Parliament... was marginal to the development of European integration and the politics of the European Union. Initially, the institution was essentially a consultative body composed of delegates of national parliaments. Fifty years on, the elected Parliament has significant legislative and executive investiture/removal powers and all the trappings of a democratic parliament that flow from such powers: powerful party organisations, highly-organised committees, a supporting bureaucracy and constant lobbying from private interest groups.

From a European perspective, the EP may still be a developing body with many shortcomings; from the perspective of an outsider, however, the EP is the archetype to which every supranational parliament will be compared to for years to come. Moreover, it has become the standard model for those who would 


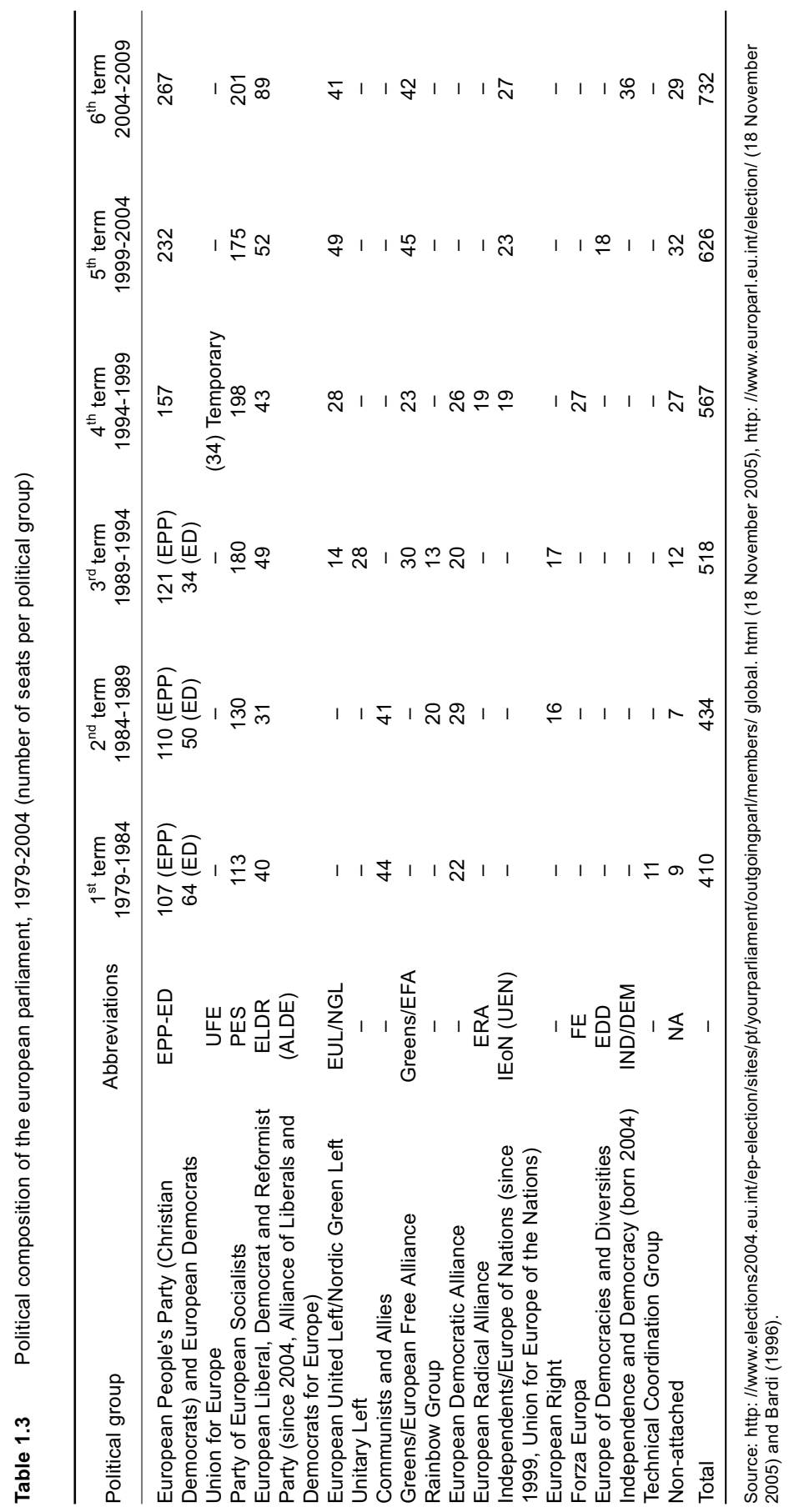


undertake the mission of institutionalising regional integration elsewhere. Thus far, Latin America is the region where its influence has proved the strongest.

\section{The Latin American Parliament (Parlatino)}

The Latin American Parliament is a regional, unicameral assembly made up of members of twenty-two national parliaments of Latin America and the Caribbean. ${ }^{3}$ Founded in Lima, Peru, in December 1964, it was later institutionalised by an international treaty signed in Lima in November 1987. Between 1992 and 2008 it was located in the Brazilian city of Sao Paulo, and then it was moved to Panama City. Its main goals, as stated in its charter, are the defence of democracy, the promotion of regional integration and the strengthening of cooperation among parliamentarians and parliaments across Latin America. It has legal personality and a budget provided by the signatory states. Its official languages are Spanish and Portuguese.

The Parlatino assembly is composed of national delegations sent by the member parliaments. Each national delegation may appoint up to twelve representatives in a proportion that reflects the weight of the national parliamentary groupings. If a delegation has less than twelve members, each of them can cast up to four votes without exceeding the overall number of twelve; this disposition grants all countries the same voting power regardless of country size. A quorum is obtained when more than half the national delegations are present, provided that their delegates represent at least one third of the overall votes. Parlatino gathers once a year in its permanent location. It has no decisional authority and limits itself to passing agreements, recommendations and resolutions that are not binding upon any other body or organisation.

One puzzling characteristic of Parlatino is that its membership does not include Haiti (only independent French-speaking state in the Americas) or the French overseas departments (French Guyana, Guadeloupe and Martinique). However, despite the "latino" component of its name, the organisation does include three Dutch-speaking members: one independent country (Suriname) and two dependencies of the Kingdom of the Netherlands (Aruba and the Netherlands Antilles).

Due to its open, malleable and extended territorial scope, Parlatino resembles the Parliamentary Assembly of the Council of Europe more than the European Parliament; it is also similar to the former institution in its

3 The signatory countries are Argentina, Aruba, Bolivia, Brazil, Chile, Colombia, Costa Rica, Cuba, The Dominican Republic, Ecuador, El Salvador, Guatemala, Honduras, Mexico, the Netherlands Antilles, Nicaragua, Panama, Paraguay, Peru, Suriname, Uruguay and Venezuela. 
intergovernmental nature and lack of powers. However, as will be seen below, these are common characteristics for most regional assemblies in Latin America. Unlike the other regional assemblies analysed in this article, though, Parlatino is not the representative, deliberative or decisional body of any regional organisation, but has rather had an independent status since its very inception. This characteristic is unique, as parliaments are generally institutions which belong to some wider encompassing entity.

Parlatino has gained a certain international recognition notwithstanding its limited influence and competencies. In 1972, it agreed with the European Parliament - which at that time was also indirectly elected - to establish permanent contacts and convene a regular Inter-parliamentary Conference. The first was held in Bogotá in 1974, and since 1975 they have taken place every two years without exception, the venue alternating between a Latin American country and a European Union member state. To date, sixteen such events have been organised, making the conference the longest running bi-regional forum. The debates and resolutions produced as a result of the conferences have constituted a testimony to the dominant issues of the trans-Atlantic agenda, as well as to the evolution and shortcomings of the Conference. The salience of this forum decreased with the consolidation of democracy in Latin America, as most national parliaments saw their continuity guaranteed. When the Inter-parliamentary Conference's long fight for representative institutions and the defence of human rights had finally been won, the Conference failed to find another equally mobilising issue and its prominence slowly declined. The new focus on institutional quality and the reform of public administration has proved less attractive, and the cause of regional integration has found better supporters in the sub-regional blocs that were created or relaunched in the early 1990s.

Despite a general agreement regarding the main issues on the common agenda, there have been some topics that have revealed persistent asymmetries between the two regions. In particular, significant consensus has never been reached on matters concerning international trade and foreign debt. In a different vein, cooperation for development is one area that brings to light the structural imbalances between the two regions, but it has never evolved into a controversial matter since its management depends on the unilateral will of the wealthiest party - the European Union.

In sum, Parlatino is a symbolic rather than an operative body, capable of hosting deliberation on regional and inter-regional affairs but with no prospect of ever becoming a decisional organ. It lacks both political significance and social roots. Its main historical merits have been to provide a beacon for democratic aspirations and parliamentary procedures during the dark era of Latin American dictatorships; its main shortcomings have possibly originated in its not belonging to any significant, more encompassing organisation. 


\section{The Central American Parliament (Parlacen)}

The Central American Parliament is the deliberative body of the Central American Integration System (SICA). Building upon the Central American Common Market, founded in 1960, the SICA was established in 1991 as a complex organisation linking the Central American countries on a variable geometry basis. Hence, while SICA brings together the seven Central American countries (Belize, Costa Rica, El Salvador, Guatemala, Honduras, Nicaragua and Panama), the Parlacen excludes two of them (Costa Rica and Belize) but includes the Spanish-speaking, Caribbean state of the Dominican Republic. SICA also features a supranational judicial branch, the Central American Court of Justice, and an intergovernmental supreme authority, the Central American Presidential Meetings. The function of Secretary General exists to coordinate the whole system. Parlacen is broadly considered to be the parliamentary organ of SICA, although, as will be seen below, it has not developed any legislative function.

Parlacen was first envisaged in the Declaration of Esquipulas I, which was signed by the Central American presidents with a view to putting an end to traditional rivalries and foster democracy and peace in the region. The presidential summit, strongly supported by the Contadora Group, its Group of Support ${ }^{4}$ and the then European Community, took place in May 1986. In a later Declaration known as Esquipulas II, made in 1987, the presidents agreed that the Parliament should be the symbol of freedom, independence and reconciliation for the region, which had been devastated after years of bloodshed and political instability. Between the end of 1987 and early 1989, Guatemala, El Salvador, Costa Rica, Nicaragua and Honduras successively signed and ratified the Parlacen Constitutive Treaty. Three additional protocols were signed afterwards in order to allow for the delay in the election of the national representatives and to facilitate the adhesion of Panama to the Treaty - although its incorporation would only be fully complete in 1999. The Parliament was finally established in October 1991 when its assembly first met in Guatemala City, which would become its permanent location. Costa Rica eventually declined to participate, while the Dominican Republic joined the process in 1999.

Since October 28, 1991, Parlacen has grown from having a total membership of 65 deputies, representing four countries and 13 political parties, to

4 The Contadora Group, founded in 1983, was made up of Mexico, Colombia, Venezuela and Panama, whereas its Group of Support, established in 1985, was made up of Argentina, Uruguay, Brazil and Peru. The goals of both groups were to contribute to a negotiated solution to the Central American conflict, and their principles included self-determination, non-intervention, demilitarisation and democratisation. In 1986 the two groups merged into what came to be known as Grupo de Rio. 
the current total of 132 deputies, representing six countries and 42 parties. The deputies are directly elected every five years by the people of the member countries, each country having the right to elect 20 representatives. In addition, each country has the right to send two appointed deputies, namely their former presidents and vice-presidents. On top of the full member countries, other parliaments send representatives with observer status: among them, Parlatino, the Andean Parliament and the European Parliament have participated since the beginning of the process, whereas Puerto Rico, Mexico and Taiwan entered at a later stage. The national representations are clustered in three broad parliamentary groups: the largest one represents the center of the political spectrum, while the other two cover the left and right wings.

As acknowledged by the first article of its founding treaty, the legislative competencies of Parlacen are limited to proposal, analysis and recommendation. However, the treaty also confers it with the ability to elect, appoint and remove the highest executive official of all the institutions that belong to the SICA. Strangely enough, this parliamentary organ is not able to pass laws but it is (formally) empowered to nominate and hold accountable a myriad of technical administrators (article 5c). It is also allowed to request information and reports from every SICA organ and to make recommendations to them, but not to interfere in their functioning. As for voting procedures, Parlacen makes decisions by absolute majority, except where establishing or amending internal statutes is concerned: in this case, a qualified majority is required. The country members provide for the parliamentary budget on an equal basis.

After more than a decade of operation, the record of Parlacen is mixed: while it can boast sound achievements in enlarging its membership, it has made no progress regarding the deepening of its competencies. If, on the one hand, it has effectively contributed to pacification and growing interdependence among the societies it represents, it has at the same time failed to become a decisive actor in the feeble process of Central American integration.

\section{The Andean Parliament (Parlandino)}

The Andean Parliament is the deliberative organ of the Andean Integration System (AIS). The Andean Pact, ${ }^{5}$ precursor of the AIS, was founded in 1969 with the goal of overcoming the shortcomings of the Latin American Free Trade Association (ALALC), a wider regional project that had failed mainly because it had reproduced internally the division between more and less developed countries that it criticised in the world as a whole. The founders of the 
Andean Pact drew on the model of integration that was then being consolidated in Europe, and so they decided to formalise the process of integration by creating a network of institutions that included majority voting and binding supranational authorities. By the end of the 1980s, after years of turbulence and standstill due partly to domestic factors but also to the failure to foster economic interdependence, the national presidents decided to relaunch the process with more modest aspirations and a more frugal institutional design. However, the institutional structure of the organisation still bears a great resemblance to that of the European Union: it features a Commission, a Parliament, a Tribunal of Justice, a Council of Ministers and a Presidential Council, as well as a set of technical institutions such as financial corporations, consultative forums of the civil society and even a university. Nevertheless, the real competencies and performance of these regional institutions lags behind those of their European models.

Within the institutional arrangement described above, Parlandino is meant to represent the peoples of the Andean Community and enjoys a supranational nature. Its founding treaty was signed in 1979, coming into force in 1984. Its location is the Colombian city of Bogotá, and in 1997 it was decided that parliamentarians would be elected by popular vote. The electoral process was supposed to take place within the following five years; yet, at the time of this writing only two countries (Venezuela and Ecuador) have completed this process. In the remaining countries, direct elections are either planned for the near future (Colombia and Peru) or subject to a previous constitutional review (Bolivia).

Parlandino is made up of 25 deputies, five from each member country. There are five standing committees composed of five members each, one of each nationality. Parlandino is entitled to issue as many as four different kinds of acts (decisions, agreements, declarations and recommendations), all of which must be approved by an absolute majority. Parlandino lacks any decision-making competence. Its competencies are vague and limited to the following areas: steering and fostering the integration process; promoting the harmonisation of legislation between member countries; encouraging cooperation and coordination with the national parliaments, third countries and other integration associations; and formulating recommendations regarding the budget of the Andean Community.

In 2004, Parlandino celebrated its $25^{\text {th }}$ anniversary. It is half the age of the European Parliament, which has always been the model and source of inspiration for the founders of the Andean Community. The huge differences between the two assemblies, though, could not be more evident. Considering the delayed and irregular popular election of national representatives, a composition that is not demographically proportional, and the absence of decision-making attributions, Parlandino has evolved relatively little, just like the regional bloc to which it belongs (Bonilla, 2001; Malamud, 2004). Contradictory national 
interests, institutional instability, economic turmoil and even political conflict among the member countries have, in fact, rendered the Andean Community a textbook example of what to avoid when crafting an integration project. As key Argentine and Brazilian actors have emphasised, the first steps in the formation of Mercosur drew upon the experiences of the Andean region in order not to repeat the same pitfalls (Caputo, 1999; Pereira, 2000). ${ }^{6}$

\section{The Mercosur Parliament (Parlasur)}

Mercosur, a Spanish acronym that stands for Common Market of the South, was founded in 1991 by the Treaty of Asunción, and consolidated in 1994 by the Protocol of Ouro Preto. It brings together four countries: Argentina, Brazil, Paraguay and Uruguay, with Venezuela joining in 2007. It aims at creating a common market through the lifting of intra-regional obstacles to the circulation of goods, capital and services and has taken steps towards a freer circulation of people. Although its founding fathers had in mind the successful experience of the European Union, they were also aware of the poor record of integration in Latin America and attempted to minimise the risks of failure by avoiding premature institutionalisation, while keeping the control of the process in the hands of the national presidents (Malamud, 2003). Henceforth, Mercosur developed as an exclusively intergovernmental organisation: although its legal personality enables it to become involved in international negotiations on behalf of its members, internal unanimity is required in order to make any decision. National sovereignty has neither been delegated nor pooled, and all the decisional organs of Mercosur are exclusively composed of senior government officials from the member countries (Peña, 1998). However, there are also some non-decisional institutions worth considering, such as the Joint Parliamentary Commission.

The Joint Parliamentary Committee (JPC) was, until 2007, the organ of Mercosur that brought together the delegations of the four national congresses. The Treaty of Asunción, signed in March 1991, foresaw the JPC as a means of facilitating the creation of a common market. The means by which it would contribute to such an end was not clear, though, as the Treaty did not endorse it with any competence; instead, it mentioned the national executives' obligation to report to their respective congresses about the progress of the integration project.

It was the Protocol of Ouro Preto, signed in December of 1994, which established a stable design for the JPC, while at the same time defining the overall institutional structure of Mercosur. The JPC was transformed into the 
representative organ of the national parliaments - its main function, to contribute to the transposition of Mercosur procedures into the national legislation of the member countries. Additionally, it was expected to assist with policy harmonisation and perform the role of a consultative assistant to the Common Market Council, the supreme regional body made up of the foreign and economic ministers of the signatory countries (Caetano and Perina, 2000, 2003). The JPC should accomplish its duty through the elaboration of recommendations, dispositions and declarations, none of which were binding; it was also assigned the mission of paving the way for the creation of a full parliament of Mercosur.

The Protocol of Ouro Preto determined that the JPC would be constituted by a maximum of 64 members. Each country would elect up to sixteen representatives from active national lawmakers, including members of the two chambers (every Mercosur member country features a bicameral parliament). The representatives would be grouped into national sections that would comprise both deputies and senators. The moment and mechanism for election and the duration of the tenure would be defined by each national parliament, but the Protocol suggested a minimum term limit of two years in order to grant some continuity to intra-parliamentary labour.

The Protocol also established that the JPC would meet at least twice a year, but in order to be valid, a meeting would have to be attended by representatives from every state. Moreover, all the decisions of the JPC would have to be made by consensus, the same rule that applies to every body of Mercosur. These requirements led to a fully intergovernmental institution and contributed to the blurring of party differences and the neutralisation one of the main activities usually performed within a parliament, that of voting. The presidency of the JPC was not to be elected by the plenary but rotate among the member states every six months, just like the presidency of Mercosur as a whole. A Permanent Administrative Secretariat existed, but its office-holder, who was not a parliamentarian, was also appointed on a mandatory rotating basis involving the four countries - although this tenure lasted two years instead of six months.

The internal statute of the JPC addressed the possibility of creating committees, as long as they were not standing but ad hoc. This regulation did nothing to promote specialisation among the parliamentarians or to provide them with a stable career path or progressive training. As a rule, the JPC met in the country that held the temporary presidency. The budget of the JPC was provided for in equal parts by Mercosur member countries.

Since the mid-1990s or even earlier, an increasing number of voices from both politicians and academics - have demanded the creation and empowerment of a Mercosur parliament (Caetano and Pérez Antón, 2003; CEFIR, 1998; SM, 2004; Vazquez, 2001). However, only modest results have been achieved regarding a composition and a set of competences that are 
acceptable for all member countries. Given the marked demographic asymmetries within the bloc, this is a difficult puzzle to solve. Brazil has roughly $80 \%$ of the population of Mercosur, so any distribution under which it is allocated less than $50 \%$ of the seats could be perceived as undemocratically biased and would face resistance. On the other hand, giving Brazil more than $50 \%$ of seats would mean that it alone would hold a permanent majority. A compromise could be reached by conceding a majority to either party but, simultaneously, stripping that majority of any real power - either by requiring decisions to be made by "super majority" or by denying the parliament any significant competences at all. The former option would diminish democratic legitimacy, while the latter would neutralise effective decision making (Malamud, 2005b).

An agreement was finally struck in December 2005, when the Mercosur Council decided to set up the Parliament of Mercosur. It was located in Montevideo and its installation should be processed along two transitional periods. In the first one, a body similar to the JPC (the only difference being that every country would send 18 instead of 16 parliamentarians) replaced its institutional ancestor. In the second period, direct elections were mandated to take place in 2011. The first regular elections after the transition are to be held simultaneously in all member countries in 2014. The decision, however, stopped short of prescribing the final composition of the body. Its competences, on the other hand, were clearly determined: legislating was not among them. ${ }^{7}$

\section{Comparative analysis}

Of all the international institutions either known as parliaments or designed in such a way as to resemble them closely, only the European Parliament has developed a truly supranational character and been allowed to hold effective power thus far. The others lag far behind in all respects (Vieira Posada, 2000). The history, structure, competencies and functions of these institutions vary widely, as does the degree of legitimacy they enjoy. This chapter has presented an analysis of regional parliaments in order, on the one hand, to homogenise the conceptual field and, on the other, to present a comparative state of the arts.

After examining five regional parliamentary bodies in two continents, the differences between the European Parliament and the four Latin American proto-parliaments are striking - whatever the characteristic considered. Table 1.4 presents a stylised comparison of the five cases.

7 The exhaustive list of competences includes: to watch over, to elaborate (reports), to request (information), to invite, to receive, to hold (meetings), to examine, to convey, to issue (declarations and recommendations), to propose (studies and projects), to develop (actions), to maintain (institutional relations), to celebrate (agreements) and to foment (values). 
As far as representation is concerned, only one Latin American parliament, Parlacen, appoints the majority of its members through popular direct elections. However, there is no demographic proportionality among the constituencies (that is, the member countries). Input legitimacy is poorly served by any parliament that is neither elected by nor accountable before the citizens. With regard to decision making, no parliament in Latin America has been endowed with any kind of legislative power. Output legitimacy, insofar as this exists, is certainly not a product of any of these regional parliamentary institutions. As for control legitimacy, Parlacen stands out again as the only assembly to possess any - albeit very weak - powers regarding the monitoring of other regional bodies. In stark contrast to all the Latin American cases, the EP enjoys ever stronger capacities concerning all of the relevant four dimensions. There are many factors that account for such a difference; we outline five of them below and suggest an agenda to promote further research.

The first factor that distinguishes the evolution of regional parliaments across the Atlantic is time: the process of European integration started between two and four decades before the Latin American processes, so differences regarding institutional development may be due to maturity gaps. The second factor is sequence: the current structure of the EU was set up according to the "Monnet-method", meaning that function should precede form and that incrementalism is preferred to early institutionalisation. Some Latin American groupings, by contrast, have unsuccessfully attempted to skip phases, admiring of the outcome of the European process but overlooking how this had been achieved. Third, there is a wide disparity regarding the level of integration: while the EU is already a common market and is consolidating into an economic union, none of its Latin American counterparts have yet reached the level of a customs union; logically, the institutional structure needed for one type of organisation does not necessarily satisfy the requirements of others. Fourth, the degree of success in the creation of regional institutions cannot be dissociated from the effectiveness with which institutions work at home; in other words, weak or unstable domestic institutions are not a good foundation upon which to build international institutions. Fifth, most European countries feature parliamentary or semi-parliamentary regimes, whereas all Latin American countries have presidential ones. An important consequence of such a difference is that a "parliament" does not mean the same thing on both sides of the Atlantic: if, in Europe, it is conceived of as the supreme institution where government is ultimately made and undone, in Latin America the election, authority and survival of the government are independent of parliamentary will. It would be unreasonable to assume that chief executives of presidential regimes would not replicate, on the regional level, a feature that fits them well on the domestic level (Malamud, 2005a).

The main implication derived from the last argument is that, also within processes of regional integration, presidential or parliamentary domestic 


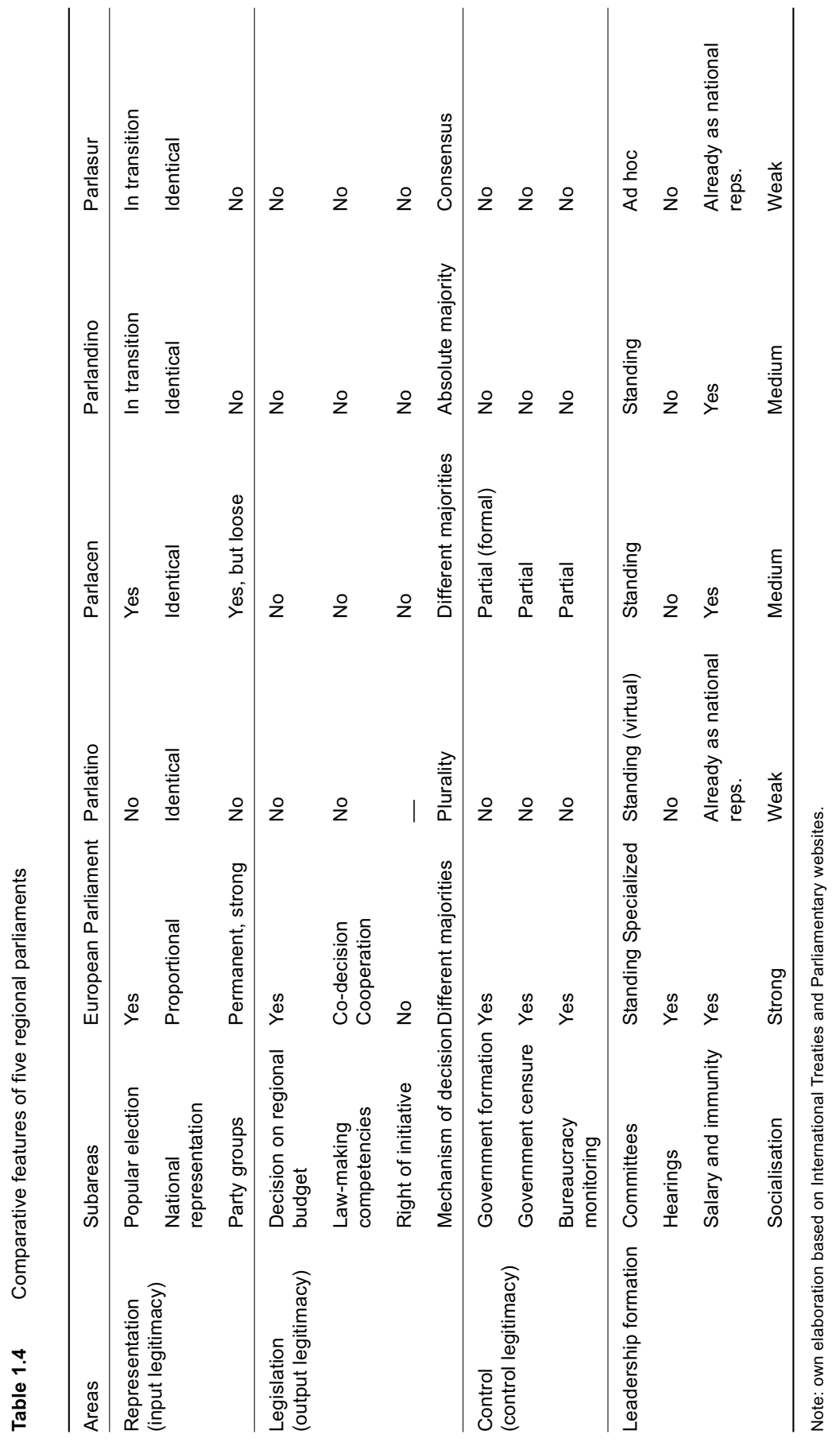


regimes do make a difference - especially regarding the settlement of regional parliaments. As a related consequence, political parties also matter in different ways and for different reasons from one regional setting to another. Political reformers would do well to take these conclusions into consideration, as it has even been argued that a parliamentary system may not be the most appropriate solution for governing a multi-state democracy (Fabbrini, 2004; Hix, 2002; McKay, 2001). The implications of this statement regard the future of regional parliaments not only in Latin America but also elsewhere - including Europe. Bi-regional forums such as the Euro-Latin American Parliamentary Assembly (Eurolat) ${ }^{8}$ could play a role in helping regional parliaments to prevent failure by avoiding the creation of unrealistic expectations.

Apart from the classical functions considered in this chapter, regional parliaments may help to accomplish complementary goals such as nurturing a common regional identity among political elites, strengthening the symbolic presence of the regional organisation in the minds of the public and third countries, and facilitating intra-regional communication. They may also promote unexpected spillovers. However, these functions are neither exclusive to nor characteristic of parliamentary institutions. If regional parliaments are to be enhanced, the distinction between their constitutive and complementary functions should not be neglected. Entertaining unrealistic proposals, whether based on ingenuous emulation or on insufficient understanding, will most likely doom the enterprise to failure or - at best - irrelevance.

\section{References}

Bardi, Luciano (1996), “Report: transnational trends in European parties and the 1994 elections of the European Parliament", Party Politics, 2/1, pp 99-114.

Bonilla, Adrián (2001), “Entre el Deseo y la Ficción. Interdependencia y Integración en la Región Andina", XXIII LASA World Congress, Washington D.C., September 6-8.

Caetano, Gerardo, and Romeo Pérez Antón (2003), “Hacia un Parlamento del Mercosur", in G. Caetano and R. Perina (eds.), La Encrucijada Política del Mercosur. Parlamentos y Nueva Institucionalidad, Montevideo, CLAEH-OEA.

Caetano, Gerardo, and Rubén Perina (eds.) (2000), Mercosur y Parlamentos. El Rol de los Congresos en la Democracia y la Integración, Montevideo, CLAEH-OEA.

Caetano, Gerardo, and Rubén Perina (eds.) (2003), La Encrucijada Política del Mercosur. Parlamentos y Nueva Institucionalidad, Montevideo, CLAEH-OEA.

8 Eurolat brings together 120 parliamentarians from the European Parliament, the Andean Parliament, the Central American Parliament and the Latin American Parliament, as well as national representatives from the Mexican and Chilean legislatures, and members of the joint parliamentary committee of Mercosur. Eurolat succeeded a previous forum, the Euro-Latin American Inter-parliamentary Conference, in November 2006. 
Caputo, Dante (1999), Personal Interview, Former Argentine Foreign Minister, Buenos Aires, September.

CEFIR, Centro de Formación para la Integración Regional (1998), “La Comisión Parlamentaria Conjunta: una visión de su funcionamiento: documento de síntesis", presented at Perspectivas Institucionales del Mercosur. Organización y Funcionamiento de la Comisión Parlamentaria Conjunta, workshop organised by CEFIR and the Joint Parliamentary Commission of Mercosur, Buenos Aires, June 2-4.

Corbett, Richard (1998), The European Parliament's Role in Closer EU Integration, Basinstoke, Palgrave.

Costa, Olivier (2001), Le Parlement Européen, Assemblée Délibérante, Brussels, Institut d'Études Européennes.

Fabbrini, Sergio (2004), "Transatlantic constitutionalism: comparing the United States and the European Union", European Journal of Political Research, 43 (4), pp. 547-569.

Hix, Simon (2002), Why the EU Should Have a Single President, and How She Should be Elected, paper for the UK Cabinet Office, London, LSE.

Hix, Simon, Tapio Raunio, and Roger Scully (2003), "Fifty years on: research on the European Parliament", Journal of Common Market Studies, 41/2, pp. 191-202.

Malamud, Andrés (2003), "Presidentialism and Mercosur: a hidden cause for a successful experience", in Finn Laursen (ed.): Comparative Regional Integration. Theoretical Perspectives, London, Ashgate, pp. 53-73.

Malamud, Andrés (2004), "Regional integration in Latin America: comparative theories and institutions", Sociologia, Problemas e Práticas, 44, pp. 135-154.

Malamud, Andrés (2005a), "Presidential diplomacy and the institutional underpinnings of Mercosur: an empirical examination", Latin American Research Review, 40 (1), pp. 138-164.

Malamud, Andrés (2005b), “Mercosur turns 15: between rising talk and declining achievement", Cambridge Review of International Affairs, 18 (3), pp. 421-36.

McKay, David (2001), Designing Europe. Comparative Lessons from the Federal Experience. Oxford, Oxford University Press.

Mény, Yves (1998), The French Political System, Paris, La Documentation Française.

Nuttens, Jean-Dominique, and François Sicard (2000), Assemblées Parlementaires et Organisations Européennes, Paris, La Documentation Française.

Orlandi, Hipólito (1998), "Parlamentos y congresos”, in Hipólito Orlandi (ed.), Las Instituciones Políticas de Gobierno, Buenos Aires, EUDEBA.

Peña, Félix (1998), “El Desarrollo Institucional del Mercosur”, in AA.VV., Comunidad Andina y Mercosur. Desafíos Pendientes de la Integración en América Latina, Bogotá, Ministerio de Relaciones Exteriores de Colombia y Corporación Andina de Fomento.

Pereira, Celso (2000), "Personal interview", Brazilian diplomat, Brasilia, December. Quermone, Jean-Louis (2002), Le Systéme Politique de l'Union Européenne, Paris, Montchrestien (Clefs/Politique), $5^{\text {th }}$ edition. 
Rittberger, Berthold (2003), "The creation and empowerment of the European Parliament", Journal of Common Market Studies, 41 (2), pp. 203-225.

Scarrow, Susan (1997), "Political career paths and the European Parliament", Legislative Studies Quarterly, 22 (2), pp. 253-62.

SM, Secretaría del Mercosur (2004), Un Foco para el Proceso de Integración Regional. Primer Informe Semestral de la Secretaría del Mercosur, Montevideo, Secretaría del Mercosur.

Vazquez, Mariana (2001), La Comisión Parlamentaria Conjunta del Mercosur. Reflexiones sobre su Trayectoria Político-Institucional, paper delivered at the 2001 Meeting of the Latin American Studies Association, Washington DC, September 6-8.

Urwin, Derek W. (1997), A Political History of Western Europe Since 1945, London and New York, Longman.

Vieira Posada, Edgar (2000), “Perspectivas de la integración: el rol de los parlamentos regionales", in Adriana Delgado, Ronny Rodríguez and Marcelo Alvarez (eds.), El Poder Legislativo en la Democracia y la Integración Andina, Bogotá, Colombia, UPD/OEA and Universidad Javeriana.

Weber, Max (1994), "Parliament and government in Germany under a new political order", in Max Weber, Political Writings, Cambridge, Cambridge University Press, pp. 130-271.

\section{Parliaments' websites}

International Parliamentary Union: http://www.ipu.org/english/home.htm

European Parliament: http://www.europarl.eu.int/

Latin American Parliament: http://www.parlatino.org/

Central American Parliament: http://www.parlacen.org.gt/

Andean Parliament: http://www.parlamentoandino.org/

Mercosur Parliament: http://www.parlamentodelmercosur.org/ 


\title{
Ideological identities in Europe \\ Comparative perspective of Portugal, Spain and Greece
}

\author{
André Freire
}

\section{The importance of the division between left and right in mass politics}

Since the French Revolution, the division between left and right has been of fundamental importance in mass politics, most of all in Continental Europe (Laponce, 1981). ${ }^{1}$ This political split has since then served as a form of categorising ideologies; as an instrument of classification of the political positions of the different parties (and/or candidates/the elected representatives); as a code of communication between political forces, mass media and voters; and, finally, as an instrument to orientate the voters in the interpretation of the political phenomena and in the making of decisions. The division between left and right functions, on the individual level, as an instrument to reduce the complexity of the political universe and, on the systemic level, as a code of communication (Fuchs and Klingemann, 1990: 205; Luhmann, 1982).

In spite of all the theories about the "end of ideology" (for example, Bell, 1960; Lipset, 1981), about the "end of history" (Fukuyama, 1989), and about a certain overcoming of the division between left and right (Giddens, 1996), the truth is that these same theories have been clothed with an ideological character and, soon after being formulated/defended, were followed by the appearance of new ideological forms or by a renewed prominence of "old" ideologies (Heywood, 2003: 319-323; Eatwell, 2003: 279-290).

Furthermore, various studies have documented the growing importance of the position of the electors on the left-right scale as a defining factor of their voting choices. Gunther and Montero (2001: 124-126) have shown that, between the decades of 1980 and 1990, a decline in the impact of the social

1 The author would like to thank António Firmino da Costa, as well as the organizers of this volume, for the generous invitation to participate in this book. 
cleavages in the vote was identified in Portugal, Spain, Italy and Greece, as well as in the various Western European countries and North America, comparatively speaking. However, with respect to the impact of the citizens' left-right positioning regarding their electoral choices, the conclusion was precisely the opposite, whether for the four countries in Southern Europe, or for various others (Gunther and Montero, 2001: 127; see also Freire 2004a).

Other studies have shown a similar tendency for Belgium, Denmark, Holland, New Zealand and Sweden (Franklin et al., 1992). Also in absolute terms, for each election, the ideology (measured in the referred form) reveals itself, generally, as the most important or as one of the most important predictors of partisan choice (Franklin et al., 1992; Gunther and Montero, 2001; Freire, 2003 and 2004a).

Taking into account the enormous importance of the position on the left-right scale for the political orientation of the European voters, as well as the various omissions in the existent literature regarding the subject), in this work we have two main objectives. First, to analyse the extension and evolution of ideological identities (positioning on the left-right scale) for European voters, between 1976 and 2002, an approach that will permit us, among other things, to test the thesis regarding the "end of ideology". Second, to verify if the increase of voters being located at central positions on the ideological spectrum can be interpreted as an indicator of growing irrelevance of the left-right division. In this way, we intend to assess whether or not there is a growth of ideological centrism, as the "end of ideology" thesis presuppose. Third, we intend to assess in what measure the left-right orientation of the voters is more or less subject to situational influences, or rather, to short-term factors. Fourth, with regard to all of the analysis mentioned above, we intend to verify whether or not there are systematic differences between the "new" democracies of Southern Europe (Portugal, Spain and Greece) and the older polyarchies of the Western part of the old continent. In other words, bearing in mind the fact that the formation of ideological identities is strongly dependent upon the socialisation of individuals in an environment of effective political and ideological competition, will there be systematic differences between the new and the old democracies? We will return to this point later.

\section{Ideological identities}

In the vein of the seminal study by Inglehart and Klingemann (1976), as well as of its various protractors (Freire, 2004b: 9-62), it has been considered that the positioning of voters on the left-right scale ${ }^{2}$ basically has three components: a

2 Regarding the different formats of the left-right scale used in the present article, see table A.1 in the Annex. 
social dimension, which has to do with the relations between the ideological orientations of the individuals and their anchorage in the social fabric; another based upon values, which has to do with the associations between the orientations of the individuals with regards to the different value systems (socioeconomic, religious and "new politics") and their positioning on the left-right scale; thirdly, the partisan component of ideology refers to that part of ideological positioning which, not being explainable by the individual's value choices, is dependent upon party identification. ${ }^{3}$ In other words, in this case the individuals position themselves to the left or the right more as a result of identifying themselves with parties of the left or the right, respectively, than of sharing determined preferences regarding public policies and/or subjacent value systems.

In the new democracies, it's not very plausible that ideological identities reflect partisan loyalties above all, given that these are not even completely settled, at least in the first years of the new regimes. Therefore, one of the possible alternatives is to consider the partisan component of ideology as a mechanism that functions similarly to party identification, but which consists more of a type of spatial identity that after is converted into a guide for partisan choices, namely in terms of vote (Sani and Montero, 1986). It is therefore in this last sense that we will adopt the concept of the partisan component ideology: a spatial identity (with determined area of the ideological spectrum) which functions similarly to party identification and with which a structured collection of attitudes about public policies/value systems is not necessarily associated, being able therefore to function independently of these orientations.

\section{Reasons for an analysis of the evolution of ideological identities in Europe}

The deeper analysis of the three Southern European countries has a theoretical relevance which is appropriate for the analysis of the phenomena of the formation, nature and evolution of ideological identities, considering that new democracies are involved (Converse, 1969; Barnes, McDonough and Pina, 1985; Niemi et al., 1985; Gunter and Montero, 2001: 88 and 92-94; Barnes, 2002). First, because the process of the formation of ideological (and partisan) identities continues to be developed throughout the process of (primary and secondary) socialisation of the individual (Campbell et al., 1960; Converse, 1964 and 1969; Niemi et al., 1985; Barnes, McDonough and Pina, 1985).

3 Regarding the concept of party identification, see Campbell et al., 1960; see also Freire, 2001, chapter 2, for a review of controversies surrounding this concept. 
Second, considering that the formation of these identities is strongly dependent upon the existence of an environment of effective partisan and ideological differentiation, associated with the existence of free political competition. In the authoritarian regimes existent until the beginning of the 1970s in Southern Europe, the political parties were a proscribed reality and ideological differences were repressed. In the second half of the twentieth century, with the exception of Greece, only following the democratic transitions of the 1970s were partisan and ideological pluralism implanted there.

In spite of partisan and ideological pluralism being repressed by the dictatorial regimes of Southern Europe, this does not mean that such pluralism did not exist at all. Regardless, it was very limited. On the other hand, during the dictatorial interregnum, the experiences and contacts with the notions and forces associated with such pluralism, whether it was by way of oppositional currents, or by way of contacts with foreign democratic nations, always reached limited segments of the populations of Portugal, Spain and Greece (Freire, 2004b). Therefore, the conditions for the formation of ideological (and partisan) identities were sufficiently reduced, above all when we compare these new regimes with the older democracies of Western Europe.

Even in competitive political environments, for the individuals to identify themselves with determined parties and with determined ideological areas, it is necessary that these political organisations and notions, as well as the image and content that define and/or are associated with them, consolidate their presence in the political arena (Converse, 1969; Barnes, McDonough and Pina, 1985; Niemi et al., 1985; Gunther and Montero, 2001: 88 and 92-94; Barnes, 2002).

As a result, it is above all hoped that the levels of ideological identification in the new democracies present, initially, lower values than in the older polyarchies, especially in Portugal and Spain. Taking into account that the dictatorial interregnum was more limited in Greece (1967-1974), and that various elements of continuity in political objects existed (ideological currents, parties and leaders) before and after the regime of the colonels (Freire, 2004b), it is expected that in this country the differences with regard to older democracies will be less salient than in the cases of Spain and Portugal. Furthermore, it is also expected that the new democracies will present an upward tendency in the levels of ideological identities, at least during the first decades of the democratic regime, above all Portugal and Spain. Rather, at least in the initial periods of democratic life, it is not expected that the new democracies be affected by the decline of ideological identities. Thirdly, it is expected that, in the new democracies, the left-right orientations of the voters will be less stable. In other words, it is expected that, in the new regimes, ideological identities will be more permeable to situational factors than in the older democracies.

However, the analysis of the evolution of ideological orientation is not only relevant in terms of the new democracies of Southern Europe. In the first 
place, because the comparative and updated study of the evolution of ideological identities, in terms of left and right, is, as far as we know, clearly to be done on the level of sociology and of political science. ${ }^{4}$ Secondly, because the comparative analysis of the evolution of these left-right orientations in Western Europe will allow the theories regarding the "end of ideology" to be submitted to empirical proof. Thirdly, because upon verification of a systematic and linear increase of the positioning of the voters at the central points on the left-right scale, we will be able to consider that we are facing a growing irrelevance of the left-right dimension (Knutsen, 1988: 303-304). Therefore, testing whether or not there effectively exists a linear growth in ideological centrism in Western Europe we can, once again, scrutinise whether or not evidence exists which upholds the theories regarding the "end of ideology".

\section{Decline of ideological identities in Europe?}

The "theory of partisan dealignment" (Dalton, 2000) predicts a (structural) decline of the identification of individuals with political parties. Many of the factors that explain this decline will also tend to influence ideological identities in the sense of their diminishment, in so far as it is known that these also have a strong partisan component. For example, the increase in the level of education and of political information on the part of the voters will also be able to make ideological identities less functional while instruments of cost reduction for the making of political and electoral decisions. Additionally, the personalisation of politics, the decline in the ideological differences between parties (with the predominance of parties of the masses giving way to the predominance of the catch-all parties), and the growth of political marketing, etc., are all factors that point to a decline of the ideological identities of citizens.

Ideologies are typical phenomena of industrial societies, clearly branching out from the illuminist tradition (even in the situations where they are mere reactions to it, as in the case of the reactionary right). Nevertheless, since the 1950s, various authors have observed in the industrial societies (and/or defended, in the case of the more philosophical/normative perspectives) the decline or even the end of ideologies, at least as structured and closed systems of thought, or rather as total ideologies (Communism, Nazism, etc.) (Bell, 1960, especially pp. 409-447; Lipset, 1981).

More recently, whether in a more normative perspective, as in the case of the theories of the third way (Giddens, 1994, 1998 and 2000), or in an empirical approach, as in the case of the analysis of the ideological positioning of

The only comparative study that we note (Knutsen, 1998) is clearly outdated - it only covers the period between the 1970s and the beginning of the 1990s - and furthermore it does not include Portugal, Spain and Greece. 
the political parties (Mair, 1998: 131-136), some social scientists have defended and/or observed the existence of a decline in the importance of the differentiation between the left and the right.

However, these positions are far from being consensual. First, the theories about the "end of ideologies" are in themselves ideological (Eatwell, 2003; Heywood, 2003). Second, after being formulated, they have been succeeded by renovations of the ideological spaces, such as the "new left" and the "new right", from the 1960s to the present, and the revival of nationalism and of fundamentalism, in recent periods (Eatwell, 2003; Heywood, 2003).

In a more normative perspective, Norberto Bobbio defends that social inequalities persist in today's world, above all between the rich countries (of the first world) and the remaining countries (of the third world), and, therefore, he considers that there is certainly space for a renewed importance to be placed upon the differentiation between left and right, even in new patterns (Bobbio, 1994: 95-101). On a more empirical level, a recent study based upon content analyses of the electoral manifestos of the political parties in the western democracies, 1945-1998, is far from corroborating the theory of the "end of ideology", fundamentally for two reasons. First, there are no general tendencies with regard to the evolution of the proposals of the political parties. Second, the variability is not only between countries but also in the heart of each country, with oscillations in the levels of ideological polarisation between elections (Budge and Klingemann, 2001: 19-50).

In an analysis about party types, from the middle of the $19^{\text {th }}$ century until the end of the $20^{\text {th }}$, Gunther and Diamond (2003, especially pp. 187 and 191-193) show that, on the level of party profile, the theory of the decline or end of ideologies has a limited empirical base, exemplifying this argument with the increase of the ideological character of the republican party during the 1980s, with Ronald Reagan, and of the conservative party during the 1970s and 1980s, with Margaret Thatcher.

Finally, the great (and, in many countries, the growing) importance of the division between left and right in explaining the electoral decision of the voters (Franklin et al., 1992; Gunther and Montero, 2001; Freire, 2003 and 2004a), also points in the direction opposite to that of the theories of the end of ideology. Therefore, if it's true that there is a relative consensus as to the decline of party identification in the West (Schmitt and Holmberg, 1995; Dalton, 2000; Freire, 2004b, Chap. 4), especially with respect to the older democracies, as we had the opportunity to show, such is not verified with regards to ideological identities. Actually, with regards to identification with political parties, the controversies as to their decline are centred fundamentally around their degree of generality (in terms of older Western democracies) and around the causes of such phenomena, the two questions being interconnected. On the contrary, the positions about the evolution of ideological 


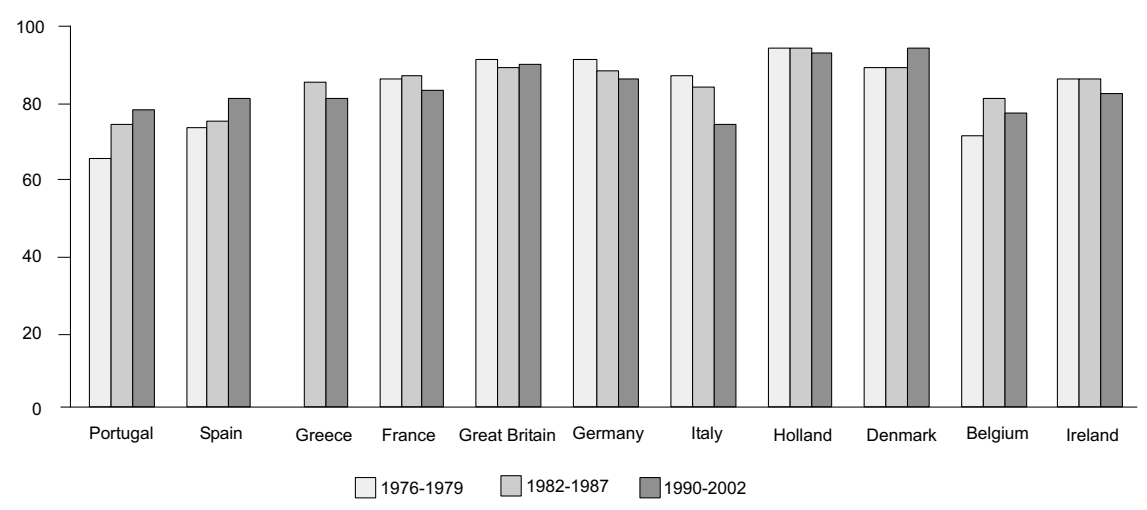

Figure 2.1 Lelf-right self-placement in Europe, 1976-2002 (average percentage by decade)

Note: (1) the detailed distributions of the variable for countries and years, which underlie the averages presented in the figure, can be consulted in Freire, 2006, Appendix III, or furnished by the author upon request; (2) weighted data (sociodemographic weights).

Sources: data elaborated by the author based upon European Community Studies, Cumulative File, 1970-92 (1976-91); Eurobarometer 44.1 (1994); European Election Study 1999; Eurobarometer 57.1 (2002); Spain and Portugal, only 2000 and 2002, respectively: Comparative Study of Electoral Systems, Module 2; only for Portugal in 1978-1984: Bacalhau, n. d.: 47, and Bacalhau, 1994: 58; Spain, 1982: Eurobarometer 18, in Barroso and Condomines, 1985: 43; Spain in 1978 and 1984, Barnes, McDonough and Pina, 1985: 701.

identities are much more controversial. Let us pass to the empirical data to assess the degree of support of these different positions.

In figure 2.1 we present the average percentages, per decade, of individuals in different European countries who were capable of being positioned on the left-right scale (ten, 1-10, or eleven, $0-10$, point scales, which span from left, 1 or 0 , to right, 10). In each country, the percentages lacking to achieve $100 \%$ correspond to those individuals who did not respond to the question or who refused to respond, that is, those who did not recognise the division between left and right, or who did not consider it relevant. We should bear in mind that in various countries the series does not cover all the included years, especially with regard to the new democracies of Southern Europe.

According to the data presented in figure 2.1, the countries which exhibit the highest levels of ideological orientations are Holland, Denmark, Great Britain, Germany and Ireland. On the contrary, the countries with lower levels of ideological identification are, in ascending order, Portugal, Spain, Belgium and Greece. The intermediate positions are occupied by France and Italy, whose stature is owed to the variable character of the levels of ideological identification in each of the periods being analysed. In the first case, the values for the 1980s are on level with those of the first group, even though slightly below. However, in the decades of the 1970s and, above all, 
Table 2.1 Left-right self-placement in Europe, 1976-2002 (OLS regressions)

\begin{tabular}{lcr|rr}
\hline \multirow{2}{*}{ Country } & \multirow{2}{*}{ Period } & \multicolumn{2}{|c}{ Dependent variable: left-right self-placement } \\
\cline { 4 - 5 } & & Constant & Regression coefficient \\
\hline Portugal (I) & $1978-02$ & 10 & $-1350.283 * * *$ & $0.717 * * *$ \\
Spain & $1978-02$ & 10 & $-1601.767 * * *$ & $0.844^{* * *}$ \\
Greece (I) & $1982-02$ & 9 & 990.792 & -0.456 \\
Greece (II) & $1980-02$ & 12 & 481.341 & -0.201 \\
France & $1976-02$ & 13 & $586.725 * *$ & -0.104 \\
Great-Britain & $1976-02$ & 13 & 296.171 & -0.246 \\
Germany & $1976-02$ & 13 & $575.673 *$ & $-0.669 * * *$ \\
Italy & $1976-02$ & 13 & $1409.657 * * *$ & 0.002 \\
Netherlands & $1976-02$ & 13 & 44.611 & $0.303 * * *$ \\
Denmark & $1976-02$ & 13 & $-510.941 * * *$ & 0.180 \\
Belgium & $1976-02$ & 13 & -280.968 & -0.188 \\
Ireland & $1976-02$ & 13 & $458.513 *$ & $*$ \\
\hline
\end{tabular}

Notes: (1) Dependent variable: left-right self-placement in each country (percentage of individuals who are able/willing to place themselves on the scale); (2) Independent variable: years in ascending chronological order; (3) ${ }^{\star \star *} \mathrm{p} 0.01$; ** $\mathrm{p} 0.05 ;{ }^{*} \mathrm{p} 0.1$.

Sources: 1) See figure 2. 1; 2) In the case of Greece (I and II), an additional series was also used concerning the years of 1980, 1981 and 1983 (Greece II) (Eurobarometer data in Barroso and Condomines, 1985, p. 48).

the 1990s, they are lower. In the case of Italy, the values for ideological identities are on level with the group with greater ideological extension in the 1970s and in the 1980s, but from the latter decade on there is an abrupt decline that places the transalpine nation on the intermediate scale of countries.

In general, we can say that our expectations are confirmed, or in other words, the lower levels of ideological identification are concentrated in the new democracies of Southern Europe. However, the Belgian case shows that not everything is based upon to the longevity of the democratic regime. In this country, where ethnic and linguistic questions have reduced the salience of the left-right divide (Freire, 2004b, chapter 3), the level of ideological identification is also relatively low. On the other hand, Italy presents an erosion of ideological identities in such a strong way, that the complete restructuring of the partisan system during the decade of the 1990s will not be irrelevant, presenting in the final decade being analysed (1990-2002), together with Portugal and Belgium, the lowest levels of ideological identification. The case of Italy clearly shows the partisan component of ideology: with the collapse and transformation of the party system in the first half of the 1990s, ideological identities fell abruptly.

The analysis of trends through graphs is potentially imprecise and, therefore, we resort to a method identical to that used by Schmitt and Holmberg (1995: 101), as well as by Dalton (2000: 25-26), to precisely evaluate the existence (or non-existence) of eventual trends in these areas. In other words, taking as dependent variable the "percentage of individuals who position themselves on the left-right scale", in each country and year, 
and as independent variable the years for which data is available to us, ordered in ascending chronological order, OLS regression was used in seeking to identify eventual trends.

With regards to the evolution of ideological identities, there are five coefficients that show an increase in the extension of the same among the populations: in Portugal, Spain, Holland, Denmark and Belgium (Freire, 2004b: 207, table 4.3). Furthermore, only in the cases of Holland and Belgium is the increase not statistically significant. All of the other six coefficients show a decline in ideological identities among the populations, although in Greece, in Great Britain and in Ireland such tendencies are not statistically significant.

In the line of Dalton (2000: 25), and of Dalton and Wattenberg (2000: 62-63), we believe, nevertheless, that taking into account the reduced number of cases in the temporal series used, the questions of statistical significance have to be made relative. Dalton and Wattenberg (2000: 62-63) establish as a rule that an annual variation of 0.3 in a temporal series will be significant, even if the tests of significance do not reveal this due to the reduced number of cases, because variations of $6 \%$ between two samples of 1,500 cases are always statistically relevant.

As a result, if in the case of Greece the lack of statistical significance of the coefficient (-0.456) (indicating the erosion of ideological identities) owes itself more to the reduced number of cases, in Great Britain (-0.104), in Germany (-0.246), in Holland (0.002), in Belgium (0.180) and in Ireland (-0.188) the variations are so low (as shown by the absolute values of the coefficients) that it will be more correct to speak in terms of the stability of ideological identities. Even in the case of Greece, it is questionable whether or not we will be effectively facing an erosion of ideological identities between the decades of 1980 and 1990; more concrete conclusions regarding this subject lack a more extensive temporal series. In this sense, we extended the Greek series slightly, adding to the initial series (Greece I) the years 1980, 1981 and 1983 (Greece II), taken from Eurobarometers realised in these years (the source is Barroso and Condomines, 1985: 48). With the new series, we continue to have a declining evolution, although a much weaker one (-0.201). Even though, also in this case, the decline is not statistically significant, the graphic representation points to a scenario of stabilisation: for example, the average for the decade of the 1980s is now $83 \%$ (as opposed to the previous averages of $85 \%$ ) and that of the decade of the 1990 s is $81 \%$. On the other hand, the absolute value of the coefficient is already slightly below the limit of 0.3 defined. Therefore, it seems advisable to conclude in favour of a stabilisation of ideological identities in Greece, instead of in favour of their decline. Furthermore, the absence of available data for the 1970s, in Greece, as opposed to what happened in Spain and Portugal, prevents us from having a comprehensive view of the evolution of ideological identities in 
that country since the democratic transition, strictly comparable to the two countries on the Iberian Peninsula. ${ }^{5}$

Concluding: from a group of eleven countries, five show an increase in the percentage of citizens who position themselves on the left-right axis. However, only in three of these cases are the results statistically significant and two cover the new democracies of Southern Europe. Of the remaining six countries, only in two is there a clear decline in the identification with the division between left and right, the situation being stable in the remaining countries. Therefore, this data does not corroborate the hypothesis of the "end of ideologies", or even of its general decline. In fact, even withholding the new democracies (leaving a group of eight countries) we are left with the following panorama, which also does not sustain the mentioned hypothesis: in two countries there is a decline, in five the scenario is of stability and in one it has an increasing nature. Furthermore, the diversity of tendencies among countries shows such evolutions as not being explainable by socio-structural factors. In this regard, the relevant evolutions are common to the different countries and, therefore, the diversity of tendencies with regards to the evolution of ideological identities will have to be explained by specific (and generally political) factors for each country.

\section{Linear and systematic growth of ideological centrism in Europe?}

So as to analyse the evolution of the distribution of ideological alignment in Western Europe, between 1976 and 2002, the positioning on the left-right scale of 10 points has been converted to a span of only 3 points, in the following manner: 1 to $4-1$ (left), 5 to $6-2$ (centre), 7 to $10-3$ (right). ${ }^{6}$ This is the solution which is generally used in the Eurobarometers and which is also best coordinated with the number of cases and the necessary intelligibility in the representation of data.

One way to verify the existence of an eventual systematic and linear movement towards the ideological centre is to compare the percentage of people located at the centre of the ideological spectrum during each decade. In table 2.2, we present the average percentages of people located in each of the three ideological categories (left, centre and right), in each country and during each decade. For each country, we also present a variation, measured through the difference in average percentages, between the decades of the

5 There are some differences between the results presented in table 2.1 and identical results presented in Freire, 2004b and 2005. These differences are due to the weighting procedures used in the present article. However, those differences do not impact the basic general conclusions. In fact, quite the opposite is true: the conclusions are strengthened. (1-10), we used the formula presented by Knutsen (1998: 65 and 93, note 8). 
Table 2.2 Evolution of left-right alignments in Europe, per decade, 1976-2002

\begin{tabular}{|c|c|c|c|c|c|c|}
\hline Country & Ideological position & $\begin{array}{c}1976-1978 \\
\text { (A) }\end{array}$ & $\begin{array}{c}1982-1987 \\
\text { (B) }\end{array}$ & $B-A$ & $\begin{array}{c}1991-2002 \\
\text { (C) }\end{array}$ & $C-A$ \\
\hline Portugal & $\begin{array}{l}\text { Left } \\
\text { Centre } \\
\text { Right }\end{array}$ & $\begin{array}{l}28.0 \\
51.1 \\
21.0\end{array}$ & $\begin{array}{l}29.2 \\
39.7 \\
31.1\end{array}$ & $\begin{array}{r}1.2 \\
-11.4 \\
10.1\end{array}$ & $\begin{array}{l}27.9 \\
46.8 \\
25.4\end{array}$ & $\begin{array}{r}-0.1 \\
-4.4 \\
4.4\end{array}$ \\
\hline Spain & $\begin{array}{l}\text { Left } \\
\text { Centre } \\
\text { Right }\end{array}$ & $\begin{array}{l}42.5 \\
42.6 \\
15.0\end{array}$ & $\begin{array}{l}47.6 \\
33.3 \\
19.2\end{array}$ & $\begin{array}{r}5.1 \\
-9.3 \\
4.2\end{array}$ & $\begin{array}{l}45.5 \\
36.1 \\
18.4\end{array}$ & $\begin{array}{r}3.0 \\
-6.5 \\
3.4\end{array}$ \\
\hline Greece & $\begin{array}{l}\text { Left } \\
\text { Centre } \\
\text { Right }\end{array}$ & $\begin{array}{l}- \\
- \\
-\end{array}$ & $\begin{array}{l}37.3 \\
37.5 \\
25.3\end{array}$ & $\begin{array}{l}- \\
- \\
-\end{array}$ & $\begin{array}{l}24.2 \\
41.5 \\
34.3\end{array}$ & $\begin{array}{r}-13.0 \\
4.1 \\
9.0\end{array}$ \\
\hline France & $\begin{array}{l}\text { Left } \\
\text { Centre } \\
\text { Right }\end{array}$ & $\begin{array}{l}41.2 \\
35.6 \\
23.3\end{array}$ & $\begin{array}{l}36.3 \\
39.1 \\
24.7\end{array}$ & $\begin{array}{r}-4.9 \\
3.5 \\
1.4\end{array}$ & $\begin{array}{l}39.4 \\
37.3 \\
23.4\end{array}$ & $\begin{array}{r}-1.7 \\
1.7 \\
0.1\end{array}$ \\
\hline $\begin{array}{l}\text { Great } \\
\text { Britain }\end{array}$ & $\begin{array}{l}\text { Left } \\
\text { Centre } \\
\text { Right }\end{array}$ & $\begin{array}{l}20.2 \\
43.8 \\
36.1\end{array}$ & $\begin{array}{l}21.5 \\
46.1 \\
32.5\end{array}$ & $\begin{array}{r}1.3 \\
2.3 \\
-3.6\end{array}$ & $\begin{array}{l}27.9 \\
48.3 \\
23.9\end{array}$ & $\begin{array}{r}7.7 \\
4.6 \\
-12.2\end{array}$ \\
\hline Germany & $\begin{array}{l}\text { Left } \\
\text { Centre } \\
\text { Right }\end{array}$ & $\begin{array}{l}23.3 \\
40.2 \\
36.6\end{array}$ & $\begin{array}{l}31.2 \\
39.3 \\
29.6\end{array}$ & $\begin{array}{r}7.9 \\
-0.9 \\
-7.1\end{array}$ & $\begin{array}{l}31.8 \\
45.3 \\
23.0\end{array}$ & $\begin{array}{r}8.5 \\
5.1 \\
-13.7\end{array}$ \\
\hline Italy & $\begin{array}{l}\text { Left } \\
\text { Centre } \\
\text { Right }\end{array}$ & $\begin{array}{l}48.3 \\
38.5 \\
13.2\end{array}$ & $\begin{array}{l}43.5 \\
40.4 \\
16.1\end{array}$ & $\begin{array}{r}-4.8 \\
1.9 \\
2.9\end{array}$ & $\begin{array}{l}36.8 \\
35.3 \\
28.0\end{array}$ & $\begin{array}{r}-11.6 \\
-3.2 \\
14.8\end{array}$ \\
\hline Netherlanc & $\begin{array}{l}\text { sLeft } \\
\text { Centre } \\
\text { Right }\end{array}$ & $\begin{array}{l}31.7 \\
31.8 \\
36.5\end{array}$ & $\begin{array}{l}34.9 \\
34.4 \\
30.7\end{array}$ & $\begin{array}{r}3.2 \\
2.6 \\
-5.8\end{array}$ & $\begin{array}{l}32.3 \\
36.6 \\
31.1\end{array}$ & $\begin{array}{r}0.5 \\
4.8 \\
-5.4\end{array}$ \\
\hline Denmark & $\begin{array}{l}\text { Left } \\
\text { Centre } \\
\text { Right }\end{array}$ & $\begin{array}{l}24.5 \\
47.3 \\
28.3\end{array}$ & $\begin{array}{l}25.5 \\
41.2 \\
33.4\end{array}$ & $\begin{array}{r}0.9 \\
-6.1 \\
5.1\end{array}$ & $\begin{array}{l}27.3 \\
34.9 \\
37.8\end{array}$ & $\begin{array}{r}2.8 \\
-12.3 \\
9.6\end{array}$ \\
\hline Belgium & $\begin{array}{l}\text { Left } \\
\text { Centre } \\
\text { Right }\end{array}$ & $\begin{array}{l}20.7 \\
37.1 \\
42.2\end{array}$ & $\begin{array}{l}24.8 \\
41.4 \\
33.9\end{array}$ & $\begin{array}{r}4.1 \\
4.3 \\
-8.4\end{array}$ & $\begin{array}{l}28.7 \\
44.3 \\
26.8\end{array}$ & $\begin{array}{r}8.0 \\
7.3 \\
-15.4\end{array}$ \\
\hline Ireland & $\begin{array}{l}\text { Left } \\
\text { Centre } \\
\text { Right }\end{array}$ & $\begin{array}{l}16.1 \\
47.6 \\
36.3\end{array}$ & $\begin{array}{l}14.5 \\
45.6 \\
39.9\end{array}$ & $\begin{array}{r}-1.6 \\
-2.0 \\
3.6\end{array}$ & $\begin{array}{l}20.5 \\
46.2 \\
33.4\end{array}$ & $\begin{array}{r}4.4 \\
-1.5 \\
-2.9\end{array}$ \\
\hline
\end{tabular}

Notes: 1) some percentages will not total 100 due to rounding off; 2) for each period, values represent the average percentages in each category of this time span; 3 ) in Greece, the data in the last column (C-A) refers to the difference between the decade of 1991-2002 and that of 1982-1987, or rather, represents C-B and not C-A; 4) detailed distributions can be consulted in Freire, 2006, Appendix III, or can be furnished by the author upon request; 6) weighted data.

Sources: see figure 2.1; and Spain 1979 (not 1978) and 1982 in Torcal and Medina, 2002: 64; for all the countries, except Portugal, in 2002 the source is Eurobarometer 57.1; Portugal 2002, Comparative Study of Electoral Systems, Module 2.

1970s and the 1980s, and between 1970 and 1990-2002. It should be noted that, by using average percentages per decade, we are purging the averages of some situational effects: those of shorter span.

One last note before continuing to the analysis of table 2.2. If we were to analyse the annual variations, the results would be extremely vulnerable, not 
only to situational effects, but also to errors in measurement (that is, related to methods of sampling and data collection and to the processes of inquiry tout court). For this reason, for the data presented in tables 2.3 and 2.4 below, which is based upon annual variations, we define a change as relevant only when superior to $5 \%$. Using variations in averages per decade (table 2.1), it does not seem necessary to us to take the same precaution and, therefore, we define a relevant change as being higher than half the previous value, or in other words, above $2.5 \%$.

Comparing the distributions of voters' ideological orientations grouped into three categories (left, right and centre), between the decades of 1970 and 1980, and considering only the relevant changes (more than $2.5 \%$ ), we reached the following conclusions. On the one hand, in a majority of countries (three), there was a reflux of ideological centrism (average: $-8.9 \%$ ); however, in two countries, there was an influx of ideological centrism (average: $+3.9 \%$ ). On the other hand, the influxes and refluxes of the left and right positions were pretty much balanced (both in terms of the number of cases and in terms of the average changes). Comparing ideological alignments between the decade of 1970 and the period 1991-2002, a very similar picture was found. In a majority of countries (five), there was a growth in ideological centrism, but in four countries, the reverse was true. However, on average, the decrease in ideological centrism $(-6.6 \%)$ was higher than the increase $(+5.2 \%)$. Again, the influxes and refluxes of the left and right positions were pretty much balanced (both in terms of the number of cases and in terms of the average changes). Thus, we can conclude that there are no general trends either in terms of the growth or the decrease of ideological centrism. ${ }^{7}$

As we had said above, the (systematic and linear) growth of ideological centrism can be interpreted as an indicator of the increase in the irrelevance of the left-right division. However, whether the absence of general tendencies in terms of evolution in the direction of ideological centrism, or above all the flux and reflux that is evident between the different countries and time periods, the theory of the growing irrelevance of the left-right division is not corroborated. On the contrary, such evolution seems above all to show adjustments of voters' ideological alignments to the alterations of the contextual conditions; that is, to the existing political and electoral situations.

7 There are some differences between the results presented in table 2.2 and identical results presented in Freire, 2004b. These differences are due to the weighting procedures used in the present article. However, those differences do not impact the basic general conclusions. 


\section{Ideological alignments and political conjunctures}

We see that the ideological orientation of the voters seems, in many cases, to accompany the evolution of political conjunctures in the three decades being analysed. However, the methodology used-comparison of the average values between the three decades - is not the most adequate to verify the existence of an eventual vulnerability of voters' left-right orientations to existing short-term factors. First, because the use of measurements per decade obscures those short-term fluctuations. Second, because in using measurements per decade and, above all, comparisons between three decades, we are already entering into mid- to long-term changes, which will be able to be dependent on the entrance of new "cohorts" in the electorate. In other words, in the comparison of the evolution of ideological orientations between decades, it becomes doubtful whether or not the eventual changes are owed to fundamental alterations in the predispositions of the electors, or to the entrance of young individuals (above the age of 18) into the adult population. For this reason, in the present section we intend to evaluate to what degree the individuals' left-right alignments are or are not vulnerable to existing situational short-term factors. For a theoretical basis of this approach, which for reasons of space can not be presented here, see Freire, 2004b: 227-229.

In tables 2.3 and 2. 4, we present the variations in ideological alignments (left, centre and right) between the different pairs of consecutive years for which we have collected information. This is the appropriate method to assess eventual short-term situational effects upon ideological orientations and, therefore, to assess the degree to which these can be effectively considered to be long- or short-term factors (Freire, 2004b: 227-229). As we have said above, taking into account the errors which are always associated with studies based upon different samples (errors of sampling and of inquiry), we define as relevant variables between any two points of time only those whose values are higher than $5 \%$.

The empirical evidence presented in tables 2.3 and 2.4, which for reasons of space we can not analyse in detail, point to three fundamental conclusions. First, in any country there is always a certain vulnerability to ideological orientations and short-term factors. This data is congruent with the "revisionist theories of partisan identification" (Fiorina, 1981), which perceives this as being a condensing element with relation to the long- and short-term effects.

Second, in $74 \%$ or more of all cases, ideological orientations are shown to be stable. Spain, Greece and Portugal are the only three exceptions: in these countries, either volatility predominates stability in terms of the ideological orientations of the voters (Greece: $52 \%$ ), the two are ex aequo (Portugal: $50 \%$ ), or the level of volatility is at least much higher than in the other countries (Spain: 46\%). In each one of all the other eight countries, as was said before, 
Table 2.3 Short-term shifts in left-right alignments in Europe between 1976 and 2002 (I) (difference in percentages)

\begin{tabular}{|c|c|c|c|c|c|c|c|c|c|}
\hline & $\begin{array}{l}1978 / \\
1976\end{array}$ & $\begin{array}{c}1982 / \\
1978\end{array}$ & $\begin{array}{l}1984 / \\
1982\end{array}$ & $\begin{array}{l}1985 / \\
1984\end{array}$ & $\begin{array}{l}1987 / \\
1985\end{array}$ & $\begin{array}{l}1991 / \\
1987\end{array}$ & $\begin{array}{c}1994 / \\
1991\end{array}$ & $\begin{array}{c}1999 / \\
1994\end{array}$ & $\begin{array}{r}2002 / \\
1999\end{array}$ \\
\hline \multicolumn{10}{|l|}{ Portugal } \\
\hline Left & - & 5.8 & -3.1 & -2.5 & -4.1 & 2.5 & 3.6 & -5.7 & 5.6 \\
\hline Centre & - & -15.8 & 5.6 & 1.0 & -1.2 & 3.5 & 2.8 & 8.2 & -14.6 \\
\hline Right & - & 9.9 & -2.5 & 1.5 & 5.3 & -6.0 & -6.4 & -2.5 & 9 \\
\hline \multicolumn{10}{|l|}{ Spain } \\
\hline Left & - & 4.1 & 3.0 & -6.1 & 7.1 & 3.3 & -8.6 & -8.2 & 8.5 \\
\hline Centre & - & -10.5 & 0.0 & 2.5 & -0.3 & -1.4 & -0.8 & 6.4 & 2.4 \\
\hline Right & - & 6.2 & -2.9 & 3.7 & -6.9 & -1.9 & 9.4 & 1.8 & -10.9 \\
\hline \multicolumn{10}{|l|}{ Greece } \\
\hline Left & - & - & -6.6 & 4.0 & -8.0 & -6.5 & 0.1 & 0.3 & -4.4 \\
\hline Centre & - & - & 4.4 & -6.4 & 1.1 & 3.2 & 5.9 & -11.2 & 13.2 \\
\hline Right & - & - & 2.2 & 2.4 & 6.9 & 3.3 & -6.0 & 10.8 & -8.6 \\
\hline \multicolumn{10}{|l|}{ France } \\
\hline Left & 0.9 & -1.4 & -5.8 & -2.3 & 6.3 & -0.5 & 2.8 & 1.5 & -5.3 \\
\hline Centre & -3.1 & 3.2 & 1.8 & 0.5 & 1.0 & 2.2 & -8.6 & 1.4 & 1.2 \\
\hline Right & 2.2 & -1.7 & 3.9 & 1.8 & -7.3 & -1.6 & 5.7 & -2.9 & 4.1 \\
\hline \multicolumn{10}{|l|}{ GB } \\
\hline Left & 1.8 & 1.0 & 0.7 & -1.6 & -1.4 & 4.0 & 3.8 & 0.8 & 3.2 \\
\hline Centre & 2.9 & 1.7 & -0.5 & -0.6 & -0.7 & 2.1 & 0.0 & 1.1 & 2.3 \\
\hline Right & -4.7 & -2.7 & -0.2 & 2.2 & 2.1 & -6.0 & -3.9 & -1.9 & -5.5 \\
\hline \multicolumn{10}{|c|}{ Germany } \\
\hline Left & -2.0 & 6.9 & 3.1 & -2.0 & 2.5 & -5.4 & 7.1 & -0.7 & -2.4 \\
\hline Centre & 3.1 & -1.1 & -2.1 & 1.6 & -2.2 & 2.6 & 5.8 & 0.6 & 0.5 \\
\hline Right & -1.0 & -6.0 & -0.9 & 0.5 & -0.5 & 2.9 & -12.9 & 0.0 & 2.1 \\
\hline
\end{tabular}

Notes: 1) for each pair of years, in each country, the values represent, for each category (left, centre and right) the differences in percentages between the most recent and the least recent year of the pair; 2) see the detailed distributions in Freire, 2006, Appendix III; 3) GB- Great Britain; 4) weighted data.

Sources: see figure 2.1 .

stability is the main feature in at least $74 \%$ of the observations. Furthermore, Belgium is the only country where volatility in left-right orientations reaches $26 \%$, because in the remaining seven countries the levels of volatility in left-right alignments are always bellow $1 / 4$ of the total number of cases. In other words, except for the "new" southern European democracies, the stability is generally the predominant trace of left-right alignments, as has been argued by the traditional models of electoral behaviour (Freire, 2004b: 227-229). ${ }^{8}$

Third, there is a greater vulnerability of ideological identities to existing short-term situational factors in the case of the "new" democracies of Southern

8 There are some differences between the results presented in two tables included herein (tables 3 and 4) and identical results presented in Freire, 2004b. These differences are due to the weighting procedures used in the present article. However, those differences do not impact the basic general conclusions. In fact, quite the opposite is true: the conclusions are strengthened. 
Table 2.4 Short-term shifts in left-right alignments in Europe between 1976 and 2002 (II) (difference in percentages)

\begin{tabular}{lrrrrrrrrr}
\hline & $1978 /$ & $1982 /$ & $1984 /$ & $1985 /$ & $1987 /$ & $1991 /$ & $1994 /$ & $1999 /$ & $2002 /$ \\
& 1976 & 1978 & 1982 & 1984 & 1985 & 1987 & 1991 & 1994 & 1999 \\
\hline Italy & & & & & & & & & \\
$\quad$ Left & -0.6 & -3.4 & 0.6 & -2.5 & -1.2 & -2.3 & -7.9 & 6.5 & 0.9 \\
$\quad$ Centre & 5.0 & -1.5 & -1.0 & 2.3 & 2.1 & -0.5 & -4.3 & -6.5 & -2.4 \\
$\quad$ Right & -4.4 & 4.8 & 0.5 & 0.2 & -0.9 & 2.8 & 12.2 & 0.1 & 1.4 \\
$\begin{array}{l}\text { Netherlands } \\
\quad \text { Left }\end{array}$ & 10.0 & -2.5 & 1.0 & 0.8 & -1.7 & -1.8 & 0.7 & -1.1 & -0.9 \\
$\quad$ Centre & -1.2 & 1.2 & 1.4 & 0.6 & 2.5 & 1.9 & -3.0 & -4.3 & 8.8 \\
$\quad$ Right & -8.8 & 1.3 & -2.4 & -1.4 & -0.8 & -0.1 & 2.3 & 5.4 & -8.0 \\
Denmark & & & & & & & & & \\
$\quad$ Left & -1.6 & -0.7 & 1.9 & 1.5 & 1.1 & -2.0 & 3.0 & -4.0 & 6.0 \\
$\quad$ Centre & -1.7 & 2.0 & -8.6 & 0.7 & -4.5 & 0.6 & -2.0 & 2.7 & -6.1 \\
$\quad$ Right & 3.3 & -1.3 & 6.6 & -2.1 & 3.4 & 1.4 & -1.0 & 1.3 & 0.1 \\
Belgium & & & & & & & & & \\
$\quad$ Left & -2.0 & 3.5 & 0.5 & 1.3 & 2.2 & -2.0 & 9.0 & -13.0 & 13.0 \\
$\quad$ Centre & -1.5 & 4.0 & 2.6 & -3.6 & 3.6 & 1.8 & -7.3 & 13.7 & -7.1 \\
$\quad$ Right & 3.6 & -7.5 & -3.1 & 2.3 & -5.9 & 0.3 & -1.7 & -1.4 & -5.2 \\
Ireland & & & & & & & & & \\
$\quad$ Left & -1.2 & 0.3 & -2.0 & 1.0 & -1.2 & 10.1 & -5.0 & 2.4 & -2.8 \\
$\quad$ Centre & -1.8 & -2.2 & 1.8 & -0.2 & -0.5 & 1.4 & -0.6 & 0.1 & -1.8 \\
$\quad$ Right & 3.0 & 1.9 & 0.3 & -0.8 & 1.6 & -11.4 & 5.5 & -2.6 & 4.7 \\
\hline
\end{tabular}

Notes: see table 2.3 .

Sources: see figure 2.1; for all countries, in 2002 the source is Eurobarometer 57.1.

Europe. Therefore, the positive correlation between the longevity of the democracies and the stability of ideological orientations is quite strong. Such a high intensity relationship reveals that, in the new democracies, the ideological categories need to be gradually recognised by the electorate, since they are, at least in the first decades of the regime's life, more volatile. In other words, time is needed for the voters to recognise the ideological categories and consolidate their perceptions about the respective meaning.

\section{Concluding notes}

Of the analyses developed in relation to the evolution of ideological identities between the decade of 1970 and 2002, some observations stand out. First, between 1976 and 2002, the percentage of individuals who positioned themselves on the left-right scale increases (Portugal, Spain and Denmark) or remains stable (Great Britain, Germany, Holland, Greece, Belgium and Ireland) in the gross majority of cases analysed: nine in eleven. Therefore, the evolution of left-right orientations do not present any general trend whatsoever and, as a result, depends in large part upon factors which are specific to each country. We are inclined to think that these factors refer, namely, to oscillations in the ideological polarisation on the level of partisan offer, given that, at 
least in synchronistic terms, this is the most important factor in explaining the impact of the three components (value/issue, partisan and social) of citizens' left-right self-placement (Freire: 2004b).

Second, as expected, the erosion of ideological identities never reaches the new democracies of Southern Europe. In other words, in these countries the percentage of individuals who identify themselves with a left-right division are growing (Portugal and Spain) or stabilising (Greece). However, this is not an exclusive sign of the new democratic regimes: in various older democracies there is an increase or a stabilisation in the identification of citizens with the left-right axis.

Third, the evolution of ideological identities, between 1976 and 2002, contradicts the theories about the decline of ideology: in the majority of countries, a stabilisation or an increase in the percentage of individuals who position themselves on the left-right scale is evident. Even if we withdraw the new democracies of Southern Europe from the group (since, in these cases, the ideological identities were in the process of being formed/consolidated), given that in this subgroup the trends are always increasing or stabilising, we are left with eight countries of which six do not show any decline in the identification of the citizens with the division between the left and the right (or at least the "trends" found in these six countries are so weak that we should rather speak of stabilisation than of a decrease or an increase in the percentages of citizens' left-right self-placement). Furthermore, the evolutions in terms of ideological alignments (left, centre and right) in the various European countries being analysed also do not corroborate the theories of the "end of ideology". First, because there is generally no systematic or linear increase of ideological centrism which could be considered an indicator of the growing irrelevance of the left-right division, but instead fluxes or refluxes (across time and countries) that seem to follow the changes in the political conjunctures. Second, since there is no general trend whatsoever in terms of ideological alignments, but rather a diversity of evolutions relevant to the countries and time periods being analysed.

Fourth observation: in light of the average of the remaining European countries being analysed, the divergence between the new democracies of Southern Europe and the other analysed European countries has come to be clearly reduced. In the decades of 1980 and 1990-2002, the differences between the new democracies of Southern Europe and the others are already much less pronounced, in terms of the recognition of the left-right division. ${ }^{9}$ Nevertheless, in the period 1990-2002 the ideological identities in Portugal, Spain and Greece are even lower than the European average, above all in the case of Portugal.

As a fifth point, there must be a distinction made between the cases of Greece and the two other democracies of Southern Europe. Whether early in the decade of the 1980s, or in the period of 1990-2002, Greece is and has always been more in line with the older European democracies in terms of extension of the ideological identities among its citizens. The greater convergence of Greece 
with the rest of Europe, compared to Portugal and Spain, also seems evident in terms of evolutionary trends: ideological identities in Greece seem to have stabilised, while in Portugal and Spain there was an increase in such identification during those periods; however, the absence of data for the 1970s prevent us from having a complete perspective with reference to the case of Greece. Such signs have been interpreted throughout the present work as being owed to the following factors: first, the shorter dictatorial interregnum in Greek society; second, the continuity of various political objects (leaders, parties and ideological trends) both before and after the regime of the colonels.

In reference to the stability versus volatility of ideological identities, there are three fundamental conclusions of the analysis developed in the present chapter. First, the distributions of the ideological identities are always, to a greater or lesser degree, vulnerable to short-term factors. Second, in spite of this, those which are predominant in the ideological orientations are the long-term signs. In other words, except in Spain, Greece and Portugal, in the large majority of cases ( $76 \%$ of the observations or more), the stability of left-right alignments prevails vis-à-vis their vulnerability to existing short-term political and electoral effects. Therefore, in line with the revisionist theories of partisan identification, which defend that this element condenses the long-and short-term effects, we can conclude that in the case of left-right orientations there are also two types of effects that are noticed. However, except in the new democracies (at least on the mass level), left-right alignments are above all a long-term psychological orientation that helps citizens to cope with the complexities of the political universe. Third, the influence of short-term factors upon ideological orientations is another predominant feature associated with the new democracies of Southern Europe. Only in the new democracies of Southern Europe is the vulnerability of citizens' left-right alignments to existing short-term influences present in $46 \%$ or more of the cases being analysed.

To review, the recognition and the stability of the left-right orientations among the electorate are clearly two elements which differentiate the new democracies of Southern Europe from the rest of Western Europe. In the new polyarchies, it is necessary for time to pass before the extension of the recognition of the ideological left-right categories which are evident in the older systems can be achieved. On the other hand, left-right alignments are not yet

9 In terms of the averages for the decade of the 1980s and for the period 1990-2002, the percentage of individuals who position themselves on the left-right scale in the "new Southern Europe" are as follows: Portugal: 74.0 and 78.0; Spain: 75.0 and 81.0; Greece: 85.0 and 81.0, respectively for the years 1980 and 1990-2002. In the remaining eight European countries, the corresponding average percentages were the following: 87.3 and 84.9 , respectively for the decades of the 1980s and for 1990-2002. There are some differences between these results and identical ones presented in Freire, 2004b and 2005. These differences are due to the weighting procedures used in the present article. However, those differences do not impact the basic general conclusions. 
as consolidated in the new regimes, as compared to the older ones, given that such orientations are clearly more volatile in the new governments.

\section{Annex: different formats of the left-right scale}

\begin{tabular}{|c|c|c|}
\hline Studies & $\begin{array}{l}\text { Self-placement on the left-right } \\
\text { scale }\end{array}$ & Categorisation \\
\hline Bacalhau, 1978, 1982 and 1984 & $\begin{array}{l}\text { When they talk about politics, } \\
\text { people usually talk about left and } \\
\text { right, as we already see regarding } \\
\text { the parties. Can you place yourself } \\
\text { on this familiar scale? }\end{array}$ & $\begin{array}{l}1 \text { - Left } \\
\text { to } \\
10-\text { Right }\end{array}$ \\
\hline $\begin{array}{l}\text { Barnes, McDonough and Pina, } \\
1985\end{array}$ & $\begin{array}{l}\text { For many people, political attitudes } \\
\text { are of the left or the right. This } \\
\text { scale goes from the left to the } \\
\text { right. Think about your own } \\
\text { political attitudes. Where would } \\
\text { you place yourself? Please mark } \\
\text { an X in the appropriate box. }\end{array}$ & $\begin{array}{l}1 \text { - Left } \\
\text { to } \\
10-\text { Right }\end{array}$ \\
\hline $\begin{array}{l}\text { PCSE: Political Culture in } \\
\text { Southern Europe } 1985\end{array}$ & $\begin{array}{l}\text { We have seen that in politics } \\
\text { people use normally the } \\
\text { expressions "left" and "right". On } \\
\text { this card there are boxes ranging } \\
\text { from the left to the right. In which } \\
\text { box would you place yourself? }\end{array}$ & $\begin{array}{l}1 \text { - Left } \\
\text { to } \\
10-\text { Right }\end{array}$ \\
\hline $\begin{array}{l}\text { EES: European Election Study } \\
1999\end{array}$ & $\begin{array}{l}\text { In political matters people talk of } \\
\text { "the left" and "the right". What is } \\
\text { your position? Please indicate your } \\
\text { views using any number on a } \\
10 \text {-point-scale. On this scale, } \\
\text { where } 1 \text { means "left" and } 10 \\
\text { means "right," which number best } \\
\text { describes your position? }\end{array}$ & $\begin{array}{l}1 \text { - Left } \\
\text { to } \\
10-\text { Right }\end{array}$ \\
\hline $\begin{array}{l}\text { WVS: World Values Survey } \\
\text { 1990, and EVS: European } \\
\text { Values Study } 1999\end{array}$ & $\begin{array}{l}\text { In political matters, people talk of } \\
\text { "the left" and the "the right". How } \\
\text { would you place your views on this } \\
\text { scale, generally speaking? }\end{array}$ & $\begin{array}{l}1 \text { - Left } \\
\text { to } \\
10-\text { Right }\end{array}$ \\
\hline EB: Eurobarometers & $\begin{array}{l}\text { In political matters people talk of } \\
\text { "the left" and "the right". How } \\
\text { would you place your views on this } \\
\text { scale? }\end{array}$ & $\begin{array}{l}1 \text { - Left } \\
\text { to } \\
10-\text { Right }\end{array}$ \\
\hline $\begin{array}{l}\text { CSES: Comparative Study of } \\
\text { Electoral Systems }\end{array}$ & $\begin{array}{l}\text { In politics people sometimes talk of } \\
\text { left and right. Where would you } \\
\text { place yourself on a scale from } 0 \text { to } \\
10 \text { where } 0 \text { means the left and } 10 \\
\text { means the right? }\end{array}$ & $\begin{array}{l}0-\text { Left } \\
\text { to } \\
10-\text { Right }\end{array}$ \\
\hline
\end{tabular}

Sources: Bacalhau, 1994: 58 and 304; Barnes, McDonough and Pina, 1985: 699-700, note 5; PCSE, 1985; WVS, 1990, and EVS, 1999; EBTF 1970-1999; EB 57.1 (2002); EES 1999; CSES. 


\section{References}

Bacalhau, Mário (n. d.), Eanes, A Solução? Inquérito à Situação Política, Lisbon, Heptágono.

Bacalhau, Mário (1994), Atitudes, Opiniões e Comportamentos Políticos dos Portugueses, 1993, Lisbon, published by Mário Bacalhau and Tom Bruneau.

Barnes, Samuel H. (2002), "Left and right in old and new democracies", Central European Political Science Review, 3 (7), pp. 6-15.

Barnes, Samuel H., Peter McDonough, and António L. Pina (1985), “The development of partisanship in new democracies: the case of Spain", American Journal of Political Science, 29, pp. 695-720.

Barroso, José Durão Barroso, and Jonas Condomines (1985), “A dimensão esquerda-direita e a competição partidária na Europa do Sul (Portugal, Espanha, Grécia)", Revista de Ciência Politica, 1, pp. 35-60.

Bell, Daniel (1960, 2000), The End of Ideology. On the Exhaustion of Political Ideas in the Fifties, Harvard, Harvard University Press.

Bobbio, Norberto (1994, 1995), Direita e Esquerda, Lisbon, Editorial Presença.

Budge, Ian, and Hans-Dieter Klingemann (2001), “Finally! Comparative over-time mapping of party policy movement", in Ian Budge et al. (eds.), Mapping Policy Preferences. Estimates for Parties, Electors and Governments 1945-1998, Oxford, Oxford University Press, pp. 19-50.

Campbell, Angus, et al. (1960, 1980), The American Voter, Chicago, Chicago University Press.

Converse, Philip (1964), "The nature of belief systems in mass publics", in David E. Apter (ed.), Ideology and Discontent, New York, Free Press, 206-261.

Converse, Philip (1969), “Of time and partisan stability”, Comparative Political Studies, 2, pp. 139-171.

Dalton, Russell J. (2000), “The decline of party identifications", in Russell J. Dalton and Martin P. Wattenberg (eds.), Parties without Partisans. Political Change in Advanced Industrial Democracies, Oxford, Oxford University Press, pp. 19-36.

Dalton, Russell J., and Martin P. Wattenberg (eds.) (2000), Parties Without Partisans. Political Change in Advanced Industrial Democracies, Oxford, Oxford University Press.

Eatwell, Roger (1999, 2003), "Introduction: what are political ideologies", "Conclusion: the 'end of ideology'", in Roger Eatwell and Anthony Wright, Contemporary Political Ideologies, London, Continuum, pp. 1-22 and 279-290.

Fiorina, Morris P. (1981), Retrospective Voting in American National Elections, Haven, Yale University Press.

Franklin, Mark, et al. (eds.) (1992), Electoral Change. Responses to Evolving Social and Attitudinal Structures in Western Countries, Cambridge, Cambridge University Press.

Freire, André (2001), Modelos do Comportamento Eleitoral. Uma Breve Introdução Crítica, Oeiras, Portugal, Celta Editora.

Freire, André (2003), "Pós materialismo e comportamentos políticos: o caso português em perspectiva comparada", in Jorge Vala, Manuel Villaverde Cabral, and Alice 
Ramos (eds.) Valores Sociais. Mudanças e Contrastes em Portugal e na Europa, Lisbon, ICS/Imprensa de Ciências Sociais, pp. 295-362.

Freire, André (2004a), "Voto por temas: orientações perante as políticas públicas, desempenho do governo e decisão eleitoral", in André Freire, Marina C. Lobo, Pedro C. Magalhães (eds.), Portugal a Votos. As Eleições Legislativas de 2002, Lisbon, ICS/Imprensa de Ciências Sociais.

Freire, André (2004b), O Significado da Divisão entre Esquerda e Direita. Portugal, Espanha e Grécia em Perspectiva Comparativa (Phd thesis), Lisbon, Instituto de Ciências Sociais da Universidade de Lisboa.

Freire, André (2005), “Identidades ideológicas e partidárias na Europa: Portugal, Espanha e Grécia em perspectiva comparativa", Sociologia, Problemas e Práticas, 47, pp. 11-34.

Freire, André (2006), Esquerda e Direita na Política Europeia. Portugal, Espanha e Grécia em Perspectivas Comparada, Lisbon, ICS/Imprensa de Ciências Sociais.

Fuchs, Dieter, and Hans-Dieter Klingemann (1990), "The Left-Right Schema”, in M. Kent Jennings et al., Continuities in Political Action, Berlin, de Gruyter, pp. 203-234.

Fukuyama, Francis (1989), "The end of history", The National Interest, 16.

Giddens, Anthony (1994, 1996), Más Allá de la Izquierda y la Derecha, Madrid, Ediciones Cátedra.

Giddens, Anthony $(1998,1999)$, Para Uma Terceira Via, Lisbon, Editorial Presença.

Giddens, Anthony (2000), The Third Way and its Critics, Cambridge, Polity Press.

Gunther, Richard, and Larry Diamond (2003), "Species of political parties: a new tipology", Party Politics, 9 (2), pp. 167-199.

Gunther, Richard, and José R. Montero (2001), “The anchors of partisanship: a comparative analysis of voting behaviour in four Southern European countries", in Nikiforos Diamandouros and Richard Gunther (eds.), Parties, Politics, and Democracy in New Southern Europe, Baltimore, The John Hopkins University Press. pp. 83-152.

Heywood, Andrew (1992, 2003), Political Ideologies. An Introduction, Basingstoke, Palgrave Macmillan.

Inglehart, Ronald, and Hans-Dieter Klingemann (1976), “Party identification, ideological preference and the left-right dimension among western mass publics", in Ian Budge et al. (eds.), Party Identification and Beyond. Representations of Voting and Party Competition, London, John Wiley \& Sons, pp. 243-276.

Klingemann, Hans-Dieter, and Dieter Fuchs (eds.) $(1995,1998)$, Citizens and the State, Oxford, Oxford University Press.

Knutsen, Oddbjørn (1998), "Europeans move towards the centre: a comparative longitudinal study of the left-right self-placement in Western Europe", International Journal of Public Opinion Research, 10 (4), pp. 292-316.

Laponce, J. A. (1981), Left and Right. The Topography of Political Perceptions, Toronto, University of Toronto Press.

Lipset, Seymour M. (1981, 1987), “El fin de toda ideologia?” and “Un concepto y su historia: el fin de la ideología”, in Seymour M. Lipset, El Hombre Político. Las 
Bases Sociales de la Política, Madrid, Editorial Tecnos, pp. 357-372 and 420-448.

Luhmann, Niklas (1982), The Differentiation of Society, New York, Columbia University Press.

Mair, Peter (1997, 1998), Party System Change. Approaches and Interpretations, Oxford, Oxford University Press.

Niemi, Richard G., et al. (1985), “Testing the converse partisanship model with new electorates", Comparative Political Studies, 18, pp. 300-322.

Sani, Giacomo, and José R. Montero (1986), “El espectro político: izquierda, derecha y centro", in Juan Linz and José R. Montero (eds.), Crisis y Cambio. Electores y Partidos en la España de los Años Ochenta, Madrid, Centro de Estudios Constitucionales, pp. 155-200.

Schmitt, Hermann, and Sören Holmberg (1995, 1998), "Political parties in decline?", in Hans-Dieter Klingemann and Dieter Fuchs (eds.) (1995, 1998), Citizens and the State, Oxford, Oxford University Press, pp. 95-133.

Torcal, Mariano, and Lucía Medina (2002), “Ideologia y voto en España 1979-2000: los processos de reconstrucción racional de identificación ideológica", Revista Española de Ciência Política, 6, pp. 57-96. 



\title{
Political participation \\ The Portuguese case from a European comparative perspective
}

\author{
José Manuel Leite Viegas and Sérgio Faria
}

\section{Political participation and representation}

Political participation and representation are both structural factors of the present-day democratic order. Participation guarantees the conditions for the involvement and inclusion of individuals in the processes that constitute power and, indirectly, in the decision-making processes. Representation establishes institutional harmony within which pluralism finds expression, and debate and political dialogue are pursued.

In the light of this interpretation, it seems an analytically biased exercise to consider modern democracy solely on the basis of one of these aspects, to the neglect of the other. In other words, in the way that the democratic order is understood here, it makes little sense to support an approach based exclusively on one of the terms of the democratic equation, participation or representation, as if the choice of one of these terms, to the detriment of the other, were obligatory or inevitable or as if one of them was categorically subordinated to the other. As the position stated above implies, the question is of a different order and concerns precisely the complementary nature of these two factors, since political participation and representation do not just involve each other mutually and reciprocally but also intrinsically depend on each other. In other words, at the political level, representation takes places, though, via participation, different options and various kinds of support emerge.

This does not mean, however, that on the level of the theories of democracy this is the only conception of the issue (Held, 1987). On the contrary, it is worth noting that one of the threads of debate that has most enlivened discussion on the democratic phenomenon was structured around the supposed antagonism between representative democracy and participative democracy (see Bobbio, 1984, for a summary). Moreover, this debate still appears today, although a growing trend can be discerned towards the advancement of analytical matrices that, on a conceptual plane, consider both factors in combination. 
The result of this is that, within the framework of the democratic system, participation and representation are not terms that imply a kind of dualism, but elements that constitute a duality. In other words, participation and representation are both conditions of the modern democratic order. This is equivalent to saying that the assumption of democracy presupposes and is confirmed on two distinct levels: firstly, in the act of participating in the choice of representatives and an array of other forms of action that may influence these representatives and, secondly, in the existence of a representative institutional complex capable of guaranteeing that public policies will be pursued.

From another perspective, it is also worth recognising that participation is not a synonym of self-government. Contemporary socio-political compositions, in the form of the state, involve the existence of bodies that are functionally directed towards defining and pursuing orientations that, on the principle of a political mandate, bind the whole community, so as to allow a significant array of social processes to be agreed on and regulated.

This is not intended to mean that, in the context of the present times, democracy is the result of a perfect balance between political participation and representation. One of the problems at the core of democracy is precisely the tension arising from the form that each of these principles assumes. This is because participation and representation limit and condition each other, despite their mutual dependence (Corcoran, 1983; Diamond, 1996; Przeworski, 1988; Schmitter, 1996; and Schmitter and Karl, 1996).

In the mid-seventies, in The Crisis of Democracy, Huntington, Crozier and Watanuki (1975) envisaged increased political tension arising from the state's inability to meet the citizens' increasing demands. In practice, this tension was the result of a contradiction generated by democracy's own performance: the expansion of social rights and the increase in the powers of political participation produced desires and expectations to which the state could not respond, specifically for reasons of budget limitations.

At approximately the same date, Habermas (1976) diagnosed a set of symptoms that suggested a different situation. According to the author, the issue was not so much the increased demands on the political and administrative system as the transformation of those demands. Thus, the problem was not so much one of budget possibilities - i.e. a problem of the costs arising from higher social demands on the state, which could possibly be solved by a change in fiscal policy. Rather, the problem was the discrepancy between the orientations of the bodies providing political representation and those of certain social segments - in particular the new middle classes, with more education and with reference values in accordance with those pursued by the new social movements - , which had implications for the sustainability and legitimacy of the established order.

In empirical terms, the response to these questions requires that analyses are carried out at various levels: not only at the level of the institutions, 
political processes, and symbolical and ideological transformations, but also of the agents and their forms of political involvement, specifically the forms of political participation.

At this last level, the contribution to be made to clarifying the overall problems of the operation of democracy, mentioned above, involves a response to questions such as: is there, in fact, a contraction in the institutional participation by individuals, in particular through political parties? Do more highly qualified agents produce more differentiated and dispersed forms of political participation? Do the new forms of participation discourage the formation of collective action or not? Do these "new forms of political participation" compensate for the fall in traditional participation?

The theoretical considerations formulated above include a comparative analysis of political participation, based on the Portuguese case. This text, however, which is obviously positioned at the level of individuals as political agents, is directed towards empirically more circumscribed objectives. The intention is to compare political participation in Portugal with that in other European countries, both overall and, very particularly, in terms of the forms and types of political participation.

The basis of this work was a survey carried out in different European countries under an international research programme on citizenship and political involvement. Of the 12 European countries that the European investigation covered, eight were selected for this analysis, on the basis of geographical criteria and, also, because they define different socio-cultural realities: the Nordic countries of Sweden and Denmark; the western central European countries of the Netherlands and western Germany; the southern countries of Portugal and Spain; and, finally, the eastern countries of Moldova and Romania.

\section{Forms of political participation}

As mentioned above, participation is one of the basic elements of citizenship and the political system in democratic government. Within this type of political order, the selection of rulers through the ballot box is one of the most important ways to participate. However, after a phase in which the dominant ideas restricted the phenomenon of political participation to involvement in the electoral process, the studies in this field have come to recognise that there are other forms of political participation, despite the different interpretations of their modalities and types.

For this reason, it is appropriate, first of all, to define what is understood by political participation in systems of representative democracy. According to the seminal view of Verba and Nie (1972: 2), "political participation refers to activities carried out by citizens, which, to a greater or lesser degree, are directly aimed at influencing the choice of rulers and the decisions that they 
take". That said, in this interpretation it is important to stress, in the first place, that political participation relates to the citizens, i. e. those who do not directly take part in political decision-making and, in the second, that political participation is necessarily directed at the rulers, i. e. the political power-holders.

The greatest virtue of this definition was to have broadened the concept of political participation, which had hitherto tended to be restricted to electoral mobilisation. Even so, it is to be noted that the international research that produced the publication Political Action. Mass Participation in Five Western Democracies (Barnes et al., 1979) proceeded to revise the concept of political participation, introducing a new breadth. The authors took "non-conventional" forms of participation into account, in particular protest participation, calling attention to the fact that these forms do not necessarily imply a rejection of the democratic order, such as could be understood in Verba and Nie (1972). The explosion of protest and revolt in Western democracies in the 60s was at the root of this theoretical slant, as Barnes et al. (1979) recognised.

For Verba and Nie (1972), the aim of political participation was to influence decisions made by the political bodies and the personalities that hold a certain power in the political system. On this plane, the concept of political participation was also broadened with the work of Barnes et al. (1979) in that they considered the following as forms of political participation: boycotts on certain products, squatting, and damage to private entities' property, if integrated into forms of protest. In these cases, the action is directed at companies and organisations in civil society and not directly at rulers.

The latter interpretation of political participation has gained greater importance in recent years, in particular for authors who argue that there is no reduction in participation but rather a transformation of political culture that is reflected in an increase in new forms and modalities of participation (Inglehart, 1997; Norris, 1999). According to this view, these new forms of participation compensate for the decline in the institutionally-framed, traditional forms.

It is worth saying a little more about these new forms of participation, both with regard to the actual forms they take and the socio-cultural transformations in developed countries that are the basis of these changes.

The new forms of participation, which include, for example, the purchase or boycotting of certain products and the use of the internet to express political opinions, are different in significant aspects from both institutional participation and the (traditional) forms of protest. The latter (e.g. strikes or demonstrations) are characteristically collective, recurrent and continuing demonstrations - from the organisational aspect and in their underlying identities. The new forms of participation, however, are characterised by their individual expression (at least at the start) and sporadic or occasional action (directed at a specific object and moment) and, in most cases, do not involve 
loyalties to a group of members with permanent forms of organisation. In addition, the new forms of participation are characterised by their not being directed exclusively at the organs of political power, since in some cases they are aimed at companies or other civil society institutions which, despite their status, have great power to act.

How can the rise and expansion of these new forms of participation be explained, socially and politically? Certain social and cultural factors, characteristic of the democracies in the most developed countries lie at the base of these forms of participation. The following are worthy of note: the higher educational levels of the populations, the expansion of technical and scientific occupations, the spread of new information technology, the increasingly individualised ways of life in the big cities, with the weakening of traditional social and political identities, and the cultural transformations commonly called the crisis of ideologies.

This is the background that favours the emergence of citizens who are more independent and have a greater knowledge of social and political problems, i. e. who are less inclined to delegate the protection of their interests or values to people or organisations, less inclined to accept global ideologies, more instrumental in political action, and more conscious of the political role of organisations and the powers of civil society, to the disadvantage of the powers of the state (Bourdieu, 1984).

In the first point we intend to provide a comparative analysis of citizen involvement in the different forms of participation. In accordance with the theoretical developments presented briefly above and the empirical work in this area, these forms are organised into five types: "electoral participation", "participation in institutions of political representation", "participation in other types of institution", "protest participation" and "new forms of participation". Table 3.1 shows the indicators for each form of participation and the percentages relating to the actual exercise of it in each country.

A first overall reading indicates that, in Portugal, public and political participation in the different forms is almost always below that of other countries, with the exception, in certain forms of participation, of the Eastern European countries: Moldova and Romania.

Electoral participation is the form that has been most studied in Portugal, which is part of the trend towards increased abstention that has been apparent since the mid-90s (Freire, 2000; Freire and Magalhães, 2002; Viegas and Faria, 2004). The present abstention figures are in line with those in the central and southern European countries and lower than those in the Nordic countries.

Let us now look at the cases in which this difference is more marked, specifically in the forms included in "new forms of participation" and "protest participation".

Only $1.7 \%$ of the surveyed Portuguese use the internet for political purposes. This figure is substantially lower than that encountered in the other 


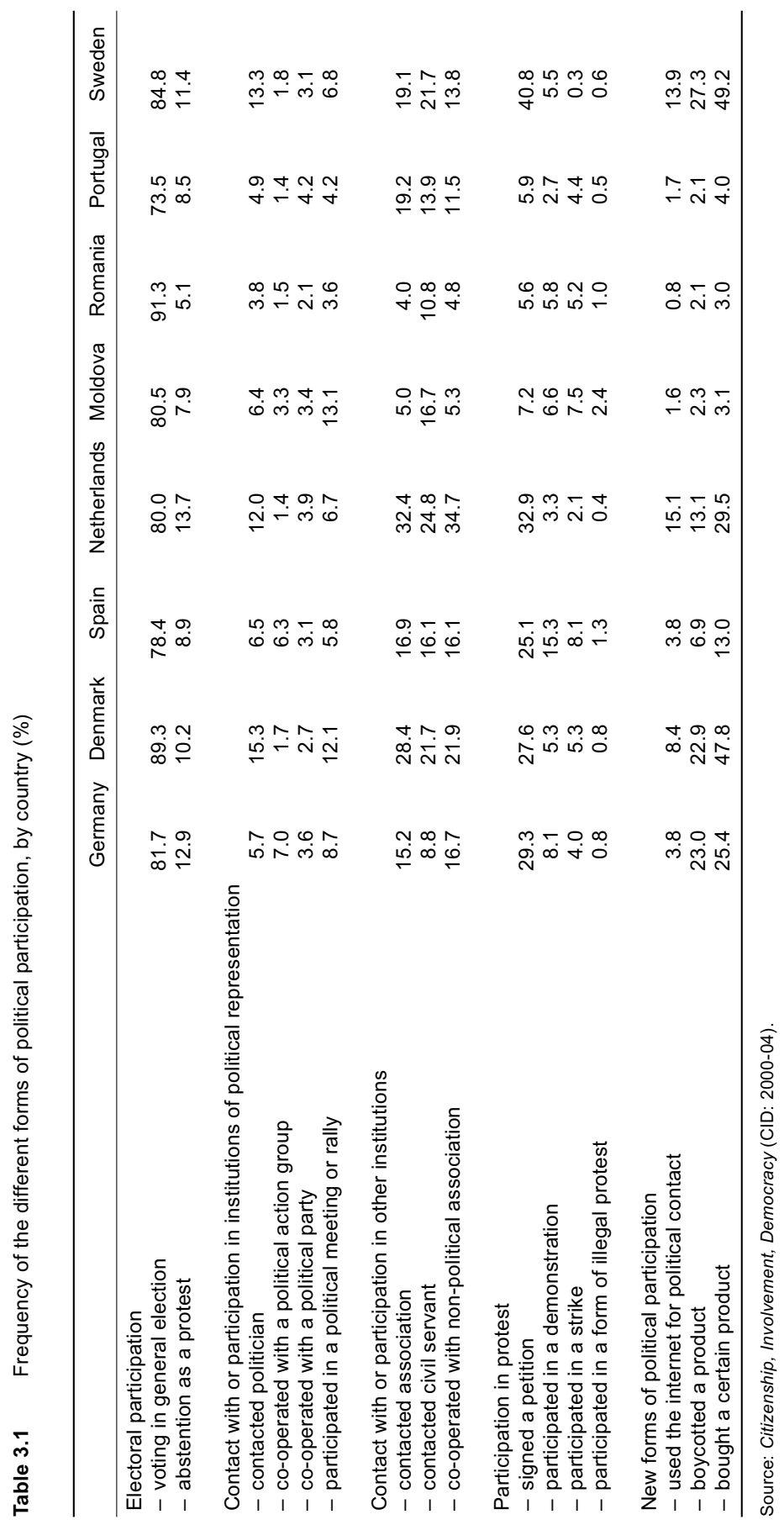


Western democracies, in particular Sweden (13.9\%), the Netherlands (15.1\%) and Denmark (8.4\%). Only the Eastern European countries register lower percentages of participation in this form.

The difference is even greater when the other indicators for this same group of forms of participation are considered. Only $2.1 \%$ of Portuguese respondents have boycotted a product for social, political or environmental reasons, a figure far lower than in Sweden (27.3\%), Germany (23\%), Denmark $(22.9 \%)$, or even Spain (6.9\%). The differences in Portugal in relation to the other European countries, with the exception of the Eastern European countries, are even more significant if the indicator "the purchase of certain products for social, environmental or political reasons" is taken into account. In Portugal only $4 \%$ of respondents answered this question positively, in comparison to $49.2 \%$ of the Swedes, $47.8 \%$ of the Danes, $29.5 \%$ of the Dutch, and $13 \%$ of the Spanish.

In the forms grouped together in "protest participation", the differences of Portugal in relation to the other countries are generally narrower than for the "new forms of participation", though still significant. The greatest difference lies in the indicator "sign petitions", for which only $5.9 \%$ of the Portuguese respondents answered positively, in comparison to $40.8 \%$ of the Swedes, $32.9 \%$ of the Dutch, $29.3 \%$ of the Germans and $25.1 \%$ of the Spanish. Only for Romania are lower values than those registered for Portugal to be found.

In the other forms of protest participation the differences are narrower. There is an exception, however, in that for "participation in demonstrations" and "participation in strikes" the values for Portugal are lower than those for the other countries, with occasional exceptions. This minor difference is due to the low rate of participation in these forms in the other countries, in particular with regard to participation in strikes. In this form of protest, it can be seen that the percentages for Sweden and the Netherlands are lower than those registered in Portugal.

With reference to institutional political participation, whether "electoral participation" or "participation in institutions of political representation", it can be seen that the discrepancies in percentage points between Portugal and the other countries are narrower. In the case of "working with political parties" it can be seen, indeed, that the percentage of participation in Portugal $(4.2 \%)$, though low, is higher than that in all the other countries (though these differences have little statistical significance).

For participation in other not strictly political institutions the percentages registered in Portugal are higher than for political institutions, though, generally speaking, they are lower than those registered in the other countries. Some of the forms bunched together in this group define participation that is in the public sphere but not strictly political. In the case of participation in or collaboration with associations, given the absence of information on the type of association in question, it is not known whether an association 
pursues strictly social ends (socialising activities, the strengthening of cultural or religious identities, charity work) or is directed towards debate in the public sphere. In the latter case, the political nature is more obvious, though it is precisely these associations that are least represented in Portugal, as was observed in another study (Viegas, 2004).

The separate analyses carried out above, by form of participation and country, allow political participation in Portugal, in comparison with other European countries, to be visualised better.

The forms bunched together in "new forms of participation" and, to a lesser degree, those included in "protest participation" are those in which the percentage for Portugal is less than that for the Western European countries. In the first case, the most obvious explanation implicates the factors that have been mentioned as lying at the base of the transformation in political culture: lower indices for education, a lower percentage of workers in the scientific and technical sector, less widespread adoption of new technologies, and a lower index of concentration in large conurbations. Undoubtedly, there have been great changes in these aspects in Portugal, but the differences in relation to the most advanced democracies are still large.

In the case of the forms of "protest participation", the differences between Portugal and the other countries are narrower, partly due to the fact that these forms of participation are also low there. We may be faced with a conjunctural situation that cuts across the different European countries. The results for Portugal, however, may also be a consequence of specific factors, in particular the heavy dependence of protest action on the political parties. This assertion will be picked up in the following point.

With reference to "participation in institutions of political representation", the difference in the values for Portugal in comparison with the other European countries is smaller, owing to the fact that these forms of participation also have a weak showing in those countries. It is worth registering the low participation in activities linked to political parties in both developed European countries and Portugal.

It is also worth noting that, in Portugal, "participation in other institutions", non-political institutions, has higher percentages when compared with other forms of participation. The gaps with the other countries are narrower, too.

\section{Types of political participation}

When political participation was analysed above, each of its forms was considered in isolation. These forms were, of course, organised in five blocks "electoral participation", "participation in institutions of political representation", "participation in other social institutions", "protest participation" and "new forms of political participation" -, though, fundamentally, for reasons of the ordering of the results. 
It should be said, however, that the arrangement of the forms of participation into groups was not completely random or intuitive. In fact, it took account of the most recent theoretical and empirical contributions to the problem. Even so, it is to be noted that we are not dealing with a typology of forms of political participation that is unequivocally accepted and beyond all discussion. Be that as it may, with a development phase behind them, the various typologies contain common areas.

For this reason, it is necessary to validate this typology in empirical terms. An attempt will be made to ascertain whether citizen involvement in a certain form of political participation produces a higher probability of involvement in the other forms that are included in the same type, than in the forms of the other types of participation. In statistical terms, it is of interest to ascertain whether there are clusters in the participation forms. Hence, a principal component factor analysis of the different forms of political participation was tested for a subset of the countries selected for this study: Portugal, Denmark, the Netherlands and Romania (table 3.2).

Broadly speaking, validation of the theoretically established typology requires that the results for each country satisfy three conditions, i.e. that: i) the number of factors resulting from the principal component factor analysis is four (relating to the four types of political participation established as the hypothesis, excluding electoral participation); ii) the most weighted variables in each factor correspond to the political participation forms of the participation type initially considered; and, finally, iii) the total explained variance is relevant, at least over $50 \%$.

Let us look at each of these conditions. In all the countries considered, with the exception of the Netherlands, the principal component factor analysis presents four factors, in accordance with the four types of participation initially proposed. In the Dutch case, the forms "illegal protest" and "co-operation with a political action group" are the most weighted variables of a new factor, which does not appear in the other countries. In these, those forms of participation are more strongly associated with other protest forms, defining a single factor. This is a specificity of the Netherlands, which, from these results, shows that this country has a movement of illegal protest that is dissociated from other protest forms and is closely related to action groups and not political parties.

The existence of four factors does not necessarily imply that the most weighted variables in each of them correspond to the forms of participation that we included in the same type of participation. It is, therefore, of interest to verify this.

Let us analyse what happens with the type of participation called "participation in institutions of political participation". Three of the forms of this type of political participation - "cooperation with a political party", "participation in a political meeting or rally" and "co-operation with a political 


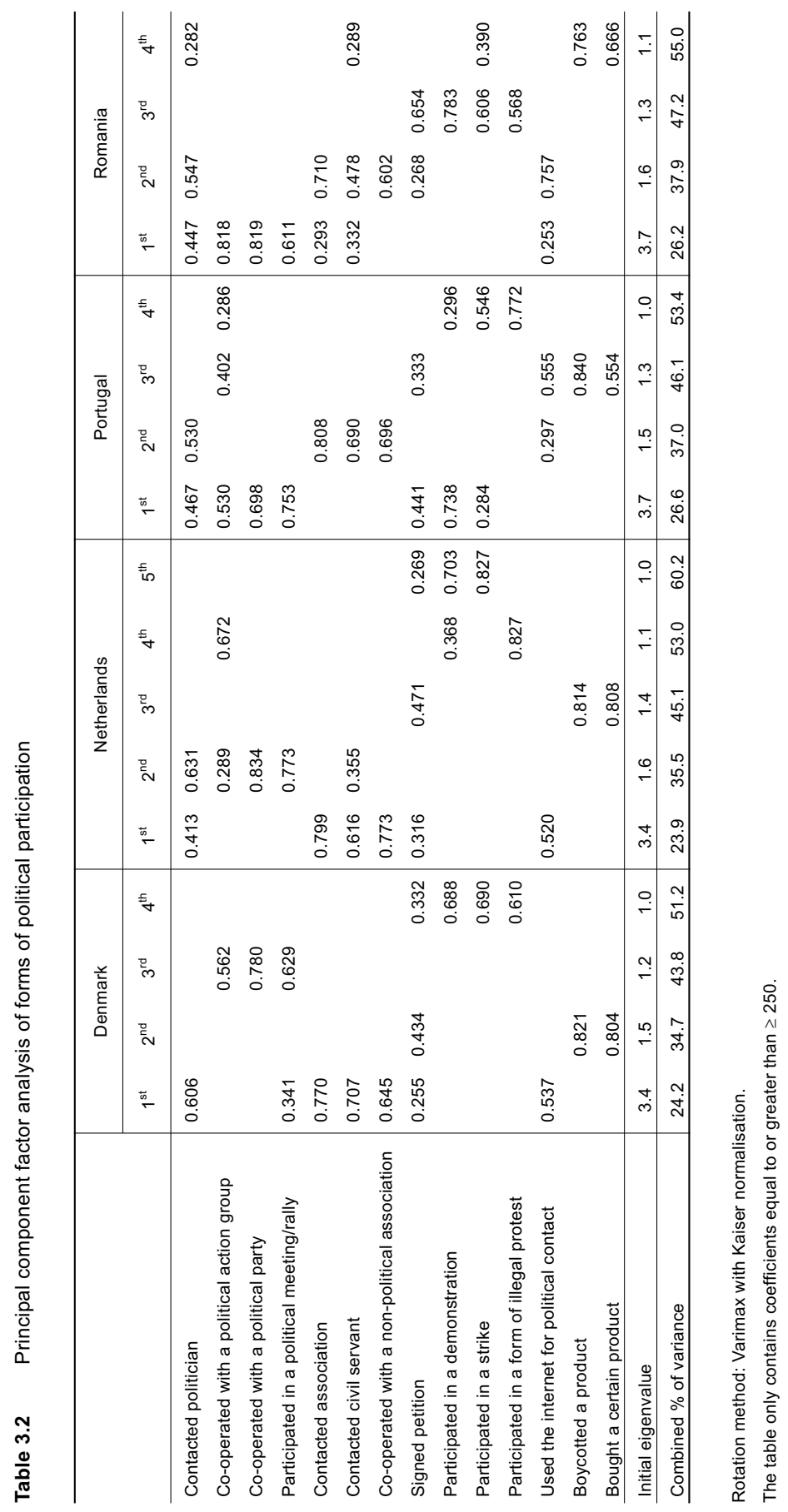


action group" define the most weighted variables of the same factor resulting from the principal component factor analysis, in all countries except the Netherlands, with regard to the last form dealt with, a case that has already been explained above. For the form relating to "contact with a politician to resolve a question", it is only in the case of Denmark that the corresponding variable is included, with a higher weighting, in the same type of political participation considered, i.e. "participation in institutions of political representation". In the other countries this form is included more firmly in the type of participation termed "participation in other institutions". It should be noted, however, that in Portugal and Romania the weighting of the variable corresponding to "contact with a politician", though not at the top, has high values (0.467 and 0.447 , respectively).

Despite the discrepancies mentioned, it may be said that the nuclear forms of participation that were initially integrated into the type "participation in institutions of political representation" are closer to each other than to the forms of the other types of participation. To a great extent, this validates the initial hypothesis that a type of political participation is being dealt with.

With reference to the type "participation in other institutions", it can be seen that the three forms that, hypothetically, make it up correspond to the most weighted variables of the same factor in all the countries. However, this same factor also includes, with strong weighting, the form "used the internet for political contact" in all the countries except Portugal - which departs from the initial hypothesis.

Despite this discrepancy, it was still considered that the type of participation termed "participation in other institutions" only includes the three forms mentioned above, which, in all the countries, define the most weighted variables of the same factor.

Let us now look at the type participation termed "protest participation". Three of the forms that initially make up this type of participation - "participation in demonstrations, "participation in strikes" and "participation in forms of illegal protest" - appear, with exceptions, in the same factor and with a high weighting. The first deviation in relation to the hypothesis corresponds to the last of the forms indicated, which, in the case of the Netherlands, as mentioned above, is recorded with greater weighting in a new factor. The second deviation corresponds to the form "sign petitions", which only in Romania is included with greater weighting in the type "protest participation".

Despite this deviation in relation to the initial hypothesis, it was decided to maintain the type "protest participation" as being included in the four forms initially proposed. In fact, in the principal component factor analysis, carried out for the various countries, the solid core of the forms of this participation type behaves as expected.

Finally, let us check the behaviour of the variables corresponding to the forms of participation initially included in the type "new forms of participation". 
Table 3.3

Index of the types of political participation

\begin{tabular}{lcccccccc}
\hline & Germany & Denmark & Spain & Netherlands & Moldova & Romania & Portugal & Sweden \\
\hline $\begin{array}{l}\text { Overall } \\
\text { participation }\end{array}$ & 0.11 & 0.16 & 0.10 & 0.16 & 0.06 & 0.04 & 0.06 & 0.16 \\
\hline $\begin{array}{l}\text { Participation in } \\
\text { political }\end{array}$ & 0.06 & 0.08 & 0.05 & 0.06 & 0.07 & 0.03 & 0.04 & 0.06 \\
institutions \\
$\begin{array}{l}\text { Participation in } \\
\text { other }\end{array}$ & 0.14 & 0.24 & 0.16 & 0.31 & 0.09 & 0.07 & 0.15 & 0.18 \\
institutions & 0.11 & 0.10 & 0.12 & 0.10 & 0.06 & 0.04 & 0.03 & 0.12 \\
$\begin{array}{l}\text { Protest } \\
\text { participation }\end{array}$ & 0.17 & 0.26 & 0.08 & 0.20 & 0.02 & 0.02 & 0.03 & 0.30 \\
$\begin{array}{l}\text { Participation } \\
\text { through new } \\
\text { forms }\end{array}$ & & & & & & & & \\
\hline
\end{tabular}

Scale from 0 to 1

Source: Citizenship, Involvement, Democracy (CID: 2000-04).

Two of them - "boycott a product" and "buy a certain product" for social, political or environmental reasons - correspond to the most weighted variables of the same factor, which is consistent with the hypothesis. In the case of the form "internet use", only in Portugal does this variable behave in accordance with what was initially expected. However, in theoretical terms, this form of participation clearly belongs to the type "new forms of participation". The explanation for the fact that this form of participation is more associated with the forms of the type "participation in other institutions" may be that the respondents did not take into consideration that this use related to political matters. For this reason, it was decided to consider this type of participation with the advanced forms in the initial hypothesis.

With regard to the third criterion established, it is to be seen that the total explained variance in any of the principal component factor analyses carried out is always above $50 \%$.

That said, if we consider the analyses carried out, it is legitimate to construct participation indices for the four types of political participation considered. Each of these indices is constructed on the basis of the forms that were initially established for each type of political participation, with equal weighting. The comparative results, presented on a scale from 0 to 1 , are shown in table 3.3.

Table 3.3 complements the information in the point above, in which participation was analysed by form, though the values now correspond to the aggregation of the forms of participation, in accordance with the types considered.

The overall index of participation for Portugal (0.06) is seen to be the second lowest in the group of countries considered, i.e. equal to Moldova and only higher than Romania. 
In the type "participation in political institutions", Romania alone registers lower values than Portugal, with Spain just a hundredth above. It should be noted, however, that almost all the other values are very close to each other.

In the type "participation in other institutions", the index for Portugal is 0.15, which places it decidedly above Romania (0.07) and Moldova (0.09), very close to Spain (0.16) and slightly above Germany (0.14). Even in relation to the countries where the overall index of participation is greater, such as Sweden, the differences are small. For Portugal, this relative position is only to be seen in this type of participation. But, as mentioned above, this type of participation relates, to a great extent, to a pre-political field. In the absence of information on the type of association with which the respondent said he or she co-operated, it may be said that this involvement very probably took place in recreational or charitable institutions, especially with responsibilities for social integration.

The Portuguese figure for the index "protest participation" $(0.03)$ is the lowest of all and, in this case, the differences between countries are not negligible: 0.12 for Denmark and Sweden, 0.11 for Germany and the same for Spain. As noted earlier, it may be that conjunctural values are at play, in particular in Portugal.

In the type "new forms of participation", the aggregate values confirm what has already been seen in the detailed analysis of the forms that are included in this type of participation. Portugal (0.03), Moldova (0.02) and Romania (0.02) present very low values in the index in comparison to countries like Sweden (0.30) or Denmark (0.26). Though the figure for Spain (0.08) is low in the group of countries, it is still somewhat higher than that of Portugal.

By itself, the data analysed does not allow us to make a judgment on the development of political behaviours and political culture. Even so, there are differences between countries with different levels of social and economic development that it is of interest to analyse. With this analysis, certain clues will probably be found that allow us to produce certain considerations on the trends in the phenomenon of political participation.

\section{Conclusions}

In the first place, it was ascertained that political participation registers relatively low values in Portugal, in many cases only above the values encountered in the Eastern European countries selected. This overall view, however, corresponds to an average value for participation, which covers the spectrum from electoral participation to "new forms of participation", and does not give an account of the specific differences in Portuguese participation in relation to the other European countries, which are revealed when the analysis concentrates on each of the forms of participation. 
What are we referring to? To certain differences in participation values, as well as to the relationships and associations between different forms of participation. Let us recall some of those differences.

The forms of participation that register the greatest discrepancy in values between Portugal and most of the European countries, excluding those in the east, are included in the type "new forms of participation": internet use and the boycott of products or purchase of particular products for political or social reasons. The reason for these values seemed clear: technologically more developed countries, with higher indices of education and more established democratic traditions recorded higher percentages of involvement in these forms of participation.

Similarly, in certain forms of "protest participation", especially involvement in demonstrations and, more markedly, the signing of petitions, the participation rate in Portugal was lower than in the other European countries, except for those in the east. Any interpretation of these results should take account of the fact that the Portuguese rates of participation in the other forms included in this type of political participation, i.e. demonstrations and strikes, are not very different from those in the other European countries.

An aggregate reading of these values indicates that we are not facing greater radicalisation in Portuguese society or a political and social situation with higher levels of conflict. The reasons for the differences in political participation in Portugal in relation to the older European democracies, as far as the signing of petitions and, to a lesser degree, participation in demonstrations is concerned, is a question of differences in political culture.

In connection with the forms of protest participation, it is also of interest to mention a particularity in the case of Portugal. In this country, these forms of political participation are strongly associated with party involvement, in contrast to what we see in the other countries, in which these actions are somewhat independent of the parties.

Finally, another peculiarity of political participation in Portugal should be stressed. Involvement in not strictly political associations registers quite high values in Portugal, in particular in the item "contact with associations", which are only exceeded in the Netherlands and Denmark. As has already been said, this figure shows that participation in Portugal has fewer implications for the broadening of the debate in the public and political sphere than in the developed European countries, though, on the other hand, it has a strong dimension of social and political integration.

\section{References}

Barnes, S. H., M. Kaase, et al. (1979), Political Action. Mass Participation in Five Western Democracies, Beverly Hills, California, Sage. 
Bobbio, Norberto (1984, 1988), O Futuro da Democracia, Lisbon, Publicações Dom Quixote.

Bourdieu, Pierre (1984), “La délégation et le fétichisme politique”, Actes de la Recherche en Science Sociales, 52-53.

Corcoran, Paul E. (1983), "The limits of democratic theory”, in Graeme Duncan (ed.), Democratic Theory and Practice, Cambridge, Cambridge University Press.

Diamond, Larry, and Marc F. Plattner (eds.) (1996), The global resurgence of democracy, Baltimore, The Johns Hopkins University Press.

Freire, André (2000), “Participação e abstenção em Portugal: análise das eleições legislativas, 1975-1995", in José Manuel Leite Viegas and Eduardo Costa Dias (eds.), Cidadania, Integração, Globalização, Oeiras, Portugal, Celta Editora.

Freire, André, and Pedro Magalhães (2002) A Abstenção Eleitoral em Portugal, Lisbon, ICS.

Habermas, Jurgen (1976, 1988), Legitimation Crisis, Cambridge, Polity Press.

Held, David (1987), Models of democracy, Cambridge, Polity Press.

Huntington, Samuel, Crozier, Michel, and Watanuki, Jóji (1975), The Crisis of Democracy. Report on the Governability of Democracies to the Trilateral Commission, New York, New York University Press.

Inglehart, Ronald (1997), Modernization and Postmodernization. Cultural, Economic, and Political Change in 43 Societies, Princeton, Princeton University Press.

Norris, Pippa (ed.) (1999), Critical Citizens. Global Support for Democratic Government, Oxford, Oxford University Press.

Przeworski, Adam (1988), "Democracy as a contingent outcome of conflicts", in Jon Elster and Rune Slagstad (eds.), Constitutionalism and Democracy, Cambridge, Cambridge University Press.

Schmitter, Philippe, and Terry Lynn Karl (1996), "What democracy is... and is not”, in Larry Diamond and Marc F. Plattner (eds.), The Global Resurgence of Democracy, Baltimore, The Johns Hopkins University Press.

Schmitter, Phillipe C. (1996), "Dangers and dilemmas of democracy", in Larry Diamond and Marc F. Plattner (eds.), The Global Resurgence of Democracy, Baltimore, The Johns Hopkins University Press.

Verba, Sidney, and Norman Nie (1972), Participation in America, New York, Harper \& Row.

Viegas, José Manuel Leite (2004), “Implicações democráticas das associações voluntárias: o caso português numa perspectiva comparativa europeia", Sociologia, Problemas e Práticas, 46, pp. 33-50.

Viegas, José Manuel Leite, and Sérgio Faria (2004), “A abstenção nas eleições legislativas de 2002", in André Freire, Marina Costa Lobo and Pedro Magalhães (eds.), Portugal a Votos, vol I, Lisbon, Imprensa de Ciências Sociais. 

Part II INSTITUTIONS

AND PUBLIC POLICIES 



\title{
Social development policies Employment and social security
}

\author{
Luís Capucha, Elsa Pegado and Sandra Palma Saleiro
}

Besides being extremely extensive, the field of social policies has relatively fluid frontiers. With a definition that is not based on conceptual premises but rather on the institutional design of the administrative apparatus, the field can include areas such as housing, health, labour and "the social dialogue", civil dialogue, the family, education, employment and occupational training, social security, social action, community development, equal opportunities for women and men, and the fight against poverty and social exclusion. Of this group, we devote the present chapter to two of the central areas of social policy, namely employment and social security as strategic instruments of social development. ${ }^{1}$

These areas will be analysed from a diachronic perspective, with the last decade representing the main time span, though the analysis reaches back to the process set in motion by the revolution of 25 April 1974. From that date until November 1975 the "revolutionary foundation" of the embryonic welfare state took place. Between 1976 and 1986, the Portuguese welfare state passed through a second period, characterised by the introduction of reforms that were meant to prepare it for membership of the European Economic Community. The period that followed was one of expansion, lasting until the middle of the 1990s, when a fourth period began. This was marked by a transition to active social policies representing the dynamics of a recalibration of the European social model and the activation of social policies. The last period corresponds to the most recent years,

1 Social development, a comprehensive concept that includes a variety of domains connected with the quality of life and the environment in an extended perspective of time and space, cannot result from these two policy areas alone; on the contrary, it requires integrated, concentrated and multi-dimensional intervention. The selection made here does not, therefore, have any other criterion than that of the general economy of the publication. 
marked by policy reforms of a more neo-liberal nature. The text concludes with an overall assessment of the challenges facing social development policies in Portugal, on the basis of a systematisation of the main weaknesses in this area.

\section{The revolutionary period after 25 April 1974}

The break that occurred in Portuguese society on 25 April 1974 was deep and all-embracing. One of the main driving forces behind this change was the widely shared goal of putting an end to decades of underdevelopment, with consequences that were reflected, for example, in poverty rates that included more than $43 \%$ of the population (Silva, 1984) ${ }^{2}$ or in the inexistence of social protection or health systems covering most of the population. ${ }^{3}$ There was no unemployment per $\mathrm{se}^{4}$ but, with the underdeveloped economy (particularly evident in the rural areas), with the concentration of industry in small areas, with investment in medium to large size units typical of the "second wave" (which, in our case, was late, given that the restriction on industry continued until the 1960s), and with services being severely limited in importance and for the most part traditional in nature, poverty was a normal experience for the greater part of the population. The haemorrhage of immigration is a reflex of this situation.

Among other characteristics, the revolutionary period had the merit of establishing a system of rights and legal measures, enshrined in the Constitution of 1976. These form the foundations of the legal structure of the welfare state in Portugal, though without the economic and financial support that would allow expectations to be met and some of the measures created to be carried out.

Along with the reestablishment of political liberties, the freedom of association, the freedom to organise and engage in trade union activity, and the institutionalisation of the social dialogue (in spite of the prevailing labour conflict in

2 The value is based upon a calculation incorporating the National Survey of Family Expenditure for $1973 / 4$. The poverty line was $75 \%$ of the average equivalent adult income. Other lower limits were tried but all of them placed absolute poverty above relative poverty, which indicates the seriousness of the general need among the population.

The beneficiaries of the welfare bodies, the main pillars of the system, did not number more than 862,700 and 833,500 families in 1959 (in 1970 not more than $60 \%$ of the population was covered by some scheme, even if it was minimal). More than $30 \%$ of the workers in the diverse sectors were unprotected and the revenues from social protection did not exceed $3.2 \%$ of the GNP. Only $14.9 \%$ of expenditure was on pensions $(17.8 \%$ in 1970 , there being only 187,300 pensioners). Only in 1960 and 1961 were minimum old-age and disability pensions introduced. The risks of unemployment and occupational accidents were practically not covered at all.

4 Although, as in the whole of Europe, women participated in the labor market on a limited scale, with the rate of female employment being only $13.1 \%$ in 1960. 
practice), the national minimum wage was introduced, minimum pensions doubled in value and ceilings were introduced for higher pensions. At the same time, pension funds became accessible to rural workers; a non-contributory system was established, including the social pension, which made welfare cover universal; and measures such as unemployment benefit, medical assistance, subsidised medicines and child welfare were made available to all members of tax payers' families. The first minimally effective medical and social services were created. In 1975, the various regimes already covered, as active participants, $78 \%$ of the active population and the number of pensioners rose to 861,700 $(187,300$ in 1970).

Public spending on social security grew substantially, to $8.7 \%$ of GNP in 1975 , and the expenditure on pensions grew to $45 \%$ of the total. At the same time, the period of economic instability caused unemployment and increased expenditure on unemployment benefits.

\section{Stabilisation: 1976-1986}

With the abatement of the intense social participation and agitation and of the relative political instability and economic disorganisation that followed the April Revolution, the country came to be governed by an alliance between the Socialist and the Christian Democratic parties, which leant towards the European Community. Between 1976 and 1986, Portugal experienced a period of austerity and macro-economic stabilisation (associated with IMF and World Bank intervention), which was marked by heavy restrictions and severe setbacks in the previous dynamics of improving families' lives. There was an accentuated drop in the purchasing power of salaries and pensions. Poverty remained at high levels, reaching a figure of 35\% in 1980 (Costa et al., 1985) ${ }^{5}$ and unemployment rose to levels to which Portuguese society was not accustomed.

However, this austerity did not prevent a series of changes directed at the "Europeanisation" 6 of the country. The application for EEC membership implied the adoption of a series of legislative instruments and institutional developments that were indispensable to any move towards the acquis communautaire. The Social Security Financial Management Institute (Instituto de Gestão Financeira da Segurança Social), the District Centres of the Social Security (Centros Distritais de Segurança Social), the National Health System (Sistema Nacional de Saúde) and the Employment and Occupational Training Institute (Instituto de Emprego e Formação Profissional, IEFP) were created at this

5 The poverty line conforms to the same criteria as that mentioned in the note above.

6 An expression that refers to a kind of choice of institutions and practices, taken to be common in Europe, as a reference for action and for an evaluation of the changes in less developed countries, such as Portugal. 
time. Certain welfare measures were launched, including the extension of parental leave to 90 days; the creation of a welfare system for self-employed workers (providing for sickness, medical assistance, subsidised medicines, maternity benefit, the death grant, and invalidity and old age pensions); the inclusion of domestic workers in the general welfare system; and the raising of the contributory rates paid by workers and employers into the system.

One of the most important changes, from the viewpoint of its structural impact, was the passing of the Social Security (Bases) Act in 1984. The law established the organisation of the system around three basic components: the Contributory System, the Non-contributory System and Social Action. The first was (and is) compulsory and included various sub-systems - some later integrated into the general system - which covered the situations typically included in social security systems in Europe, e.g. sickness, maternity, occupational accidents, disability, old age, death and family protection. The Non-contributory System covered families, the disabled and the elderly not covered by the Contributory System, providing benefits such as child allowance, maternity benefit, surviving dependents' pensions, disability pensions and social pensions. Finally, Social Action included the provision of small amounts of financial support, depending on the budgetary allowances to deal with occasional situations of serious social risk, and the regulation and financing of social facilities for the disabled, children, the elderly and the community, among others.

At this time, in their turn, the main socio-occupational training programmes and measures for the disabled were launched, along with the main structured and systematic initiatives for ongoing occupational training for the unemployed. In a context of severe economic depression and containment, in which the situation persisted of creating policies and institutions without the availability of the corresponding funds (a situation already seen in the revolutionary period), the performance of the systems remained extremely poor, with the feebleness of the policies of inclusion and social solidarity being particularly well-known. In this way discrepancies emerged between established rights and actual access to them by most of the population.

\section{Extension and growth: 1986-1994}

After Portugal joined the European Economic Community, a period of growth in the coverage and levels of social and employment policies began. In a favourable international economic situation and a stable political climate, Community funds allowed the implementation of programmes and measures designed during the previous period. This was particularly so in the area of employment and training - from ongoing in-company training to the training of the unemployed and dissemination of the responses and institutions of the socio-occupational rehabilitation system for the disabled (Capucha et al., 2004). 
In spite of the prevalence of the idea of expanding existing measures, the first initiatives to train disadvantaged groups were also launched.

Regarding the Social Security, the main direction of the period's priorities was also towards the expansion and growth of existing measures, of which the creation of the fourteenth month for pensions and the creation of a network of facilities and services are examples. This network was often managed in partnership with the social partners and NGOs.

Thus, while in 1980 social expenditure did not rise above $12.8 \%$ of GNP (while in Europe it was 24.3\%), with a rise to 15\% in 1990, a new leap to $23 \%$ occurred in 1997. The intensity of this effort, in comparison with the European average, is also clearly reflected in this increase. In 1980, the social expenditure per capita in Portugal was only $31.4 \%$ of that of Europe, rising to $38 \%$ in $1986,47.6 \%$ in $1990,51.6 \%$ in $1995,59.3 \%$ in 2000 and $63.7 \%$ in $2002(\mathrm{Eu}-$ ropean Commission, 2005).

It was during this period that the first stable anti-poverty policy was initiated. In 1987, the II European Anti-Poverty Programme was extended to our country, in the form of 10 research/action projects on a relatively small scale and with various themes. Together with the Community-financed projects, the government financed another ten national projects. Later, in 1993, the III European Anti-poverty Programme financed four larger projects in Portugal, on the basis of principles such as partnership, local development and the participation of local populations. These principles were transposed to a National Anti-poverty Programme (PLCP, Programa National de Luta Contra a Pobreza) which, until the present - in 2005, the last wave of these projects is still active - has represented an important instrument for intervention within Portugal. This intervention has boosted other measures, such as the Special Rehousing Programme, involving multi-dimensional projects lasting four years on average. It is active in areas such as the creation of social amenities, special occupational training, education, social or handicraft employment initiatives, the boosting of declining productive activities, housing reconstruction, and cultural animation. Between 1996 and 2001, 339 projects were financed throughout the country with $€ 84,134,295$ (Organização Internacional do Trabalho [International Labour Organization], 2003). ${ }^{7}$ During this period, similar or comparable projects were also promoted first by the I Community Horizon Initiative and later, in an expanded form, by the operational sub-programme Integrar ("Integrate"). The latter expanded Community stimuli and the usual social action of PLCP projects with a great number of initiatives related to the Social Labour Market (Mercado Social de Emprego) and special training.

$7 \quad$ One of the greatest weaknesses of the programme is the dispersion and limited dimension of each project (an average of $€ 248,184$, which results in averages of only $€ 62,045$ per year/project, insufficient to attack the problems at their foundations in the areas where they are found). 


\section{The new generation of active social policies: 1995-2001}

The political cycle of 1986-1996 covered two different economic periods, and that situation had important implications for social policies. While until 1990 the average economic growth rate was higher than $5 \%$ per year, with the Gross Fixed Capital Formation (GFCF) growing more than 10\%, between 1990 and 1994 the average growth decreased to $2.1 \%$, with even negative growth in 1993, after a fall of three percentage points between 1990 and 1991.

In 1995, some of the worse effects of the economic crises of the early 1990s and the neo-liberal responses adopted to deal with them were reaching a "peak". The economic situation once again reflected a period of relative efficiency, with the GNP growing 3.5\% per year on average between 1995 and 2000 . The GFCF, however, now contributed less $(6.8 \%)$, with growth largely being fed by an increase in employment. The productivity (GNP mp/population employed) also grew, at a pace of 3.4\% per year between 1986 and 1990, 1.2\% between 1991 and 1994 and 2.0\% between 1995 and 2000. In this year, productivity was around $62.5 \%$ of the European average (INE, Contas Nacionais Anuais [nnual National Acconts])).

Poverty had begun to grow again and unemployment reached higher levels, with the quality of employment and the capacity for business innovation remaining very low. Within this context, the Socialist Party won the election with a programme that asserted the priority that would have to be given to education policy and used the fight against poverty as its banner. During this period, a new generation of active social policies was launched, a notion that was emerging throughout Europe as an alternative to neo-liberal proposals. The goal was to combine reform of the welfare state of the Fordist period with maintenance of the high social patterns typical of the European social model.

The indicators for employment and unemployment improved markedly during the period. Between 1995 and 2000, 337,000 jobs were created, with a reduction in the numbers of "false self-employed workers" and an increase from 3,040,200 pay-roll workers to 3,419,400. The rate of those economically active grew during the same period from $67.2 \%$ to $71.5 \%(63.6 \%$ for women), clearly above the European average (DEPP/MTS, Plano Nacional de Emprego 2001 [National Employment Plan 2001]).

The employment rate grew from $65.3 \%$ in 1995 (56.9\% for women and $74.3 \%$ for men; $35.6 \%$ for young men and $32.2 \%$ for young women aged between 15 and 24 ) to $68.3 \%$ in $2000^{8}$ (60.5\% for women and $42.0 \%$ for young people). In contrast, unemployment fell from $7.2 \%$ in 1995 and $7.3 \%$ in 1996 (with the figure for women being $8.0 \%$ and for young people $16.1 \%$, in the first of those two years), to $3.9 \%$ in 2000 (4.9\% for women and $8.6 \%$ for young people). Finally, long-term unemployment reached a rate of $2.8 \%$ in 1995, going down to around 1.5\% in 2000 (Eurostat, Labour Force Survey). 
However, a series of structural problems persists: we shall analyse them in detail later, only mentioning them here. In simple terms, they relate to a structural deficit in qualifications on the part of all age groups of the population - registered in spite of a rate of progress among the young people that is slower than that of our European partners; imbalances in the sectoral structure and fragility in the factors of competitiveness in a significant segment of the economy, which has low productivity, obsolete forms of organising work and a resistance to innovation, to improvement in the quality of employment and to the consequent rise in pay levels; and finally, the persistence of high levels of poverty and exclusion.

This was a situation in which, with the support of community funds, investment in businesses was merely technological (i.e. without interfering with productivity factors, in particular qualifications and the organisation of labour) or related to occupational training, whose effectiveness is still to be determined. There was real economic growth, as well as growth in the well being of families, which in a way hid the persistence of structural problems. In this scenario, the launch of the European Employment Strategy at the Luxembourg Summit in 1997 implied a more or less accentuated revision of the country's strategy and political priorities in terms of employment.

Of the four pillars defined in the European strategy (employability, entrepreneurship, worker and company adaptability, and equal opportunities for men and women) the priorities adopted favoured employability. This included the three-fold objective of (i) preventing unemployment, (ii) preventing long-term unemployment and (iii) promoting the inclusion of excluded groups. The prevention of unemployment covered a set of measures that were combined with those of the pillar of adaptability and sought an immediate rise in qualifications among the young people and the employed population alike, through a comprehensive strategy of lifelong learning. This included the creation of pre-school facilities, diversification of the educational and occupational training routes on offer to provide young people with a more qualified transition to active life, the provision of occupational training for the unemployed and ongoing training, and, in addition, the creation of Centres for the Recognition, Validation and Certification of Skills (CRVCS - Centros de Reconhecimento, Validação e Certificação de Competências) and knowledge acquired throughout life, which were closely linked with adult education and training courses, among other measures with extremely uneven impact

8 The calculation formula for the employment rate was altered in 1999, under the European Employment Strategy. While the numerator had previously included all employed people and the denominator the population between 15 and 64 years of age, from that year the numerator was also limited to the same age groups as the denominator, which for Portugal, with a significant participation of the older population in employment, represented a decrease in the indicator of almost two percentage points. 
and success. ${ }^{9}$ The promotion of preparatory action for sectoral conversion in sectors at risk of a competitive shock likewise represented a measure to prevent unemployment, though it was not carried out in any extensive manner.

In the area of long-term unemployment prevention, the initiatives Inserjovem (Youth Integration) and Reage (React) stand out. They were put into practice by the Employment Centres of the Employment and Occupational Training Institute (IEFP, Instituto de Emprego e Formação Profissional) to respond to the European goal of providing a solution - of employment or, preferably, guidance towards training - for all young people and adults before they completed, respectively, six and twelve months' unemployment. Based upon an innovative method of a multi-dimensional response, personally translated into an individual employment plan and negotiated with the unemployed, these measures were considered to be good practice at a European level.

Finally, with regard to the re-integration of excluded groups, of particular note are the diversification in the measures for the social labour market, the continuous increase in the people covered, and the expansion in the network of organisations capable of providing special training solutions. The link between the unemployment services and social action services responsible for the Guaranteed Minimum Income is another case of the action at this time that is worthy of note.

The expansion of social support services and facilities for the family and increases in support for employment and training where women were involved were the predominant features of the pillar of equal opportunities. If the second of these approaches reinforced the principle that gender equality cuts across all employment policies, the first appears particularly significant. In a society with high levels of female employment, as in Portugal, the lack of family support facilities, indispensable to the reconciliation of work and family life, could not but be felt as a problematic area. Even so, the period from

9 For example, on the positive side, the number of young people in the apprentice system is noteworthy, rising from 16, 792 in 1998 to 26, 078 in 2000; the number of unemployed people who received training grew in the same period from 9,724 to 14,478; the number of employed adults in training doubled between 1995 and 2000 (from 121, 487 to 310,863). In 2001, 28 Centres for the Recognition, Validation and Certification of Skills were operating, a number that rose to 56 in 2003. The number of adults registered rose, in the same period, from 7,019 to 28,636 (with the total, including 2002, being 60,130), adults in the process of recognition increased from 2,952 to 19,404 (with a total of 35,840 ), adults with validated skills increased from 496 to 8,300 (with a total of 12,476), those with certified knowledge went up from 467 to 7,734 (with a total of 11,488) and adults attending complementary training programmes increased from 130 in 2001 to 9 , 020 in 2003, totalling 13,958 in the three-year period (Ministry of Education, Directorate General for Vocational Training, December 2003). On the negative side, the persistence of early school-leaving is to be noted, as is the difficulty of opening businesses to ongoing training. 
1995-2000 was an exception in this area, for besides the creation of pre-school education, the rhythm of the creation of new facilities every year, which had been growing since 1986, went from 571 in 1995 to 721 in 2000 . At the same time, state investment in the creation of these facilities increased from 34 to 47.4 million euros between those two years and support for their operation increased from 380.1 to 763.6 million euros per year (DEPP/MTS, Carta Social 2002 [Portuguese Social Charter]).

In the pillar of adaptability, along with the goal of modifying the picture of qualifications in our country, initiatives to overcome certain blockages in the social dialogue plan are to be noted. The aim is to modernise employment - in the sense of combining greater flexibility and adaptation to change with greater security - and increase the capacity for innovation. Besides the general strategic agreements and the joint declaration that supported the launch of the National Labour Plan, we may note the signing of three agreements of moderate reach, in the areas of i) employment, education and training, ii) health and safety at work, and iii) the sustainability of the pension system, containing, for the first time, concrete objectives in areas of strategic importance for the country.

In the field of employability, with priority for the creation of self-employment not being applicable to Portugal (which is already in excess in comparison with European patterns), ${ }^{10}$ special attention was paid to the fight against false self-employment and the simplification of the bureaucracy to set up a company, through the Enterprise Formality Centres (Centros de Formalidades para Empresas). One area in which there was very little progress was that of the development of the business function, perhaps the domain with the greatest vulnerability in the Portuguese employment system.

As the whole, these measures allowed the country to take advantage of the favourable economic situation and also made their own contribution to the creation of employment, independently of the dynamics of the economy. An econometric study evaluating the National Labour Plan showed that the net contribution of the policies may have been equivalent to nearly 50,000 jobs and that this contribution was particularly important when the economic indicators began to wane (Carneiro, 2003).

Besides being a pillar of the organisation of the state and society, guaranteeing social solidarity among the generations, access to resources and the confidence of the people in the political foundations of the governmental system, the social security system is a fundamental instrument in the redistribution of resources. This redistribution is not only vertical, through the transfer of resources from active to older generations, but also horizontal, allowing 


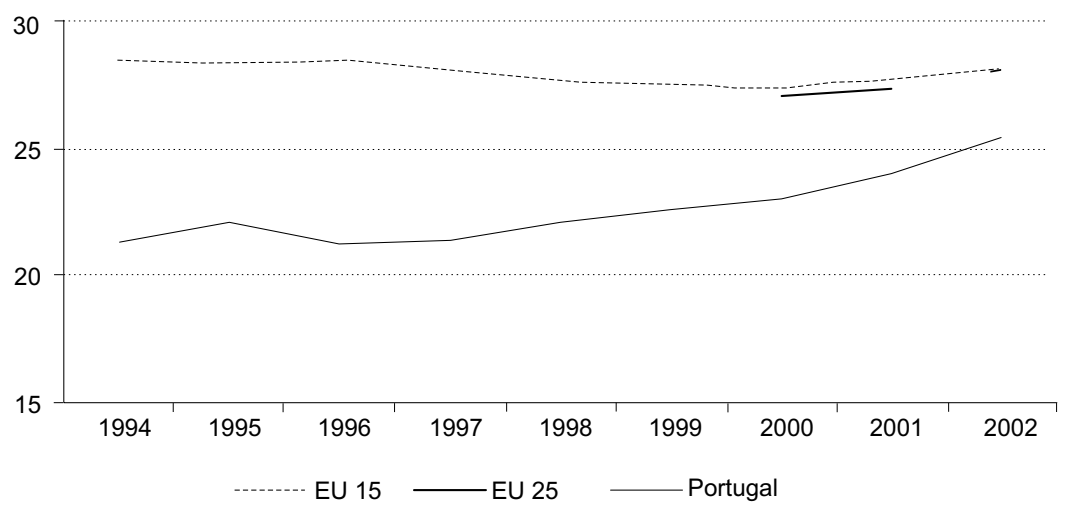

Figure 4.1 Total social protection expenditure (\% GDP), 1994-2002

Source: European Social Statistics Protection, Expenditure and Receipts, Data: 1994-2002, European Commission, Eurostat.

poorer beneficiaries to receive a fair deal, in particular through a "political" rise in the values of the lowest pensions. ${ }^{11}$ If there was a positive development in employment in the period from 1995-2000, the same occurred with the main performance indicators for the social protection system.

Thus, total expenditure on social protection rose from $22.1 \%$ of GDP in 1995 to $23 \%$ in 2000 and $25.4 \%$ in 2002 , which represents a notable effort to close the gap with the European average, as can be seen in figure 4.1.

With these values, Portugal has one of the bottom positions in the European table. Even considering the current 25 EU members, only Hungary and Slovakia are lower, as can be seen in figure 4.2. On the other hand, we are near countries like Spain - in relation to which we have had a faster progression (Guillén and Silva, 2001) -, Ireland and Greece and a group of new member countries such as Slovakia, Hungary and Slovenia.

The intensity of the social welfare effort is not measured through the proportion of total social expenditure in the GDP, but through the social expenditure per capita. In Portugal, development has also been positive in this respect. In 1980 , the proportion of social expenditure per capita in relation to countries in the current European Union, on the basis of purchasing power parity, was only $31.2 \%$. This proportion was maintained at $31.4 \%$ in 1986 , later rising to $38.0 \%$ in 1990 and $48.2 \%$ in 1995 . The value in 2000 was already $59.3 \%$ and rose to $63.7 \%$ in 2002. In that year, the value in euros was 4,298 per year in Portugal and 6, 748 in

11 The "efficiency" of social transfers as a whole in reducing poverty is $61.5 \%$ for the EU15 and $49.5 \%$ in Portugal, whereas the efficiency of "other transfers" beside pensions was $37.0 \%$ for Europe and 16.7\% for Portugal in 2001 (Ferreira, forthcoming). 


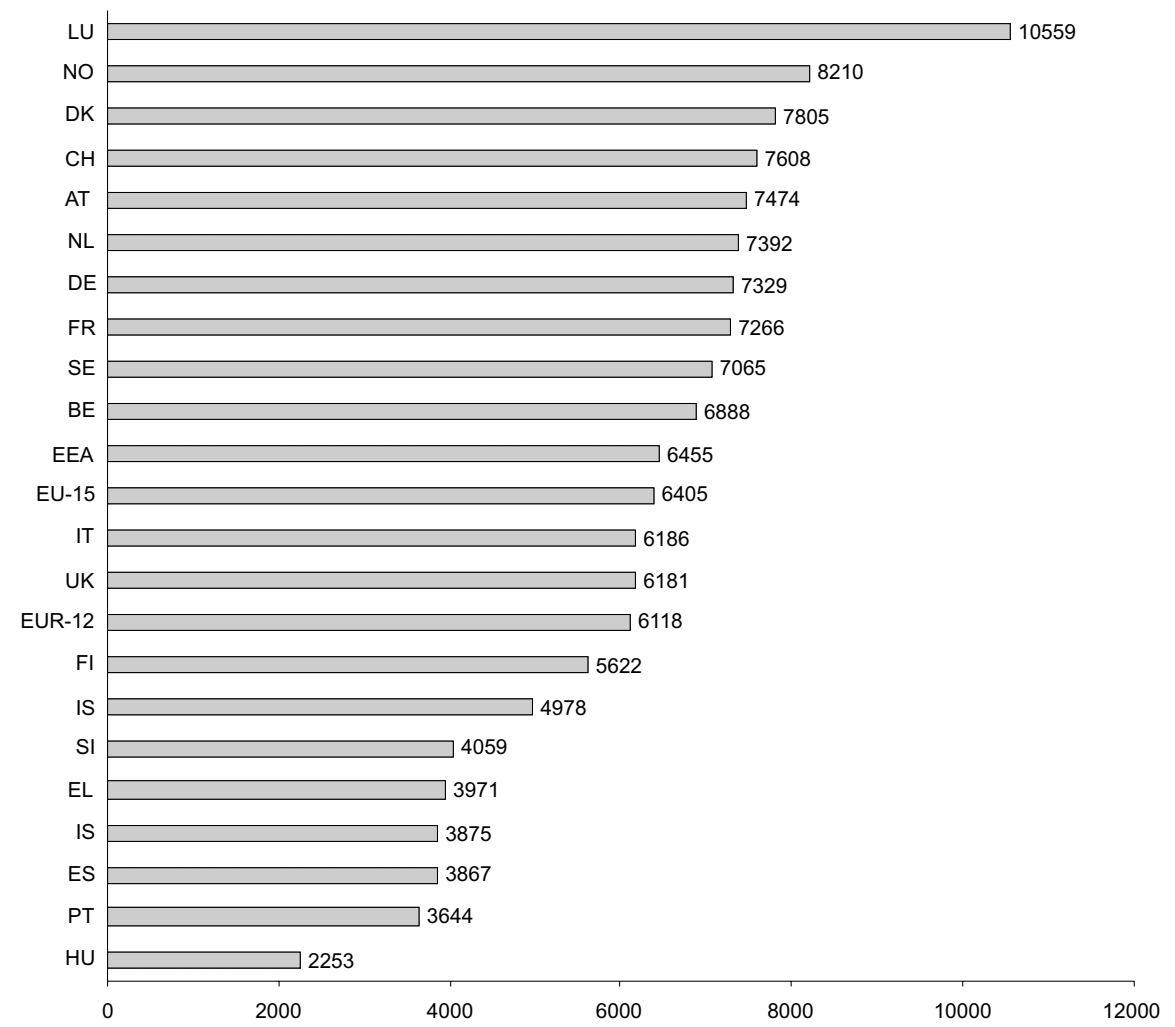

Figure 4.2 Expenditure on social protection in PPS per capita, 2001

Source: Statistics on Focus, Population and Living Conditions, Social Protection, 2004.

the EU15. Figure 4.3 seeks to illustrate how this gap has been closing. The progression has been notable, even if the difference is still excessive.

As figure 4.4 shows, the distribution of expenditure among the different functions registers a structure for Portugal that is close to that of other European countries with respect to old-age and surviving dependents' pensions ( $46.0 \%$ and $45.8 \%$ respectively in the EU and Portugal), and registers a larger proportion for illness and health care $(28.2 \%$ and $31.3 \%)$ and disability pensions $(8.0 \%$ and $12.3 \%)$. At the same time, Portugal understandably spends less than its partners on unemployment benefit ( $6.2 \%$ and $3.6 \%)$ and, surprisingly, given the rate of child poverty, the lack of family support facilities and the fact we are the country with the greatest levels of inequality, also spends less on measures aimed at families and children $(8.0 \%$ and $5.6 \%)$ or on housing and the fight against social exclusion (3.6\% and $1.3 \%)$. 


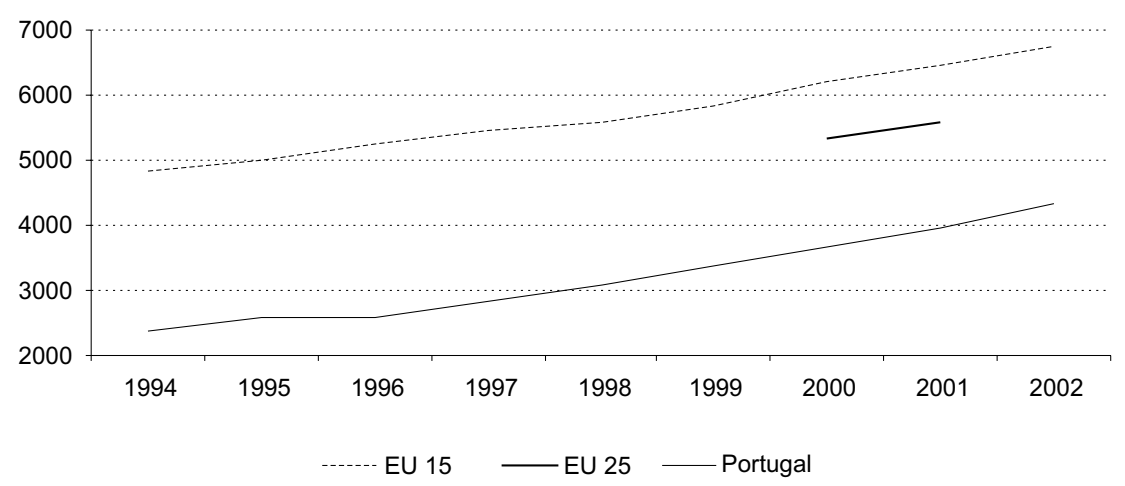

Figure 4.3 Total social protection expenditure in PPS per capita, 1994-2002

Source: European Social Statistics: Social Protection Expenditure and Receipts, Data: 1994-2002, European Commission, Eurostat.

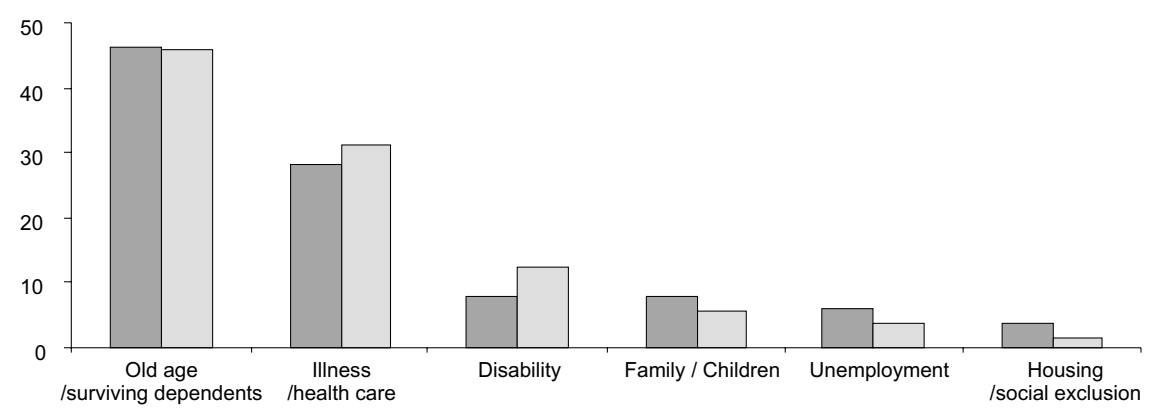

EU $15 \square$ Portugal

Figure 4.4 Social protection by function (\% of total expenditure on social benefits), 2002 Source: Statistics on Focus, Population and Living Conditions, Social Protection, 2004.

The general improvement in the lives of the Portuguese, as reported in the Family Budget Survey of the National Institute of Statistics (INE) (Capucha, 2005), is not unrelated to the effort to raise social expenditure. This effort has had its effects on reducing poverty, a reduction that represents one of the best indicators of social development.

In the period in question, the Social Security system seems to have entered a phase of maturity. According to data from the National Pension Centre 
(Centro Nacional de Pensões), in 2000 there were 1,518,689 recipients of old age pensions (60.9\% of all beneficiaries), 373,337 of disability pensions (15\%), and 602,277 of surviving dependents' pensions (24.1\%). Pensioners constituted $23.8 \%$ of the Portuguese population, representing more than half $(55 \%)$ of all the system's beneficiaries, with the remaining $45 \%$ receiving sickness benefit $(33.5 \%)$, family allowance (5.2\%) and unemployment benefit (only $3.7 \%$ ). ${ }^{12}$

With this maturity, and in view of foreseeable developments on a demographic level ${ }^{13}$ and in employment, work-related income and productivity, the Portuguese system is facing the need for reform in order to maintain future sustainability. There have been two opposing outlooks in Portuguese society, one that accentuates limiting public system responsibilities and stimulating growth in the private sector (Campos, 2000), and another (which prevailed in the new basic law of $2000^{14}$ ) that is centred more on reinforcement of the public system. This new basic law thus reaffirms the primacy of state responsibility in the provision of welfare measures based on inter-generational solidarity, as well as in national obligations towards the most deprived. At the same time, it establishes a set of principles that have been being developed into social policies. These include positively discriminating ${ }^{15}$ on behalf of the neediest, particularly in the pension and family benefit systems; turning the fight against social exclusion into one of the main objectives of the system;

12 The growth of minimum pensions and of their effects is the subject of detailed analysis in another chapter of the trilogy now presented.

13 The index for the aging of the population rose from nearly $85 \%$ in 1995 to more than $95 \%$ in 1999, with the 2001 Census indicating that the elderly population had for the first time overtaken the population under 14 years of age. The dependence index for the old people (the population aged 65+/the population aged 15-64 years x 100) rose from 21.5 in 1995 to 22.8 in 1999.

14 A prospective study carried out in 2001 showed that, at that time, in spite of the inevitable effects of the aging and maturation of the system (with systematic improvements in average pensions values), the phase in which it may face deficit is quite distant, particularly if the alterations made to the law are complied with (in particular, those relating to the creation of a reserve fund) and the non-compliance of the period 2002-2004 is rectified. Sustainability will be better assured not so much through the creation of payment ceilings to stimulate the demand for the private schemes, as mainly through an increase in the effective retirement age and the encouragement of active aging, together with, as a condition of this, an improvement in the quality and attractiveness of work (Santos and Ferreira, 2002).

15 The path towards the fulfilment of this function is also the subject of debate today. One of the topics concerns the principle which the growth in policies regarding income redistribution should follow. If the objective is to raise the living standards of pensioners on the lowest pensions, the relatively more expensive option of universal measures will be favoured. This will be the case with an increase in the general minimum pension to the value of the national minimum salary. If, on the contrary, the objective is to eradicate poverty, an increase in the lowest pensions (in all systems) may assume the form of a means-tested supplement, which would assure that the poverty threshold would be passed with a greater economy of means (Gouveia and Rodrigues, 2003). 
and, finally, reorganising the system so as to make procedures and information flows uniform, bring services closer to the citizens and create horizontal structures of inter-departmental coordination at the various national, regional and local levels. ${ }^{16}$

The new law maintained the three existing bases (the contributory regime, the non-contributory regime and social action) and made fundamental changes to the system, in particular by i) setting the criteria for calculating pensions (optional for those who already had established rights), so as to raise the value of the total contribution by including a person's entire contributory career in the calculation system, ii) establishing the State Budget as the source of financing for social action, and iii) reinforcing Public Capitalisation Funds. Together, with the application of the law, these measures would pave the way for the relative increase in benefits and the system's long-term financial viability.

As we have seen, the expenditure on housing and the fight against poverty remain limited compared to the typical European pattern. It should be noted, however, that the period under analysis was particularly marked by the launch of a set of anti-poverty measures that represented a leap beyond the previous Anti-poverty Programme.

In addition to the integration of concerns about the social inclusion of the most deprived groups in the pension and family benefit systems and the reinforcement of the Anti-poverty Programme, the Social Network programme was created, along with a series of other measures. As a whole, the latter are part of the process of building a new generation of active social policies, with the most significant examples being the Guaranteed Minimum Income and the Social Labour Market.

The Guaranteed Minimum Income (GMI), created by Law 19-A/96, was one of the political issues of the 1995 electoral campaign. The election was won by the Socialist Party, which promised to introduce the measure to comply with a European Council recommendation, approved in 1992, that all EU member states complete their protection systems with policies supporting the income of the poorest groups in the population. The GMI then became a symbolic measure of the period.

Essentially, the plan consists, on the one hand, of a monetary payment from the non-contributory social security system. This payment, conditional on resources, is intended to combat the more extreme forms of economic need and to guarantee a minimum of dignity for all the legal residents of

16 This is the level at which it went the farthest, thanks to the launch of the Social Network Programe (Programa da Rede Social), which, besides bringing new partners (such as local government) to the system of social action, aims to promote systematic action based on rational and negotiated instruments of diagnosis and planning, with a view to resolving (on a local plane and on the basis of contributions from the bodies responsible) all the problems that, on this level, according to the principle of solidarity, may be solved. 
Portugal. On the other hand, the plan consists of an integration programme destined to rectify the situations that have led to penury. This should be offered, with the appropriate quality, by the institutions with which the beneficiaries sign contracts, according to the needs of each person or household. While availability for work is a benefit condition applicable to all those whose age and health allow this, the integration contracts involve many other areas, such as health, education, occupational training, access to social facilities, housing, and social action.

Beneficiaries must previously exhaust all the rights to which they are entitled. When this is the case, the value of the benefit granted consists of the difference between household income per adult-equivalent ${ }^{17}$ - with earnings being subject to a $20 \%$ discount to motivate economic activity ${ }^{18}$ - and the minimum income, set at the value of the social pension.

All legal residents of the country over 18 years of age, in a proven situation of economic need, were able to apply. Likewise, minors with other dependents, pregnant women or young people with a disability were eligible. The composition of the household took into account the applicant, his or her spouse (or resident partner of more than a year), related minors or students, adopted children, wards of the applicant, and other relatives unable to work. The maximum limit of the benefit was 24 times the social pension and at least $5 \%$ of that pension.

As a national measure, the GMI was managed at a local level by Local Attendance Committees (LACs), which were required to include local representatives from the fields of social action, education, employment, health and, optionally, local government, the IPSS (Private Institution for Social Solidarity), the social partners and other not-for-profit organisations. The LACs were responsible for attending to beneficiaries (a task mostly carried out by the local social action services) and drawing up and supervising the Integration Plans to be signed by the LAC representative and all the household members involved.

Along with the principles of decentralised management and the signing of a contract between the beneficiary and society, the GMI broke with previous social action measures by being a right and not a possible "donation" from the social action.

There had been calculation s that $5 \%$ of the population could benefit (Rodrigues, 2001) but the GMI take-up rate was $72 \%$. The measure had an impact (which superseded its objectives) of reducing the poverty rate by $1.6 \%$ and, as intended, there was a $17.7 \%$ reduction in the intensity and a $36 \%$ reduction in the severity of poverty (Rodrigues, 2004).

17 The scale of equivalence is more generous than that of the OECD. In each household, two adults have a weighting equal to 1 , other adults beginning with the third have a weighting of 0.7 and children one of 0.5 . 
According to data from the IDS (Institute for Social Development), the average benefit provided was $€ 150.1$ per household and $€ 51.3$ per beneficiary in December 2002. According to the same source, there were 479,657 applicants, with a rejection rate of $40.5 \%$ (194,099 cases rejected, mainly due to incomes above the minimum or the non-presentation of documentary proof of income). ${ }^{19}$

At first, in 1997, the number of beneficiaries represented 1.2\% of the Portuguese population (after the experimental period from July 1996 to July of that year), growing to $3.4 \%$ in 1998 and reaching a maximum of $4.3 \%$ in 1999 . From then the number started to decrease, to $4.2 \%$ in 2000 , $3.4 \%$ in 2001 and $3.1 \%$ (320,155 individuals and 109,579 households) in 2002. Until December of the latter year, 826,974 people had benefited and 506,819 (belonging to 175,979 households) had already stopped drawing the benefit. Of these, $62.7 \%$ were no longer in economic need. The other reasons were a) failure to complete or register for the integration programme ( $11.5 \%$ and $7.9 \%$ respectively), b) an invalid resident's permit $(1.5 \%)$ and c) other causes $(16.4 \%)$.

Integration contracts reached the figure of 75,379 , covering 173,257 individuals and 229,853 cases of action. Of the latter, those in the area of education $(14.8 \%)$, health (23.6\%) and employment $(15.7 \%)$ are of particular importance. In light of this last figure, it should be noted that $39.9 \%$ of the beneficiaries were under 18 years old, $8 \%$ over $65,24.4 \%$ employed, $9.1 \%$ pensioners, $4.5 \%$ unable to work and $23.8 \%$ students. The unemployed were a group that was over-represented $(19.8 \%)$ and $14.7 \%$ were people involved in with domestic tasks.

As to the type of families, those with lone mothers are clearly over-represented $(21 \%)$, though the $15 \%$ for lone women and $12 \%$ for lone men are also significant. Extended families represented $4 \%$ of the total, married couples without children $14 \%$ and couples with children $33 \%$.

The Social Labour Market is another basic reference point for the new generation of active social policies. In this market, there is perhaps the clearest convergence in the cooperation between two lines of thinking. The first consists of creating compatibility in the provision of economically, socially and ecologically important services. The other consists of the social integration of social categories and groups which, without these measures, would have been unable to gain employment (an opportunity which they had either never had or only had a long time before), acquire skills to make themselves employable or actively participate in social development.

The Social Labour Market is, above all, a solution offering excluded groups a means of transition to the open market (in some cases constituting a more or less permanent solution), by way of the acquisition of basic, personal, 
relational and occupational skills. As such, it consists of a set of activities supported by the state to meet needs that normal businesses do not address. These measures cover the Occupational Programmes for the unemployed, trade-schools, special occupational training, integration enterprises and protected employment for the disabled.

In 2000, 44,631 long-term unemployed people participated in the Occupational Programmes, 5,288 young people were enrolled in trade-schools, 3,109 people were employed by integration enterprises, and 677 disabled people were involved in protected employment. The number of people who belonged to categories such as young people at risk, the homeless, former drug addicts, ex-prisoners, ethnic minorities and others in long-term unemployment situations and who were involved in special occupational training activities totalled around 12,000 in 2002. In the same year, there were around 7,000 disabled people in socio-occupational training-rehabilitation activities.

Portugal also has plenty of room for expansion in this area, given that in 2002, according to the Joint Report on European Employment Strategy, the percentage of the GNP related to expenditure on active labour market policies was only $0.2 \%$, versus $0.7 \%$ in the EU15. We had the worst performance in this area, although we approach the average for passive measures: $1.0 \%$ in Portugal, versus $1.3 \%$ in the European Community - an indicator in which we find ourselves above the United Kingdom $(0.4 \%)$, Luxembourg $(0.5 \%)$, Ireland $(0.7 \%)$, Italy $(0.6 \%)$ and Greece $(0.4 \%)$.

The period of growth in the economy and employment and of the renovation of social policies placed the Portuguese government in a position, during the European Union Presidency in the first semester of 2000, to launch what became known as the Lisbon Strategy (Rodrigues, 2003). Essentially, this strategy consisted of a set of objectives and a method for their promotion. The objectives, each of which was to unfold through a specific action plan, aimed at turning Europe into the most competitive region in the world by 2010, on the basis of the knowledge economy (which would imply a 3\% average annual GDP growth rate), with more and better employment (which meant reaching an employment rate of $70 \%$ by that date, with a $60 \%$ rate for female employment and a $50 \%$ rate for older workers) ${ }^{20}$ and greater social cohesion. ${ }^{21}$ The method used to advance would involve coordinating processes. The Council of Europe affirmed the importance of promoting the transition to the knowledge-based economy within a solid economic framework, while preserving and promoting the quality of the renewed European social model, with human resources being the key capital for this strategy. Thus, the formation of the will of the 
Council should be shaped not only by ministers of finance and the economy, but also the formations in social areas.

To promote the advancement of European policies in areas of subsidiarity, such as employment and social cohesion, an open method of coordination was established as a new tool, which would be set al ongside existing forms of legislation and regulation (Capucha, 2004). Within this framework, it was decided to launch one process of open coordination for the promotion of social inclusion and another for promotion of the sustainability of the pension systems. There have been no visible consequences of the latter in Portugal, though the Laecken Summit in 2001 established common European objectives. Some of these are part of the current debate in Portugal, such as those relating to the adjustment of pension levels, the promotion of incentives to remain in the labour market by making work pay, the establishment of measures for better redistribution of the costs of aging among and within the generations, and the assurance of balances between contribution levels and pension levels, within a framework that guarantees the objectives of the Stability and Growth Pact.

The goal of greater social cohesion has already resulted in a National Action Plan for Inclusion, which responds to the common objectives approved in the Nice Summit of December 2000. The first of these objectives, in its current plan, consists of the promotion of the participation of all in employment, through the various means of access. This includes the social labour market, guidance methods, training and monitoring adapted to people with particular difficulties, the reconciliation of work and family life, and the prevention of job upheavals, by improving the management of human resources and promoting lifelong learning and work organisation. The first objective also covers the promotion of access to resources, rights, goods and services, including social protection, housing, healthcare, education, justice and other public and private services such as those regarding culture, sports and leisure.

The second objective of the Inclusion Strategy consists of preventing the risks of exclusion by fully exploiting the potential of the knowledge society and new information and communication technologies and guaranteeing that nobody is excluded from them. Special attention was given to the needs of people with disabilities and the risks resulting from overindebtedness, as well as to educational exclusion and homelessness. On the other hand, the aim was to preserve the various forms of family solidarity. The third objective is remedial in character and aims to benefit the most vulnerable, particularly by encouraging the social integration of disabled people or those belonging to other groups that, due to special difficulties, are exposed to the risk of persistent poverty, by eliminating the situations of social exclusion that affect children and by promoting overall action on behalf of areas facing exclusion.

The final goal consists of the mobilisation of all entities responsible for the process, including the very people in a situation or at risk of exclusion, the 
national and local authorities, the social and civic partners, and also businesses - stimulating the socially and ecologically responsible channels. Among the above, new forms of coordination and cooperative work are expected to be found.

The response of the National Action Plan for Inclusion to this collection of European goals involved a three-fold strategy. It included i) the promotion of socio-economic development, with particular attention to the fight against the traditional forms of poverty still existing in Portugal; ii) efforts to prevent the risks facing the groups and categories that are most vulnerable to poverty and social exclusion; and iii) action to include groups and categories currently experiencing social exclusion. The strategy attached particular importance to i) policy coordination with a view to stimulating growth and macro-economic equilibrium, a necessary but insufficient condition for effectively fighting poverty within the framework of a transition towards the knowledge-based economy; ii) the conversion of the concern with social cohesion into a standard principle in the design and management of the various social, labour and economic policies; iii) an improvement in the performance and management of social security systems, including the application of the principles of social justice implicit in the adoption of positive discrimination measures; iv) the development of active integration policies, in particular through the promotion of integrated programmes for the eradication of exclusion (involving the creation of family support facilities and services, the development of skills and employability, support for job creation, an improvement in housing and basic infrastructure, security, the prevention of disease and risk behaviour, and cultural and community activities), to be implemented by concentrating resources on the most deprived areas; and finally v), incorporation of the principle of gender equality into all political measures and all agents' practices.

\section{A change of direction in policy: 2002-2004}

The first signs of a change of direction in Portuguese social policies were given when the new centre-right government elected in 2002 proposed a Labour Code which, even after being seriously modified through pressure from the trade union movement, contains matters that the latter considers severely damaging to workers' interests. However, the process of social dialogue that had begun in 2000 (with the signing of the previously mentioned agreements, of moderate reach, on specific strategic themes for employment, education and training, for health, hygiene and safety at work and for the sustainability of the pension system) was discontinued. ${ }^{22}$

The agreement on salaries and productivity was not concluded, nor was legislation passed on a large part of the matters agreed upon. 
At the same time, the new basic social security law was put into question, mainly in order to lower contribution ceilings for the sake of stimulating the private market. Ultimately, the result of these intentions was more limited than had been formally intended. However, on a practical plane, policy management measures were suspended, e.g. the modernisation of the system's organisations (represented, for example, by the launch of the Social Solidarity Walk-in Centres, intended to bring services closer to Social Security beneficiaries and contributors, or the appointment of specialist staff to renew social action management) and a certain impasse developed: the law did not change as the government wished, nor did it become effective in practice.

The GMI also underwent alterations, in particular with proposals to restrict the conditions of access. The unconstitutionality of a great part of the proposals for reformulating the law limited the reach of these modifications. Ultimately, however, the process damaged the measure, which meanwhile changed its name to Social Integration Income (SII). One of the principles that has generated the most criticism is the rule of using the last 12 months' income to calculate benefits, an approach that prevents a response to the needs of families facing, for example, the end of unemployment benefits and a long wait for the right to a pension. Another principle is the need to re-apply for benefits every year (an automatic process under the GMI), with the result of an increase in bureaucracy. A third consists of the use of bureaucratic criteria to assess applications, so that candidates are confronted with requests for documents that they are unable to provide and their applications are automatically rejected. Such principles help to explain the decrease in SII beneficiaries in relation to those of the GMI (134, 466 in May 2005 and 286,491in May 2003, respectively). This fact raises serious questions about the effectiveness of the new measure, which should be a remedial mechanism for the effects of a socio-economic situation that has worsened. Nevertheless, the statistical information available does not allow a clear conclusion to be drawn on the dynamics in progress, given that data is not provided on the number of ex-GMI beneficiaries who requested the SII and whose cases are still being analysed.

Though of inadequate quality, the data available on the execution of the SII (based on an initial report for internal use in the Social Security services) reveals a structure for the measure identical to that of the GMI. Of those involved in the SII, 39\% are less than 18 years old and $6 \%$ are over 65 (under the GMI the values were $40 \%$ and $8 \%$, respectively), the rates of rejection are equal (nearly $40 \%$ in both cases), as are the reasons (78\% due to too high incomes in the SII versus $79.3 \%$ in the GMI), and there are also similar situations regarding work and the average benefit ( $€ 59.27$ per household per month in February 2005). But with reference to the integration processes, despite the fact that improving them is a commitment symbolised by the changed name of the measure, the beneficiaries placed in integration programmes went 


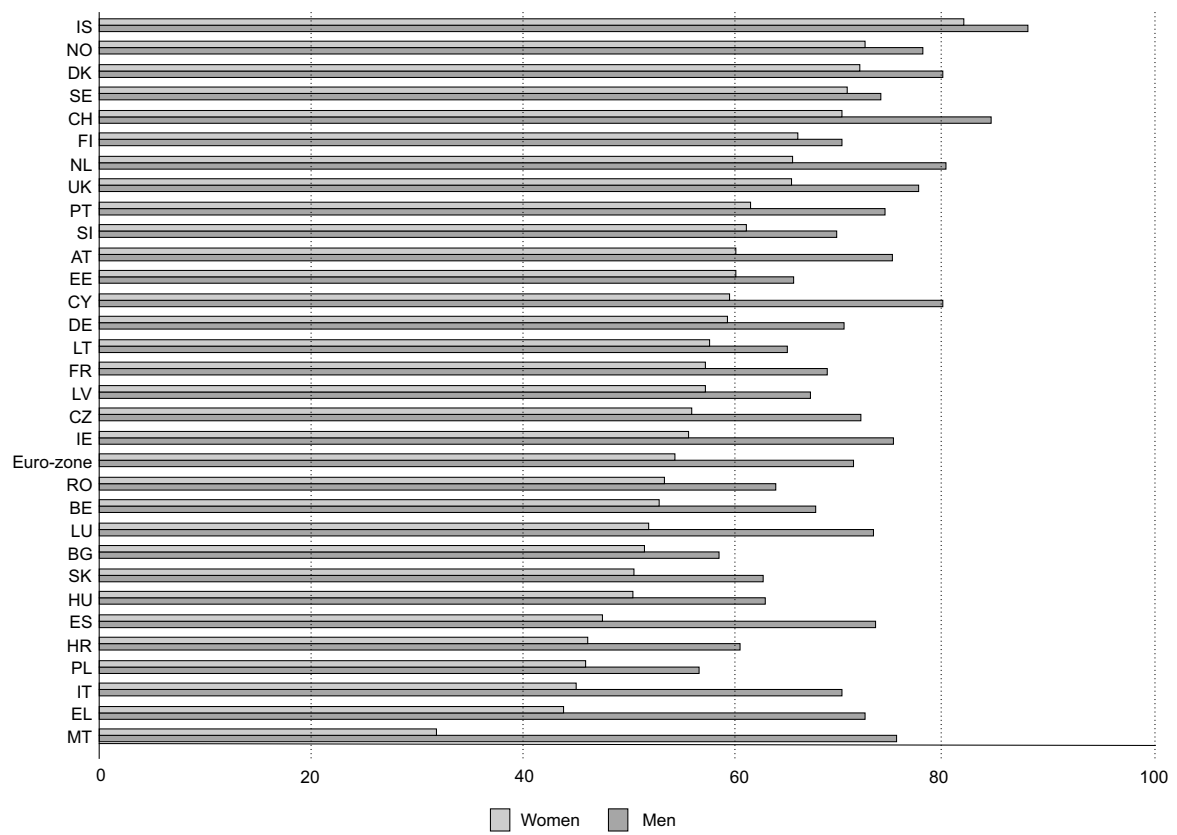

Figure 4.5 Employment rate in the EU 25, by sex, 2004Q2 (\%)

Source: Statistics on Focus, Population and Social Conditions: Main Results from the EU of Labour Force Survey.

down from 54.1\% in December 2002, under the GMI, to merely $20.2 \%$, under the SII, in February 2005.

The deterioration in the socio-economic situation was also particularly felt on the labour market. In 2001 and 2002, though unemployment began to rise, productivity only increased by $0.2 \%$ each year. In 2003 , there was even negative growth of $-0.4 \%$. In the first quarter of 2004, productivity growth was once again positive, though only $0.1 \%$ (DGEEP, Relatório de Conjuntura [Joint Report]).

The employment system presents values which continue to be positive compared to those of Europe, though they have been worsening. Portugal is the sixth country among the current EU25 in terms of the total employment rate and has the eighth highest rate of female employment, placing itself clearly above the average in every indicator.

The activity rate is among the highest and has registered continuous growth (the comparable variations are located within the values of $1.5 \%$ for 2000 and 2001 , and $0.4 \%$ for 2004 , with the only negative value, $-0.1 \%$, being found for men in 2003), as table 4.1 shows.

The employment rate has fallen in recent years, in spite of maintaining, as has been said, higher levels than the European average. As we saw 
Table 4.1 Main indicators of the labour market

\begin{tabular}{|c|c|c|c|c|c|c|}
\hline & 2000 & 2001 & 2002 & 2003 & $2003^{*}$ & $2004^{* *}$ \\
\hline \multicolumn{7}{|l|}{ Labour force (>= 15 Years) } \\
\hline Total & 5234,5 & 5314 & 5378,8 & 5408,8 & 5460,3 & 5471,9 \\
\hline Men & 2857,1 & 2892,8 & 2918,2 & 2915,7 & 2947,9 & 2953,5 \\
\hline Women & 2377,4 & 2421,2 & 2460,6 & 2493,1 & 2512,4 & 2518,4 \\
\hline \multicolumn{7}{|l|}{ Activity rate (15-64 Years) } \\
\hline Total & 71.3 & 71.7 & 72.0 & 72.0 & 72.8 & 72.8 \\
\hline Men & 79.0 & 79.2 & 79.3 & 78.5 & 79.4 & 79.0 \\
\hline Women & 63.8 & 64.5 & 65.0 & 65.6 & 66.5 & 66.7 \\
\hline \multicolumn{7}{|l|}{ Persons in employed ( $>=15$ Years) } \\
\hline Total & 5028,9 & 5098,4 & 5106,5 & 5064,2 & 5118,0 & 5124,6 \\
\hline Men & 2767,7 & 2799,7 & 2796,3 & 2753,8 & 2787,1 & 2787,6 \\
\hline Women & 2261,3 & 2298,7 & 2310,3 & 2310,4 & 2330,9 & 2336,9 \\
\hline 15-24 Years & 622,9 & 637,2 & 629,6 & 582,1 & 528,8 & 494,8 \\
\hline \multicolumn{7}{|l|}{ 55-64 Years } \\
\hline Self employed & 1184,2 & 1251,1 & 1256,1 & 1261,0 & 1227,6 & 1227,7 \\
\hline Employees & 3651,8 & 3705,2 & 3732,4 & 3699,4 & 3736,0 & 3798,8 \\
\hline Permanent job & 2926,5 & 2948,8 & 2921,3 & 2919,8 & 2967,5 & 3044,5 \\
\hline Temporary job & 725,4 & 756,4 & 811,1 & 779,6 & 768,6 & 754,2 \\
\hline \multicolumn{7}{|l|}{ Employment rate (15-64 Years) } \\
\hline Total & 68.3 & 68.6 & 68.1 & 67.1 & 68.0 & 67.9 \\
\hline Men & 76.4 & 76.5 & 75.7 & 73.9 & 74.8 & 74.3 \\
\hline Women & 60.5 & 61.0 & 60.8 & 60.6 & 61.4 & 61.7 \\
\hline 15-24 Years & 42.0 & 42.7 & 41.9 & 38.4 & 38.5 & 36.9 \\
\hline 55-64 Years & 50.8 & 50.1 & 50.9 & 51.1 & 51.6 & 50.1 \\
\hline \multicolumn{7}{|l|}{$\begin{array}{l}\text { Employees with temporary jobs/ } \\
\text { Total employees }\end{array}$} \\
\hline & 19.9 & 20.4 & 21.7 & 21.1 & 20.6 & 19.9 \\
\hline \multicolumn{7}{|l|}{ Unemployed persons (>= 15 Years) } \\
\hline Total & 205,6 & 215,6 & 272,3 & 344,5 & 342,3 & 347,3 \\
\hline Men & 89,4 & 93,2 & 122,0 & 161,9 & 160,9 & 165,9 \\
\hline Women & 116,2 & 122,5 & 150,3 & 182,7 & 181,5 & 181,4 \\
\hline 15-24 Years & 58,4 & 66,2 & 82,2 & 99,3 & 89,4 & 80,5 \\
\hline $55-64$ Years & 18,9 & 18,5 & 22,2 & 26,2 & 26,3 & 34,7 \\
\hline Up to Basic Education , $3^{\text {rd }}$ Cycle & 160,9 & 168,1 & 209,9 & 258,3 & 255,5 & 268,1 \\
\hline Secondary and Higher Education & 44,8 & 47,6 & 62,4 & 86,2 & 85,9 & 79,3 \\
\hline \multicolumn{7}{|l|}{ Unemployment rate (>= 15 Years) } \\
\hline Total & 3.9 & 4.1 & 5.1 & 6.4 & 6.3 & 6.3 \\
\hline Men & 3.1 & 3.2 & 4.2 & 5.6 & 5.5 & 5.6 \\
\hline Women & 4.9 & 5.1 & 6.1 & 7.3 & 7.2 & 7.2 \\
\hline 15-24 Years & 8.6 & 9.4 & 11.5 & 14.6 & 14.5 & 14.0 \\
\hline 55-64 Years & 3.2 & 3.2 & 3.7 & 4.3 & 4.3 & 5.7 \\
\hline \multicolumn{7}{|l|}{$\begin{array}{l}\text { Long term unemployment/ } \\
\text { Total unemployment }\end{array}$} \\
\hline Total & 43.6 & 39.8 & 37.2 & 37.4 & 37.8 & 44.7 \\
\hline Men & 45.6 & 39.6 & 35.8 & 34.9 & 35.0 & 44.7 \\
\hline Women & 42.5 & 40.0 & 38.3 & 39.6 & 40.2 & 44.7 \\
\hline
\end{tabular}

Source: INE, Inquérito ao Emprego; * new series; ${ }^{*}$ second quarter of 2004. 
above, the rate registered increases after 1995 and also maintained positive growth in 2000 and 2001. The values were inverted and became negative in 2002, 2003 and 2004, in the first two years due to a decrease in employment for young people and, in 2004, also due to a decrease in workers over 24 years of age. Men suffered considerably more than women, for whom the development was also negative. On the whole, we went from an employment rate of $68.3 \%$ in 2000 to one of $67.9 \%$ in 2004, with the rate of female employment rising from $60.5 \%$ to $61.7 \%$ and the young people's employment rate falling from $42.0 \%$ to $36.9 \%$.

Permanent jobs increased by $1.0 \%$ in 2000 and $0.8 \%$ in 2001, decreasing by $0.9 \%$ in 2002 and $0.1 \%$ in 2003, and then increasing again in 2004, this time by $2.9 \%$. The proportion of non-permanent jobs, which in 2000 had already reached $19.9 \%$ of employees, increased further still, with positive growth of $8.9 \%$ in $2000,4.3 \%$ in 2001 and $7.2 \%$ in 2002 . Only in 2003 and 2004 did this amount decrease, by $3.9 \%$ and $1.9 \%$ respectively. In the latter year, it once again represented $19.9 \%$ of all work contracts involving employees, after reaching a maximum of $21.7 \%$ in 2002 , a year in which the average value in the EU15 was $9.7 \%$.

If the development in employment has been negative, that of unemployment has been even more unfavourable. In 2000, unemployment reached a historically low rate of $3.9 \%$. Since then, it has continued to grow, slowly in 2001 (comparable growth of $4.9 \%$ ) and later more rapidly (26.3\% in 2002, $26.5 \%$ in 2003 and $4.2 \%$ in 2004). In the latter year (second quarter), the total unemployment rate was $6.3 \%$ (2.4 percentage points higher than in 2000). Overall, the period was relatively more unfavourable to men than women. The variations in male employment were $-17.9 \%, 4.2 \%, 30.9 \%, 32.9 \%$ and $9.6 \%$ respectively in 2000, 2001, 2002, 2003 and 2004, while the values for women in the same years were $-1.4 \%, 5.4 \%, 22.7 \%, 21.5 \%$, and $-0.3 \%$. Thus, though women continued to be more vulnerable (the female unemployment rate was $7.2 \%$ in 2004 versus $5.6 \%$ for men), the difference diminished by 0.1 percentage points between 2000 and 2004 (in 2000, the respective rates were $4.9 \%$ and $3.1 \%$ ).

The young people have clearly been the most affected. The unemployment rate of young people was $8.6 \%$ in 2000 (when they represented $28.4 \%$ of the unemployed), increasing to $14.5 \%$ in 2004 (23.1\% of the total).

One final feature to note in the Portuguese employment statistics relates to the high representation of long-term unemployment (LTU - those unemployed for more than 12 months). This group accounted for $43.6 \%$ of the total unemployed in 2000, a proportion that remained around $40 \%$ until 2004, when it reached $44.7 \%$. 


\section{Challenges for the future}

A combined reading of the employment statistics and economic indicators presented above, along with the poverty indicators, allows an insight into certain weaknesses in the Portuguese employment system. These shortcomings are challenges for the social development policies to be embarked upon in the future.

One of these weaknesses concerns the structural deficit in qualifications. Educational levels have developed positively, but so slowly that the gap is growing between our country and the rest of the EU. It is true that, considering the population aged 25-64 years, the percentage without any level of schooling decreased from 22.4 in 1991 to 11.3 in 2001 and the population with only the basic education $1^{\text {st }}$ cycle also went down from $44.4 \%$ to $35.9 \%$. On the other hand, there was a rise in the proportion of those who have completed the basic education $2^{\text {nd }}$ cycle 2 and basic education $3^{\text {rd }}$ cycle/lower secondary (from $10.8 \%$ to $15.1 \%$ and $7.4 \%$ to $13.4 \%$ respectively), upper secondary (from $8.4 \%$ to $13 \%$ ) and higher education (from $6.7 \%$ in 1991 to $10.6 \%$ in 2001) (INE, Censos 1991 and 2001). However, these values do not resolve the distortion in the structure of Portuguese educational qualifications - a fact that makes the common affirmation that there are too many graduates in our country seem quite unreasonable - mainly regarding the proportion of those who have completed upper secondary education, as can be seen in table 4.2.. ${ }^{23}$

A supply of employment that does not stimulate the demand for intermediate or higher qualifications (because it does not always offer careers paths compatible with the qualifications acquired) and an educational and training system that is out of step with real market needs (though they are not clear to see) are factors that contribute to early school leaving rates ${ }^{24}$ of around $45.5 \%$ in Portugal, versus only $18.8 \%$ for the European average (European Commission, Joint Employment Report 2004). Furthermore, this indicator is falling faster in the rest of Europe than in our country, a fact that puts us in a more and more fragile position.

This data shows that, even if it is possible to sustain the thesis of a split between the generations on the level of education, with the young people being more educated than the active adult and elderly population, it can be of little comfort. This is all the more so since the proportion of workers with low qualifications is 2.9 times greater than those with higher qualifications $(3,759,300$

23 The number of workers with high qualifications rose from 1, 062, 400 in 1999 to 1, 083, 500 in 2002; the number of workers with low qualifications rose from 3, 829, 300 in 1999 to 3,993, 100 in 2002 (INE, Inquérito ao Emprego [Employment Survey]).

24 According to the official European indicator, the proportion of young people between the ages of 18 and 25 who are not studying or undergoing training and who have not completed upper secondary level. 


\begin{tabular}{lcc}
\hline & Portugal & UE15 \\
\hline To lower secondary level & 79.4 & 35.4 \\
To upper secondary level & 11.3 & 42.9 \\
Higher education & 9.4 & 21.8 \\
\hline
\end{tabular}

Source: Labour Force Survey.

versus 1,331,900 in the second quarter of 2004) and the indicator of training course participation is also of particularly serious concern in our country, ${ }^{25}$ with a value of $2.9 \%{ }^{26}$ versus $8.5 \%$ for the EU15 average (European Commission, 2004). Though Greece (1.2\%) and France (2.4\%) have worse levels, Spain presents a value almost double our own (5\%), while Finland (18.9\%), Denmark $(18.4 \%)$, the Netherlands (16.4\%), Sweden (18.4\%) and the United Kingdom $(22.3 \%)$ find themselves at the levels that Portugal needs to attain in order to catch up with the others. This is of decisive importance in the transition to the information society and knowledge-based economy.

When investment by the state, through the support of the Structural Funds, is compared to the European average in terms of volume (in spite of the problems of effectiveness that have been identified ${ }^{27}$ ), Portuguese companies are seen to be much less committed to investing in the ongoing training of their workers than their European counterparts, as the previously mentioned European Commission report reveals.

A second area of great weakness in the Portuguese employment system concerns the sectoral structure. We have already seen how the recent development in the GNP and productivity betrays this fragility. As can be seen in table 4.3, Portugal diverges from the European pattern, having a higher weight of sectors such as construction, agriculture, forestry and fisheries, and a lower one in services, particularly in services for businesses and in financial, real estate and rental activities.

On the other hand, the lower investment in decisive factors for innovation and the transition to a knowledge-based economy, which we have mentioned in relation to ongoing training, is explained by the under-qualification of

25 This indicator corresponds to the percentage of active persons who participated in educational or training activities in the month prior to the date of the survey (INE, Inquérito ao Emprego [Emplyment Survey]).

26 As in education, women present a more positive behaviour than men, with a value of $3.3 \%$ versus $2.4 \%$.

27 Regarding this issue, see, for example, the interim evaluation of the Operational Employment, Training and Social Development Program (Programa Operacional Emprego, Formação e Desenvolvimento Social) and, in an even clearer form, that of Operational Education Programme (PRODEP). 


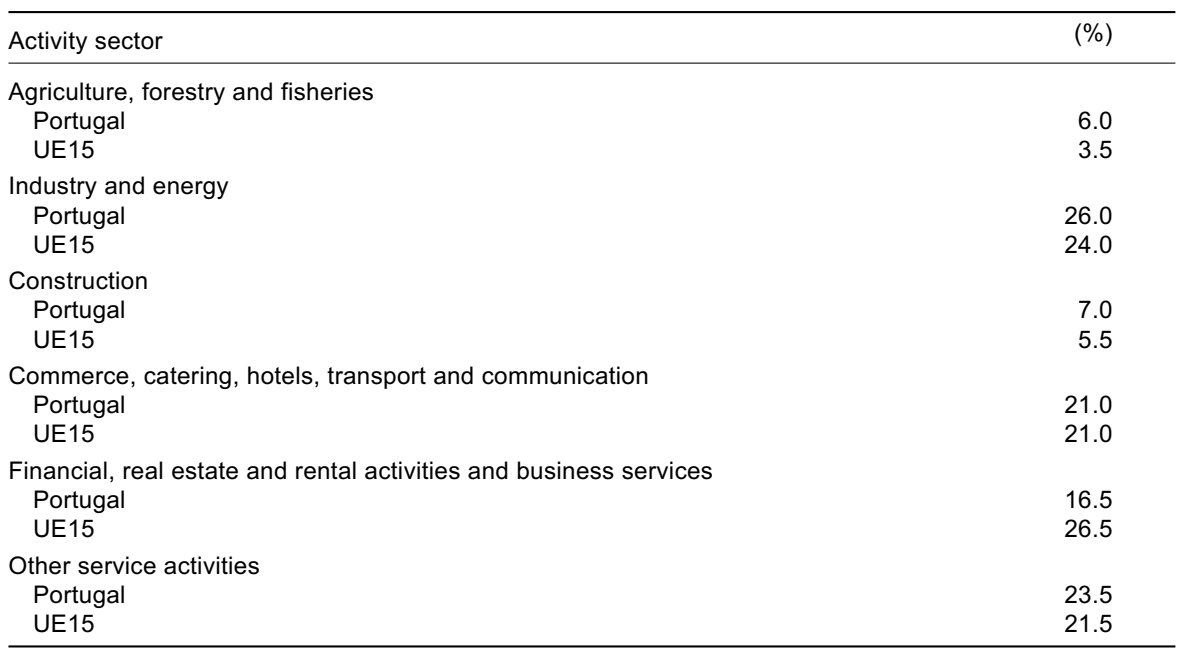

Source: Eurostat, Production and Productivity in the EU, Theme 2, 2000 Edition.

businessmen (who are generally less educated than employees) and by the limited size of businesses. This lower investment is also evident in the resistance to the adoption of modern forms of work organisation which would make it more compatible with family life, richer from the task viewpoint, more democratic from the viewpoint of human relations, and more efficient with regard to the orientation towards goals and the participation of workers in the decision-making and modernisation process.

In Portugal, along with the extremely high number of self-employed workers, there were around 284,006 businesses registered by Quadros de Pessoal (Staff Charts) in 2001, of which $82.7 \%$ had a staff consisting of less than 10 people and $92.3 \%$ less than 20 people. The fact that matters relating to the quality of work and "flexibilisation and security" were practically absent in the salary relationship in the rarefied system of collective contracts is an unmistakable indicator of the difficulties that exist in the transition from a model based upon low salaries to another based upon innovation in business and in organisations in general.

This problem is reflected in the way references to goals relating to sectoral re-conversion and preventative action have disappeared from the most recent versions of the National Labour Plan. On the one hand, these goals would support business modernisation (not only in the technological area, but also in areas of employment organisation and the development of human resources) and, on the other, construct support programmes for the transition 
of workers in sectors at risk to other sectors, with a high potential for growth, such as those of personal and domestic services or the environment.

Thus, less competitive businesses have mainly survived at the cost of the compression of salaries - whose effective value rose $3.1 \%$ in 2000 and only $0.7 \%$ in 2001 and $0.8 \%$ in 2002, to fall around $0.4 \%$ in 2003 (DGEEP, Quadros de Pessoal [Staff Charts]). For this reason, the total number of poor workers in Portugal, adding in employees and self-employed workers, may be close to 720,000 (Capucha, 2004).

This indicator leads us to a third structural flaw in the labour market: that of poverty ${ }^{28}$ and the persistence of groups with particular difficulties in achieving integration. The proportion of long-term employment in total unemployment figures partially reflects this situation, though it in no way gives a complete account of the extent and the complexity of the problems of disheartened unemployment or the absence of the minimal conditions for employability, which is frequently linked with discrimination against certain categories.

Among these groups, we find families with a lone mother who does not possess high qualifications and, as a result, is unable to participate in professions that pay enough to cover childminding. This explains the high rate of exclusion from the labour market and the high access to measures such as the GMI. In 2001, these families represented $11.5 \%$ of the total, with the poverty rate among them being $37 \%$ and the inactivity rate $26.9 \%$ (INE, Recenseamento Geral da População 2001 [Portuguese Census 2001]; European Community Household Panel, 2001).

Another deprived group is composed of migrant populations that belong to poorly paid, unstable and less protected sectors of the labour market. They often possess positive attitudes to work and in certain cases (e.g. migrants from Eastern Europe) higher qualifications than those being used. They are concentrated in labouring occupations, in particular construction, the hotel business and tourism, and personal and domestic services (in the case of women). These workers are often discriminated against with regard to pay, are victims of illegal labour and are subject to highly precarious employment conditions. As a result, poverty, intermittent employment and unemployment, and the subjection to working conditions that offer neither rights nor dignity characterise many immigrants' relationship with the job market. The numbers involved are growing: the 2003 National Labour Plan assumes that they might already represent $5 \%$ of those residing in and $9 \%$ of those active in Portugal.

The disabled compose another particularly deprived group. It is true that the rehabilitation system, with the support of the Structural Funds and, 
in particular, the European Social Fund (Capucha et al., 2004) has obtained some results, namely in helping more than $70 \%$ of the members of this group find work of comparable quality after receiving training. It is also true, however, that unemployment reaches nearly $20 \%$ among those who have been involved in rehabilitation programmes and the rate of economic activity in this group is only 29\% (INE, Recenseamento Geral da População 2001 [Portuguese Census 2001]).

We can also add drug addicts, the homeless, young people at risk and ex-convicts to the categories that are particularly affected by occupational exclusion in Portugal, which, as we have seen, is combined with a high proportion of long-term unemployment, low qualification levels and low average job quality. This combination shows the complexity of the problems in the labour market, principally if we are focusing on the challenges presented by the objective of a transition towards the information society.

The question that is currently being asked regarding employment and social development policies relates to the political imagination and the negotiation of interests to combine growth stimuli and the modernisation of the economy with the upgrading of work, the maintenance of high employment figures and the development of active social protection and anti-poverty policies that set the country back on a converging path with Europe with regard to levels of cohesion and the quality of society.

\section{References}

Campos, António Correia de (2000), Solidariedade Sustentada. Reformar a Segurança Social, Lisbon, Gradiva.

Capucha, Luís (2004), “O método aberto de coordenação das políticas sociais na União Europeia: alcances e limites", in José Leite Viegas, António Costa Pinto, and Sérgio Faria (eds.), Democracia, Novos Desafios e Novos Horizontes, Oeiras, Portugal, Celta Editora.

Capucha, Luís (2005), Desafios da Pobreza, Oeiras, Portugal, Celta Editora.

Capucha, Luís, et al. (2004), Os Impactos do Fundo Social Europeu na Reabilitação Profissional das Pessoas com Deficiência em Portugal, Vila Nova de Gaia, Portugal, Centro de Reabilitação Profissional de Gaia.

Carneiro, Roberto (ed.) (2003), Avaliação do Impacto da Estratégia Europeia para o Emprego em Portugal. Estudo Econométrico com Aferição Qualitativa, Lisbon, DEPP/MTS.

Costa, Alfredo Bruto da, et al. (1985), A Pobreza em Portugal, Lisbon, Caritas.

DEPP/MTS, Departamento de Estudos, Prospectiva e Planeamento do Ministério do Trabalho e da Solidariedade, Carta Social 2002.

DEPP/MTS, Departamento de Estudos, Prospectiva e Planeamento do Ministério do Trabalho e da Solidariedade, Plano Nacional de Emprego 2001 (National Employment Plan 2001). 
DGEEP, Direcção-Geral de Estudos, Estatística e Planeamento, Quadros de Pessoal 2000, 2001, 2002 and 2003 [Staff Charts].

DGEEP, Direcção-Geral de Estudos, Estatística e Planeamento, Relatórios de Conjuntura [Joint Reports] 2001, 2002, 2003 and 2004.

European Comission, Joint Employment Report 2004.

European Commission (2005), Social Protection, Expenditure and Receipts. Data 1994-2002, Luxembourg, Office for Official Publications of the European Communities.

Eurostat, Labour Force Survey.

Ferreira, Leonor Vasconcelos (in press, 2005), Social Protection for Chronic Poverty. Risk, Needs and Rights, Protecting What? How?, FEP Working Papers.

Gouveia, Miguel, and Carlos Farinha Rodrigues (2003), Para que servem as pensões mínimas?, $2^{\text {nd }}$ Conference of the Banco de Portugal, cyclostyled.

Guillén, Ana, and Pedro Adão e Silva (2001), Redesigning the Spanish and the Portuguese Welfare States. The Impact of Accession into the European Union, Working Paper 85, Florence, Centre for European Studies.

INE, Instituto Nacional de Estatística (Statistics Portugal), Recenseamentos Gerais da População 1991 and 2001 (Portuguese Census 1991 and 2001).

INE, Instituto Nacional de Estatística (Statistics Portugal), Contas Nacionais Anuais (Annual National Accounts).

INE, Instituto Nacional de Estatística (Statistics Portugal), Inquérito ao Emprego (Employment Survey).

INE, Instituto Nacional de Estatística (Statistics Portugal), European Community Household Panel 2001.

MTS, Ministério do Trabalho e da Solidariedade (Ministry of Labour and Social Solidarity), Plano Nacional de Acção para a Inclusão 2001 (National Action Plan for Social Inclusion).

OIT, Organização Internacional do Trabalho (2003), A Luta Contra a Pobreza e a Exclusão Social em Portugal, Experiências do Programa Nacional de Luta Contra a Pobreza, Genebra, Bureau Internacional do Trabalho.

Rodrigues, Carlos Farinha (2001), Anti-poverty Effectiveness and Efficiency of the Guaranteed Minimum Income in Portugal, Working Paper 08/2001/DE/CISEP, ISEG.

Rodrigues, Carlos Farinha (2004), The Redistributive Impact of the Guaranteed Minimum Income Programme in Portugal, Working Paper 09/2004, ISEG.

Rodrigues, Maria João (2003), A Agenda Económica e Social da União Europeia: A Estratégia de Lisboa, Lisbon, Publicações Dom Quixote.

Santos, Nuno, and Carla Ferreira (2002), Portuguese Pension Reform. A Preliminary Assessment, Siguna, Sweden, Ninth International Research Seminar on "Issues in Social Security".

Silva, Manuela (1984), “Uma estimativa da pobreza em Portugal em 1974”, Cadernos de Ciências Sociais, 1, pp. 117-128. 



\title{
The democratisation of school education in Portugal
}

\author{
João Sebastião and Sónia Vladimira Correia
}

\section{Massification and democratisation}

The subject of the debate

The profound changes in the structure of qualifications in Portuguese society, which began around 35 years ago and have accelerated clearly in the last 20 years, have brought to the public debate expressions such as democratisation, massification, disqualification of diplomas and freedom of education. The newness of almost generalised nine years of basic schooling, introduced decades ago in the rest of Europe, has resulted in a wave of criticism of the education system, generically focusing on the idea of a profound deterioration in state education and an "evident" decrease in students' skills and competences. It is interesting and in part paradoxical that this achievement is being called into question at a time when, after a hard road of around two centuries, we finally achieve one of the most repeated political objectives, the generalisation of basic education. There are very different reasons and arguments behind these questions, which need to be discussed.

On the one hand, we have the heirs to the debates held for decades for the democratisation of education. They included pedagogical activists, teachers and researchers who were normally left-wing or connected to trade union associations. In the other field is a mixture of conservative elitists, opinion-makers in the different media and different types of economic interests (ranging from those interested in privatising substantial parts of state schools for their own gain to utilitarianists in favour of shorter courses essentially designed to serve the business world's immediate needs). In the debate on the democratisation of education the two positions are radically opposed and the supporters of the first position flatly refuse to question the existing errors and blockages and regard any criticism as an attack on state schools, while the 
second hides the progress made and only manages to find in state schools errors and defects that can only be solved by partial or for some more radical thinkers total privatisation.

As Vallet says, "A meticulous, persistent analysis of the facts is a mandatory stopover on the way to the understanding and intelligibility of societies" (Vallet, 2001: 188), in particular in a debate on education that lives essentially on convictions. It is this type of debate that we wish to avoid, as the clear ideological bias implicit to it prevents a distanced assessment, which is essential to producing valid scientific knowledge.

In view of the expansion of schooling to all strata of Portuguese society, it is important to know what type of mass schooling we have implemented, whether this schooling is moving towards actual progression in equal opportunities or whether, on the contrary, social origin is still a decisive factor in the possibility of progressing successfully to the system's different levels. What exactly is democratisation of education, as an expression of the application of the right to education? How do we evaluate it in such a particular period as that of compulsory basic schooling?

\section{Generalisation, democratisation and massification}

The generalisation of basic education in recent decades has resulted in considerable growth in secondary post-ninth-grade education, resulting in an intense political debate on the role of education in economic and social development. The appearance of a relative "disenchantment" was the most visible symptom of the profound changes in education systems resulting from their generalisation/massification and this raises a whole series of new questions, which include three main types of problem.

First, there is the need to manage larger and larger and therefore increasingly expensive education systems, and the need to raise funds to finance them is a permanent problem. As Coleman pointed out, the question of equal opportunities in education for the different social groups arises not only in equal distribution of resources but also and mainly in available resources (Coleman, 1990:36). Levels of funding and their differentiated sharing are obviously a source of inequality, which needs to be pointed out, even if it is not actually the subject of this article.

Second, the loss of legitimacy is a result not only of the "disenchantment" factors mentioned above, but also of difficulties in the pedagogical management of masses of socially and culturally heterogeneous students. Indeed, this is one of the hardest problems to solve, as the diversity of cultural references, cognitive universes, learning rates and motivations is incompatible with the still dominant teaching models based on formal equality of treatment. As pointed out by Augusto Santos Silva (2002) this is one of the problems that most marks mass schools, as it is a constant source of 
conflict. The curricular unification process ${ }^{1}$ that has taken place all over Europe since the late 1950s, mainly spurred by sociological research into education, has made a significant contribution to the transformation of school populations and their aspirations. In Portugal, this untimely transformation took place at a time when some voices were being raised against it (including Benavente, 1976; Perrenoud, 1986; Bourdieu and Champagne, 1992), after finding that not all its effects were positive, particularly those resulting from repeated failure or unqualified dropouts. As a political strategy for the promotion of equal opportunities, it ended up turning into an element untouchable by the teaching community and it was clear that "the ostensive hostility against what people want to signify differentiation of processes and diversification of pedagogical answers in basic schooling for all and diversification of ways and forms of secondary education in the name of 'democratic' unity of basic and secondary education is merely symmetrical and not truly the opposite of the elitist visions that they wish so much to reject" (Silva, 2002: 192). The question now is knowing how to deal with a system with a broad egalitarian base that does not allow its principles to be questioned but also penalises the same social strata that it formally seeks to promote. As Ana Benavente says, it is imperative to break the identification "between equality as a synonym of uniformity, considering that equality is built in a diversity of responses" (Benavente, 2001:13), an essential condition for the real achievement of a minimum amount of basic learning by all students.

Where basic education is concerned, the debate is rare and opinions are normally contradictory. Some say that the generalisation of basic education and the extension of post-basic levels has inevitably resulted (or will result) in a reduction in educational inequalities only because of individual differences, while others argue that the relevant inequalities are now those coming from inequalities of gender, ethnic origin or nationality.

Finally, with the lack of differentiation of many school diplomas resulting from their massification, different social groups have changed their attitudes to school. This has been reflected in a wide variety of strategies and forms of pressure on the system as a whole or on the schools themselves. There are not only the "traditional" parent associations but also interest groups that try to influence the change in the education system towards privatisation or at least reorientation of internal vocational processes and more freedom of choice for families.

In Portugal, the debate on the democratisation of education was smothered for the decades of the Estado Novo, which was averse to controversies

1 It was the end of the vocational orientation at very low levels of the education system (end of primary education) to develop progressive unification of substantial parts of technical and high-school education. In Portugal, this occurred only in 1974/75 although pressures for unification concomitant with those for the extension of compulsory schooling had existed since the 1960s. 
questioning its strongly retrograde position on education. It returned with the political changes during the so-called "Marcelo spring" and public discussion on the reform of education encouraged by Veiga Simão as of 1971.

The resumption of a debate after such a long time had to be marked by the cultural, political and socioeconomic changes that had taken place in the meantime, but particularly at the beginning by the political context, which resulted in an indissociable link between democratisation of education and political democratisation. This second major debate period was initially marked by the non-democratic political scenario, but it already basically reflected the issues raised by the onset of the process of irreversible massification of the Portuguese education system that began in the late 1950s (Grácio, 1997). This development was due in part to Portugal's participation in the OECD's Mediterranean Project, which helped to break the almost total inertia in education after the Second World War, strongly marked by the political repression of teachers and students.

Particularly intense at the start of the debate and implementation of Veiga Simão's Education Reform, it lasted throughout the 1970s and ended with the approval of the Basic Law on Education in 1986. As was to be expected from such a long period, it was not exactly a uniform debate on the issue of democratisation. It focused on several aspects, such as inequalities of access to education, democratic management, failure and dropping out, national exams in secondary education, fees in higher education, among others. There was, however, one fundamental point. The question of social inequalities in school was now an inevitable issue in the debate for all levels of education. It is also interesting to see that the myth of the role of the school as a central agent of change in society was still well ingrained in the political and pedagogical imagination.

Considering these reflections and looking at available data, we will make a brief assessment of the state of affairs regarding the democratisation of education. We will analyse it from a broad point of view, examining the dissemination of schooling in the population by region, the progression of its relationship with know-how and social inequalities while leaving out the problems of ethnicity and gender, as there are no systematic, diachronic studies on these two issues of great social relevance.

\section{Portugal, 1981-2001: some indicators of democratisation}

\section{A disproportionate education pyramid}

Over the last two centuries, the task of creating a literate population has been marked by slowness, retreats and resistance. It was slow in expanding the school network and increasing the social demand for education. There were advances and retreats in approving and implementing universal education 


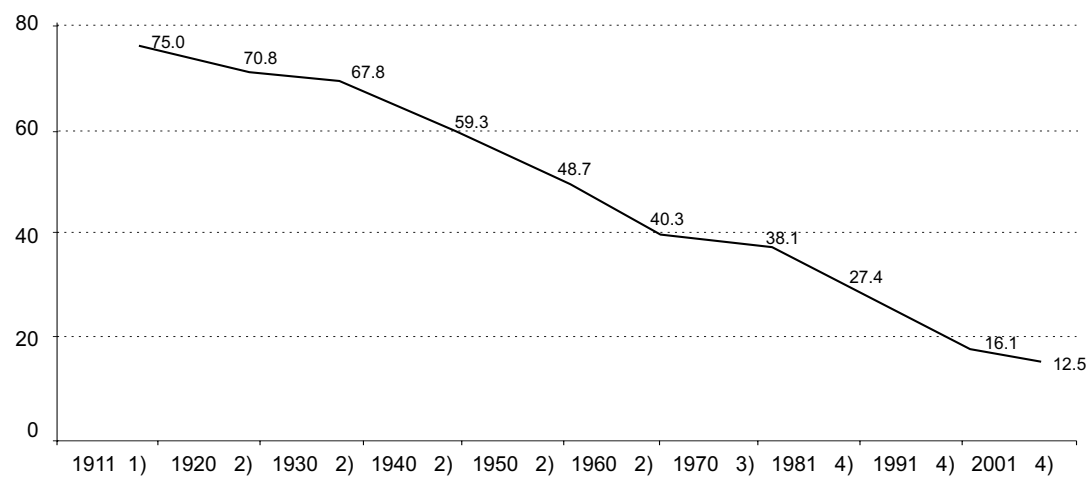

Figure 5.1 Illiterate or totally uneducated population, Portugal (\%)

Sources: 1) Abreu and Roldão (1989); 2) Carreira (1996); 3) Barreto (1996); 4) 1981, 1991 and 2001 census.

policies (particularly its compulsory nature). There was resistance on the part of some strata of the population who seemed to be suspicious of education or, as Augusto Santos Silva put it, "a temperate, prudent investment" (Silva, 2002: 177) and for whom the management of resources and the preparation of future strategies for their younger members was done without school playing an important role.

An example of this slow movement is the size of the illiterate population in Portugal. The descent from $75 \%$ in 1911 to $12.5 \%$ in the 2001 census shows that we are managing today to meet targets for generalisation of basic schooling set in 1836 (reasserted in 1911 and 1964 and at other times) and achieved by many European countries by the early $20^{\text {th }}$ century. This was in spite of successive calls for reform, met or not in legislation or mere projects, which helped to create the myth of educational reform as the panacea for all the country's education problems.

However, the empirical information tells us that these reforms do not seem to have had a decisive impact on the fall in the number of illiterates, not even changes in political regime, as illiteracy continued to drop during the Estado Novo, which for a long time openly disapproved of the idea of schooling for all (Mónica, 1977). There are differing opinions as to the causes of this progress. Some see in it an expression of the particularities of the transition of Portuguese society from the old regime to modernity, marked by an early definition of national borders and a language common to the whole population, meaning that less importance was attributed to school as a tool for building a nation-state, particularly in its role as a cultural unifier (Reis, 1993). Others are of a different view, considering that the question was always a political one and regarding keeping the population in ignorance as a condition for 


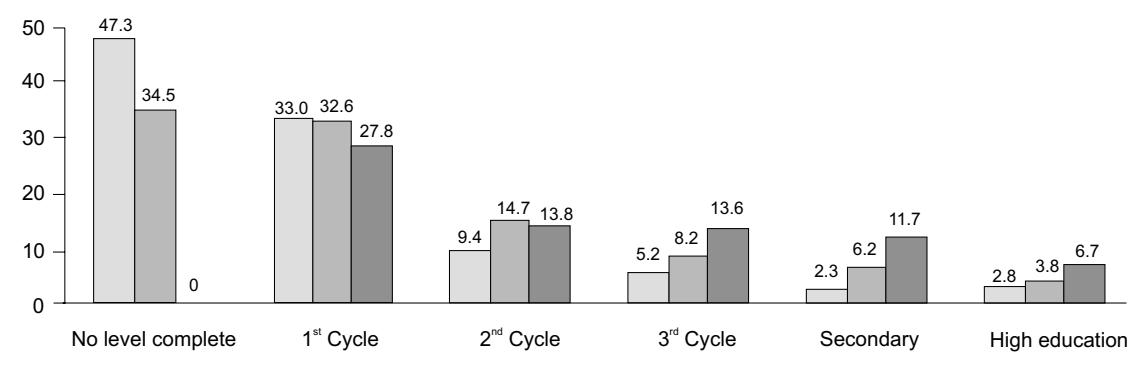

Figure 5.2 Resident population by completed level of schooling, Portugal (\%)

Source: 1981, 1991 and 2001 census.

remaining in power (Cabral, 2002). As we have already said (Sebastião, 1998) this development in fact represents a combination of the inability of the political elites to implement education policies and a significant disregard on the part of society for school and the skills it provides. This disregard has persisted over time and extends to other aspects such as vocational training or more broadly to the role of lifelong education as a central aspect of managing professional or personal projects and trajectories. However, in the last decade, there seems to have been a turn in the trend, although it is too early to say whether it is definitive. One of the indicators of this possible reversal is some change in the priorities of education policies, under pressure from the change in women's social situation resulting from their progressive integration into the job market. The definitive affirmation of the importance of general pre-school education, attempts to reintroduce adult education and the certification of competences are indicators of this change. ${ }^{2}$

The fact that compulsory schooling has been successively extended from four to nine years and the increase in demand for schooling have resulted in a fall in the percentage of the population with only primary schooling from $33 \%$ in 1981 to $27.8 \%$ in $2001.3 / 4$

However, if we combine this level of schooling with the other levels making up compulsory education ( $2^{\text {nd }}$ and $3^{\text {rd }}$ cycles) we find a gradual increase in percentage from 1981 to 1991 (34.3\% and 37.1\%, respectively) and a reduction in the last for the 2001 census (35.5\%). This reduction is essentially due to

2 But we can also find a progressive drop in available evening courses in secondary and higher education or a deceleration in the reduction in the number of illiterates from 1991 to 2001 . 


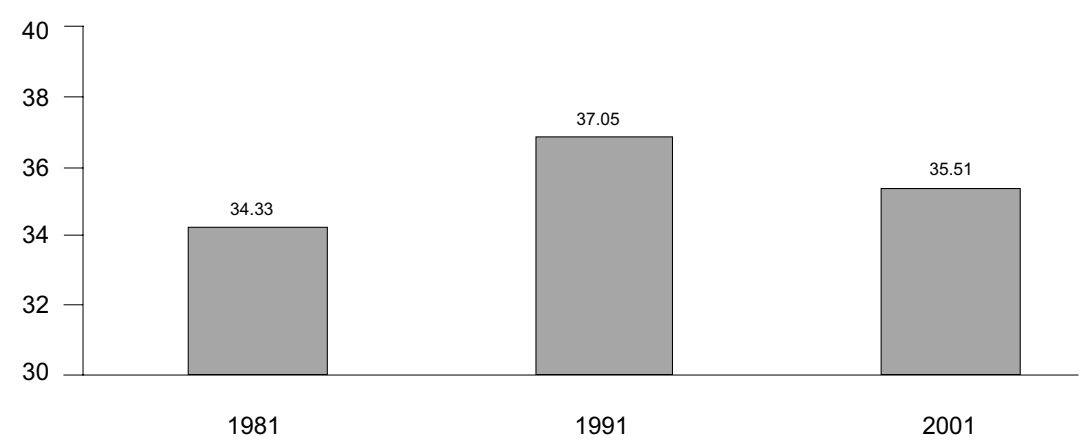

Figure 5.3 Population with compulsory schooling, Portugal (\%)

Note: (1) Includes students who have completed the $1^{\text {st }}, 2^{\text {nd }}$ and $3^{\text {rd }}$ cycles.

Source: 1981, 1991 and 2001 census.

a rise in the percentage of people completing secondary education (going from $2.3 \%$ in 1981 to $11.7 \%$ in 2001) and higher education (from $2.8 \%$ in the 81 census to $6.7 \%$ in 2001) and to the demographic decrease.

In view of the central aim of this analysis, which is to understand the forms of democratisation of education in Portugal, taking ages 10 to 14 as a reference, we point to the ideal age for completing each cycle of education. A student aged 12 who has never failed a year should have completed the $2^{\text {nd }}$ cycle and one aged 14 who has never failed a year should have completed the $3^{\text {rd }}$ cycle. All the others of these ages attending lower levels of education have a history of repeated years and are "outside the normal age" for attending that cycle. Looking at the $2^{\text {nd }} c y c l e$, we find that, from 1981 to 2001 there was a gradual fall in the number of students outside the normal age. Ten-year-old pupils still attending the $1^{\text {st }}$ cycle went from $6.5 \%$ in the 81 census to $4.8 \%$ in 1991 and $4.3 \%$ in 2001 . Residents aged 11 in exactly the same situation went from $3.6 \%$ in 1981 to $2.2 \%$ in 1991 and $1.5 \%$ in 2001 . The percentage of students within the normal age for attending the $2^{\text {nd }}$ cycle has been increasing. Those aged 10 went from $11.2 \%$ in 81 to $21.4 \%$ in 2001 and those aged 11 from $25.8 \%$ to $32 \%$.

3 The levels of education in compulsory schooling are increasingly less significant to the search for or performance of any kind of job.

4 We draw attention to the fact that the percentages in this graph refer to completed levels of schooling. In other words, they include residents who have reached the level, have not completed the next level but are or were attending it. E.g. the percentage of residents with the $1^{\text {st }}$ cycle includes residents who have completed this level, those who have not completed the $2^{\text {nd }}$ cycle and those who are or were attending the $2^{\text {nd }}$ cycle. 


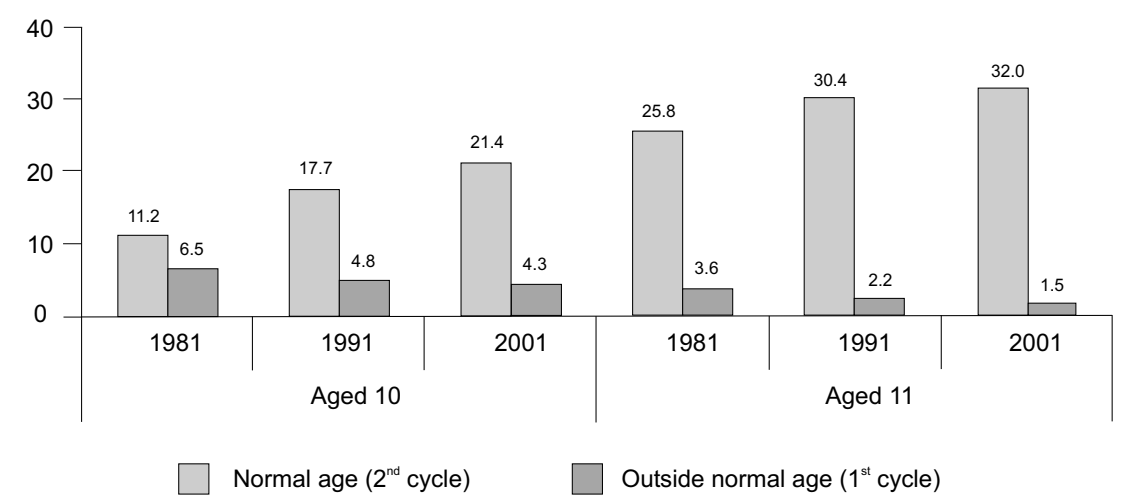

Figure 5.4 Deviation from normal age for attending $2^{\text {nd }}$ cycle, by age, Portugal (\%)

Source: 1981, 1991 and 2001 census.

With regard this level of education, Azevedo (2002) used the age of 13 as a reference between 1985/86 and 1997/98 and found a deviation of 30\%, which, according to him, meant that one in every four children in a particular school year was not of the "ideal" age.

We find exactly the same trend in the $3^{\text {rd }}$ cycle, which is the one with the most accumulated deviation. This is associated not only with failure itself at this level of education, but also the fact that it is the one where the situations of students who have failed in previous cycles are counted. The percentage of residents aged between 12 and 14 outside the normal age for attending this cycle has been going down. However, if we look at each age, we find that the percentage of students outside the normal age is higher among the 12-year-olds than the others. This can be explained by the fact that some of them were born in the second half of the year in which they started school and are therefore still 12 years old in the $2^{\text {nd }}$ cycle. In any case, the deviation has been decreasing. These students represented $17.9 \%$ in 1981, 13.9\% in 1991 and $11.2 \%$ in 2001 . As we have said, the other ages show lower percentages and also steeper decreases. The percentage for 13-year-old residents in 1981 was $12.8 \%$, in 1991 it was $8.5 \%$ and 2001 it was $5.7 \%$. For 14-year-olds the percentages were $7.8 \%, 5.5 \%$ and $3.6 \%$ in 1981, 1991 and 2001, respectively.

Azevedo (2002) conducted the same type of study for secondary and higher education and said that the deviations were much higher and the improvements slower. Only $60 \%$ of students attending secondary education and $54 \%$ in higher education were of the "ideal age". He said that the deviation rates at these levels were due to the accumulation of delays in previous cycles and higher incidence of failures in these two segments of the Portuguese education system. 


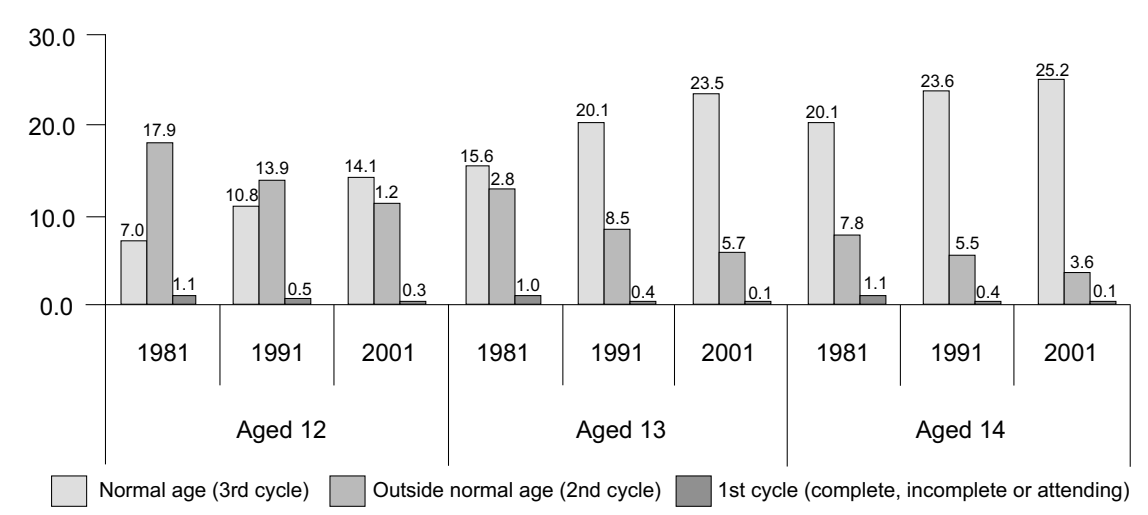

Figure 5.5 Deviation from normal age for attending $3^{\text {rd }}$ cycle by age, Portugal (\%)

Source: 1981, 1991 and 2001 census.

Other studies confirm these results and help us understand them. In the part of the PISA study that assessed literacy in the three areas of knowledge considered, the students' results in Portugal were lower than those for the countries in the "OECD area". While in Portugal only $48 \%$ of the students were able to successfully complete tasks (levels 3,4 and 5), the average in the OECD area was $60 \%$. Portugal ranked $26^{\text {th }}$.

According to the project, these results are interpreted by the reasons for students' success or failure and their paths and then they are compared. The main results show that, regarding personal skills and dispositions, the main contributions to success are hard work and perseverance, study strategies, a feeling of belonging to the school and motivation to study to achieve a good future. The most important external factors are the family's structural and educational resources (encyclopaedias, dictionaries, a place to study, etc.), its cultural assets (novels, literature, poetry, etc) and the parents' presence and interest in helping the student to understand the different subjects, be they cultural, social, school, etc. The factors that most influence the performance of students and consequently their schools are related to the social and monetary status of the students' families and of all the players involved in their daily lives, which reinforces the idea that results are associated with social, economic and cultural opportunities.

The study of school failure began in the late 1970s and has grown progressively in importance and become more central to the debate on the democratisation of education. There was a growing theory that it was not enough to guarantee equal access to school for there to be more equal opportunities. This realisation resulted in a significant number of debates and publications (generically on "failure at school"), giving rise in the political field to the 
Table 5.1 Students in TEIP after schools joining the Programme, in mainland Portugal(\%)

\begin{tabular}{lccc}
\hline & Passed & Kept down & Dropped out \\
\hline $1996 / 97$ & 72.7 & 16.0 & 2.5 \\
$1997 / 98$ & 76.9 & 15.5 & 3.4 \\
$1998 / 99$ & 80.8 & 13.4 & 2.5 \\
$1999 / 00$ & 84.4 & 13.2 & 2.2 \\
\hline
\end{tabular}

Source: ME - DEB - TEIP summary report 1999/00.

launch of measures and programmes. In the late 1980s, programmes focusing on educational achievement, such as the PIPSE, or the PEPT, which was designed to prevent students dropping out, constituted the first generation of measures that later evolved, after their limited impact became clear, into new measures concentrating more on supporting individual schools' initiatives. Alternative curriculum "programmes" and priority educational areas (TEIP), supported studies, etc were launched.

It is not possible to analyse the effectiveness of all the measures due to a shortage of data, but the available information, such as that from the TEIP, shows that their efficacy was relative.

Where higher education is concerned, there are more and more students attending this level, although we are far from reaching high rates. ${ }^{5}$ This growth may be related in general to the massification of secondary education and also to a demand for university education. One of the main characteristics of this growth is its rapid feminisation. According to Sedas Nunes (1968), there was already an increase in the percentage of women at university in the 1960s and the feminisation rate in the 1966/67 academic year was $41.5 \%$. He felt that this rate should be regarded as a result of several factors - the strict socio-economic "selectivity" of student recruitment, an accentuated trend towards the generalisation of higher education among women in more restricted social strata and a strong inclination on the part of the female population to seek qualifications to allow them to enter higher education (Nunes, 1968: 336). In fact this, this feminisation has made itself felt more and more and, according to Mauritti (2003), women account for $58.4 \%$ of all state university students surveyed and $67.2 \%$ of those in private higher education.

5 The 2001 census shows that there are still more illiterates than graduates in Portugal, which is an exact measure of the delay in the expansion in higher education and questions theories that there are too many graduates. 


\section{The mark of regional asymmetries}

The impulse given to pre-school education has brought greater social and school integration for the children attending it, which is a condition mentioned by several studies as essential to achieving higher percentages of passes in the long run. Regional asymmetries at this level of education help us to understand some of the effects of education policies based on abstract egalitarian criteria with no actual concern for trying to reduce real inequalities.

Where pre-school education is concerned, we find a sharp increase in coverage of the child population from a situation in which it was practically non-existent in the 1950 s and 60 s to $32.1 \%$ of national coverage in $1984 / 85$ and close to $50 \%$ in the mid-1990s. This progression is due to a combination of several factors - significant changes in family structure, growth as of the 1950s and 60 s in the number of working women, mostly full time, resulting in new forms of child care, the implementation in the late 1970s, early 1980s of policies protecting working women and expansion of childhood protection policies in the late 1980s and the 1990s. The state thereby took a much more interventional role in child socialisation through its own or partner institutions. Together, these factors brought substantial changes in family relations, forms of child care and even the relationship with work (Torres and Silva, 1998; Torres et al., 2004; Wall, São José and Correia, 2001, 2002a, 2002b, 2003 and Correia 2005), which converged as of the mid-1990s to high investment in pre-school education, which rapidly increased its population.

Growth was particularly significant, which shows that at least a substantial part of the expansion of the education system to new populations depends largely on active, lasting, financially sustainable public policies.

According to Joaquim Azevedo, in spite of this growth, the difference in pre-school coverage between regions increased in the 1990s, which he finds at least paradoxical, as the system was expanding. "While in 1991, there 37 percentage points between the district with highest attendance (Guarda) and that with the lowest (Porto), in 1999 there was a difference of 58 percentage points between Baixo Alentejo and Alentejo Litoral (the highest rate) and Tâmega (the lowest)" (Azevedo, 2002: 78). He feels that these asymmetries indicate a lack of specific policies for each region, suggest changes in the form of investment in pre-school education and draw attention to the need to cross-reference the characteristics of each region, such as rurality and illiteracy, with families' needs for social and economic insertion and labour feminisation rates. ${ }^{6}$ We might add to these factors,

6 Indeed, if we compare the attendance rate of four-year-olds at pre-school in Portugal with other EU countries, we find that while Portugal has a rate of $70 \%$ (with all the regional asymmetries), in the EU, with the exception of Greece with $56 \%$, the figures are all higher: Germany: 81\%, Belgium, 100\%, Denmark, 80\%, Spain, 99\%, France, 100\%, Netherlands 99\%, Italy, 93\%, Luxembourg, 100\%, UK, 94\% and Austria 72\% (Azevedo, 2002). 


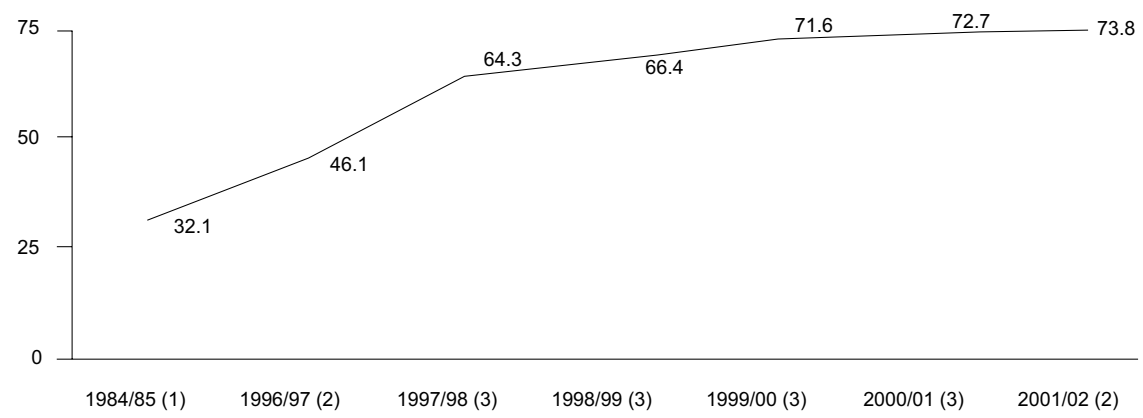

Figure 5.6 Pre-school rate in mainland Portugal (1984-2002) (\%)

Sources: 1) Bairrão et al. (1990); 2) DAPP, Taxas de cobertura de pré-escolarização (Estatísticas Preliminares); 3) DAPP, Ano escolar (Estatísticas Preliminares).

the importance of knowing regional demographic dynamics, the characteristics of the job market and cultural diversity. Regional disparities mean that in the regions with fewer resources for pre-school education, primary school is the first experience of formal socialisation by an institution with different values from that of the family and of structured contact with universal cultural elements. This is another indicator of regional educational disadvantages, as it is the regions with the highest pre-school rates that have the most goods and services and the highest percentages of secondary and higher education.

This type of regional asymmetry (expressing differing opportunities in access to education) is more clearly expressed in the schooling rates of the Portuguese population and their distribution in the country's different regions. Here, if there are differences between the different regions, they are shown more clearly by comparing the Lisboa e Vale do Tejo region with the rest of the country. ${ }^{7}$

The school qualification structure in the Lisboa e Vale do Tejo region (RLVT) stands out from all the others with its higher levels of schooling (secondary, further and higher). In the region, $21.5 \%$ of the resident population is in secondary education, ${ }^{8} 1.3 \%$ in further education and $16.3 \%$ in higher education. It is, however, necessary to take into consideration that data on the

7 The level of instruction achieved corresponds to the INE definition: highest complete or incomplete level of education achieved by subject

8 In spite of these clearly favourable figures at national level for RLVT, they are pretty low if we compare them to France, as there the target is for $80 \%$ of young people to complete secondary education. 


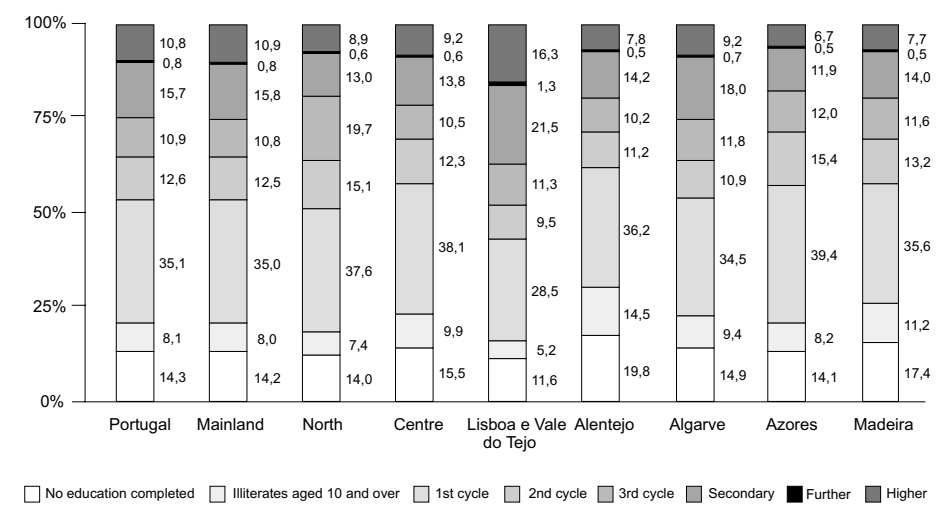

Figure 5.7 Resident population by geographical area and by level of education, Portugal (\%)

Source: 2001 census, table 1.03, page 3 .

resident population, may be slightly biased by the effect on internal migration by students from other regions to study in the capital and by the attraction of qualified workers seeking better job opportunities. In any case, the capital's force of attraction is a factor to be taken into account in itself, as it certainly increases the asymmetries. There is also considerable heterogeneousness within the Lisbon region, where we find overqualified areas next to under-schooled ones. At the other extreme, we find the Azores, which have 11. $9 \%$ of students in secondary, $0.5 \%$ in further and $6.7 \%$ in higher education.

Where the lowest qualification levels are concerned ( $1^{\text {st }}$ and $2^{\text {nd }}$ cycles $)$ the situation is essentially the reverse. With the exception of Lisbon, the largest group in all the regions consists of those that have only completed the $1^{\text {st }}$ cycle. The highest figures are $39.4 \%$ in Madeira and $38.1 \%$ in the centre, although none of the other regions has fewer than $35 \%$ with this level of education.

The Alentejo region and the Madeira Archipelago are those with the highest number of illiterates aged 10 and over or who have completed no level of education (illiterates over $10-14.5 \%$ in Alentejo and 11.2\% in Madeira and residents who have not completed any level of education $19.8 \%$ in Alentejo and $17.4 \%$ in Madeira).

An analysis of these data shows that the distribution of "school education" in the country's different regions is very different, which has cumulative effects on the educational opportunities of the younger generations. While we cannot talk of mechanical reproduction of levels of qualification between generations, as the younger ones tend to be more qualified than the older ones, it is also true that contexts in which educational and cultural resources are scarce help perpetuate low levels of qualification. This theory has been empirically confirmed by research and the sparse available statistics. 
The results of the PISA study also show considerable inequalities between the country's different regions, where students from Lisboa e Vale do Tejo are clearly ahead. They have higher averages than students in the rest of the country and sometimes even reach higher levels than the averages in the "OECD group" countries, ${ }^{9}$ though practically the opposite is the case for the rest of the country (except the northern region). The study also shows that the differences are, however, greater between students than between schools or regions, which draws attention to the inequalities between students, smaller in Lisboa e Vale do Tejo and the north but greater in the other regions.

The inequalities between regions resulting from different allocation of school resources around the country have the effect of increasing inequalities in access to education, thereby deepening social and cultural inequalities. Demographic changes (migration, aging) have radically altered the panorama in the municipalities outside the influence of the large metropolitan areas, which has led to profound restructuring of the school network, which normally concentrates students in schools in the municipal capitals (or even of groups of municipalities, as in northern Alentejo). The need for this readjustment has a considerable impact on the efforts made by children, families and local authorities and is reflected by long distance from the family, many hours of travel to school and high costs. Another factor that has contributed to these continuing asymmetries is the human resource policy of the Ministry of Education, which is based on centralisation and permanent instability of the teaching staff, which particularly penalises inland regions and those far from large cities (Benavente et al., 1994).

Starting with very different theoretic assumptions and empirical date Valadares Tavares reaches partially similar conclusions. On the basis of the results per municipality in $12^{\text {th }}$ grade exams he finds that there are strong regional asymmetries and that they show no tendency towards decreasing (Tavares, Graça and Tavares, 2002). The same conclusion had, indeed, already been reached (Ferrão and Neves, 1992), although on the basis of official ME indicators. In an analysis of secondary education, Azevedo (2002) used DES/ME data for 1997-2001 and found that the average final marks in secondary education mathematics varied from region to region. The disparities between regions were accentuated in terms of failures. He chose a mark of 6.9 out of 20 as a cut-off point and found that there were districts whose schools were unable to achieve more than this mark or did so very little. This was the case of the districts of Beja (12 schools), Bragança (14), Évora (12), Viana do Castelo (18), Azores (17) and Madeira (13). It was in the Aveiro, Braga, Coimbra, Lisbon and Oporto districts that around $40 \%$ of secondary schools had results above that mark.

9 The figures allow us, once again, to reflect on the introduction of education policies aimed specifically at each region and taking the social, economic and cultural characteristics of the target population into consideration. 
Other figures, like those on dropouts, show how these asymmetries have been perpetuated, with no significant trend towards improvement (Ferrão and Neves, 1992; Ferrão and Honório (ed.), 2000).

As Arroteia pointed out in 1991, these regional inequalities are often associated with other inequalities of a demographic, social, political or economic nature. This shows the inability of most of these regions to attract private investment or influence the distribution of public funds required to reverse the migratory flows to the big cities (Arroteia, 1991).

Regional asymmetries are one of the most discriminatory facets of the Portuguese education system, as they highlight a considerable number of inequalities in certain regions, thereby increasing the disadvantages of people with less schooling, be they children of rural workers or unqualified labourers. Social inequalities are compounded by difficult access to culture or even access to school itself, thereby contributing to the reproduction of low qualifications.

\section{The development of social inequalities in relation to education}

We will now analyse the democratisation of education from a more restricted point of view, focusing on the development of social inequalities in relation to education. We regard democratisation as the weakening of the causal relationship between students' social origin and their school results. Although it is clear today that social strata are faced with different shares of inequality, the social inequalities in relation to education indicator is still today one of those that best explain the changes in the education system's ability to fulfil the goal of providing the whole population with access to a common framework of cultural assets.

Democratisation in this sense faces considerable social ambiguity resulting from the contradiction between the desire for equality of the different participants in the education process and the desire (and also need and imposition) for differentiation. For example, families want equality but they also want "the best for their children". Political decision-makers pass egalitarian legislation but also divide resources unequally between regions and between schools. Teachers treat all students equally, even though they know that this favours the more advantaged among them.

One particularity marks research into social inequalities in relation to education and that is the scarcity of available statistics, which has lasted over the last few decades. We will therefore use dispersed information (sometimes hard to compare) produced over the years by research limited to some schools as a reference to compare with other recent data to identify any trends. Because of this situation, we had to extend the period studied, as there are data on basic and secondary education from the mid-1970s to the early 1980s and only one study for the 2000s. For higher education, we 
found research in the late 1960s, after that only in the late 1980s and then much more in the late 1990s.

In the second half of the 1970s there were several studies on the relationship between social origin, educational achievement and selective orientation in primary and secondary education, with special focus on Ângelo (1975), Grácio and Miranda (1977), Cruzeiro and Antunes, (1977 and 1978), Miranda (1978), and then Benavente and Correia (1981). These studies addressed two issues relevant regarding social inequalities in education at the time - inequality in educational achievement based on social origin and post-primary vocational orientation, whose filters at the end of primary education made a socially selective division into high schools and technical schools.

Where primary education is concerned, the empirical finding of the existence of a causal relationship between social origins and school results was made by research conducted by Sacuntala de Miranda and Sérgio Grácio on two different occasions (1977 - pilot study — and 1978). Considering only the results of the 1978 study, which was conducted in the municipality of Oeiras, the authors found a strong correlation between repeating a year and social origin and marked inequalities. They divided social positions into three categories ${ }^{10}$ and found repeating the year was accumulated in category C (68. $2 \%$ ) against only $6.8 \%$ in category $A$ and $16.9 \%$ in C. There was a high concentration of repeaters in category $\mathrm{C}$ compared to representativity in the sample, while the situation was exactly the opposite in the other two categories. This accumulation in one social category was combined with early repeating and strong polarisation of schools' social composition. Students from category C started school later, were concentrated in higher percentages in schools far from the coastal areas of the municipality and failed earlier and more often.

The study Obstacles to Educational Achievement in Primary School (Benavente and Correia, 1981) also confirmed this and opened new research paths from a psycho-sociological and pedagogical point of view. It also found high over-representation of pupils from lower social strata in the group whose school career was marked by failure and sought to understand the relationship between these failures and teachers' and parents' practices and attitudes.

Focusing his analysis on a population in more advanced schooling, in a study conducted in Évora in 1975, ${ }^{11}$ Ângelo showed a strong association between the type of education attended and the students' social origin. Of students attending technical school, $75.5 \%$ belonged to socioeconomic categories I and II ${ }^{12}$ against $52.2 \%$ in high school, while in categories III, IV and V13

10 Category A: senior managers and the professions, category B: shop-owners, bank and office employees, middle managers, category C: manual labourers, factory and construction workers, shop assistants 
only $24.5 \%$ were attending technical school (with no-one from category V) against $57.8 \%$ at high school. ${ }^{14}$ There were two associated effects with regard to educational achievement, as not only was the overall level lower in technical school (39.6\% of students with Average and only $2.6 \%$ with Good) but the school effect was also clearly making itself felt, as students in the lowest categories failed more at technical school, while the educational achievement of students from the same social categories at high school was not far from that of the higher categories (in particular at the highest level of achievement). The number of failures also reinforced this image, as the students who never failed at high school $(68 \%)$ contrasted clearly with the situation at technical school, where only $33 \%$ of the students had never failed. Among those who had failed, at high school the author found a group that had only failed once $(23 \%)$ and another smaller one that had failed two or more times $(9 \%)$. The situation at technical school was practically the opposite, with $39 \%$ of students who had only failed once and a very substantial group of students who had failed two or more times $(28 \%)$. In other words, the high school students belonged to higher social classes, came from families with more schooling and failed less (with only occasional failures).

Social selectivity was also expressed in the association between social origin, type of education and educational achievement, clearly showing the explicitly selective nature of the education system at the time. The results of a similar study (Cruzeiro and Antunes, 1978) later confirmed these conclusions for a group of municipalities in northern Lisbon.

The picture that we get from reviewing this research is one of high social selectivity and a clear reproductive role of school. It is important to point out that the Portugal in which these data were collected only partially coincides with the country today, as profound political, economic, social and cultural ${ }^{15}$

11 This interesting study was the result of a questionnaire given to high school and technical school students in the first year of secondary education (former 3rd year of high school, now $7^{\text {th }}$ year of schooling). The author did not feel that the high failure and dropout rates at the time and the fact that the students were beyond compulsory schooling influenced the results, which would distort their social composition even more than today.

12 Category I was rural, industrial and domestic workers, lone craftsmen and unqualified workers in services. Category II was other ranks in the armed forces, small farmers, drivers and retail employees. For a more detailed description see Ângelo, 1975: 585.

13 The classification here is not so clear, although it seems to express hierarchies of prestige at the time, for example placing secondary school teachers, officers in the armed forces, company directors and the professions in category $\mathrm{V}$ and retailers and industry owners in category IV. Category III covers intermediate-level office workers and civil servants, foremen, bank employees, primary-school teachers, farmers and managers.

14 This disparity in social composition was the main justification for the abolition of technical schools and high school and their unification in secondary education, although it was also the result of a trend in the more industrialised countries since the 1960s. See Viegas, José M. L. and Costa, António F., 1998 and Barreto, 2000. 
changes have deeply altered Portuguese society. The expansion of compulsory schooling makes it pointless to make a term-by-term comparison of the different levels of schooling, while changes in the class structure impose similar caution.

In recent research (Sebastião and Correia, 2005) at a number of schools in northern Lisbon, we found that, even so, these changes confirmed some of the previous conclusions, although with alterations in selective mechanisms and social visibility. We focused on students aged 14 at four $2^{\text {nd }}$ and $3^{\text {rd }}$ cycle schools that shared an urban area and sought to understand their paths through compulsory schooling and some of the relevant dimensions in the structuring of these paths.

One of the first dimensions identified had to do with the relationship between urban structuring and the schooling process. Lisbon's northward expansion has taken place at the expense of areas previously occupied by large, unused estates were awaiting action. They had once been old boundary areas where shanty towns flourished, but were now much more upmarket, and housing complexes designed for social segments with high purchasing power had been built there. However, at the same time, social housing had also been constructed on city council land, thereby creating a neighbourhood of substantial social contrasts, which was reflected in the social composition of schools. We were able to find two schools with large percentages of students from the higher social classes (more than 50\% EDL and PTE ${ }^{16}$ and no students from working-class families, and another two schools where these strata (EDL and PTE) represented less than $10 \%$ but had high percentages of administrative employees and salaried workers with more than one activity $(60 \%$ and $70 \%$ respectively). There were very few blue-collar workers even in working-class areas, which shows the need to take changes in socioeconomic structure into account when analysing data and selecting the pertinent social categories. ${ }^{17}$ This spatial distribution of the population is clearly related to the educational qualifications of the families of the students at the different schools. The first two had a high percentage of university graduates and the other two a high number of illiterates and people who had not completed any level of education (no graduates).

This situation reproduced some of the conclusions reached by Ângelo (1975) and Grácio and Miranda (1977). In the first case, students at technical school came mainly from the city of Évora (mostly less well-off families)

16 We have used the ACM (Almeida, Costa, Machado) typology here. For a detailed analysis see Machado et al., 2003; Almeida et al., 2003; Costa, 1999. They define seven categories: EDL - (entrepreneurs, top management and the professions); PTE - (executives and specialised professions); TI - (independent workers); TIpl - (independent workers $>1$ activity); $\mathrm{EE}-$ (administrative employees); $\mathrm{O}-$ (blue collar workers); $\mathrm{AEpl}-$ (salaried workers1 activity). 
while those at high school (mostly more well-off families) came from the whole district. Those who were not so well-off depended for their education on opportunities in their immediate surroundings, while for the better-off ones, the fact that they had more material, cultural and symbolic resources meant that they could choose more qualified and prestigious schools and were not directly dependent on their immediate environment.

Miranda (1978) also found location-based social inequalities in the municipality of Oeiras, where students from richer families with higher levels of schooling were concentrated in the coastal area (a more prestigious place to live) while those from less well-to-do families with lower levels of schooling were in the inland part of the municipality, characterised by neighbourhoods with illegal housing or poor access and quality of construction. The city's socially structured areas produced the school populations, while also contributing to the reproduction of social inequalities. A significant part of the socialising goals of school as a meeting place for children and young people from different social and cultural backgrounds fell by the wayside, though they were essential in the social integration processes produced in schools.

The second dimension, which came in part from the first, was related to the so-called school effect. We found a high concentration of students with a history of failure associated with strong social polarisation at schools, in particular in more serious situations (two or more failures). This effect results, among other factors, from the administrative policy of dividing the country into education authorities and clearly shows how apparently neutral decisions have highly differentiating effects.

While we cannot talk here of explicit early selection processes like those shown in the above-mentioned studies (Ângelo, 1975; Grácio and Miranda, 1977), there are others that have similar effects, due to their less visible nature. We identified different strategies by which the social composition of school populations, already divided administratively, was reinforced. The transfer from one school to another of students who are from social housing estates or

17 Many of the studies conducted in the 1960s and 70s on social inequalities in access to education were based on bourgeoisie/blue-collar dichotomies, which resulted from the relative importance of both in the social structure, the former because of the associated power and latter because of its numbers. The changes in occupational structure resulting from the permanent alterations in production processes have reduced the relative weight of blue-collar workers (although in Portugal, according to the 2001 census, they have increased slightly, in clear contrast with the other European countries) while the different categories of employees have grown. The internal and numerical changes have imposed the need for a revision of the relative importance of blue-collar workers as a central category in the analysis of sociology of education. This question is even more important when, in recent research, blue-collar workers seemed to have been partially replaced in the dichotomy by a diffuse category whose name oscillates between "working classes" and "the excluded", without there being a better understanding of the mechanisms producing inequalities at school. 
Table 5.2 Educational careers of students by school, 2003/2004

\begin{tabular}{l|rr|rr|rr|rr}
\hline & \multicolumn{2}{|c|}{$\begin{array}{c}\text { Path 1 } \\
\text { (no fails) }\end{array}$} & \multicolumn{2}{c|}{$\begin{array}{c}\text { Path 2 } \\
\text { (failed once) }\end{array}$} & \multicolumn{2}{c|}{ Path 3 } & \multicolumn{2}{c}{ Total } \\
& $\mathrm{N}$ & $\%$ & $\mathrm{~N}$ & $\%$ & $\mathrm{~N}$ & $\%$ & Total & $\%$ \\
\hline School 1 & 82 & 82.0 & 11 & 11.0 & 7 & 7.0 & 100 & 100.0 \\
School 2 & 13 & 33.3 & 7 & 17.9 & 19 & 48.7 & 39 & 100.0 \\
School 3 & 37 & 41.1 & 20 & 22.2 & 33 & 36.7 & 90 & 100.0 \\
School 4 & 71 & 63.4 & 27 & 24.1 & 14 & 12.5 & 112 & 100.0 \\
Total & 203 & 59.5 & 65 & 19.1 & 73 & 21.4 & 341 & 100.0 \\
\hline
\end{tabular}

Source: Sebastião and Correia, 2005.

are repeating a year is a way of raising the school's overall success rates thereby improving its prestige and increasing demand from families, even outside its catchment area. This closing-in strategy is combined with strategies to avoid "bad schools" on the part of families with high educational and social ambitions, giving rise to significant inter-school mobility. They use addresses "borrowed" from family or friends to get a place at a school where their children will have a better chance of success.

Another aspect, which has been identified in other research, is also partly due to the social composition of schools. Students from higher social classes (EDL and PTE) fail more when attending schools mostly of lower classes (EE, AEpl, O) and the reverse is the case for the lower classes. When in a minority, as in Schools 1 and 4 of the study, students of lower social origins seem to achieve higher average results than those of the same classes when in a majority at school.

The combination of these factors (administrative division, closing of schools, family avoidance strategies, different educational achievement) results in schools like those we have been describing, reinforcing factors of success at some and success at others, ${ }^{18}$ and, under the cloak of a single education, helping maintain a structure of inequalities that is partly similar to that identified by Ângelo (1975) and Miranda and Grácio (1977) 30 years ago. Formal early orientation and selection mechanisms were abolished, first with the introduction of the preparatory cycle then with the unification

18 It is worth mentioning that the combination of these factors not only influences social composition social, but also has a cascade effect. For example, the demand for these schools by teachers is also affected by it, leading to high teacher stability at the so-called "good schools", which have a high social composition, high educational achievement, students with good outside educational support and low conflict levels with parents and students. For example, in our study, the overwhelming majority of the teachers at School 1 had tenure, as opposed to only $10 \%$ at School 3, though we had already identified this situation in a study on dropouts (Benavente et al., 1994). 
Table 5.3 Educational careers of students by social class, 2003/2004

\begin{tabular}{|c|c|c|c|c|c|c|c|c|}
\hline \multirow{2}{*}{ Class } & \multicolumn{2}{|c|}{$\begin{array}{l}\text { School path } 1 \\
\text { (no fails) }\end{array}$} & \multicolumn{2}{|c|}{$\begin{array}{l}\text { School path } 2 \\
\text { (failed once) }\end{array}$} & \multicolumn{2}{|c|}{$\begin{array}{c}\text { School path } 3 \\
\text { (failed twice or more) }\end{array}$} & \multicolumn{2}{|c|}{ Total } \\
\hline & $\mathrm{N}$ & $\%$ & $\mathrm{~N}$ & $\%$ & $\mathrm{~N}$ & $\%$ & $\mathrm{~N}$ & $\%$ \\
\hline EDL & 24 & 66.6 & 4 & 11.1 & 8 & 22.2 & 36 & 10.9 \\
\hline PTE & 100 & 85.4 & 11 & 9.4 & 6 & 5.1 & 117 & 35.6 \\
\hline $\mathrm{TI}$ & 0.0 & 0.0 & 1 & 50 & 1 & 50 & 2 & 0.6 \\
\hline TIpl & 2 & 50 & 1 & 25 & 1 & 25 & 4 & 1.2 \\
\hline EE & 35 & 44.8 & 20 & 25.6 & 23 & 29.5 & 78 & 23.7 \\
\hline 0 & 10 & 47.0 & 6 & 28.5 & 5 & 23.8 & 21 & 6.4 \\
\hline AEpl & 28 & 39.4 & 21 & 29.5 & 22 & 30.9 & 71 & 21.6 \\
\hline Total & 199 & 100 & 64 & 100 & 66 & 100 & 329 & 100 \\
\hline
\end{tabular}

Source: Sebastião and Correia, 2005.

of secondary education but, not unsurprisingly, the selection mechanisms throughout the school career have not disappeared. We say partly because, as there are no data or studies on these levels of education, it hard to clearly fathom whether we are looking at the democratisation of education or just the effects of the expansion of schooling, which just proportionally increased the number of representative of the different social classes at higher levels in the education system.

These studies show a metamorphosis in the selective filters resulting from their elimination at lower levels of the education system and the extension of compulsory schooling, thereby allowing for longer school careers. But at the same time, we now find more hidden selection mechanisms that are more diffuse in time (many of them from the education system itself) that, in spite of measures aimed at democratising access to higher levels, cause constraints that often become actual barriers to this progression. The social and school effects of these trends towards longer attendance by different social groups at different levels of the education system were clearly confirmed by a third group of studies analyzing the social composition of students in higher education.

These studies, which were conducted after the second half of the 1960s in a context of questioning democracy in higher education (Nunes, 1968; Machete, 1968), highlighted the existence of particularly restrictive school social recruitment mechanisms. This selectivity was clearly present in the figures given by Sedas Nunes. "In the social strata where higher socio-professional groups are concentrated, in 1963/64 there was one student for every seven families. In those with lower social groups, in the same year there was one student for every 1,191 families. " (Nunes, 1968: 388) If we look at the percentages, we find great disparities. While the "upper" and "upper middle" classes represented $42.3 \%$ and $41.1 \%$ of students in higher education, the figures for 
the "lower middle" and "lower" classes were $11.1 \%$ and $4.2 \%$, respectively. ${ }^{19}$ Rui Machete offers similar data when comparing data on Lisbon, Coimbra and Oporto universities (Machete, 1968).

With partly similar concerns, 20 years later, João Ferreira de Almeida, António Firmino da Costa and Fernando Luís Machado (1988; 1989; 1990) found that, although an overwhelming percentage of students attending ISCTE Lisbon, University Institute, degree courses had parents in the petit bourgeoisie of executive and specialised professionals, there was also a substantial number of students from social origins with fewer monetary, cultural, social, and educational resources (Machado et al., 2003). According to Maurit$\mathrm{ti}$, there is a higher influx into university of young people whose parents have completed no more than primary school, ${ }^{20}$ although this can be at least partially attributed to the effect of massification. ${ }^{21}$ However, the social profile of students' families of origin shows that, although access to higher education has changed considerably since the study by Sedas Nunes, it is still clearly marked by social inequalities. Around $62 \%$ of students are from the highest social categories (EDL and PTE) against 24\% from lower origins (EE, O, AEpl), which shows that university still makes a substantial contribution to the reproduction of social inequalities (Machado et al., 2003). The same study also showed that there had been progress in spite of this selective nature, as in 2001 the probability of a child of parents who were entrepreneurs, senior managers or members of the professions or executives and specialized professions going to university was eight times higher than for a child of blue-collar workers, while in 1981 the probability was 35 times higher.

In other words, access to higher education by the so-called less advantaged classes has grown when participation is viewed over the long run, though this participation is still restricted if we consider the relative weight of each stratum in the structure of social position. The democratisation of higher education is obviously linked to democratisation of other levels of education, where failure and dropout rates are still high and marked by their social tone.

\section{Closing remarks}

What kind of democratisation of the education system do we have in Portugal?

19 Author's terminology.

20 According to Mauritti (2003), the highest percentage of students are from families with no more than four years of schooling ( $28.8 \%$ of fathers and $31.6 \%$ of mothers) or with no schooling at all $(1.9 \%$ and $2.5 \%$, respectively).

21 The class recruitment index (Machado et al., 2003) differentiates growth in a certain social category in higher education superior, which results from the mere extension of supply, a change in the relative weight of each of them in the whole student population. 
Today, it is clear that there are contradictory trends in the midst of that which we usually call the education system, some indicating greater openness and democratisation, others seeming to want a return to an elite schooling, which still exists to some extent. There are still great asymmetries visible in very different school paths and associated with social origin, place of residence or school attended, which shows that there is still a long way to go before all young people have material, cultural or social opportunities to develop their personalities and skills with a minimum of equality. It is particularly important to understand that most of these possibilities occur in successful compulsory schooling, which will entail significant changes from a formally egalitarian policy to a qualitative model that promotes open, multi-cultural socialisation processes based not only strictly school schemes but also on community development. Investing in education today is not just a question of putting a school and a group of teachers in a particular place; it is promoting networked cooperation between the different institutional and education agents in the community in order to promote its development. Differentiated education that has different paths leading to the same goal, which rejects a return to the selective, elitist schools from the time of high schools and technical schools, which can instil in its students the desire to study for many, fruitful years and an ability not only to learn independently but also to cooperate in the development of collective projects, is the challenge facing basic schooling in Portugal.

\section{References}

Abreu, Isaura, and Maria do Céu Roldão (1989), “A evolução da esolaridade obrigatória em Portugal, nos últimos vinte anos", in Eurico Lemos Pires, O Ensino Básico em Portugal, Oporto, Edições ASA.

Almeida, João Ferreira de, António Firmino da Costa, and Fernando Luís Machado (1988), “Famílias, estudantes e universidade: painéis de observação sociográfica", Sociologia, Problemas e Práticas, 4, pp. 11-44

Almeida, João Ferreira de, et al. (2003), Diversidade na Universidade. Um inquérito aos Estudantes de Licenciatura, Oeiras, Portugal, Celta Editora.

Ângelo, Vitor (1975), “O ensino discriminatório: liceu e escola técnica”, Análise Social, XI (44), pp. 576-629.

Arroteia, Jorge Carvalho (1991), Desequilíbrios Demográficos no Sistema Educativo Português (Cadernos de Análise Sócio-Organizacional da Educação, 3), Aveiro, Portugal, Universidade de Aveiro.

Azevedo, Joaquim (2002), O fim de um ciclo? A Educação em Portugal no Início do Século $X X I$, Oporto, Edições ASA.

Bairrão, Joaquim, and others (199), Perfil Nacional dos Cuidados Prestados às Crianças com Idade Inferior a Seis Anos, Lisbon, Fundação Calouste Gulbenkian.

Barreto, António (ed.) (1996), A situação Social em Portugal, 1960-1995, Lisbon, ICS-UL. Barreto, António (ed.) (2000), A situação Social em Portugal, vol. II (1960-1999), Lisbon, ICS. 
Benavente, Ana (1976), A Escola na Sociedade de Classes. O Professor Primário e o Insucesso Escolar, Lisbon, Livros Horizonte.

Benavente, Ana, et al. (1994), Renunciar à Escola. O Abandono Escolar no Ensino Básico, Lisboa, Fim de Século.

Benavente, Ana (2001), “Portugal, 1995/2001: reflexões sobre democratização e qualidade na educação básica", Revista Ibero-Americana de Educação, vol. II (1960-1999), Lisbon, ICS.

Benavente, Ana, and M. A. P. Correia (1981), Obstáculos ao Insucesso na Escola Primária, Lisbon, Instituto de Estudos para o Desenvolvimento.

Bourdieu, Pierre, and Patrick Champagne (1992), "L'exclus de l'intérieur", Actes de la Recherche en Sciences Sociales, 91/92, pp. 71-75.

Cabral, Manuel Villaverde (2002), “Espaços e temporalidades sociais na educação em Portugal", in AA. VV., Espaços de Educação, Tempos de Formação, Lisbon, Gradiva.

Carreira, Medina (1996), As Políticas Sociais em Portugal, Lisbon, Gradiva.

Coleman, James S. (1990), "Inequality, sociology and moral philosophy”, in James S. Coleman, Equality and Achievement in Education, Boulder, Westview Press, pp. 31-54.

Correia, Sónia Vladimira (2005), Estratégia de Concialiação Trabalho. Vida Familiar em Famílias de Mães Sós, masters' degree thesis, Instituto de Ciências Sociais da Universidade de Lisboa, Lisbon (policopied).

Costa, António Firmino da (1990), Sociedade de Bairro, Oeiras, Portugal, Celta Editora.

Costa, António Firmino da, Fernando Luís Machado and João Ferreira de Almeida (1990), "Estudantes e amigos: trajectórias de classe e redes de sociabilidade", Análise Social, XXV (105-106), pp. 193-221.

Cruzeiro, Maria Eduarda, and Manuel Antunes (1977), “Ensino secundário: duas populações, duas escolas", Análise Social, XIII (49), pp. 147-210.

Cruzeiro, Maria Eduarda, and Manuel Antunes (1978), “Ensino secundário: duas populações, duas escolas", Análise Social, XIV (55), pp. 443-502.

Ferrão, João, and António Oliveira das Neves (1992), Caracterização Regional dos Factores de Abandono Escolar no 2.ํ e 3. ${ }^{\circ}$ Ciclo do Ensino Básico, Lisbon, Ministério da Educação/PEPT.

Ferrão, João, and F. Honório (eds.) (2000), Saída Prematura dos Sistema Educativo: Aspectos da Situação Causas e Perspectivas em Termos de Emprego e Formação, Lisbon, Observatório do Emprego e Formação profissional.

Grácio, Sérgio (1997), Dinâmicas de Escolarização e das oportunidades Individuais, Lisbon, Educa-Formação.

Grácio, Sérgio, and Sacuntala de Miranda (1977), “Insucesso escolar e origem social: resultados dum inquérito-piloto", Análise Social, XIII (51), pp. 721-726.

Instituto Nacional de Estatística (Statistics Portugal), Recenseamento Geral da População de 1981.

Instituto Nacional de Estatística (Statistics Portugal), Recenseamento Geral da População de 1991.

Instituto Nacional de Estatística (Statistics Portugal), Recenseamento Geral da População de 2001. 
Leridon, Henri (2000), “ Présentation”, Population, 1.

Machado, Fernando Luís, António Firmino da Costa, and João Ferreira de Almeida (1989), “Identidades e orientações dos estudantes: classes, convergências, especificidades", Revista Crítica de Ciências Sociais, 27-28, pp. 189-209

Machado, Fernando Luís et al. (2003), “Classes Sociais e estudantes universitários: origens, oportunidades e orientações", Revista Crítica de Ciências Sociais, 66.

Machete, Rui (1968), "A origem social dos estudantes portugueses", Análise Social, VI (20-21), pp. 213.

Mauritti, Rosário (2003), “Caracterização e origens sociais", in Diversidade na Universidade. Um Inquérito aos Estudantes de Licenciatura, Estudos sobre a Juventude, Lisbon, IPJ, pp. 13-30

Miranda, Sacuntala de (1978), “Insucesso escolar e origem social no ensino primário: resultados de um inquérito na zona escolar de Oeiras-Algés", Análise Social, XIV (55), pp. 609-726.

Mónica, Maria Filomena (1977), “Deve-se ensinar o povo a ler?": a questão do analfabetismo (1926-39)", Análise Social, XIII (50), pp. 321-353.

Perrenoud, Philippe (1986), “Das diferenças culturais às desigualdades escolares: a avaliação e a norma num ensaio indiferenciado", in Linda Allal, J. Cardinet e Philippe Perrenoud, A Avaliação Formativa num ensaio Diferenciado, Coimbra, Livraria Almedina, pp. 27-75.

Reis, Jaime (1993), “O analfabetismo em Portugal: uma interpretação”, Colóquio Educação e Sociedade, 2, pp. 13-40.

Sebastião, João (1998), “Os dilemas da escolaridade”, in José Manuel Leite Viegas and António Firmino da Costa (eds.), Portugal, Que Modernidade?, Oeiras, Portugal, Celta Editora.

Sebastião, João, and Sónia Vladimira Correia (2005), "A Geração de 90". Políticas de Educação Básica, Desigualdades Sociais e Trajectórias Escolares (policopied), Lisbon, CIES.

Sedas Nunes, Adérito (1968), “A população universitária portuguesa: uma análise preliminar", Análise Social, VI (22-23-24).

Silva, Augusto Santos (2002), "'Acesso' e 'sucesso': factos debates na democratização da educação em Portugal”, in Maria Manuel Vieira, Joaquim Pintassilgo and Benedita Melo, Democratização Escolar. Intenções e Apropriações, Lisbon, CIE/FCUL.

Tavares, Luís V., Pedro M. Graça, and M. aㅡ Mael V. Tavares (2002), Estudo SEDES. Assimetrias Regionais do Desempenho Educativo (policopied), Lisbon, Observatório de Prospectiva da Engenharia e da Tecnologia e Centro de Sistemas Urbanos e Regionais do IST.

Torres, Anália, and Francisco Vieira da Silva (1998), “Guarda das crianças e divisão do trabalho entre homens e mulheres", Sociologia, Problemas e Práticas, 27, pp. 9-65.

Torres, Anália et al. (2004), Homens e Mulheres entre Família e Trabalho, Lisbon, Comissão para a Igualdade no Trabalho e no Emprego.

Vallet, Louis André (2001), “La mesure des évolutions des inégalités socials et scolaires en longue peériode", in R. Boudon, N. Bullee and M. Cherkaoui, École et Societé. Les Paradoxes de la Democratie, Paris, PUF, pp. 187-206. 
Viegas, José Manuel Leite, and António Firmino da Costa (1998), Portugal, Que Modernidade?, Oeiras, Portugal, Celta Editora.

Wall, Karin, José São José, and Sónia Vladimira Correia (2002a), “Mães sós e cuidados às crianças", Análise Social, XXXVII (163), pp. 631-663.

Wall, Karin, José São José, and Sónia Vladimira Correia (2002b), Child Care Arrangements in Dual Career Families. Portugal (policopied), Lisbon, ICS.

Wall, Karin, José São José, and Sónia Vladimira Correia (2003), Child Care Arrangements in Migrant Families. Portugal (policopied), Lisbon, ICS. 


\title{
Immigration policies in Portugal
}

\author{
Rui Pena Pires and Filipa Pinho
}

\section{Migratory context}

Since the 1980s, immigration has ceased to be a minor component in Portuguese population movements. At the beginning of the $21^{\text {st }}$ century, the foreign population with residence permits and temporary presence permits amounted to approximately 400,000 people, thus representing around $4 \%$ of the total resident population. In the recent history of Portuguese immigration it is possible to distinguish three periods: immigration from Africa following decolonisation, the 1980s and 1990s, which were marked by the growth and diversification of migratory flows, and the period of new migrations from Eastern Europe and Brazil at the turn of the century. ${ }^{1}$

Since the 1980s, in line with the trend in Mediterranean Europe as a whole (Werth et al., 1991; Machado, 1997), immigration into Portugal has been developing at an accelerated pace. Between 1980 and 1999, the foreign population with Portuguese residence permits increased at an average annual rate of $6.5 \%$. In this period, a migratory system emerged that was essentially composed of flows of unskilled workers from the PALOP (Portuguese-speaking African countries) and flows of skilled professionals from the EU (and the USA, to a lesser extent). The slow establishment of a flow of Brazilian immigration, notably heterogeneous from a socio-occupational viewpoint, is also worth mentioning. At the end of the period, around 200, 000 foreigners were living in Portugal, of whom $28 \%$ were from the EU, $45 \%$ from the PALOP and $11 \%$ from Brazil.

At the end of the 1990s, references to the emergence and rapid growth of new immigration flows from Eastern Europe began to appear in the Portuguese press, in documents from the SEF (Foreigners and Borders Service) and

1 This paper develops and updates sections of chapter 3 of Pires (2003). 
Table 6.1 Foreign population resident in Portugal, 2004

\begin{tabular}{|c|c|c|c|}
\hline & $\begin{array}{c}\text { Residence } \\
\text { permit }\end{array}$ & $\begin{array}{c}\text { Temporary } \\
\text { presence permit }\end{array}$ & Total \\
\hline Total & 265,361 & 183,833 & 449,194 \\
\hline Europe & 83,859 & 101,106 & 184,965 \\
\hline EU-15 & 73,689 & 0 & 73,689 \\
\hline Germany & 13,128 & 0 & 13,128 \\
\hline Belgium & 2,658 & 0 & 2,658 \\
\hline Spain & 15,916 & 0 & 15,916 \\
\hline France & 9,312 & 0 & 9,312 \\
\hline Netherlands & 5,366 & 0 & 5,366 \\
\hline Italy & 4,592 & 0 & 4,592 \\
\hline United Kingdom & 18,005 & 0 & 18,005 \\
\hline Others Europe & 10,170 & 101,106 & 111,276 \\
\hline Belarus & 92 & 1,101 & 1,193 \\
\hline Bulgaria & 776 & 2,849 & 3,625 \\
\hline Russian Federation & 1,158 & 7,053 & 8,211 \\
\hline Moldova & 1,042 & 12,647 & 13,689 \\
\hline Romania & 1,211 & 10,944 & 12,155 \\
\hline Ukraine & 1,497 & 64,730 & 66,227 \\
\hline Africa & 123,093 & 29,808 & 152,901 \\
\hline PALOP & 116,055 & 24,475 & 140,530 \\
\hline Angola & 26,702 & 8,562 & 35,264 \\
\hline Cape Verde & 55,590 & 8,574 & 64,164 \\
\hline Guinea Bissau & 20,825 & 4,323 & 25,148 \\
\hline Mozambique & 5,010 & 461 & 5,471 \\
\hline São Tomé and Príncipe & 7,928 & 2,555 & 10,483 \\
\hline Others Africa & 7,038 & 5,333 & 12,371 \\
\hline Americas & 45,161 & 39,054 & 84,215 \\
\hline Canada & 1,863 & 30 & 1,893 \\
\hline USA & 7,998 & 63 & 8,061 \\
\hline Brazil & 28,956 & 37,951 & 66,907 \\
\hline Venezuela & 3,470 & 0 & 3,470 \\
\hline Others Americas & 2,874 & 1,010 & 3,884 \\
\hline Asia & 12,410 & 13,724 & 26,134 \\
\hline China & 5,309 & 3,909 & 9,218 \\
\hline India & 1,699 & 3,389 & 5,088 \\
\hline Pakistan & 1,358 & 2,854 & 4,212 \\
\hline Others Asia & 4,044 & 3,572 & 7,616 \\
\hline Oceania & 553 & 19 & 572 \\
\hline Stateless & 273 & 39 & 312 \\
\hline Unknown & 12 & 83 & 95 \\
\hline
\end{tabular}

NB: the data for residence permits is provisional.

Source: SEF (Foreigners and Borders Service).

in initiatives by non-governmental organisations. The actual extent of these flows, however, would only be visible when the new rule for temporary presence permit came into effect. This was established by Decree-Law no. 4/2001, which is analyzed below and, in practice, included the granting, in Portugal, 
of a work visa to foreign citizens living illegally in Portugal, provided when they had a work contract with an employer. The massive legalisation carried out with the granting of the new status also revealed the exponential growth in illegal immigration from Brazil.

With these new flows, a sudden rise in the foreign population in Portugal can be observed at the end of the 1990s and beginning of the present decade: on 31 December 2002 there were over 400, 000 foreigners (about double the number in 2000) living legally in Portugal, that is, $4 \%$ of the total population of the country. About half had residence permits while the other half had temporary presence permits.

This growth and diversification in immigration from the end of the 1990s can be explained by a combination of external and internal factors. At the external level, prominence should be given to the pressure to emigrate in the migrants' countries of origin (in particular, Brazil and Eastern Europe) and the dynamics produced by European integration. It should be kept in mind that the new immigration from Eastern European countries is not only due to social disorganisation processes inherent in the political and economic transition affecting these countries, but also the accumulation, over years, of an unfulfilled migratory potential: "In retrospect, it is clear that the end of the Cold War was a watershed event in the history of global migration, ending a policy regime that had held world emigration rates at artificially low levels for more than 40 years" (Massey, 1999: 311). At the internal level, prominence should be given in particular to the changes on a socio-demographic and corporate plane. On the first of these two, a phase involving the progressive drying up of internal labour reserves was being experienced due to the resurgence of emigration, the rapid fall in the birthrate and its continuation at a low level (inhibiting replacement of the population), and the accelerated feminisation of the working population. On the corporate plane, there was the general spread of methods producing precarious wage relationships in different sectors, along with the spread of management practices based on the outsourcing of a company's non-core or non-permanent activities, and concentration processes like those involving large-format commercial activities. As a consequence, there was an expansion in the labour market segments that Piore (1979) and Portes (1999) qualify as belonging to the secondary sector. Their more precarious nature is linked to the non-continuous nature of the activity (particularly construction), informality in the employment relationship (particularly construction and cleaning) and, in general, eccentric and extended working hours, low pay and a diminished status - characteristics that make them unattractive locally. In those places, therefore, the demand for immigrant labour tends to be greater. ${ }^{2}$

The growth in immigration due to the growth in demand in these labour market sectors was reflected in the predominance of unskilled work-migration flows in terms of the occupations in the place of destination. Thus, the 
polarised model that had characterised the configuration of migrations to Portugal since the 1980s was altered, even if, ironically, with the immigration from Eastern Europe, there was an increase in the number of immigrants with educational qualifications above the national average.

Over these three periods it is possible to see the emergence of immigration policies that did not exist in the Portugal of the Estado Novo, with its closed doors. In the first period, these policies were cantered on the question of nationality; in the second, importance was given to the progressive rebalancing of policies to control migratory flows and policies to promote the integration of immigrants; and, finally, in the third period, there was a trend towards recentring policies on the question of immigration control.

\section{The nationality issues}

From the immigrant point of view, the changes to the nationality legislation following the 25 April Revolution established a more restrictive framework, discouraging settlement. The principle followed was to substitute the ius solis system in effect (dependent on place of birth) with a mixed system in which ius sanguinis (dependent on blood-ties) predominated.

This change commenced with decolonisation. Independence in the Portuguese ex-colonies presented the question of the maintenance or loss of Portuguese nationality for those resident or born there before independence. On 24 June 1975, with Decree-Law no. 308-A/75, the lawmakers chose to "establish the loss of Portuguese nationality as a basic principle" (Esteves et al., 1991: 132).

Since the introduction of the Civil Code in 1867, the legal regulations on nationality in Portugal had been based on the ius solis criterion. ${ }^{3}$ This was maintained (and improved) in the 1959 law on nationality (Law no. 2098/59) and meant that those who were born in the former colonies, before the time of independence, had the right to Portuguese nationality for their whole life.

Fearing the migratory effects of the political crisis (and the civil war, in the case of Angola) which marked the transition of the ex-colonies to independence,

2 This growth of secondary sector is consistent with Dornelas' analysis of the persistence in Portugal and other southern European countries of a "system of low labour standards" characterized by "a very high level of wage flexibility (...), very high percentages of workers on low salaries (...) and the highest levels of wage dispersion in the European Union" (Dornelas, 2001: 510-1).

3 Ius solis refers to systems in which the right to nationality is given to anyone who is born in the country; ius sanguinis refers to systems in which the right to nationality is given to all descendants of that country's nationals. In practice, these systems have the status of ideal types, since existing rules on nationality represent a combination of the two systems, though one of them predominates, in particular with regard to the granting of nationality to foreigners' children who are born in the country. See Weil (2001) for an international comparison of different rules on nationality. 
the state decided to prevent, selectively, the possibility of an influx of refugees. Selectively, as it was considered necessary to allow the resident white population in the ex-colonies the option to be repatriated, as the insecurity resulting from the crisis and civil war was increased by the fear of an inversion of colonial racial discrimination.

As they could not apply that selectivity on a racial basis, the Portuguese political authorities of the time resolved the dilemma by submitting the possible retention of nationality by those born and resident in the ex-colonies to the ius sanguinis criterion. After independence, essentially, the Portuguese born in Portugal (mainland or islands) or with forebears born in Portugal (mainland or islands) retained Portuguese nationality. ${ }^{4}$

This legislative measure had far-reaching effects on the subsequent history of immigration in Portugal, for three fundamental reasons: (i) it distinguished between repatriation from the ex-colonies and the immigration of foreigners with the same origin; (ii) it defined the legal and symbolic conditions (in the area of identity and belonging) for the integration of future immigrants, foreigners and their descendants into Portuguese society; and (iii) it contributed to the perception of immigration as a threat and chose a reduction in immigrant rights as a specific strategy to deal with that threat, in that it was (or was considered to be) an element that discouraged an increase in flows and, particularly, the development of immigration for permanent settlement.

The publication of a new nationality law on 3 October 1981 [Law no. 37/81] resolved the tension between the solution to the particular problem of the maintenance (or loss) of Portuguese nationality by individuals born or resident in the ex-colonies, a solution based on the ius sanguinis criterion, and the general framework for the acquisition of Portuguese nationality. The latter was still governed by Law no. 2098/59, which gave priority to the ius solis criterion. The legislation resolved the tension by opting for the ius sanguinis rule.

The principle according to which all those born in Portugal were considered Portuguese now has the limitation that the children born in Portugal of foreign parents are only considered Portuguese if (i) their parents have habitually resided in the country for at least six years and (ii) have declared their wish to be Portuguese. But the restrictive clause on the acquisition of nationality by

4 In strict terms, the following retain nationality: the Portuguese born in Portugal (mainland or islands), the Portuguese who are born abroad of a father or mother born in Portugal (mainland or islands) or naturalised, a woman who is married to, divorced from or the widow of a Portuguese man in the situation mentioned above, and the children of the latter who are minors [Decree-Law no. 308-A/75, Article 1 (1)]. It was also specified that, after the date of independence, third generation descendants of Portuguese in any of those three situations retained nationality. The only exception to this criterion concerned those born in the former State of India, before it was annexed by the Indian Union in 1961. In this case, the ius solis criterion prevailed [Article 1 (1) e)]. 
the foreign-born children of a Portuguese father, relating to the establishment of residence in Portugal, has disappeared.

This track was followed and reinforced in Law no. 25/94 of 20 October, which is still in force. The claim to Portuguese nationality by children born in Portugal of foreign parents is restricted to

individuals born in the territory of Portugal to foreigners who have resided here with a valid residence permit for at least 6 or 10 years, depending on whether they are, respectively, citizens of countries with Portuguese as an official language or other countries...

[Law no. 25/94, Article 1 c)]

This restrictive policy is extended to the acquisition of nationality by marriage - with the added demand of a period of three years for such effects [Article 3 (1)]; to the requirements for naturalisation - with the inclusion of a new paragraph demanding proof "of an actual connection with the national community" [Article $6 \mathrm{~d}$ )]; and to a broadening of the grounds for the rejection of a naturalisation application - with the new wording of Article 9 a), which places the onus of proof of "an actual connection with the national community" on the applicant for naturalisation. ${ }^{5}$

At the same time, this law introduces the principle of negative discrimination against non-Portuguese-speaking foreigners and their children who are born in Portugal (once again presenting the latter with the effects of their parents' condition), at the level of both the right to native-Portuguese nationality and the conditions for naturalisation. In both cases, the law demands that they have previously lived in Portugal for a longer period (10 years, as against 6 for Portuguese-speakers).

The changes in the Portuguese legislation on nationality correspond to the trend, analysed by Weil (2001), which characterised immigration policies in European countries in a phase of reaction to the newness of the phenomenon. Weil relates different countries' modifications to the nationality regulations to the development of the migratory cycle, arguing that "first, access to nationality was restricted when the law was perceived as permitting easy access to residence without having respected immigration laws. Second, all provisions that did not provide for the facilitate integration of second- and third-generation immigrants were progressively

5 The law makes naturalisation more difficult and restricts its acquisition to adults. So, it assigns the children of immigrants resident in Portugal that were born abroad before migration, to the "second generation" foreign segment. It thus creates an integration problem since, as Piore stresses, "in relation to individual attitudes and behavior, the critical distinction appears not to be the place of birth but the place where one grows up and, in particular, spends his or her adolescence" (Piore, 1979: 65-6). 
Table 6.2 Changes in the law on nationality

\begin{tabular}{|c|c|c|c|}
\hline Date & Legislation & Ius solis & lus sanguinis \\
\hline [1867] & [1867 Civil Code] & [predominant] & [secondary] \\
\hline 1959 & $\begin{array}{l}\text { Law no. } 2098 / 59 \\
\text { Decree-Law no. } 43090 / 60 \\
\text { [Nationality law and regulatory decree] }\end{array}$ & predominant & secondary \\
\hline 1975 & $\begin{array}{l}\text { Decree-Law no. } 308 \mathrm{~A} / 75 \\
\text { [governs the maintenance/loss of } \\
\text { nationality by those born or domiciled in } \\
\text { the ex-colonies] }\end{array}$ & reduces & increases \\
\hline 1981 & $\begin{array}{l}\text { Law no. } 37 / 81 \\
\text { Decree-Law no. } 322 / 82 \\
\text { [Nationality law and regulatory decree] }\end{array}$ & secondary & predominant \\
\hline 1994 & $\begin{array}{l}\text { Law no. } 25 / 94 \\
\text { Decree-Law no. } 253 / 94 \\
\text { Decree-Law no. } 37 / 97 \\
\text { [Nationality law and regulatory decrees] }\end{array}$ & reduces & increases \\
\hline 2006 & $\begin{array}{l}\text { Organisational Law no. 2/2006 } \\
\text { of } 17 \text { April }\end{array}$ & increases & maintains \\
\hline
\end{tabular}

overturned: access to citizenship was thus opened to long-term residents and their children" (Weil, 2001: 32-3).

The second phase would have been provoked by the growing influence of democratic values, the stabilisation of borders, and the acquired experience of immigration. Moreover, in the latter area, it was decisive the recognition of the incompatibility between democratic norms and values and the restrictions on access to nationality, as well as the recognition of the negative effects of those restrictions on national and social cohesiveness.

In the legislative activity of 1981 and 1994 in Portugal, restrictive attitudes characteristic of the first phase still predominated, represented by the predominance of the ius sanguinis criterion. When the XVII Constitutional Government took power following the Socialist Party victory in the 2005 general election, the law was amended once again. For the first time since 1974, a reduction was approved in the residence periods necessary before immigrants themselves or their children (if born in Portugal) may acquire nationality. For the first time, a route was introduced (educational success at the end of the primary education, i.e. Grade 4) to avoid the excessive dragging-out of the effects of the parents' illegality on the children's exclusion from nationality. For the first time, also, the conditions were created for minors born in Portugal of foreign parents and recognised as satisfying the necessary conditions - at the request of their parents - to acquire Portuguese nationality, instead of remaining in an identity limbo until adulthood. In summary, for the first 
time since 1974, the criteria for the right to nationality by place of birth were strengthened over those depending on blood-ties. ${ }^{6}$

\section{The emergence of immigration policies in the 1980s: the control of flows}

Throughout the 1980s, the character of immigration policy was one of reaction to the increase in the resident foreign population, centred on the production of legislation aimed at regulating the flows, on the one hand, and creating and developing a specialist police structure for the purpose, the SEF (Foreigners and Borders Service), on the other.

The clearest indicator of this slow development is the absence, until 1995, of any reference to immigration issues in government programs. The same political low-profiling of the immigration topic in the planning for government is evident in the GOP (Major Planning Options), in which it is only minimally dealt with from 1990. Until 1995, that meant concentrating on questions related to the EU, Portugal's participation in the Schengen Agreement (in 1991) and internal security, plus two active policy measures. These were the extension to immigrants of urban rehabilitation programs, particularly in the sphere of social housing [GOP, 1992] and the regularisation program of illegal immigrants provided for in Law no. 17/96 [GOP, 1993]. The predominating interpretation of immigration in this text is that of a threat - of a disturbing and, to a great extent, undesirable phenomenon [Law no. 1/92 of 9 March, GOP, 1992].

In this phase, a restrictive idea of immigrant rights prevailed, with a broad interpretation being made of the range of constitutional exceptions. Since 1976 the Constitution has laid down the principle of providing foreigners and Portuguese nationals with equal rights, with the exceptions to the rule being political rights (electoral rights, the right to set up parties and submit petitions, and access to office in the organs of state power and of power in the autonomous regions) and the exercise of public duties and others that the law defines. Positive discrimination is possible in favour of foreigners from Portuguese-speaking countries, in that access to certain rights reserved for Portuguese nationals is extended to them [Constitution of the Portuguese Republic, Article 15, (1), (2) and (3)].

However, the latter possibility, which is included in the legislation on nationality and, in general, in the legislation relating to foreigners, is limited by the establishment of the principle of reciprocity. This principle is extended, moreover, to foreigners as a whole with regard to regulation of their ability to vote in local elections [Constitution of the Portuguese Republic, Article 15 (4)]. 
With no limitations expressed in the text of the Constitution, access is provided to the right to services, i.e. education, social security, health and housing (Esteves et al., 1991: 104).

Among the set of rights that, constitutionally, may be restricted, the right to work was the one that was going to be the object of more restrictive regulation. Decree-Law no. 97/77 of 17 March on the regulations covering the dependent work of foreign citizens resident in Portugal remained in effect until 1998. With reference to employers, and foreign immigrants with visas granted by the SEF, it demanded that at least $90 \%$ of the personnel in companies with over five employees should be Portuguese. These restrictions were conditionally eliminated only in the case of work involving foreigners from Portuguese-speaking countries with which bilateral agreements existed: Brazil (1971), Guinea-Bissau (1976) and Cape Verde (1977).

Such a restricted framework was not compatible with the growth in immigration analysed above. It is therefore probable that in the sphere of labour regulations for foreigners, as in others, there was a gap between the demands of the law and actual practice. This kind of gap tends to encourage the growth of informal economic activity and, therefore, undermine the compensatory effectiveness of social policies, while also increasing the asymmetries of power inherent in the system of subordinate labour (Santos, 1985).

The cornerstone of immigration policy in this period was regulation of the entry, stay and departure system for foreigners, instituted in 1981 [Decree-Law no. 264-B/81 of 3 September] and amended in 1993 [Decree-Law no. 59/93 of 3 March]. An analysis of these two pieces of legislation allows us to identify two fundamental immigration policy assumptions of the time.

Present in both these laws is orientation of a long-term precarisation in the foreign immigrant's stay in Portugal, which is consistent, moreover, with the orientation of the nationality law. The validity and programming of the three residence permits described in the legislation illustrate that orientation: the first and the second valid for one and five years respectively and renewable for equal periods, and the third unlimited, though with 20 successive years of residence required. This understanding of immigration as a temporary situation is completed by the absence of any mention of the right to family reunification in either piece of legislation.

In the second place, there was the widespread understanding that immigration could be controlled on an administrative and bureaucratic basis, in particular with regard to the proliferation of entry statuses and the strengthening of the expulsion regulations, which were only defined as such in 1993.

The 1993 law sets out the specific handling (less restrictive than the general one) of the entry and settlement of foreigners from the European Union, incorporating the new Community policy on the free circulation of people and the specific aspects of the reinforcement of this new right among the signatories of the Schengen Agreement. Thus, on the legal level, it represented a 
paradoxical development in the regulation of what were, at that time, the two most important, and socially distinct, immigration flows - from the PALOP and the EU. It was paradoxical because it emphasised the social polarization, repeating it on a political level, according to a principle that restricted rights for the socially most vulnerable sectors and extended them for the most skilled immigrants, on account of the near-total overlapping of the social and geographical differentiation of the flows.

The corollary of centring immigration policy on controlling flows by administratively and bureaucratically obstructing foreigners' entry and settlement in Portugal was to concentrate implementation of this policy within the SEF (Foreigners and Borders Service). This definition of powers, however, contradicted the decision taken, also in 1993, in the Resolution of the Council of Ministers no. 38/93 of 15 May, to give the Ministry of Employment and Social Security the responsibility for "coordinating the measures directed at the full social and occupational integration of immigrants and ethnic minorities". It, thus, in fact, divided the responsibilities for immigration policy between the SEF and the latter ministry (Justino et al., 1999: 282). The effect of the resolution was to broaden foreigners' access to occupational training programs.

The central guidelines of the immigration policy pursued in this period contrast with the results of a continuous increase in the population movements analysed above, with immigration aimed at settlement, especially from the PALOP (but also Brazil). It is not to be concluded from this contrast that the policy pursued was inconsistent but rather that it had other consequences than those intended, in particular an increase in illegal immigration. This consequence is common to most developed countries where, since the middle of the 1980s, there has been a growing gap between "national immigration policy [...] and the actual results of policies in this area" (Cornelius, Martin and Hollifield, 1994: 3).

The reaction to increased illegal immigration, in a democratic political framework anchored in liberal and humanist values, led to regularisation program for illegal immigrants in 1992/3 [Decree-Law no. 212/92 of 12 October].

As is typical of all the legislation analysed, a more favourable treatment was specified for Portuguese-speaking immigrants. It was reflected in reduced demands regarding the conditions of admissibility for legalisation.

A new regularization program in 1996 [Decree-Law no. 17/96 of 24 May] responded to the limitations of the earlier process, though it maintained the different treatment for Portuguese-speaking immigrants. ${ }^{7}$

7 A distinction that was reflected not only on a legal level but also in the application of the law, since the rejection rate of applications for legalization was systematically lower for Portuguese-speaking immigrants than for other migrants (Pires, 2003: 146). 


\section{The consolidation of immigration policies in the 1990s: the problem of integration}

The Socialist government which, in 1995, followed the Social Democratic governments (1986-1995) was responsible for this process of legalisation. The process reveals certain important alterations in national immigration policy, which is confirmed by an analysis of other documents and legislation.

It is possible to discern, since that time, a process of placing immigration regulation questions in a less marginal sphere of government action. Then, for the first time, a government programme included specific sections on immigration [Program of the XIII Constitutional Government, 1995, and the GOP (Major Planning Options) for 2000, 2001 and 2002], which were distributed between the areas of internal administration and social policies. ${ }^{8}$ Of particular note in the program were: the need to improve control of the European Union's external borders as a result of the suppression of internal borders and the increase in migratory pressures from Portuguese-speaking countries; and the need to support immigrants with socially inclusive policies.

Among the measures to implement the objectives defined in the section on "social security and solidarity" in Chapter IV (social policies), paragraph d) is (almost completely) devoted to immigration.

This change in immigration policies may essentially be characterised by the broadening of the object of such policies to the field of integration, in contrast to the earlier concentration on the sphere of regulating flows. The regulation of integration is, in turn, mainly defined as (i) involving a particular case of making access to social rights effective and, additionally, as (ii) depending on the removal of legal limitations on the right to work and, within the constitutional limits, to participate politically and as (iii) depending on the granting of the right to family reunification. Earlier positions persist, however, particularly in the handling of the immigrant question in accordance with the objectives of external policy (above all in the maintenance of the constitutional restriction relating to the reciprocity principle for electoral rights) and the symbolic reaffirmation of the institutionalised national identity narrative (to be seen in the continued justification of the different treatment of Portuguese-speaking immigrants). Also present are the culturalist and ethnicising assumptions on the dynamics of integration, based on the

8 This logic of separation, which places immigration policy either on the level of security policy (when it concerns migrant flows regulation) or on the level of anti-exclusion social policy (when it concerns the promotion of migrants integration), was discontinued in the Program of the XIV Constitutional Government (Socialist Party, 1999-2002) and, essentially, reinstated in the Program of the XV Constitutional Government (a PSD/CDS coalition). However, in the first case, the policy measures were concentrated on the social plane, whereas in the second the security component was given precedence. 
political discourse and revealed, above all, in the linking of the immigration issue with the Romany issue, both subsumed by reference to one and the same category - ethnic minorities.

With regard to the new elements of immigration policy, in the area of integration, their implementation was particularly associated with the legislative and organisational programe. In the first case, it is important to note:

- the implementation of the possibility, constitutionally, for foreigners from countries where the Portuguese have the same rights to take part in local elections [Law no. 50/96 of 4 July];

- the new labour law for foreigners, eliminating the quotas imposed on companies [Law no. 20/98 of 12 May];

- the elimination of legislative inconsistencies that allowed a restrictive interpretation by the administration regarding foreigners' access to constitutionally guaranteed rights to services, in particular in the health area [Order no. 25.360 of 2001];

- the specification of the applicability of the new social policies, on the basis of residence category and not nationality, with the legal base for such being the regulations on the guaranteed minimum income, in stipulating "legal residence in Portugal" as the first condition of allocation [Law no. 19-A/96 of 26 June, Article 5 (1) a)].

At the organisational level, the execution of immigration policy was no longer confined to the action of the Foreigners and Borders Service, with the creation in 1996 of ACIME (High Commissariat for Immigration and Ethnic Minorities), aimed at dealing with the problems of integration [Decree-Law no. $3-\mathrm{A} / 96$ of 26 January]. At a second point, the progressive involvement of immigration issues with the execution of the government's sectoral policies can be observed: the program of the XIV Constitutional Government (1999-2002) included a separate chapter entitled "A policy of full integration for immigrants and ethnic minorities", which consisted of 17 measures for the social and economic integration of immigrants. In 2001, the coordination of these measures led to the creation of an "Interministerial Committee for the Monitoring of Immigration Policy" [Resolution of the Council of Ministers no. 14/2001 of 14 February].

This change in immigration policies had repercussions on the redefinition of ideas on the regulations for foreign entry and settlement in and

9 The perverse effects of the reciprocity criterion are to be seen in the exclusion of voting rights for the nationals of two of the countries with the most immigrants in Portugal Angola and Guinea-Bissau. These are also the countries of origin of immigrant populations in Portugal that most suffer conditions of exclusion and discrimination that favor the emergence of the dynamics of ethnicisation. 
departure and expulsion from Portugal. Though the administrative and bureaucratic rationale was maintained, Decree-Law no. 244/98 of 8 August included two amendments that partially reversed the restrictive nature of earlier policy. The period of uninterrupted residence for a permanent residence permit was reduced from 20 to 10 years [Article 84 (2)] and the opportunity for family reunification was strengthened. In fact, the whole of Chapter V is devoted to this question, defining it for the first time as a right.

In 2001, the law was amended again [Decree-Law no. 4/2001 of 10 January]. Once again, it introduced the principle of positive discrimination for Portuguese-speaking immigrants, for whom the period of uninterrupted residence necessary for a permanent residence permit was reduced from 10 to 6 years [Article 85 (1) a)]. With this law, two innovations were also put into operation: the creation of "temporary presence permit status" and the association between the control of immigrant flows and regulation of the labour market.

The temporary presence permit, valid for a year and renewable for up to a maximum of five [Article $55(4)],{ }^{10}$ was given to illegal foreigners (i.e. those living in Portugal without the appropriate visa) who could prove, if only with a witness, that they had a labour relationship of subordination. In practice, what was granted was a work visa (with validity limited to Portugal) after illegal entry and settlement in the country. The creation of this document represented a new response to the upsurge in illegal immigration at the end of the 1990s, one that sought a problematic reconciliation between two objectives. The first was to distinguish legal and illegal immigration by making a difference in the conditions of stability linked to the residence document awarded in each case. The second was to avoid extreme segmentation of the labour market as a result of the rise in the number of immigrants who remained illegal for prolonged periods.

The repercussions of this legal amendment on the immigrant situation resulted in particular from the effects on the regulation of the labour market associated with it, especially because legalisation of the immigrants' situation also signified the legalisation of their labour relationship. For the first time, the new legislation implied the recognition of a connection between the operation of the labour market and the development of migratory flows. The intervention relating to this connection was also extended, with employers being made responsible for the illegal labour situation of illegal immigrants [Decree-Law no. 4/2001, Article 144 (4)]. ${ }^{11}$

The application of temporary presence permit redefined the conditions of attraction at the destination, in seeking to move against the labour deregulation processes inherent in the informalisation of the segments of economic activity

10 After five consecutive years, holders of permission to stay could apply for a residence permit without a previous residence visa [Decree-Law no. 4/2001, Article 87 (1) o); paragraph $\mathrm{m}$ ) of the same point in the wording given in Decree-Law no. 34/2003]. 
that use illegal immigrant employment. It had effects, simultaneously, on the dynamics of labour flows (operating on the bases of recruitment at the destination) and on the integration of immigrants (operating on the legalisation of their situation and inclusion in the labour market). As a perverse effect, however, the temporary presence permit rule may result in a reinforcement of the dynamics of labour market deregulation on account of the discrepancy between the maximum validity of the document granted, five years, and that of contracts for a limited period, which are legally restricted to three years.

The direction of this new orientation in immigration policy corresponded essentially to the type of measures that, two decades earlier, Piore suggested regulated migratory flows more effectively, in regulating the labour market so as to reduce the size of the secondary sector and, therefore, the demand for migrant labour at the destination (Piore, 1979: 174 and 185-6). According to his argument, this is because "efforts do curtail the secondary sector by curtailing the supply of labour are, thus, likely to have exactly the opposite effect", with the development of illegal immigration and, therefore, the conditions for that sector to flourish (idem: 185). As an alternative, he suggests measures to extend labour market regulation, in particular the reinforcement of minimum standards of rights for secondary sector workers and the establishment of the employers' responsibility for the illegality of the labour situation, instead of the penalisation of the immigrants in this situation (idem: 185-6).

The limits on these changes, especially in the medium-term, lay in the maintenance of the nationality law and, therefore, of the roots of segmentation in the legal area involving immigrants and their descendants. They also lay in the maintenance of an organisational model for frontier controls that was almost exclusively based on entry checks. In other words, the system regulating work migration flows did not include their channelling by institutions from the outset, in particular by the launching of recruitment programs supported by organisations of external representation. On the other hand, the functions and organisation of the Foreigners and Borders Service were changed once again, reinforcing their bureaucratic and administrative rationale: their powers were increased from 20 to 24, in particular to make their activity in expulsion and extradition matters more effective [Decree-Law no. 252/2000 of 16 October].

11 The intervention relating to the connection between migrations and the labor market was also reflected, in the organisational level, by the institutionalisation of cooperation between ACIME and the Employment and Occupational Training Institute, as documented in the GOP (Major Planning Options) text for 2000, 2001 and 2002. In the process of legalisation through the granting of temporary presence permit, that organisational connection of the forms of intervention would also include cooperation between ACIME and the IGT (Inspectorate General of Labor), as laid down in Decree-Law no. 4/2001 itself. 
In the field of integration, too, the immigration policies defined in this period contained certain contradictions, particularly to be seen in the coexistence of "republican" orientations (or, more accurately, those involving the broadening of citizenship on the basis of the residence criterion), clearly predominant, and "ethnicising" orientations. The first, already mentioned, represented the search to cancel the specificity of the immigrant situation as a negative conditioning factor in the access to rights; they generally equate foreigners with the Portuguese on the level of rights. ${ }^{12}$ The second were to be seen in the persistence of cultural and ethnic criteria in the primary definition of the immigrant condition.

In this second area, on the one hand, discursive practices persisted, particularly in the naming of legislative initiatives (systematically referred to as intended for immigrants and ethnic minorities). On the other hand, importance should be given to the measures regarding the Secretariado Entreculturas (Inter-culture Secretariat), created in 1991 [Normative Act 63/91 of 18 February] and reformulated in 2001 [Normative Act 5/2001 of 14 December]. It established the figure of the social and cultural mediator, in 2002, and institutionalised the immigrant association movement (see, in particular, Albuquerque, Ferreira and Viegas, 2000; Machado, 2002: 405-430). The fundamental political and legislative milestones in the latter's institutionalisation as a partner of the state in defining and monitoring immigration policy are the creation of ACIME, the establishment of Cocai (Advisory Council on Immigration Affairs) in 1988 [Decree-Law no. 39/98 of 27 February], and the definition of the legal framework for immigrant associations in 1999 [Law no. 115/99 of 3 August].

In summary, in this second period, immigration issues gained prominence in governmental and legislative activities, on the one hand, and, on the other, immigration policies were marked by a broadening of integration and a reformulation of the ways of controlling flows. In the field of integration, despite the persistence of ethnicising references, the accent was placed on extending immigrant access to rights. In the regulation of flows, the main innovation was the link between border policies and labour market regulation policies. Amendment of the nationality law and repeal of the reciprocity principle in the sphere of political rights were left aside. Thus, the development of "immigrant citizenship" inconsistent with the classical sequence defined by Marshall (1950) was consolidated, an inconsistency already indicated by Marques and Santos (2001: 165).

12 An orientation also present in the establishment of the Welcome to Portugal program (under the Choices program), with the objective of offering "basic courses for foreigners in citizenship and the Portuguese language" [Resolution of the Council of Ministers no. 4/2001, of 9 January]. 


\section{Immigration policies at the beginning of the new century: setbacks}

In March 2002, the PSD (Social Democratic Party) won the general election, which had been brought forward, and formed a coalition with the CDS (Social Democratic Centre). A new immigration policy had been announced by both parties in their election manifestoes and was reaffirmed in the programme of the XV Constitutional Government. ${ }^{13}$ The amendment of the law on the entry, stay and departure of foreigners marks the immigration policy of the XV and XVI Constitutional Governments. Following the dissolution of the Assembly of the Republic by the President of the Republic in 2004, and the call for parliamentary elections, the Socialist Party won the general election with an absolute majority. New changes to immigration policy were announced in the programme of the XVII Constitutional Government, though it is still very early to analyse them. That programme provided for a coordinated policy around the axes of integration, regulation and control.

At the beginning of this new century, we are thus witnessing not only an expansion of the migratory phenomenon in Portugal but also the appearance of new immigration patterns, as well as, simultaneously, the emergence of new controversies about immigration policy.

The change of the immigration policy developed in the second half of the 1990s can be exemplified by the PSD/CDS coalition's amendments to the law on the entry, stay, departure and expulsion of foreigners in or from the national territory [Decree-Law no. 34/2003 of 25 February, rectifying Decree-Law no. 244/98 of 8 August]. The most important amendments were already set out in Law no. 22/2002 of 21 August, which authorized the government to legislate in this area. They are, in particular:

- repeal of the temporary presence permit regulations [Article 55 of Decree-Law no. 4/2001 of 10 January was repealed by Article 20 of Decree-Law no. 34/2003]; ;4

The Programe of the XVI Constitutional Government (2004-2005), formed following Durão Barroso's departure, affirms the intention to continue the work of the former government regarding immigration policy.

14 As a substitute for the regulations on the temporary presence permit, the regulation of labour flows was proposed, from the countries of origin, on the basis of work visas and the signing of agreements with those countries. Migration agreements, as mechanisms for regulating migratory labour flows, especially temporary ones, had already been made in the past with Cape Verde (Decree-Law no. 524-G/76 of 5 July and Decree no. 60/97 of 19 November), with Guinea-Bissau (Decree no. 115/81 of 5 September) and with São Tomé and Príncipe (Decree no. 155/78 of 16 December and Decree no. 34/79 of 21 April). As these agreements were not accompanied by the establishment of institutional channels between the origin and destination, which would allow the flows to be organised, their effect was limited, as the subsequent history of the flows demonstrates. 
- facilitation of the removal mechanisms through creation of the regulations for cancelling visas [with the addition of Article 51-B to Decree-Law 244/98 of 8 August];

- restriction of the concept of "resident" to the holders of "residence permits" [new wording for Article 3], in this way restricting the applicability of the regulations on equal rights between foreigners and the Portuguese;

- definition of an "obligatory annual maximum limit on foreign citizens arriving from third states to carry out an occupational activity" [new wording for Article 36 (2)], to be published in the report on labour needs, now appearing every two years.

This latter objective was already set out in the program of the XV Constitutional Government (2002) in the chapter on Internal Administration: “Establishment of an obligatory annual limit on the number of immigrants from non-Community countries who may enter Portugal" ${ }^{\prime 15}$ This type of pronouncement may generate the dynamics, analysed by Brubaker (1994: 230), of the social rejection of immigration. That author stresses that, when assessed from the viewpoint of the potential immigrants in their countries of origin, entry control is effective. So the image of uncontrolled immigration in the countries of destination results less from the real ineffectiveness of the policies than the assessment of these policies on the basis of unrealistic goals. Moreover, the gap between the declared goals and objectives attained, and not so much the ineffectiveness of immigration control policies, measured according to the growing demand at the point of origin, lies at the base of the public perception of immigration as a process out of control and, therefore, of a possible increase in restrictive attitudes to immigration among European voters.

The new law also increased the difficulty of gaining the right to family reunification, since it is now demanded that the immigrant has resided legally in Portugal for at least a year [Article 56 (1)] before being able to claim it. In the case of its effects on the labour market, changes in the opposite direction are to be noted, changes that expand immigrant opportunities rather than restrict them:

- the ability of holders of temporary visas, in properly grounded cases, to exercise occupational activity on similar terms to those of a work visa [Article 38 (2)], without the activity needing to be provided for in the labour needs report;

- the creation of a new work visa for scientific research or an activity that presupposes highly qualified technical knowledge [Article $37 \mathrm{~b}$ )].

15 In the Programe of the XVI Constitutional Government (2004-2005), the reference to entries was changed to "establishment of an annual limit to the number of immigrants from non-Community countries that may enter Portugal; it should be consistent with their ability to be integrated into Portuguese society". 
The objectives of Decree-Law no. 34/2003 of 25 February involved, overall, the progressive recovery of the earlier strategy of controlling the volume of immigration by reducing immigrants' rights and, particularly, by assuming that the costs for immigrants of the illegality resulting from the abolition of the temporary presence permit system, at a time when the push-factors in the place of origin remained strong, would represent a deterrent factor for new immigrant flows and settlement. Irrespective of the greater or lesser effectiveness of the plan to control flows, that strategy implied the reappearance of an integration situation that made assimilation processes less viable than the process being developed. (Moreover, the strategy was hardly compatible with the removal of the two main obstacles still standing in the way of their intensification: the amendment of the nationality law in favour of ius solis and the repeal of the constitutional principle of reciprocity, as a negative restriction on access to rights, in particular political participation).

The regulations for Decree-Law no. 34/2003, via Regulative Decree 6/2004 of 26 April, introduced policy mechanisms that were not apparent in the law. In particular, it permitted legalisation for those who:

though not possessing the documentation qualifying them for dependent labour, have joined the employment market and have registered with and made the payments due to the social security and tax authorities for a minimum period of 90 days, by the date of the coming into effect of Decree-Law no. 34/2003. ${ }^{16}$ [Regulatory Decree 6/2004 of 26 April, Article 71 (1)]

Mention was not made to the document to be granted to foreign citizens who satisfied those conditions and pre-registered with ACIME [Article 1 (3)] in the 45 days following the entry into effect of the regulative decree [Article 1 (4)]. It was laid down that citizens who satisfied the requirements set out for legalisation would not be disadvantaged by the fact that the employer had not complied with its social security and tax authority obligations, though, for the purpose, they had to present documentary proof of supplying labour [Article $71(7)]{ }^{17}$

In addition to this general opportunity for legalisation, another route was established for foreign citizens who were the parents of minors born until 12 March 2003, provided that they exercised their parental power over

Applicable, therefore, to foreign citizens who had entered the country at least 90 days before 12 March 2003 and not to those who had done so up to that date.

17 According to data published in the press at the end of 2004 ["Immigrants may follow their applications on the Internet, Jornal Público, 19 October 2004], the number of preregistered immigrants was around 53 thousands. It was reported in December ["SEF (Foreigners and Borders Service) summons 8000 immigrants: contributions to the Social Security are a condition", Diário de Notícias, 27 December] that 15, 450 immigrants were registered at the Social Security with the 90 days' contributions requirement and 7721 without confirmation of those contributions. 
them. Under these conditions, according to Article 70 of the same Decree-Law, both the children and parents became eligible to obtain a residence permit, without the need for a visa.

The regulations for foreign minors born in Portugal have, moreover, been complemented with the creation of a national register for foreign minors in an illegal situation in Portugal, to provide a guarantee of access to health services and (pre-school and school) education [Decree-Law no. 67/2004 of 25 March, following what was already laid down in Decree-Law no. 34/2003 of 26 February]. ACIME was made responsible for guaranteeing that right, in combination with the relevant services of the Public Administration [Decree-Law no. 67/2004 of 25 March, Article 3 (2)].

The opening-up to the legalisation of foreign citizens, arising from the regulatory legislation for the law, partly resulted from the pressure applied by immigrant associations and humanitarian NGOs, some with a place on the Advisory Committee for Immigration Affairs. Since 2002, along with the Committee for Equality and against Social Discrimination, this council had included the High Commissariat for Immigration and Ethnic Minorities [Decree-Law no. 251/2002 of 22 November]. The alteration from a body with, hitherto, a single name, was justified by the need for a "structure that had broader means of permanent action, in human and logistical terms, than those formerly provided for, in particular through the places supporting and attending to immigrants" [Preamble of Decree-Law no. 251/2002 of 22 November].

Also in connection with the regularisation of accumulated situations of illegal immigration, though only for Brazilian citizens living in Portugal, the Agreement on the Reciprocal Employment of Nationals was signed in Lisbon between Brazil and Portugal on 11 July 2003 [Decree no. 40/2003 of 19 September]. ${ }^{18}$ Under this agreement, Brazilians living illegally in Portugal would have to prove that they were in the country by 31 July 2003, by means of the pre-registration to be carried out from 25 August of the same year, in order to obtain a work visa. ${ }^{19}$

The slowness of handling these cases was reflected in a low rate of implementation of the legalisation goals, extending the illegal situation of tens of thousands of immigrants. In the meantime, the suppression of temporary presence permit status, in the absence of the organisational conditions that would allow work visas to be granted speedily, resulted in the continuing inflow of new illegal immigrants. In other words, the obligatory limits on

18 The background to the agreement is the Friendship, Consultation and Cooperation Treaty between the Portuguese Republic and the Federal Republic of Brazil, signed in Brasilia on 22 April 2000. The regulations for application of the treaty, with regard specifically to the granting and registration of the status of equality in the rights and duties between Brazilian and Portuguese citizens in Portugal and Brazil, are the subject of Decree-Law no. 154/2003 of 15 July. 
Table 6.3 Chronology of basic immigration legislation, 1976-2005

\begin{tabular}{|c|c|}
\hline Date & Legislation (DR = Diário da República, Official Journal of Republic of Portugal) \\
\hline 1976 & $\begin{array}{l}\text { Decree-Law no. 494-A/76, DR } 145 / 76 \text {, Series I, 2nd Supplement, of } 23 \text { June } 1976 . \\
\text { Restructures the Department of Services to Foreigners, which becomes independent of } \\
\text { the PSP (Public Security Police) and remains directly dependent on the Minister of } \\
\text { Internal Administration. }\end{array}$ \\
\hline 1977 & $\begin{array}{l}\text { Decree-Law no. } 97 / 77 \text {, DR } 64 / 77 \text {, Series I, of } 17 \text { March } 1977 . \text { Regulates the work of } \\
\text { foreigners in Portugal, setting quotas. }\end{array}$ \\
\hline 1981 & $\begin{array}{l}\text { Decree-Law no. 264-B/81, DR 202/81, Series I, 1st Supplement, of } 3 \text { September } 1981 . \\
\text { Establishes the general regulations for the entry, stay and departure of foreigners in or } \\
\text { from the national territory. }\end{array}$ \\
\hline 1986 & $\begin{array}{l}\text { Decree-Law no. 440/86, DR 300/86, Series I, 5th Supplement, of } 12 \text { December } 1986 . \\
\text { Restructures the Foreigners and Borders Service. }\end{array}$ \\
\hline 1987 & $\begin{array}{l}\text { Decree-Law no. } 267 / 87 \text {, DR } 149 / 87 \text {, Series I, of } 2 \text { July } 1987 \text {. Defines the legal framework } \\
\text { for the entry, stay and departure in or from Portuguese territory of nationals from the } \\
\text { Member States of the European Community. }\end{array}$ \\
\hline 1991 & $\begin{array}{l}\text { Normative Act no. 63/91, DR 60, Series I-B, of } 13 \text { March 1991. Creates the } \\
\text { Entreculturas/Inter-cultures programme. }\end{array}$ \\
\hline 1992 & $\begin{array}{l}\text { Decree-Law no. } 212 / 92 \text {, DR } 235 / 92 \text {, Series I-A, of } 12 \text { October } 1992 \text {. The first } \\
\text { regularization programme of illegal immigrants. }\end{array}$ \\
\hline 1993 & $\begin{array}{l}\text { Decree-Law no. 59/93, DR 52/93, Series I-A, of } 3 \text { March } 1993 \text {. Establishes the new rules } \\
\text { for the entry, stay, departure and expulsion of foreigners in and from the national territory. }\end{array}$ \\
\hline \multirow[t]{3}{*}{1996} & $\begin{array}{l}\text { Law no. } 17 / 96 \text {, DR } 121 / 96 \text {, Series I-A, of } 24 \text { May } 1996 . \text { The second regularisation } \\
\text { program of illegal immigrants. }\end{array}$ \\
\hline & $\begin{array}{l}\text { Decree-Law no. 3-A/96, DR 22/96, Series I-A, 1st Supplement, of } 26 \text { January } 1996 . \\
\text { Institutes ACIME (High Commissariat for Immigration and Ethnic Minorities). }\end{array}$ \\
\hline & $\begin{array}{l}\text { Law no. 50/96, DR } 205 / 96 \text {, Series I-A, of } 4 \text { September } 1996 \text {. Alters the Electoral } \\
\text { Registration Law, and the Electoral Law for Local Government Bodies, allowing } \\
\text { participation by foreign citizens on a basis of reciprocity. }\end{array}$ \\
\hline \multirow[t]{3}{*}{1998} & $\begin{array}{l}\text { Decree-Law no. 39/98, DR 49/98, Series I-A, } 27 \text { February 1998. Creates the Consultive } \\
\text { Council for Immigration Issues. }\end{array}$ \\
\hline & $\begin{array}{l}\text { Decree-Law no. } 244 / 98 \text {, DR } 182 / 98 \text {, Series I-A, of } 8 \text { August } 1998 \text {. Regulates the entry, } \\
\text { stay, departure and removal of foreigners in and from the national territory. }\end{array}$ \\
\hline & $\begin{array}{l}\text { Law no. 20/98, DR } 109 / 98 \text {, Series I-A, of } 12 \text { May } 1998 \text {. Regulates the work of foreigners } \\
\text { in Portugal, eliminating the quota system. }\end{array}$ \\
\hline
\end{tabular}

19 Official estimates pointed to 10,000-15, 000 Brazilian citizens being able to obtain legalization. According to data published in the press ["Lula Agreement should legalise the situation of around 14,000", Jornal Público, 5 August 2004, by Ricardo Dias Felner], 31, 000 registrations were carried out, 18,000 immigrants were summoned and only 14,000 satisfied the requirements to stay in Portugal. In October 2004, the Assistant Undersecretary of the Minister for the Presidency stated that " 6955 work visas have been issued this year and 7704 other applications, which only await an appointment to obtain the visa, are being finalised" ["Immigration policy", Jornal Público, 4 October 2004, by Feliciano Barreiras Duarte]. 


\begin{tabular}{ll}
\hline Date & Legislation (DR = Diário da República, Official Journal of Republic of Portugal) \\
\hline 1999 & $\begin{array}{l}\text { Law no. 115/99, DR 179/99, Series I-A, of } 3 \text { August 1999. Defines the legal framework for } \\
\text { immigrant associations. }\end{array}$ \\
2001 & $\begin{array}{l}\text { Decree-Law no. 4/2001, DR 8, Series I-A, of } 10 \text { January 2001. Regulates the conditions of } \\
\text { entry, stay, departure and removal of foreigners in and from the national territory, creating } \\
\text { the residence permit. }\end{array}$
\end{tabular}

\begin{abstract}
Order no. 25360/2001, DR 286, II Series, of 12 December 2001. Establishes access to
\end{abstract} health services for foreigners.

2002 Decree-Law no. 251/2002, DR 270, Series I-A, of 22 November 2002. Creates the High Commissariat for Immigration and Ethnic Minorities, dependent on Presidency of the Council of Ministers (transforming an office formerly involving a single person into an interdepartmental structure).

2003 Decree-Law no. 34/2003, DR 47, Series I-A, of 25 February 2003. Transposes, to Portuguese law, Council Directive no. 2001/51/EC of 28 June, which completes the provisions of Article 26 of the Convention on the Application of the Schengen Agreement of 14 June 1985, and Council Directive no. 2002/90/EC of 28 November, relating to the definition of help with illegal entry, transit and residence. Cancels the temporary presence permit rule.

Decree no. 40/2003, DR 217, Series I-A, of 19 September 2003. Agreement between the Republic of Portugal and Federal Republic of Brazil on the reciprocal employment of nationals.

2004 Decree-Law no. 67/2004, DR 72, Series I-A, of 25 March 2004. Creates a national register of illegal foreign minors, for access to education and health services.

Resolution of the Council of Ministers no. 51/2004, DR 87, Series I-B, of 13 April 2004. Sets the needs for non-Community foreign labour, by sector of economic activity.

Regulative Decree no. 6/2004, DR 98, Series I-B, of 26 April 2004. Regulates the legal framework for the entry, stay, departure and removal of foreigners in and from Portuguese territory.

2005 Joint Order no. 283/2005, DR 64, Series II, of 1 April 2005. Defines the relationship between the IGT (Inspectorate General of Labour), ACIME and the SEF (Foreigners and Borders Service) for the purposes of Article 71 (7) of Regulatory Decree no. 6/2004 (foreign citizens who wish to legalise their situation but whose employer does not comply with social security and tax administration obligations.

the volume of immigration existed as a registration limit and not an actual limit.

This discrepancy between the actual migratory flows and the juridical mechanisms of their regulation sets fundamental problems to immigration policy. Firstly, because the inefficacy of the channels for legal migration contributes for the increasing of irregular migration toward levels above the limit, due to migratory pressure. Secondly, because the existence of a phase of illegality in the migrant's trajectory badly commits the successes on the 
integration policy domain, namely the effects produced by decreasing the terms that extended in time the situation of foreigner.

It is in this context that should be focused the Governmental proposal of the Socialist Party aiming to review the law of entry, stay and departure of foreigners, in or from national territory. Decreasing the gap between the regulation policy objectives and the actual irregular situation of the majority of immigrants in the first phase of settlement in Portugal depends on the extent of changes to be introduced on that law.

\section{References}

Albuquerque, Rosana, Lígia Évora Ferreira and Telma Viegas (2000), O Fenómeno Associativo em Contexto Migratório. Duas Décadas de Associativismo de Imigrantes em Portugal, Oeiras, Portugal, Celta Editora.

Brubaker, Rogers (1994), "Commentary: are immigration control efforts really failing?" in Wayne A. Cornelius, Philip L. Martin and James F. Hollifield (eds.) (1994), Controlling Immigration. A Global Perspective, Stanford, Stanford University Press, pp. 227-231.

Cornelius, Wayne A., Philip L. Martin, and James F. Hollifield (1994), "Introduction: the ambivalent quest for immigration control", in Wayne A. Cornelius, Philip L. Martin and James F. Hollifield (eds.) (1994), Controlling Immigration. A Global Perspective, Stanford, Stanford University Press, pp. 3-41.

Dornelas, António (2001), "Interrogações sobre as perspectivas das relações industriais em Portugal", in AA. VV, O Futuro do Trabalho. Novas Relações e Competências, Oeiras, Portugal, Celta Editora, pp. 507-518 (CD-ROM).

Esteves, Maria do Céu (ed.) et al. (1991), Portugal, País de Imigração, Lisbon, Instituto de Estudos para o Desenvolvimento.

Justino, D., et al. (1999), "A situation in flux between tension and integration”, em AA. VV., Metropolis International Workshop. Proceedings, Lisbon, FLAD.

Machado, Fernando Luís (1997), “Contornos e especificidades da imigração em Portugal", Sociologia, Problemas e Práticas, 24, pp. 9-44.

Machado, Fernando Luís (2002), Contrastes e Continuidades Migração, Etnicidade e Integração dos Guineenses em Portugal, Oeiras, Portugal, Celta Editora.

Marques, Margarida, and Rui Santos (2001), "Politics, welfare and the rise of immigrant participation in a Portuguese suburban context: Oeiras during the 1990s", in Alisdair Rogers and Jean Tillie, Multicultural Policies and Modes of Citizenship in European Cities, USA, Ashgate.

Marshall, T. H. (1950, 1963), “Citizenship and social class”, em Sociology at the Crossroads and Other Essays, London, Heinemann Educational Books, Chap. IV, pp. 67-127.

Massey, Douglas S. (1999), "International migration at the dawn of the twenty-first century: the role of the state", Population and Development Review, 25 (2), pp. 303-322.

Pires, Rui Pena (2003), Migrações e Integração, Oeiras, Portugal, Celta Editora. 
Piore, M. (1979), Birds of Passage. Migrant Workers and Industrial Society, New York, Cambridge University Press.

Portes, Alejandro (1999), Migrações Internacionais. Origens, Tipos e Modos de Incorporação, Oeiras, Portugal, Celta Editora.

Santos, Boaventura Sousa (1985), "Estado e sociedade na semiperiferia do sistema mundial: o caso português", Análise Social, XXI (87/88/89), pp. 869-902.

Weil, Patrick (2001), "Access to citizenship: a comparison of twenty-five nationality laws", in T. Alexander Aleinikoff and Douglas Klusmeyer (orgs.), Citizenship Today. Global Perspectives and Practices, Washington, DC, Carnegie Endowment for International Peace, pp. 17-35.

Werth, Manfred, et al. (1991), “L'immigration de ressortissants de pays tiers dans les États méridionaux de la Communauté Européenne", Europe Sociale, Supplément 1/91, Luxembourg, Commission of the European Communities, Directorate-General for Employment, Industrial Relations and Social Affairs. 



\title{
Chapter 7 \\ The Portuguese Armed Forces \\ Changes and continuities at the turn of the millennium
}

\author{
Helena Carreiras
}

\section{Introduction}

The end of the Cold War, associated with the dilution of East-West tensions and symbolically identified with the fall of the Berlin wall in September 1989, brought with it profound transformations in the framework of strategic orientations, objectives and the organisational structure of the armed forces of Western democracies. These changes have been charted along two main dimensions: on the one hand, the strategic, political definition of the use of force and the management of violence in a new international scenario; on the other hand, the changing relationship between the armed forces and the societies in which they function.

If, in international terms, studies and investigations regarding this topic do not abound, it is even more difficult to find literature where, from a sociological point of view, authors seek to identify and evaluate the impact of such transformations upon the Portuguese military. ${ }^{1}$ In this chapter, a selective evaluation is proposed of the position and evolutionary tendencies of the Portuguese Armed Forces in the framework of the new trends in military organisation and civil-military relations in Western countries.

Taking as a point of departure one of the analytical frameworks most discussed in the recent sociology of military institutions, proposed by Moskos, Williams and Segal (2000) - and (perhaps equivocally) identified as a model of the "postmodern" military - one can observe, synthetically and based upon the available empirical information, the way the Portuguese Armed Forces are positioned regarding some of the variables of this model: strategic orientation (definition of missions and perception of threats); organisation (type of recruitment,

1 Santos (2001) and Matos (2004) have tried to map such changes, but none of them does so from a clearly sociological perspective. 
structure of forces and socio-professional identities); public attitudes towards the military and, finally, patterns of gender integration. ${ }^{2}$

\section{Change in military organisations: a new emerging paradigm?}

One of the most important assumptions in civil-military relation's theory is that armed forces are Janus-faced organisations: on the one hand, they have to assure military effectiveness in order to respond to the changes of the strategic context; on the other, especially in democracies, they must be responsive to wider social values and thus to the society in which they are embedded and which pays for them (Dandeker, 1998; Ammendola, 1999). The dilemmas and tensions originating from this dual frame of reference have been particularly highlighted since the end of the Cold War, and even more after September $11^{\text {th }}$. A number of changes at the broader social-political level - in terms of both the international strategic context and domestic social structures have fundamentally and progressively challenged previous national definitions of strategic interests, conceptions of security and threat, and even existing perspectives regarding the nature of warfare.

At the international strategic level, the most obvious feature of these changes has been identified as the "shift from the 'certainties' of the bi-polar standoff between the two superpowers to a more uncertain, fragmented world of competing centres of economic, political and military power" (Dandeker, 1994: 639). Especially in the past two decades, security issues have been redefined. Traditional approaches based on the classical paradigm of realism, focusing on a strict political-military dimension and a stato-centric vision, have been challenged. ${ }^{3}$ Non-military dimensions of security, considered as "common-risks" which individual nation-states can neither escape from nor deal with alone, have thus come to the fore. The new concept of "risk-society" posited a major emphasis on these new sources of danger that cut across political borders (Shaw, 1998, 1991). Although it should be recognised that this is not a new idea - since Western states have developed a perspective of common security in response to perceived common threats for at least half a century - , some new elements are now decisive. Among them is the emergence of a new and rather "nebulous" category

2 In his book Segurança e Defesa na Viragem do Milénio, Loureiro dos Santos (2001) attempts an analysis using this same model, but based upon a political-strategic reflection and a relative scarcity of empirical information.

3 Barry Buzan's study, People, States and Fear (Buzan, 1991), was one of the first attempts to re-think the core concept of "security", calling attention to its multidimensional nature. While maintaining that states are still the "dominant units", he at the same time criticised the conceptions of security bound to the level of individual states and military issues and called for a broadening of the concept in order to include political, economic, societal and environmental dimensions. 
of political subject, "the international community", whose individual members' rights and interests are increasingly acquiring stature in world politics. As argued by Shaw, "however inconsistently Western states and the UN respond to genocide, human rights abuse, anti-democratic regimes, global poverty and environmental degradation, it is an extremely significant transformation which has turned these issues into definers of world politics" (Shaw, 1998: 78). However, "common risks" affect different groups very unequally and not all of them are military in nature, although some may become a potential source of military threat. As a result, it is difficult for any society to identify the conditions under which certain risks (defined as capabilities not matched to intent) may become identifiable threats (Dandeker, 1994).

Military institutions have attempted to adapt to these different challenges by seeking to achieve greater flexibility in its organisational structures and by responding to pressure from the wider society to conform to civilian values such as social equality. ${ }^{4}$

Prolonging a process that has been developing since the middle of the $20^{\text {th }}$ century, military establishments have restructured their organisational format, accelerating the trend away from mass armed forces towards more technically-based volunteer forces. Traditional armies, based upon general conscription, have given place to more limited formations, professionalised and easily mobilised, following a tendency of reduction of the military contingents and potential. In the course of this process, and in large part as a consequence of technological development, there has been a substantial modification in the ratio between combat functions and support functions (the "tooth to tail ratio"), the second ones acquiring an enormous preponderance. Technological change has fragmented the military institution into multiple specialties and has increased the recourse to non-military specialists for the development and operation of extremely complex arms systems.

On the other hand, especially after the end of the Cold War, military missions have been reoriented, with priority shifting from national territorial defence to multinational interventions aimed at supporting peace and stability at a more global scale (Dandeker, 1998: 84). Although international law after World War II already contemplated this type of mission, the actual number of multinational "peacekeeping operations" suffered a substantial increase since the dilution of East-West tensions and the renewal of the UN's role in world politics. Precisely because this entailed fundamental changes in the nature and scope of military missions and not a mere increase in its number, a distinction has been proposed between the first and second generations of 
peacekeeping. The second type of mission, which took on increased importance among the armed forces' "operative possibilities", may thus be distinguished from the former at different levels. Some of its key features are: 1) complexity and "fuzziness": experience has shown that this type of mission is reasonably unpredictable in what concerns its territorial scope as well as its specific "engagement rules"; 2 ) the armed forces become multinationalised in various degrees and forms. In order to be effective, national leadership has to address interoperability problems, "including not only technology and equipment but also a range of cultural issues arising from cooperation between formations working under quite different national personnel policies" (Dandeker, 1998: 85); 3) they also become multifunctional: military dimensions increasingly interface with local and international political dimensions. The need to interact with a wide variety of political and social actors has challenged the traditional understanding (and practice) of military professionality.

The problem, as Dandeker has put it, is that "changes stemming from the external strategic context and the domestic social structure are not occurring sequentially but simultaneously. Thus, while armed forces in most industrial countries have experienced sharp cuts and restructuring of their organisational format, military personnel are being asked to be prepared for a wider variety of missions encompassing peace support operations as well as traditional war-fighting" (Dandeker, 1998: 85).

One of the models initially proposed to explain the transformations underway during the Post-World War II and the Cold War periods was known as the Institution/Occupation thesis (Moskos, 1977 and 1986; Moskos and Wood, 1988). In this model a set of polarized empirical indicators is identified in a continuum ranging from a military organization that is highly divergent from civilian society to one which is highly convergent with civilian structures. Two ideal-type models are conceptualised: an institutional or divergent model, legitimated in terms of norms and traditional values, where the members of the institution are seen as following a vocation, relying on symbolic rewards and sharing "a purpose transcending individual self-interest in favour of a presumed higher good" (Moskos, 1986:378); and an occupational or convergent model, close to the dominant market rationality of civilian society, where motivations to join or remain in the military are of an extrinsic material and instrumental nature. When this thesis was first presented, Moskos defended the idea that the dominant trend in the American Armed Forces was a shift from a "vocational" to an "occupational" logic, and a corresponding move from institutionalism toward occupationalism. ${ }^{5}$

5 However, it is important to note that, for Moskos, this didn't involve the identification of homogeneous and unambiguous situations on one pole or the other, nor the finding of intermediary situations on a continuum. The proposed hypothesis suggested, rather, the real 


\begin{tabular}{|c|c|c|c|}
\hline Forces variable & $\begin{array}{l}\text { Modern } \\
\text { (Pre-Cold War) } \\
1900-1945\end{array}$ & $\begin{array}{l}\text { Late Modern } \\
\text { (Cold War) } \\
1945-1990\end{array}$ & $\begin{array}{l}\text { Postmodern } \\
\text { (Post-Cold War) } \\
\text { Since } 1990\end{array}$ \\
\hline Perceived threat & Enemy invasion & Nuclear war & $\begin{array}{l}\text { Subnational (e.g. ethnic } \\
\text { violence, terrorism) }\end{array}$ \\
\hline Force structure & Mass army, conscription & Large professional army & Small professional army \\
\hline Major mission definition & Defense of homeland & Support of alliance & $\begin{array}{l}\text { New missions (e.g. } \\
\text { peacekeeping, } \\
\text { humanitarian) }\end{array}$ \\
\hline $\begin{array}{l}\text { Dominant military } \\
\text { professional }\end{array}$ & Combat leader & Manager or technician & $\begin{array}{l}\text { Soldier-statesman; } \\
\text { soldier-scholar }\end{array}$ \\
\hline $\begin{array}{l}\text { Public attitude towards } \\
\text { military }\end{array}$ & Supportive & Ambivalent & Indifferent \\
\hline Media relations & Incorporated & Manipulated & Courted \\
\hline Civilian employees & Minor component & Medium component & Major component \\
\hline Women's role & $\begin{array}{l}\text { Separate corps or } \\
\text { excluded }\end{array}$ & Partial integration & Full integration \\
\hline Spouse and military & Integral part & Partial involvement & Removed \\
\hline Homosexuals in military & Punished & Discharged & Accepted \\
\hline Conscientious objection & Limited or prohibited & Routinely permitted & $\begin{array}{l}\text { Subsumed under civilian } \\
\text { service }\end{array}$ \\
\hline
\end{tabular}

Source: Moskos, Williams and Segal (2000: 15).

More recently, changes in the military have been reinterpreted as the move from a "modern" to a "postmodern" 6 form of organisation and thus a new model -even if more complementary than oppositional to the I/O thesishas been proposed. Moskos, Williams and Segal (2000) posited the thesis that Western developed democracies are moving from a type of organisation

existence of plural models in which the presence of contradictory characteristics is admitted. Therefore, there would be a "compartmentalising" of the military: although some sectors would remain typically military and divergent from civil society-namely, the combat units-others, particularly in the more technical and administrative specialties would come closer to the occupational model.

6 The way in which the term "postmodern" is used in this proposal has very little to do with general academic conceptions of postmodernism. The authors recognise that there is probably only one area of overlap: the predictions of cultural relativism and a breakdown of traditional lines of demarcation between civil society and military. They note that "the framework for analysis (...) is not postmodern at all" and even that the editors and chapter authors of the book "are quite orthodox positivists"(!) (Moskos, Williams and Segal, 2000:273). In this sense, there is a conceptual stretching which may cause more confusion than clarification of the described tendency. For a thorough criticism of the identified paradigmatic change cf. Booth, Kestnbaum and Segal, 2001. 
associated with nationalism, to an organisational form adapted to a new world system and to the erosion of traditional forms of national sovereignty. While the modern military was based on "a combination of conscripted lower ranks or militia and a professional officer corps, war-oriented in mission, masculine in make-up and ethos, and sharply differentiated from civilian society", the new post-modern type "undergoes a loosening of ties with the nation state. The basic format shifts towards a volunteer force, more multipurpose in mission, increasingly multipurpose in makeup and ethos and with greater permeability with civilian society" (Moskos, Williams and Segal, 2000: 1).

At the global societal analytical dimension, five major organisational changes are highlighted: increasing structural and cultural interpenetrability between civilian and military spheres; diminution of differences within the armed services based on branch, rank and type of functions; change in military purpose from war-fighting to missions that cannot be labelled as military in a traditional sense; increased use of military forces in international operations legitimised by entities beyond the nation-state and finally, internationalisation of the military themselves.

Battistelli has argued that all these changes can be placed along the classic institutional/occupational dichotomy proposed by Moskos to describe the transition from an early modern to a late modern military organisation (Battistelli, 1997). The same seems to happen with correlated changes at the organisational analytical level, namely in terms of the dominant professional ideal (movement away from the warrior-hero type towards the emphasis on the soldier scholar and soldier-statesman ideals), the increasing use of civilian personnel, fuller integration of women and acceptance of homosexuals and more tolerance of conscious objection and alternative forms of military service.

One important question that can be placed regarding the analytic relevance of this new frame is, however, that of knowing whether we are in fact facing the emergence of a new paradigm, or, on the contrary, if the identified changes extend or even "radicalise" tendencies clearly emerging during the period of modernity. Booth, Kestnbaum and Segal have argued in this last direction, underlining that while some of the identified changes do not seem to have historic precedents, the majority represent global efforts at readapting existing force structures to new contingencies, something that the armed forces and other organisations have always done during the modern era: " $(. .$.$) the thesis of the postmodern armed forces is not at all postmodern,$ but instead a distinctly modern effort at theoretical construction, undertaken to capture a host of structural adaptations to environmental change." (Booth, Kestnbaum and Segal, 2001: 336-337). ${ }^{7}$

It is based upon this understanding that we seek to use some of the analytical dimensions of the model proposed by Moskos, Williams and Segal to observe the Portuguese Armed Force. 


\section{The Portuguese Armed Forces and the international scenario}

\section{Strategic orientations: perception of threat and mission definition}

In spite of the relevance of the role performed by the military in the transition process towards democracy in Portugal, its progressive withdrawal from the political scene has been accompanied by a process of objective and subjective marginalisation ${ }^{8}$ which has continued until the present time. The Portuguese Armed Forces arrived at the end of the Cold War period in a particularly difficult situation in terms of material obsolescence, relative absence of strategic orientation and shrinking budgets, while experiencing a climate of distrust between politicians and members of the military (Carrilho, 1994; Matos, 2004).

The lack of clear defence policies has been systematically pointed out and made clear by the actual absence of an up-dated strategic concept of national defence. Santos has put it bluntly: "no one knows which perception the Portuguese democratic political power has regarding potential threats. (...) This unusual situation, unique among Western countries, is due to the complete obsolescence of state structure for security and defence issues" (Santos, 2001: 184). As far as mission definition is concerned, similar criticisms have been echoed, especially from within the military institution itself. According to some of these analysts, the nature of military missions that emerges from official documents seems to be broad enough as to cover any possible situation regarding the use of military force (Santos, 2001: 185). Santos notes that the result of this "strategic vacuum" is that the organisation, equipment and utilisation of military forces are taken on a case-by-case ad hoc basis, with all the technical and economic problems this attitude involves. Others underline the inadequacy of existing legal frames and the perverse effects that a merely reactive (and often delayed) attitude on the part of political leaders has on the international perception of the Portuguese military (Pinto, 2002: 185).

Nevertheless, apart form these criticisms, it is possible to identify some general tendencies in the political definition of defence orientations. Contrary to the opinion of some significant sectors of the country's political and military elite, which continued to adopt an isolationist attitude in the famous "collaborating neutrality" line that prevailed during the international conflicts of the

7 On the other hand, some authors have recognised that "the arguments invoked to justify the emergence of a new type of postmodern armed force were convincing at the time when they were proposed; however, following 11 September, 2001, some of them will have to be rethought, based upon the transformations registered in terms of public opinion, perception of threat, and a series of other key issues" (Callaghan and Kernic, 2003: 43).

This phenomenon of the relative marginalisation of the Armed Forces has in fact been experienced by those countries which have intensified the change towards the referred postmodern paradigm in civil-military relations (Booth, Kestnbaum and Segal, 2001). 
twentieth century, ${ }^{9}$ the participation of the Portuguese military in international missions has become an increasingly important area for military action. The need to build a system of forces capable to respond to national commitments in NATO and the European Union, as well as the participation in multinational peacekeeping missions, had already been identified as a goal to reach in the Conceito Estratégico de Defesa Nacional (National Defence Strategic Concept) defined in 1994. Furthermore, in the Livro Branco da Defesa Nacional (White Book of National Defence) of 2001, the importance of the new missions is emphasised, even though on par with the traditional defence of the integrity of the national territory, and of participation in the collective defence within NATO.

The Conceito Estratégico de Defesa Nacional, revised in 2003, also promoted, and in a more clear form, the reevaluation of the Portuguese military participation in foreign missions, an aspect which has continued to be emphasised by political leaders. In declarations to a newspaper in 2005, the then Minister of Defence, Luís Amado, highlighted the fact that the priority missions of the Portuguese Armed Forces would be exactly those referring to the international commitments and the support of foreign policy within the framework of NATO and the European Union. According to his perspective, the ability to affirm the political personality and identity of Portugal as a sovereign State would occur through participation "in the new frontiers in which the security of the country regarding regional security is decided (...). For this, we need to move from a vision (...) which is still very static and territorial, to one (...) of rapid response and force projection, of interoperability and joint action." 10

Although the Portuguese troops had already been modestly present in United Nations operations, especially in Angola and Mozambique, ${ }^{11}$ it was the presence of a Portuguese contingent in Bosnia in 1996 that signalled a real inflection of policy in this domain, in the sense that some analysts have defined as the "Europeanisation" of the Portuguese defence policy (Vasconcelos, 1999). In this year, the so-called "new missions" represented nearly half of military operational expenses (46\%) and approximately $12 \%$ of the defence budget. On the other hand, the Bosnian experience revealed a growth of support in public, military and political opinion regarding the participation of the Portuguese military in multinational operations and peacekeeping missions

9 The Portuguese position regarding a possible involvement in the Second Gulf War was identified as a good example of this attitude: while supporting a western coalition, Portugal was presented as a "non-belligerent" state.

10 Interview in Expresso [Portuguese weekly paper], June $4^{\text {th }} 2005$.

11 Portuguese military observers have joined various UN missions, but in a limited manner: UNOGIL in Lebanon in 1958, in Namibia in 1989; ONOMUZ in Mozambique, UNAVEM II, UNAVEM III and MONUA in Angola. 
(Vasconcelos, 1999; Sousa, 1999; Carreiras, 1999), and initiated a systematic presence, even if not very expressive in numbers, of the Portuguese military in international missions. In 2002, for example, the Portuguese Armed Forces mobilised 1337 soldiers in peace related operations conducted under the auspices of NATO in Bosnia (SFOR-331), Kosovo (KFOR-15), Macedonia (FYROM-6), Afghanistan (ISAF-21), and of the UN in Timor (UNTAET/UNMISET-964). ${ }^{12}$

However, old policy dilemmas - brought together in the "Angola or Bosnia" debate - became extremely visible during the Kosovo crisis, when the national capacity to maintain troops simultaneously in more than one operation was severely tested..$^{13}$ The ambiguities and lack of strategic definition of Portuguese defence policy emerge thus as a major source of civil-military tension in a context where growing internationalisation seems to be the unavoidable "destiny" of the Portuguese military.

\section{Organizational change and the dominant military professional}

\section{Force structure: from conscription to the all-volunteer force}

Following a generalised tendency in most of the Western world, Portugal carried out, already in the beginning of the twenty first century, the transition between conscription and an exclusively voluntary force in peacetime. The constitutional reference to compulsory military service was eliminated during the constitutional revision of 1997 and, two year later, a new law of military service (Law 174-99) established that which could be considered the major challenge of the reorganisation process: the institution of an exclusively voluntary force in peacetime, which would be complete in 2004 after a four year transition period.

This new model developed after a decade of slow - not always consensual, but doubtlessly clear - tendency towards professionalisation of the armed forces. The approval in 1991 of Law no. 22/91 (a revision of the Law of Military Service of 1987) constituted an important step in this direction, through the creation of a mixed "semiprofessional" system, based upon temporary contract regimes. The approval of the regulatory framework of this new model in 1993, aimed essentially at a rationalisation of means (reduction in the number of steps and departments of command) and optimization of relations between the two components of the system of forces: the territorial component (based upon compulsory military service) and the operational component (based upon compulsory recruitment), as well as a correct utilisation of human resources (MDN, 1998). Two fundamental changes were introduced: a) a reduction in the time of

12 Information available in the Anuário Estatístico da Defesa Nacional, 2002 (MDN, 2002).

13 Eventually, this led later to the withdrawal of Portuguese soldiers stationed in the Kosovo region in order to ensure the Portuguese military presence in East Timor. 


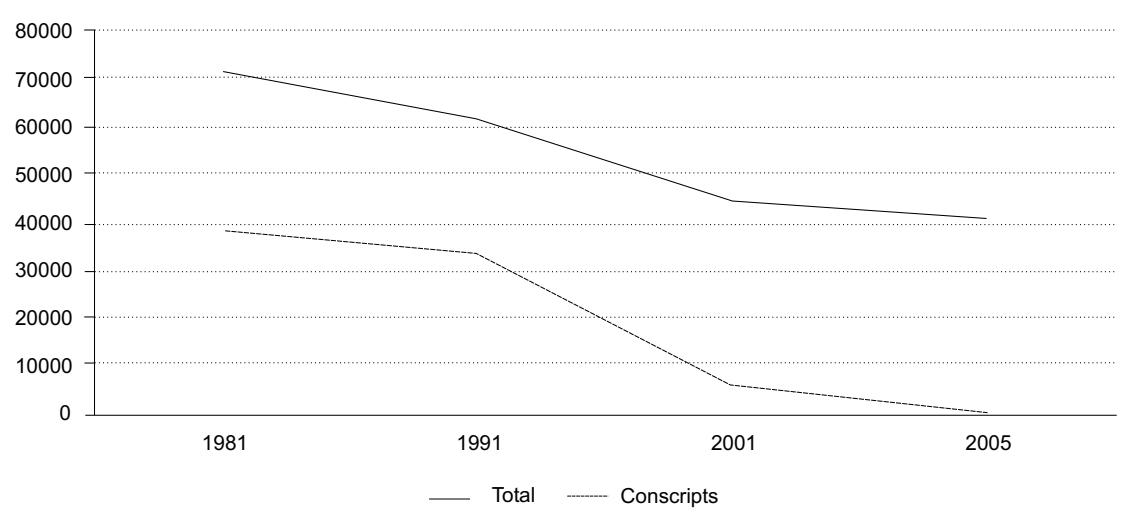

Figure 7.1 Total military personnel and conscripts in the Portuguese Armed Forces (1981-2005) Source: Ministry of National Defence, data provided by the General Directorate of Military Personnel and Recruitment.

compulsory service; b) the creation of new categories of "voluntary" and "contract" service.

Both measures must be analysed in the context of a more ample process of transformation of the Portuguese Armed Forces in terms of the reduction of forces and the general re-dimensioning of the institution. Between 1989 and 2005, a reduction of $41.9 \%$ of the total military force effectively occurred, corresponding to a decrease from 72,926 to around 41,000 (figure 7.1). This decrease occurred for two main reasons: the reduction in the number of conscript soldiers and an identical reduction of the personnel in the permanent structure (cf. Carrilho, 1994: 121/127).

The reduction of conscription time to 4 months was one of the first indications of a shift towards what was referred to, in the law as well as in other documents and promotional material, as "a new conception of military service", based on the key-concepts of modernisation and professionalisation. However, the most important element of the model was the second measure: the introduction of special recruitment regimes of a voluntary nature. Under the new framework, after three to four months of basic training (SEN), volunteer soldiers could serve for a period of up to 18 months - the voluntariado regime - and then apply for a fixed-term contract - the contrato regime. A set of economic incentives was established in order to make these new regimes attractive to young people. These included vocational orientation, access to education, professional training, social security, financial allowances, fringe benefits and support for re-integration into civilian life after the end of the contract.

In spite of initial ambitions, this model began to show various weaknesses soon after being implemented (MDN, 1998; UAL, 1998), eventually being considered excessively expensive, of dubious effectiveness, a generator of 
instability in the system and de-motivation among youths and, above all, reinforcing social inequality. ${ }^{14}$

It is no wonder, then, that in the context of the transition to an exclusively voluntary force, questions were raised regarding the ability to attract candidates or to retain them in the ranks. One of the greatest problems confronted by the previous system was exactly that of the ability to attract and retain volunteers, as well as of an ineffective application of the established incentives system (MDN, 1998).

Thus, apart from centralisation on the organisational level, various other measures were proposed with the aim of facing the challenge of professionalisation, specifically regarding the attraction of a sufficient number of qualified personnel. Immediately, and probably as the most important axis of the model, a renovated policy of socio-economic incentives was announced, including access to academic qualifications and professional certifications, support in entering the job market, and additional measures of preferential treatment in public programs and institutions after the completion of the contractual term (Decree-Law no. 320-A/2000). Furthermore, the importance of the public relations dimension of the recruitment policy was emphasised, as was the possible increase of the proportion of civilian personnel and women in the ranks.

Some analysts, however, showed doubts as to the facility of implementation. Referring to the viability of that which was designated as the "professionalised" model, Mira Vaz shared this apprehension regarding the effectiveness of the incentive system: "Considering the difficulties that other countries with higher financial incentives continue to experience, the question will also not be easily resolved in Portugal" (Vaz, 2001: 70). A sceptical position was also assumed by Loureiro dos Santos, referring to the safeguarding clause by which the government could resort to conscription, in case the number of volunteers did not satisfy the needs of the system of forces: "We will see if there shall be enough courage to enact this clause, given that it is almost certain that this will be necessary" (Santos, 2001: 188).

In any case, although it is early to evaluate the results of the present all volunteer recruitment process, the data relative to the first incorporations have not justified the more pessimistic forecasts. Considering, however, that the ability to attract volunteers to the armed forces has historically depended upon factors such as the state of the economy, one must carefully evaluate the

14 Difficulties involving organisation and the lack of infra-structures implied that only a limited percentage of suitable citizens would be effectively incorporated. Although this had been occurring throughout the 1980s (and even before), the rate of incorporation continually diminished between 1992 and 1998, descending from 52\% to $31 \%$; since only some qualified citizens were effectively incorporated, the system would thus damage the principles of equal treatment. 
impact and evolution of this type of variable upon personnel policy design. Some of the stated tendencies, namely the attention to civilian personnel and the need to diversify the potential target-public for recruitment, are important elements of this new frame, which is common to the various countries which have adopted similar reforms.

\section{Organisational identification: institutional, occupational} and "postmodern" trends

Various indicators point to the existence of a plurality of orientations in the Portuguese Armed Forces, both regarding organisational structure and individual and collective identities.

If we concentrate on the first dimension, and particularly on the constitution of an all-volunteer force, it is possible to discern a clear tendency in the occupational direction. In previous works, there has been an ample illustration of this movement, towards the intensification of occupational appeals for military recruitment (Carreiras, 1995, 1997). The transition, since 1991, to a semi-professional system was effectively accompanied by the production of brochures, fliers, posters, and above all, by a broad media campaign, projecting a new image of the armed forces. Military service began to be presented to young people as an attractive project, an opportunity for professional qualification and an instrument of personal promotion..$^{15}$ The valuation of techno-professional aspects and a clear distancing relative to the traditional military ethos seems to have been evident in this new model. Although appeals of the institutional type were not lacking, the emphasis was decidedly attributed to occupational motivations. Nevertheless, this "occupational" orientation showed to be more intense in the discursive and symbolic dimension than in concrete reality, considering that many of the measures proposed had not been very successful, the same happening with the early plans to modernise and re-equip the forces.

One decade later, at the moment of transition towards the all volunteer force, the same type of appeals accompanied the recruitment efforts. However, concerns prevailed over institutional aspects, which is clear in the Livro Branco da Defesa Nacional (MDN, 2001): “(...) the existence of a reference to values based upon patriotism and ethics, the formation of a spirit of mission and the availability of a variety of diverse and effective incentives are conditions to take into account in the new model of professionalised military service.

15 "The developed legal model is intended to make the young person view military enlistment as a demanding professional activity of high public interest, counterbalancing the inconveniences of its eventually short duration with adequate stimuli to re-implant the citizen into active non-military life, enriched by the instruments useful for integral human success" (Portaria 227-B/92, Dr. II series, no. 169, 24/7/92). 
Their absence would reduce such service to a mere technical offering, (...) and, quite probably, would turn its base of recruitment into a universe of outcasts. To create the conditions that prevent this type of perverse and undesirable development, must be an obligation and a commitment on the part of the political power."

Furthermore, and still at the level of organisational analysis, various indicators point to the relative predominance of conservative forces of an institutional nature.

One of these indicators refers to the question of military unionism and professional representation. In spite of a growing opening up towards various forms of professional association, the constitution of military unions was still prohibited in 2005, and the Lei da Defesa Nacional e das Forças Armadas (LDNFA) imposed several restrictions on its soldiers in terms of civic and political rights. After more than a decade during which various professional interests' associations were created, ${ }^{16}$ some alterations were introduced in the law, with the goal of eliminating previous restrictions, namely those relative to freedom of expression and of association. In 2001, the Portuguese parliament approved an alteration of Article no. 31 of the LDNFA, according to which military personnel would begin to be covered by the general domain of the freedoms of expression, assembly, demonstration, association and collective petitioning, making an exception, though, of rigorous non-partisanship, of their not being able to freely express themselves regarding the handling of the national defence policy, of endangering the cohesion and discipline of the armed forces or even of "using their weapon, their post or their function for any political or unionist intervention." Although some authors do not hesitate to identify in these transformations the emergence of military unionism in Portugal (Matos, 2004: 237-242), these developments were considered relatively limited by the media as well as by various military sectors (Santos, 2001: 195), given that the new rights thus consecrated referred exclusively to the professional/deontological dimension, excluding, in practice, any type of unionism or political involvement.

The way in which the Western countries have come to deal with the question of representation of soldiers' interests has been extremely diversified, a common model or uniform practice not existing in the current democracies (Carrilho, 1994: 158; Bartle and Heinecken, 2006). However, the prudent form with which the new scheme of representation of the socio-professional

16 In the end of the 1980s, various associations began to be constituted: Associação dos Militares na Reserva e na Reforma (Association of Reserve and Retired Soldiers, ASMIRR), 1987; Associação Nacional de Sargentos (National Association of Sergeants, ANS), 1989; Associação dos Oficiais das Forças Armadas (Association of Armed Forces Officers, AOFA), 1992; Associação Nacional dos Contratados do Exército (National Association of Contracted Army Members, ANCE), 1996. 
interests of soldiers in Portugal was institutionalised appears to be evident, if we compare it with that of countries such as Holland. There, in the end of the 1990 s, some large unions represented the interests of approximately $80 \%$ of the personnel in the defence sector. Its action frequently being combined with that of civilian unions, these organizations acquired a growing influence and an effective negotiating ability in terms of salaries and careers (Van der Meulen, 2000).

Attitudes regarding cultural diversity, and specifically those regarding sexual orientation, are the aspects of the model herein referred in which the conservative institutional forces seem to be more expressive. While the reactions to the entrance of women in military service do not suggest strong resistance, the theme of homosexuality remains taboo in the armed forces, which essentially reflects the general social situation. This question, which in some countries has inspired heated debates, while in other has been somewhat resolved (or, at least, "pacified"), does not exist in Portugal: the presence of homosexuals in the armed forces is not even designated as a politically relevant question. The invisibility of the problem results from the fact that it has not become a theme of discussion. Although the legal restrictions regarding the presence of homosexuals in the military service have ceased to exist, the current practice is that of discretely excluding those members who explicitly indicate a homosexual orientation. As Santos notes, "If there should be any knowledge that a certain soldier is homosexual, he risks being isolated and marginalised, in a corps whose gregarious nature is very important (...) [this] can lead to an attitude of voluntary leave, which in fact functions, in the end, as a punishment" (Santos, 2001: 194). The same author calls further attention to the fact that there is a generalised use of derogatory and offensive terms to label those who are suspected of being, or assumed to be, homosexuals.

Turning now to a micro-sociological perspective, from the point of view of professional identities, there is ambivalence in the orientations of Portuguese soldiers. Data obtained through surveys conducted throughout the 1990s confirm the growth of occupational orientations among some categories of military personnel, but also the fact that institutional orientations have maintained relative predominance. A representative survey to officers of the three branches of the armed forces conducted in 1990 (Carrilho, 1990), showed that the occupational motivations for joining the military profession were dominant in the Air Force, while in the Navy and the Army the officers proved to be closer to institutional values. In any case, Carrilho noted that, at this moment, a plural identity model could be considered dominant (Carrilho, 1994: 152). At the end of the decade, another survey to soldiers who participated in the IFOR an SFOR missions in Bosnia-Herzegovina also showed a diversity of orientations (Carreiras, 1999). The results pointed to a considerable weight of institutional factors as reasons for adhesion to a military career, that is, factors associated to the traditional military culture and values (with 
an emphasis upon aspects such as national service or the esprit de corps), as well as to expressive and self-centred factors, such as a "search for adventure" or "personal test", which authors such as Battistelli associate with the so-called paradigm of the postmodern military (Battistelli, 1997); whereas these last factors were those mostly underlined by enlisted members, the officers and NCOs were the groups in which the greater percentage highlighted the institutional factor "desire to serve the country".

\section{Public attitudes towards the military}

The aforementioned transformations concerning the armed forces, namely the end of the draft, force reduction, and involvement in peacekeeping missions, have usually been backed by considerable majorities of public opinion. According to recent national surveys, public opinion has slowly but clearly shifted to support a totally voluntary system of military service. In 1996 about two thirds of the population supported an all-volunteer force, versus $31.5 \%$ who still preferred conscription (Carrilho, 1998). The same proportions held in 1999 (Matos and Bacalhau, 2001: 93).

Likewise, participation in peacekeeping missions has been generally welcomed. In Portugal, as seen above, political and military leaders have been rather conservative regarding the international involvement of the military. However, from the moment Portuguese troops were deployed to the IFOR mission in Bosnia, positions started to change, moving towards a clearer will to participate in post-Cold-War military missions. Not only were the armed forces willing to intervene internationally, but already in 1993, public opinion was also favourable to an European operation in the Balkans. In 1996 more than $2 / 3$ of the Portuguese public supported the country's participation in the IFOR mission.

The presence of Portuguese soldiers in Bosnia became one of the major media events in the country and contributed to an increasing visibility of the Balkan conflict. In fact, after the deployment the media started to give much more attention to the situation in Bosnia. Between January and August of 1996, 25 newspaper, radio and television channels kept 150 permanent reporters in Bosnia. During the first months, soldiers had many reasons to complain and their complaints were immediately reported by the journalists. The absence of previous experience in this type of mission and, above all, the bad weather conditions (previous participation had always taken place in Africa) resulted in various difficulties of installation and inadequate equipment. More than other national contingents, Portuguese troops had to adapt to the new European scenario. The novelty of the whole experience resulted in an unprecedented attention and support given to the armed forces and the military's new missions. 


\section{Patterns of gender integration}

Regarding the role of women, the model under analysis suggests that the present situation in terms of female military integration reveals the tendency towards the new emerging paradigm. Whereas in the "pre-modern" era, women were generally excluded from military service, the period of advanced modernity is characterised by partial integration, namely the abolition of exclusively female corps, but also by the persistence of reduced levels of representation and resistances to the incorporation of women in combat functions. On the contrary, the post-modern military would coincide with strong pressures in the direction of a total opening of the military specialties and units to women.

To be sure, there has been a real tendency towards the intensification of female recruitment in the armed forces of the Western countries over the past three decades. Although the rhythm and characteristics of the process have varied significantly, in the beginning of the $21^{\text {st }}$ century, all the member countries of NATO had recruited women, increased their representation in the ranks and eliminated many of the previously existing conditions (Carreiras, 2002a, 2002b). However, it is important to note that, at present, in spite of this tendency to eliminate discrimination and equalise status between service members, occupational restrictions still exist and women are largely excluded from many combat related areas and functions. They have limited representation in higher hierarchical posts and power positions within the military system. They are not always readily accepted, but often have to face hostile reactions. Empirical data show that even when formal/legal integration has been accomplished, effective social integration has not necessarily followed (Winslow and Dunn, 2002). Moreover, while recognising that those states that have made more formal commitments are more likely to carry out integration, Moskos, Williams and Segal emphasise the fact that "de jure policies do not automatically translate into de facto opportunities, and domestic interest groups know they must use both legal and political instruments to ensure that they do" (Moskos, Williams and Segal, 2000: 270).

Let us observe, in a comparative perspective, some of the indicators of this situation, by first analysing global representation levels (figure 7.2).

In the year 2000, approximately 289, 000 women performed their functions in the armed forces of NATO. Representation levels varied then between less than $1 \%$ in the cases of Poland or Turkey and $14 \%$ in the United States. In 2005 percentages ranged from $0.47 \%$ in Poland and $20 \%$ in Latvia.

In spite of having begun female recruitment later, Southern European countries such as Portugal and Spain have made notable progress in terms of the numeric representation of women in the armed forces. The data relative to Portugal show the amplitude of values attained if compared to those of other countries and, above all, if we consider the relatively late moment in which 


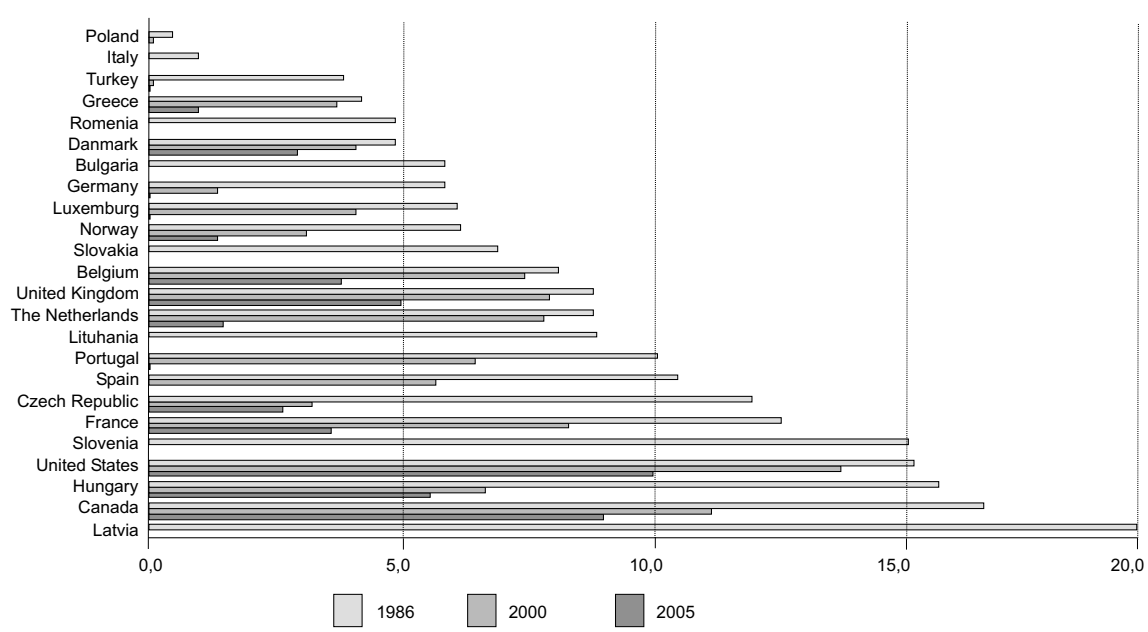

Figure 7.2 Percentage of women in the Armed Forces of NATO, 2006

Note: Percentages of women in the total active force, including conscripts.

Sources: Stanley and Segal (1988: 563); data from 2000; Carreiras (2005); Annual reports of the Committee of Women in the NATO Forces (http: //www. nato. int/issues/women_nato/index. html).

the process began in this country. Numbers increased regularly during the last decade of the $20^{\text {th }}$ century, a fact that, associated with the reduction of military personnel, originated an accentuated growth of female representation: if in 1994 the 1,300 Portuguese women soldiers still represented a residual percentage, in the year 2002 there were approximately 3, 100 female soldiers, constituting $8.5 \%$ of a global force of 36,000 troops. This growth in absolute numbers was clear until 1998; after that, numbers seemed to stabilise around 3,000. From 2001 absolute numbers started to rise again and in 2006 there were 4399 women in the Portuguese Armed Forces, representing 12\% of the total personnel pool.

The occupational distribution of female soldiers reveals, in its turn, a recognised and therefore unsurprising pattern. Data available for 13 nations (Carreiras, 2006) show that in 2000, more than two thirds $(70.4 \%)$ of female soldiers were concentrated in health and support functions (personnel, administration, logistics), $17.5 \%$ in technical areas (engineering and communications) and only $7 \%$ occupied positions in more operational specialties or in the combat arms (artillery, infantry, cavalry). In Portugal, these values were $81.6 \%, 10.4 \%$ and $8 \%$ respectively (figure 7.3 ).

Even when the relative weight of each of these occupational areas within the organisational structure is taken into consideration, women are clearly over-represented in traditionally female specialties. In effect, support 


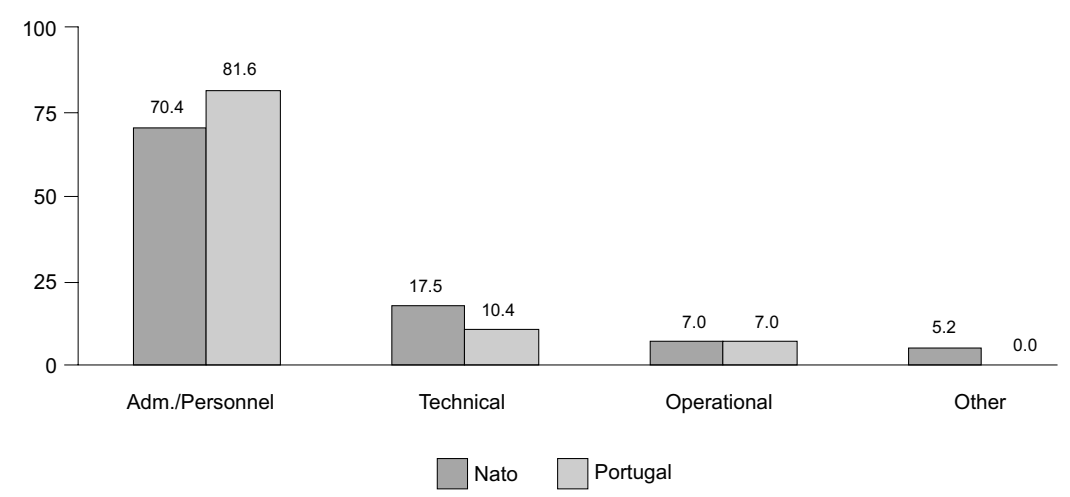

Figure 7.3 Occupational distribution of female soldiers in NATO and Portugal (2000) (\%) Source: Carreiras (2006); Annual reports of the Committee on Women in the NATO Forces.

functions in the areas of personnel, finance, administration and health services employed approximately $46.1 \%$ of the NATO's military personnel, with a percentage of more than $70 \%$ in the case of women. The opposite occurred in the technical areas, and in particular in the operational areas, where this asymmetry was also extremely visible: $22.2 \%$ of military personnel were concentrated in this last type of function, versus only $7 \%$ of women.

In Portugal, we also have data that allows for the evaluation of the relative weight of women within each occupational area. In the same year, they continued to be over-represented in the areas of support and health, constituting $19.8 \%$ and $12.2 \%$ respectively of the total personnel pool in each of those areas. One should note, however, the fact of their representing $5.5 \%$ of soldiers placed in "technical" specialties (engineering and communications), a percentage which, while below the general average of female representation in the armed forces, was still much higher than that registered in operational areas (combat arms) (1.9\%).

Regarding hierarchical representation, around half of all female soldiers in NATO were concentrated in the category of enlisted soldiers (49.9\%), $36 \%$ were NCOs and $15 \%$ officers. Contrary to that which occurred regarding occupational representation, female distribution among the various hierarchical categories was much more balanced when compared with that of the organisational structure: although in absolute terms, women were found to be over-represented in the category of enlisted personnel, they were only slightly under-represented in the categories of officers and NCOs (figure 7.4).

However, the relative percentages within each hierarchical category point to another situation. Due to their reduced absolute number, women were a minority in the various categories: on average, in the NATO countries, women 


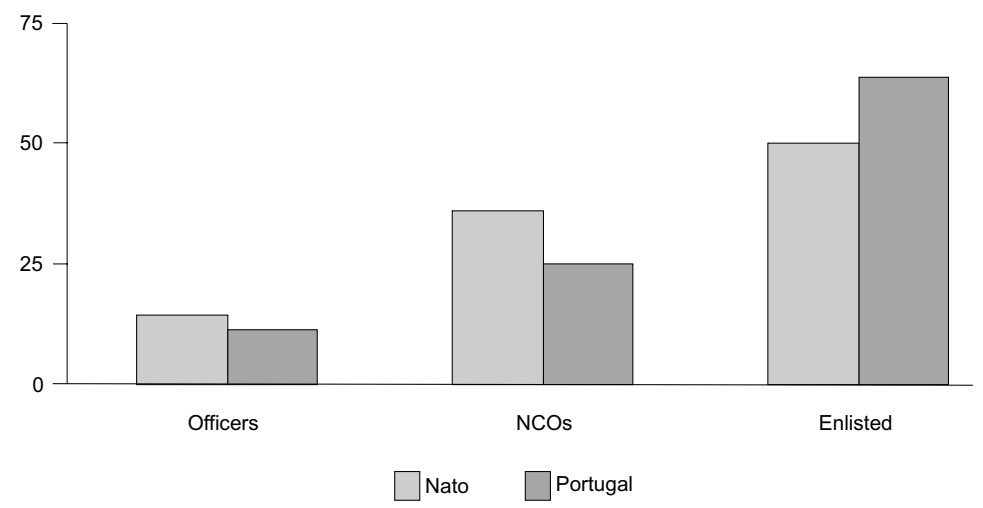

Figure 7.4 Hierarchical distribution of female military professionals in NATO and in Portugal (\%) (2000)

Source: Carreiras (2006); Annual reports of the Committee on Women in the NATO Forces.

constituted $6.9 \%$ of the officers, $7.0 \%$ of the NCOs and $8.1 \%$ of the enlisted soldiers. It is important to note that, contrary to the common idea that female representation is comparatively more limited in the category of officers than among enlisted soldiers, the data show that there is not a great asymmetry between these situations. In Portugal, this distribution was, nevertheless, more asymmetrical, and thus the same values revealed an over-representation in the category of enlisted soldiers (13.4\%) and an under-representation among officers and NCOs (4. $7 \%$ and $4.3 \%$ respectively).

On the other hand, besides being concentrated at the base of the hierarchy, from the point of view of the contractual situation, the presence of women was still relatively insignificant in the permanent structure, where they only constituted $0.8 \%$ of the troops, and much higher than the average (17\%) among non-permanent personnel, that is, among those military professionals fulfilling the Serviço Efectivo Normal (SEN), in the Regime de Voluntariado (RV) and in the Regime de Contrato (RC). The fact of their already representing 11. $3 \%$ of the cadets in training in the military academies suggested, however, that the weight of the female component in the officer's category could come to grow in the following years, as long as there was not a strong tendency to drop out or quit before completion of the course. In this sense, the situation of the Air Force Academy stood out, since $20.6 \%$ of the cadets were women.

To summarise, if we compare Portugal with those countries that have a longer experience of female participation, in spite of the highlighted differences, we find similar patterns in terms of: a) the tendency towards the formal elimination of restrictions of female access to military functions; b) levels of representations that are generally limited, although, in this case, resulting 
from a rapid growth; c) under-representation of women on higher hierarchical levels and in specialties related to the core functions of the armed forces; and d) a clear over-representation in traditionally "female" areas.

\section{Conclusion}

This chapter has explored a series of indicators relevant to situate the Portuguese Armed Forces within the changes which have generally been affecting military forces. This analysis shows the coexistence of features of modernisation and of resistance to change, resulting in a situation which is paradoxical and generator of tensions.

As far as strategic international orientations - such as the perception of threat or the definition of missions - are concerned, the referred postmodern model predicts, on the one hand, a growing loss of the relevance of threats such as invasion or nuclear war initiated by enemy States, corresponding, in terms of priority missions, to the defence of State territorial integrity; on the other hand, it identifies a growing risk of conflicts on a sub-national level (such as public disorder and terrorism) and frequently non-military in the traditional sense, corresponding, in its turn, to the dominance of a new type of mission, designated by acronyms such as OOTW (Operations Other Than War). It has been shown, in the case of Portugal, how both variables reveal some ambivalence, oscillating between the demands of the new international geo-strategic scenario and the prevalence of the previous paradigm centred upon the defence of the territorial integrity of the State. The fact of the new missions having come to acquire more and more salience, however, stands out, in terms of strategic-political discourse, as well as on that of the concrete utilisation of military forces, which clearly situates the Portuguese Armed Forces in the dominant tendency of the new model.

The indicator that unequivocally reinforces this orientation is, nevertheless, the transition towards a system of exclusively voluntary military service, concluded in 2004. While this has happened relatively late if we compare the case of Portugal to that of the majority of countries in the Euro-Atlantic area, it is the result of a process of restructuring of the Portuguese military organization - of an attempt at its adaptation to the new strategic scheme that has been occurring for more than a decade. These adjustments have produced new tensions in their turn. While the transition occurred-size reduction, progressive increase of the voluntary component of contingents, participation in new missions based upon the projection of forces - the Portuguese Armed Forces have seen their budgets reduced, as has happened in most of the Western countries over the past decades.

Likewise, the opening up of military service and careers to women is one of the most relevant aspects of the described change. In a very short time, female representation and gender integration in the Portuguese Armed Forces have 
reached relatively high levels if compared to those of other NATO members, many of which with a much more precocious female military presence. Nevertheless, in spite of the progress done, more than 15 years after the beginning of female recruitment, the tendencies that stood out in the beginning of the integration process remain unchanged, namely those concerning under-representation in combat oriented specialties and within higher hierarchical categories.

Other indicators exist, however, which reveal much less distance from the paradigm of military modernity. This is the case of organisational identification and ethos, as well as professional identities. Although the model of Moskos, Williams and Segal does not offer descriptions or concrete predictions relative to these variables, the changes identified can be viewed in light of the classic "institutional/occupational" dichotomy previously proposed by Moskos to describe the transition between pre-modern armed forces and those of advanced modernity. If the occupational tendency seems to have become dominant in terms of organisational structure, namely regarding aspects such as the reduction of personnel or professionalisation, in other domains, such as the resistance to military unionism, the lack of acceptance of homosexuality (and the tendency to avoid the issue) as well as the relative prevalence of institutional orientations among military professionals - officers and NCOs - a "paleo-modern" model (Battistelli, 1997) of the military organization is still visible.

Finally, regarding the way in which Portuguese public opinion reacted to the organisational transformations under way and the new missions of the armed forces, we observe that, similar to that which has occurred in other countries, the prevision of a relative growth of indifference does not adequately characterise the attitudes of the Portuguese towards their military institution. On the contrary, the traditional ambivalence of public opinion in this domain seems to have given way to an effective, even though possibly temporary, support. We see, specifically, how the Portuguese participation in international missions under NATO and the UN was the object of public approval, contributing to a greater recognition of the role of the military and of the armed forces in Portuguese society.

Approaching the end of the first decade of the $21^{\text {st }}$ century, the Portuguese Armed Forces are, therefore, facing the need of managing tensions resulting from the coexistence of different types of organisational and professional orientations, as well as of responding to the challenges of reforms underway and of those that will inevitably have to be promoted in order to adjust to the progressively globalised conditions in which they must operate. 


\section{References}

Ammendola, Teresa (ed.) (1999), Missione in Bosnia. Le Charateristiche Sociologiche dei Militari Italiani, Milan, Franco Angeli.

Battistelli, Fabrizio (1997), "Peacekeeping and the postmodern soldier", Armed Forces and Society 23 (3), pp. 467-84.

Booth, B., Meyer Kestnbaum, and David R. Segal (2001), “Are Post-Cold War Militaries Post-Modern?" Armed Forces and Society, 27 (3), pp. 319-342.

Buzan, Barry (1991), People, States and Fear. An Agenda for International Security Studies in the Post-Cold War Era, Hertfordshire, Harvester Wheatsheaf.

Callaghan, Jean, and Franz Kernic (eds.) (2003) Armed Forces and International Security. Global Trends and Issues, Munster, LitVerlag.

Carreiras, Helena (1995), "Mulheres nas forças armadas. mudança institucional e recrutamento feminino", Sociologia, Problemas e Práticas, 18, pp. 97-128.

Carreiras, Helena (1997), Mulheres nas Forças Armadas Portuguesas, Lisbon, Cosmos.

Carreiras, Helena (1999), “O que pensam os militares portugueses do peacekeeping?”, Estratégia, 14, pp. 65-95.

Carreiras, Helena (2002a), "Women in the Portuguese Armed Forces: from Visibility to Eclipse", Current Sociology, 50 (5), pp. 687-714.

Carreiras, Helena (2002b), Mulheres em Armas. A Participação Militar Feminina na Europa do Sul, Lisbon, Cosmos and IDN.

Carreiras, Helena (2006), Gender and the Military. Women in the Armed Forces of Western Democracies, London, Routledge.

Carrilho, Maria (1990), As Mulheres e a Defesa Nacional, Lisbon, CCF.

Carrilho, Maria (1994), Democracia e Defesa. Sociedade, Política e Forças Armadas em Portugal, Lisbon, Publicações Dom Quixote.

Carrilho, Maria (1998), Portugal no Contexto Internacional. Opinião Pública, Defesa e Segurança, Lisbon, Edições Cosmos and IDN.

Carrilho, Maria (1999), “Os conflitos nos Balcãs e a redefinição das missões internacionais", Estratégia, 14, pp. 45-64.

Dandeker, Christopher (1994), "New times for the military: some sociological remarks on the changing role and structure of the armed forces of advanced societies", British Journal of Sociology, 45 (4), pp. 637-54.

Dandeker, Christopher (1998), "Les Réponses aux Défis", in Bernard Boëne and Christopher Dandeker (eds.), Les Armées en Europe, Paris, La Découverte, pp. 197-214.

Matos, Luis S., and Mário Bacalhau (2001), As Forças Armadas em Tempo de Mudança. Uma Sondagem à Opinião Pública em Vésperas do Século XXI, Lisbon, Cosmos/IDN.

Matos, Luís Salgado de (2004), “Cheiro a pólvora - da queda do muro de Berlim ao 11 de Setembro (1990-2001)" in Nuno Severiano Teixeira and Manuel Themudo Barata (eds.), Nova História Militar de Portugal, Lisbon, Círculo de Leitores, pp. 232-261.

MDN, Ministério da Defesa Nacional (Ministry of Defence) (1998), A Defesa Nacional e a Profissionalização das Forças Armadas, Lisbon, Ministério da Defesa Nacional. 
MDN, Ministério da Defesa Nacional (Ministry of Defence) (2001), Livro Branco da Defesa Nacional, Lisbon, Ministério da Defesa Nacional.

MDN, Ministério da Defesa Nacional (Ministry of Defence) (2002), Anuário Estatístico da Defesa Nacional 2002, Lisbon, Ministério da Defesa Nacional.

MDN, Ministério da Defesa Nacional (Ministry of Defence) (n. d.), Viver nas Forças Armadas, Lisbon, Ministério da Defesa Nacional.

Moskos, Charles (1977), “From institution to occupation: trends in military organization", Armed Forces and Society 4, pp. 41-50.

Moskos, Charles (1986), "Institutional/occupational trends in the armed forces: an update", Armed Forces and Society, 12(3), pp. 377-82.

Moskos, Charles, and Frank Wood (eds) (1988), The Military, More Than Just a Job, Washington, Pergamon-Brasseys.

Moskos, Charles, Jay Williams, and David R. Segal, (eds.) (2000), The Postmodern Military, New York, Oxford University Press.

Pinto, Luís V. (2002), "Segurança e defesa: a esfera comunitária e a esfera nacional”, Estratégia 16, pp. 179-87.

Santos, Loureiro dos (2001), Segurança e Defesa na Viragem do Milénio, Lisbon, Publicações Europa-América.

Shaw, M. (1991), Post-Military Society. Militarism Demilitarization and War at the End of the Twentieth Century, Cambridge, Polity Press.

Shaw, M. 1998. "The development of 'common-risk' society: a theoretical overview" in Maria Vlachová (ed.), The European Military in Transition, Baden Baden, Nomos Verlagsgesellschaft, pp. 78-80.

Sousa, Teresa de (1999), “A imprensa portuguesa e o conflito na Bósnia: os meses decisivos", Estratégia, 14, 97-103.

Stanley, Sandra, and Mady W. Segal (1988), "Military womens in NATO: an update", Armed Forces and Society, 14 (4), pp. 78-80.

UAL (1998), Janus 98. As Forças Armadas no Novo Contexto Internacional, Lisbon, UAL

Van der Meulen, Jan (2000), "The Netherlands: the final professionalization of the military. ", in Charles Moskos, John A. Williams, and David R. Segal (eds.), The Postmodern Military. Armed Forces After the Cold War, New York, Oxford University Press, pp. 110-120.

Vasconcelos, Álvaro (1999), “A europeização da política de defesa”, Estratégia, 14, pp. 7-19.

Vaz, Nuno Mira (2001), “Um modelo à procura de sustentação”, Nação e Defesa, 98, pp. 49-72.

Vaz, Nuno Mira (2002), Civilinização das Forças Armadas nas Sociedades Demoliberais, Lisbon, Cosmos and IDN.

Williams, J. Allen (2000), "The postmodern military reconsidered”, in Charles Moskos, Jay Williams and David R. Segal (eds.), The Postmodern Military, New York, Oxford University Press, pp. 265-277.

Winslow, Donna, and Jason Dunn (2002), “Women in the Canadian forces: between Legal and social integration", Current Sociology, 50 (5), pp. 641-67. 

Part III INSTITUTIONS, SOCIAL RELATIONS AND REPRESENTATIONS 



\title{
Health and risk in Portuguese society \\ For a new agenda on policies regarding life
}

\author{
Graça Carapinheiro
}

\section{A proposal for a sociological reading of health}

In the very first issue of the journal Sociologia, Problemas e Práticas in 1986, the first sociological reflections on health indicated the beginning of a sociological project subordinated to a constructive and critical model of knowledge that was detaching itself from certain conventional ideas about health research. It was founded on transforming the epistemological basis of the subject health/illness, which was taking place in medicine as well as in sociology (Carapinheiro, 1986).

In the first place, emphasis was laid on the idea of placing the order of health and illness in the order of the world and society, disengaging it from the privatistic relationship with the bio-medical world and displacing the study of specific therapeutic relationships, in particular the doctor/patient relationship, from the central analytical position that it had hitherto held in medical sociology. Thus, a commitment was made to new analytical categories that were discovered by sociological, anthropological and historical research which stressed the variability of the social determinants that, in every age, region of the world and society, define the "diseases", the "patients" and the "states" of health and disease (Herzlich and Pierret, 1984).

One of the analytical categories that emerges from the above is the "social construction of disease". This category involves central questions for the sociology of the development of particular social contexts: the diseases that characterise each society at a given historical time; the typical diseases that came before them; their social distribution; the changes in the position of each of them on the scale of values; the diversity of their social uses; the symbolic production of their representations and the ways they acquire their social status. Another important analytical category is the "social construction of the status of the sick". At first sight, it includes the processes of delineating the social relationships of the patient with the illness, i.e. the social perceptions and 
representations of health and illness that frame a person's particular disease and provide the reference points for establishing his or her particular experiential position; it also includes the subjective and objective resources connected with managing the disease personally, socially and medically. The second approach is based on the working of lay knowledge and its relationship with professional knowledge in various health contexts and, equally, on the fact that the sick person's perspective and his or her independence of medical thought can be affirmed. This approach includes the production of levels of disparity between two statuses of illness: the "illness of the patient" and the "illness of the doctor".

The bases of this particular analytical thesis emerged from the historical, anthropological, philosophical and sociological matter that allowed the first hermeneutic organisation of the most wide-ranging arguments about the nature of health and illness and the phenomenologies that distinguished and separated them from other apparently very close and even related realities and about the dominance of the administrative rationality that underpinned their local and global definition, institutionalisation and management. Thus, the argument regarding the exclusivity of the organicist conception of illness was rejected, the approval of its merely individual and casuistic expression was disputed and the irreducibility of its causes to clinical factors was rebutted. In other words, it was established that the variable configurations assumed when cultural, legal, political, economic, ethical and aesthetic factors are crossed are also a causal factor.

This hermeneutic outlook prompted retrieval of the idea of illness as a total social phenomenon, as proposed by Marcel Mauss (1969). Prominent among all the possible consequences that arose from this option is the idea of mobilising all social structures in the representations of health and illness and, thus, providing for the reception of different conceptions, of which the practical and symbolic universes of social classes, groups and collectives are the backbone. It should be noted, however, that such an option is not to be confused with the acritical acceptance of any conceptual mechanism that demands the consideration of variables that point to the importance of the undifferentiatedly social, to the well moderated atmosphere of the psychic or to the vague fluidity of well-being, as the World Health Organization, which administers the representations of health and illness on a world scale, does with its mechanism.

This same point of view demanded that careful thought be given to the consequences of providing medicine with the power to define the normal and the pathological and, thus, setting it up as one of the main repositories of Cartesian dualist legacies - builders of the history of modernity (Canguilhem, 1991). The 1980s already announced a new scientific agenda for the sociology of health and illness. It regarded the body as an area susceptible to new-phenomenology research and thus, reflexively, mobilised the old assumptions of 
positivist rationalism. It also carefully reviewed the epistemological conditions for maintaining the frontiers that separated human and animal, material and spiritual, and cognitive and sensorial nature from reality. Through the 1990s and up to the present, this agenda has been followed. Moreover, new intellectual challenges have emerged from the experimentation connected with new syndromes, new illnesses, new conditions for living with them and new forms of normativising them. They have driven on the analytical re-assessment of the position of the biological in explaining the social and of medicine's position in contemporary societies with regard to the continuity of its support for the dichotomies: body/spirit; society/biology; human/animal; nature/culture; reason/emotion; rational/irrational; conscious/unconscious; normal/abnormal; and sensual/ascetic (Williams, 2001). In addition, all together, this was the reason why the goals of medical action spread beyond "treatment", "care", "prevention" and "recovery" to include, progressively, "counselling", "guidance", "education", "prevention", "management" and "monitoring".

These were the assumptions that gave rise to a way of practicing sociology that was out of line with the research and intervention methods of medical sociology, or the sociology of medicine, as far as the latter sociologies related to the medical perspective throughout the $20^{\text {th }}$ century. This sociology did not restrict its position, either, to blind agreement with the eminently critical nature of the sociology of health and illness that burst onto the scene in the 1980s. It did, however, consistently establish the controversies, ambiguities and dilemmas aroused by this original disciplinary situation as the subject of permanent reflexivity. In what is stated about the questions that it is proposed to report and examine, albeit briefly, this text seeks to demonstrate these assumptions in relation to new sociological research agendas for health. These not only reveal a wealth of knowledge about health, already consolidated in the Portuguese sociology of the last 20 years but also, principally, related to research completed in the last two years, which gave continuity to this knowledge through innovation and a critical review of the way these assumptions operate.

From the outset, it is necessary to ensure the controlled integration of any health material into the history of the ideas and facts that explain its existence in every society and in the particular social structures that anchor it materially and symbolically. This is the only way to create secure analytical links between health systems, the organisations that make them function, the policies that direct their strategy and the factors that guarantee them the desirable normativity, which is always produced in relation to the situation, according to the eventualities that the local, regional and global scenarios experience (Carapinheiro and Pinto, 1987; Page, 1998; Carapinheiro and Page, 2001).

On the other hand, in the modern and contemporary sense, health is the subject matter for the work of new and old professions. These are tied to professional training processes and models of professionalism which, when 
considered in different organisational contexts, produce health according to different professional practices. These harbour ways of converting knowledge into power and allow the exercise of particular models of professional dominance (Carapinheiro, 1993; Lopes, 2001), reproducing the most far-reaching social strategies for legitimising scientific and technical authority (Carapinheiro and Amâncio, 1993; Amâncio and Carapinheiro, 1993; Carapinheiro and Rodrigues, 1998). Moreover, within the framework of these variables an explanation is found for the forms, in the health sector professions, of internally ranking the methods of associative action, and it is there too that the structural particularities of this sector, already disclosed in earlier studies, are reproduced (Carapinheiro, 2004).

A third platform arises at the meeting point and intersection of these two sociological health-discussion platforms, in the first case as the subject matter of the history of modern times, capitalism and democracy and, in the second, as the subject matter of science and technology and the professions and their strategic activities. It looms transversely over the other two, citing health as a matter of inequality, discrimination and social exclusion $-\mathrm{a}$ matter that is identifiable among professions with unequal positions in the social division of labour in the health area, among professions with the same position, though situated in different careers and organisations, among segments that originated in the same profession by various processes of internal distinction, among professionals and patients and among different kinds of medicine. They can be seen in the way formal and informal kinds of rationale operate and in the exercise of different types of authority, of which the dynamics underlie the mobilisation of countless aspects of professional knowledge and know-how in providing health services. They may be identified in representations about the value of health care and in positions regarding co-ordination between the services producing that care, as well as in the way lay rationale and knowledge operate throughout the patients' social trajectories, undertaken to resolve health problems (Carapinheiro and Hespanha, 1997; Carapinheiro, 2002).

This process gave rise to the idea that we are facing the appearance of various types of social risk that go far beyond the mere risks of disease. This social understanding of risk has disengaged itself from all historically established scientific and administrative conventions that considered, as a risk, the structural relationship between certain conditions of human and social experience and the probability, significantly increased over time, of exposure to the potential effects of contagion by diseases codified as having this property of dissemination, in accordance with controlled circuits of contagion or the uncontrolled forms of an epidemic or, even, pandemic (Rhodes, 1997). Alternatively, social risk is connected with the idea of existing frameworks of uncertainty and eventuality associated with styles and ways of life (Carapinheiro, 2001) and the new scenarios of conflict and change that can 
be seen on a national, supranational and transnational level (Carapinheiro and Côrtes, 2000).

Thus, our passage over the platform of modernity and the institutionalised social forms of producing health that correspond to it, our path across the social contexts of direct health services, immersed in strategic action, and the lay re-creation, overlapping formal creation, of access circuits to health goods, have made it clear that health is a political matter, even when it is not directly tied to political measures and decisions. It is a political matter that is still caught in the epidemiological nexus that envelops the society in its bodies and extracts measurable tangibles from them. Moreover, it has still not recognised the other agenda on policies for life, an agenda caught in the politicisation and re-moralisation of the experience of the emotions, which are experienced in public and private forms. In both cases they are subjected to social mechanisms that link bodies to emotions and to health and illness through complex interpenetrations between existential ways of being, the social activities of being and the social structures that control and appropriate them. It is thus a question of the ontogenesis and sociogenesis of the risks of living, which in the health area are the subject of a particular epistemology (Beck, 1992; Beck, Giddens and Lash, 2000; Gabe, 1995).

With a view to tracing some of the contours of this epistemology, this proposed sociological interpretation suggests a type of relationship between health and society that helps to re-launch the politicisation of health questions, rejecting the privilege given to the individual level of analysis as representing the most appropriate and accessible approach, through frequent use of the notion of individual responsibility and through the hegemony that the idea of autonomy has acquired. This proposal also suggests a type of relationship between medicine and society, outlined in the question of defining the social mandate given to medicine, a mandate determined by the barriers to be placed on its action, by the missions to be entrusted to it and, in summary, by the society that, with it, we wish to have.

\section{Routes of risk in health practices}

In the first sociological investigation in Portugal into infertility and MAR (medically assisted reproduction), it was possible to disengage the social, political, cultural and ethical questions relating to the social construction of infertility and to the production of its deepest social meanings (Augusto, 2004). To achieve this, the author established the necessary critical distance from the notions that represent the status of these situations as "family matters" and from the ideological assumptions that guarantee the social character of their "naturalness". In the search for the main contexts determining the meanings of infertility and MAR, she studied the social representations of maternity and infertility and the values structuring them and analysed the methods of 
making the ideology of biological maternity compatible with that of biological determinism. She also demonstrated that those values and the configurations that these ideologies take on legitimise the medical and social discourse that has been produced on the questions of reproduction. The view of infertility and MAR as a total social phenomenon, together with an analysis of their medicalisation, has intercepted the contributions of the sociology of the body. This has given rise to an analysis that clearly highlights the historical character, the multi-dimensional experience and the cultural complexity of the social and scientific rationalisation of the phenomena of the body and its reproduction. Thus those assumptions have re-emerged that supported the three analytical platforms of sociology, discussed earlier, which gave rise to the specific issues from which the contours of a sociology of risk could be extracted.

The importance that couples give to the risks of infertility treatment and MAR techniques is de-valued by medical discourse, via the reproductive medicine specialists, as it is conceived as an intrinsic part of medical practices and, so, subject to the internal processes of medical and scientific control. For these specialists, the greatest risk, if not the only one, is infertility, which contradicts their value of biological maternity and threatens the reproductive normality of families, in combination with the psychological, emotional and financial risks to which it gives rise. In other words, the bio-medical view of the risk lays importance on the social risk and its sociogenesis, whereas the lay view lays importance on the epidemiological risk and its bio-medical ontogenesis. Moreover, what may at first sight seem paradoxical gains a sociological significance of broader reach when put into perspective in the asymmetrical relationship between unequal levels of knowledge and when set within a wider framework of social inequalities.

In a field as medicalised as this and as difficult from the standpoint of access and interpretation, the lay view mobilizes the norm of biological maternity and the medical norm of risk, socialising them to the nature of the specific social relationships in this medical field, in a process of relative dissociation from the uncertainties and eventualities that weave the objective conditions of their daily lives. The specialists' view mobilises them, too, but, in a process of relative de-medicalisation, politicises them and articulates them with the conflicts and changes in the actual processes of producing medicine. In this duality, the social risks for the couples increase immensely, in proportion to the inequalities of access to treatment opportunities, not only between regions or the state and the market but also between the public services themselves. In the latter case, the inequalities are tangled up in the medical and bureaucratic system that administrates reproductive medicine resources. In contrast to what may be expected of the underlying rationale, it does not regularise them, standardize them or even offer prospective users the same access. On the contrary, a couple's infertility depends on the way the power of medical self-regulation 
functions and on the relationships of strength among specialists: it is managed by services with varying waiting lists and varying criteria for accepting couples, which even violate the geographic order of channelling among services. Finally, given the lack of a legal framework and consensual criteria among the medical community regarding MAR, risk as a non-opportunity increases even more, when compliance with the patient's rights to be treated is subject to a random system of favours and condescension, converting vulnerability into weakness and rights into privileges.

In the case of self-medication the issue of risk seems to take on very different contours... The author of the first sociological investigation in Portugal into the social practices and rationale of self-medication developed an analytical approach to self-medication and its phenomenology, in which she included the aim of unveiling the space of the lay role. This space lies in the changes that have taken place in individual health practices, traced in lay relationships with medicines, the lay solution to health problems and lay contact with specialist systems. Lay perceptions and conceptions of risk were analytically linked to the knowledge put into action in self-medication practices. From this analytical operation emerged the possibility of reconstituting lay reasoning and rationale with regard to the social dissemination of self-medication (Lopes, 2003).

This study brings together the analytical planes outlined in the first part of this text and, as happened with the earlier study, confirms the medicalisation of daily health practices. But it also brought to light their pharmacologisation, in relation to the naturalisation effect of lay contact with medicines and the changeable conditions of their appropriation and mobilisation in order to produce different bodily realities, supported by different body cultures. This research also proved that the routinisation of lay contact with specialist systems, and the reflexivity processes arising from that, gave lay knowledge a vitality that, in concrete terms, could be seen in therapeutic initiatives with greater reconversion and specialisation of the knowledge put into action. Thus, for self-medication, in comparison to MAR, the relationship between lay and expert knowledge is not structured according to the same lines of asymmetry or the same systems of social cognition. This is not equivalent to erasing the structural distance that has been maintained among these types of knowledge throughout the history of modern societies. What exists is expansion and specialisation with regard to the interpretive latitude of lay knowledge about the body, its ailments and its resources for achieving well-being, though with internal systems to grant credibility, which remain indexed to trust in experts.

Thus, the sociological contours of risk that emerge from this study are not indifferent to this differentiation of the structural position of the two types of knowledge and the conceptions and practices structuring them. This is quite clear, since we are dealing with the clever manipulation of medication, as being 
able to contain epidemiological risks, which not only operates in the narrow field of the therapeutic relationships that surround the prescription and consumption of medicines but also seeks to control and oversee lay initiatives for using them outside the orbit of their direct regulation. Let us say that, in the case of self-medication, the bio-medical norm of risk gains importance on the basis of expert knowledge and its material and symbolic effectiveness in eliminating the social risks of its excessive socialisation. However, on their side, lay perceptions of the risk of medication appropriate the bio-medical norm for their symbolic universes, assess their suitability for daily health practices, establish their material effectiveness in solving actual health problems and place value on their social effectiveness by the elimination of the social risks that arise from their excessive medicalisation. The battle between epidemiological risk perceptions and conceptions that understand it as a category of control and those who see it as a category of resistance represents the terms of a particular sociogenesis.

When the risk of disease is inherited, i.e. transmitted or transmissible over generations, and it is possible to identify and prove its genetic components, we are in a risk situation in which the parameters of social reflection are not just restricted to life and death, health and illness, capacities and disabilities, the possession of a genetic inheritance or the functioning of a particular genetic structure, but are also, in particular, centred on kinship. In the words of the author of the first sociological study in Portugal on the genetic risk of hereditary cancer: "(...) When a disease is defined as genetic, we move from an individual to a family disease (...). From this point, what is at issue are the processes and consequences of the interaction of social and biological knowledge in the construction of a perception of hereditary risk and its potential impact on the daily life of the people involved" (Mendes, 2003: 13).

In this particular study, the object of the research is the nature and phenomenology of a specific risk of illness. These two considerations are connected with the experience of living with a new condition - someone who does not yet have the disease or even know when it will manifest itself can be granted patient status. In principle, the people who are subject to this probability, objectively ascertained by the genetic tests available, may respond in various ways, according to the implementation of various reflexively produced strategies for approaching the risk. But, irrespective of the strategy, what unquestionably occurs is the obligation to manage uncertainty and possibility in societies and social contexts marked by times that are obsessed with certainty and control: in both cases they mobilise resources which have a trust in science and its double, technology, at their source. In identifying the problem of the possible forms of social action regarding genetic risks, the author dealt with acceptance and co-operation as well as their negative counterparts, rejection and resistance. She did so, however, by questioning the strategic position held by genetics and molecular biology, not only in the construction of new 
medical categories linked to our knowledge of new disorders and new individual susceptibilities to disease, but also on account of the social implications of this knowledge in imposing preventive practices. Moreover, if we consider the applications already tested in other places on the basis of a knowledge of the human genome, these practices will tend to take on a progressively coercive nature. Such a huge task belongs to the age of genetic and preventive bio-politics of the future, to which the transition is already foreshadowed in the present.

This case deals with the genetic risk of hereditary cancer: the symbolic play of the perception of this risk combines the symbolic effects of carrying this particular kind of risk with the symbolic effects of being a cancer risk, with its web of individual, family and social meanings expanding and becoming denser around the fear. Those who are subject to this experience of fear live it in a unique manner as, in contrast to what might be expected, hereditary cancer has greater visibility than cancer that is not. This is because its existence is announced and, thus, demands an individual and social consciousness of its inescapable curse, reflected in the experience of new ways of existing that, henceforth, as a potential threat or a reality, can never drive it from the framework that organises the reflexive choice of the options of those involved. As the author of this study mentions, this is not a paralysing fear but one that galvanises (Mendes, 2003: 330) - hence the sociological relevance acquired in this research by time, either when seen as experience or as a representation: different ways of managing time emerge, as its representation takes the form of redemption, "acting in time", the form of blame, "acting against time" and the form of hope, "acting in the expectation of time" which a future medicine of the "future" has to achieve.

In contrast to earlier studies, this one problematises the risk by involving it with a so-called "endogenous conception of illness", in which, however, the "endogenous" property is withdrawn from its strictly bio-medical wrapping and divested of its epidemiological nature, to be reformulated in terms of family inheritance and heritage, genetic lines and existential legacies, yet to be fulfilled. Furthermore, this type of risk is carried from every past to be able to take revenge in every present and, therefore, in every age the dice of family histories are in play in the personal histories of individual decision-making, involving complex processes of the composition and re-composition of identity. And even if we recognise that the knowledge of these individuals is being increasingly developed through various means of integrating medical and genetic knowledge, according to their social positions and the opportunities arising from access to different sources of information and knowledge, we do not find here the same equations between lay and expert knowledge that maintained the systems of risk analysed above, nor the same position of the biological order in the social order. There are variations in the understanding of risk as an opportunity and as a fatality, though they are 
subordinated to increased specialist confidence and subject to the symbolic force of belief in the Promethean vision of science.

Another possible sociological approach to a specific risk-producing system was provided by the investigation carried out into medical technocracies with regard to the power strategies generated around liver transplantation in hospitals (Serra, 2003). Through the careful ethnography of a transplant unit, the author disclosed a sociological object involving a tangle of profoundly interwoven situations, around the clinical processes of transplantation, the professions and specialisations involved in them and the diversity of actors present, who were framed within the history of the transplant and the delicate management of organ donation, delineating the spaces where the critical factors of fading life and imminent death crossed over.

Anchored in the centre of medical power/knowledge, this research examined the technologies put into operation with a view to constructing medical technocracies, on the basis of their scientific and technical content, their activities, their procedural co-ordination and their appropriation by different medical specialities. But what gave this movement significance and meaning is the risk in its own creation, since the possibilities of the emergence of medical technocracies are tied to the uncertain, indeterminate and contingential nature of medical knowledge and permanently turn into areas of relationships and social practices where knowledge, technology, experiences, aptitudes and skills are negotiated. As they are movable power systems, when they are effectively established they correspond to the most organised and structured expression - attained within a certain framework of organisation variables - of all the formal and informal processes of converting this knowledge into power. But technocracies may appear and be consolidated, may appear and vanish or, often, not even achieve organisational viability and may see the opportunity of their appearance fade away, as this all takes place in accordance with numerous constraints that are difficult to foresee. In hospital organisation, high tech does not automatically mean greater institutionality of its functional configurations. It means very high operation levels of the informal structure and a high production density of informal relationships, that is, of all the kinds of knowledge with their objects, of the specializations with their knowledge and of the participants with their strategies, supported by this knowledge.

The system of risk production emerging from these processes links bio-medical risk (in the clinical phenomenology of transplantation and the management of the vulnerable frontier between the opportunity of living and the certainty of dying, largely deriving from it) to the risk connected with the nature of the medical knowledge mobilised (of the internal order of this knowledge, its hierarchical and stratification system, its production and dissemination system and its system of authority and power over all the other professional and lay forms of knowledge). And as this is its system, 
inequality, discrimination and exclusion are connected with it: though they do not convert it into a conventionally epidemiological risk, they transform it into a polysemic social risk, from which the patient does not become ill but suffers - from the lack of autonomy, the absence of participation, the limitation of rights and the cultural rejection.

The analytical review of the various risk systems, carried out in the course of this text, point to a conclusion that, though not yet possessing sufficient empirical validation, has already marked a fairly significant presence in health matters that have been sociologically investigated. It seems possible to speak of movements that medicalise risk while allowing variable conditions for the appearance of movements that socialise this same risk. Let us see. In the first study, the socialisation of risk seems to be confused with its privatization, in the case of couples, and with its politicisation, in the case of specialists. In the second study, the socialisation of risk involves the pharmacologization of health practices and remains heavily dependent on them. In the case of the study of genetic risk, it is possible to give an idea of the reach that its establishment acquires in times of increasingly geneticized family histories. Moreover, when we question the setting-up of medical technocracies in the organisation of hospitals, what seems to acquire greater relevance is the importance of the diversity of professional cultures, like bio-medical cultures, for their participation in the control processes of the most difficult and critical risks. In fact, it seems that the closer we come to the institutional contexts of health, the more the socially selective character of the bio-medical discourse on risk is reinforced and the more we approach the daily contexts of health practices, the more the bio-medical character of the social discourse on risk is stressed, in reciprocal processes of the endogenisation of cultures. Will the medicalisation and socialisation of risk be two movements, in opposite directions, of social risk-management or will they only correspond to the expansion of medicalisation to ever wider social circles?

\section{References}

Amâncio, Lígia, and Carapinheiro, Graça (1993), Dominância, Poder e Saber. Formas de legitimação da autoridade científica e técnica na sociedade portuguesa (research report), Lisbon, CIES.

Augusto, Amélia (2004), Infertilidade e Reprodução Medicamente Assistida. Dos problemas privados aos assuntos públicos (PhD thesis in sociology), Covilhã, Portugal, Universidade da Beira Interior.

Baszanger, Isabelle, Bungener Martine and Paillet Anne (eds.) (2002), Quelle médecine voulons-nous?, Paris, La Dispute/SNÉDIT.

Bauman, Zygmunt (1998), Globalization. The Human Consequences, London, Polity Press. Bauman, Zygmunt (2001), Modernidade Líquida, Rio de Janeiro, Jorge Zahar Editor. Beck, Ulrich (1992), Risk Society, London, Sage. 
Ulrich, Beck, Giddens Anthony and Lasch Scott (2000), Modernização Reflexiva, Oeiras, Portugal, Celta Editora .

Canguilhem, Georges (1991), Le Normal et le Pathologique, Paris, PUF.

Carapinheiro, Graça (1986), "A saúde no contexto da sociologia", Sociologia, Problemas e Práticas, 1, pp. 9-22.

Carapinheiro, Graça (1993, 1995), Saberes e Poderes no Hospital. Uma sociologia dos serviços hospitalares, $3^{\text {rd }}$ edition, Oporto, Edições Afrontamento.

Carapinheiro, Graça (2000), “Depoimento” in AA. VV., A Saúde em Debate, Lisbon, INCM, pp. 103-111.

Carapinheiro, Graça (2001), "Globalização do Risco Social" in Boaventura de Sousa Santos (ed.), Globalização. Fatalidade ou Utopia?, Oporto, Edições Afrontamento, pp. 197-229.

Carapinheiro, Graça (2002), “Inventar percursos, reinventar realidades: doentes, trajectórias sociais e racionalidades formais", Revista Etnográfica, V (2), pp. 335-357.

Carapinheiro, Graça (2004), "O sector da saúde: formas de hierarquização interna" in Freire João (ed.), Associações Profissionais em Portugal, Oeiras, Portugal, Editora Celta Editora, pp. 57-82.

Carapinheiro, Graça, and Lígia Amâncio (1993), “A vã glória de mandar, estratégias de legitimação da autoridade científica e técnica", in Actas do II Congresso Português de Sociologia, Lisbon, Fragmentos.

Carapinheiro, Graça, and Margarida Gameiro Pinto (1987), “Políticas de saúde num país em mudança: Portugal nos anos 70 e 80", Sociologia, Problemas e Práticas, 3, pp. 73-111.

Carapinheiro, Graça, and Maria de Lurdes Rodrigues (1998), “Profissões: protagonismos e estratégias" in José Manuel Viegas and António Firmino da Costa (eds.), Portugal, que Modernidade?, Oeiras, Portugal, Editora Celta, pp. 147-164.

Carapinheiro, Graça, and Maria José Hespanha (1997), A Articulação Entre Cuidados Primários E Cuidados Hospitalares. Uma Análise Sociológica (research report), Coimbra, Portugal, CES.

Carapinheiro, Graça, and Paula Page (2001), "As determinantes globais do sistema de saúde português" in Pedro Hespanha and Graça Carapinheiro (eds.), Risco Social e Incerteza. Pode o Estado Social Recuar Mais?, Oporto, Edições Afrontamento, pp. 81-121.

Carapinheiro, Graça, and Soraya Côrtes (2000), “Conflitualidade e mudança face a novos cenários globais: o caso dos sistemas de saúde português e brasileiro", Revista Crítica de Ciências Sociais, 57/58, pp. 259-290.

Douglas, Mary (1992), Risk and Blame. Essays in Cultural Theory, London, Routledge. Fox, Nicholas Jay (1999), Beyond Health. Postmodernism and Embodiment, London, Free Association Books.

Gabe, Jonathan (ed.) (1995), Medicine, Health and Risk. Sociological Approaches, Oxford, Blackwell Publishers.

Herzlich, Claudine, and Janine Pierret (1984), Malades d'Hier, Malades d'Aujourd'hui. De la Mort Collective au Devoir de Guérison, Paris, Payot. 
Hespanha, Pedro, and Graça Carapinheiro (eds.), (2001), Risco Social e Incerteza. Pode o Estado Social Recuar Mais?, Oporto, Afrontamento.

Le Breton, David (1990), Anthropologie du Corps et Modernité, Paris, Quadrige, PUF.

Le Breton, David (2002), Conduites à Risque, Paris, Quadrige, PUF.

Lopes, Noémia (2001), Recomposição Profissional da Enfermagem. Estudo Sociológico em Contexto Hospitalar, Coimbra, Portugal, Quarteto.

Lopes, Noémia (2003), Automedicação. Práticas e Racionalidades Sociais, PhD thesis in sociology, Lisbon, ISCTE.

Lupton, Deborah (1994), Medicine as Culture. Illness, Disease And The Body In Western Societies, London, Sage Publications.

Lupton, Deborah (1998), The Emotional Self. A Sociocultural Exploration, London, Sage.

Lupton, Deborah (ed.) (1999), Risk and Sociocultural Theory. New Directions And Perspectives, Cambridge, Cambridge University Press.

Mauss, Marcel (1969), Oeuvres, vol. 3, Paris, Éditions Minuit.

Mendes, Felismina (2003), A Herança dos Mal Nascidos. Um Estudo De Caso Sobre O Risco Genético De Cancro Hereditário, PhD thesis in sociology, Lisbon, ISCTE.

Page, Paula (1998), Políticas de Saúde Portuguesas 1940-1990. Consolidação De Um Novo Regime de Poder entre a Intenção da Mudança e os Limites da Continuidade (Master's degree thesis in sociology), Coimbra, Portugal, Faculdade de Economia da Universidade de Coimbra.

Peterson, Alan, and Deborah Lupton (1996), The New Public Health. Health and Self in the Age of Risk, London, Sage Publications.

Radley, Alan (ed.) (1993), Worlds of Illness, London and New York, Routledge.

Rhodes, Theodore (1997), "Risk theory in epidemic times: sex, drugs and the organization of risk behaviour", Sociology of Health and Illness, 19 (2), pp. 208-227.

Scambler, Graham, and Paul Higgs (1998), Modernity, Medicine and Health. Medical Sociology Towards 2000, London, Routledge.

Serra, Helena (2003), A Construção Social de Tecnocracias Médicas. O Olhar da Sociologia no Mundo da Transplantação Hepática, PhD thesis in economic sociology and the sociology of organisations, Lisbon, ISEG, Universidade Técnica de Lisboa.

Smart, Barry, (1999), Facing Modernity. Ambivalence, Reflexivity and Morality, London, Sage.

Swaan, Abraham de (1990), The Management of Normality. Critical Essays in Health and Welfare, London, Routledge.

Turner, Bryan S. (1992), Regulating Bodies, Essays in Medical Sociology, London, Routledge.

Williams, Simon J. and Michael Calnan (eds.) (1996), Modern Medicine. Lay perspectives and experiences, London, UCL Press.

Williams, Simon J. (1998), “Health as moral performance: ritual, transgression and taboo", Health: An Interdisciplinary Journal for the Social Study of Health, Illness and Medicine, 2 (4), pp. 435-457.

Williams, Simon J. (2001), Emotion and Social Theory, London, Sage Publications. 



\title{
Penitentiary risk and prohibitionist spirit
}

\author{
António Pedro Dores
}

(...) He who looks upon the splendour of the world is logically destined to look upon the astonishing suffering of the world (...)

[Sophia de Mello Breyner Andresen]

In Europe, Portugal is at the top when we refer to perverse penitentiary indicators. Although Portugal possesses one of the lowest crime rates in the European Union, the country imprisons an amount of detainees that, in Europe, is among the highest. This is due in part to the influence of the North American correctional policy, which incarcerates two million prisoners and detains more than five million people with judicially limited rights. Other contributing factors to Portugal's relative supremacy in this area are the particular characteristics of the Portuguese judicial process, slow and formalist. ${ }^{1}$ It is estimated that at least half of the prisoners in Portugal use "drugs" in jail ${ }^{2}$ and around three quarters are in prison for reasons that are either directly or indirectly related with the trafficking of illegal narcotics (cf. Costa, 2003).

Since the beginning of the 1980s, the globally developed drug trafficking networks have found an entrance point into Europe through the Portuguese maritime coast and the difficulties of this coast's vigilance. The increase in the number of prisoners since then has owed itself to the so-called "war against drugs", instigated on the international level by the United States administration through the United Nations (Woodiwiss, 1998). Towards this aim, a commitment has been made to the local application of judicial process laws which are especially punitive in this type of case, as well as to the intensifying of penalties for drug trafficking convictions, even if some softening changes has been approved recently (Costa, 2003).

1 For the characterisation of the Portuguese judicial system in general, see Santos.

2 Estimates released by the European Council in 2001 point to values between $40 \%$ and $80 \%$ of consumers in the Portuguese prisons. 
Can Europe, and Portugal in particular, come to develop a penitentiary system in proportion to that which is present today in the United States (with relative rates of incarceration eight times higher than the current average of the Union), or will the development of the European social model dispense with such a procedure? Is it the recently adopted downsising prison population policy in Portugal becoming a European trend or will it be the reverse, as it happens in Spain, UK and other European Countries, to prevail?

\section{Penal society and information society}

Loïc Wacquant has been distinguished in the beginning of this new millennium by his analysis of what he calls the Penal State. He declares this new configuration of the State to be a practical consequence of the application of the neo-liberal ideology on the other side of the Atlantic, a process which is more commonly known in Portugal by the slogan "less State and better State". With the expression Penal State, the author refers to the fact that the freedom of the market should be protected not by equality of opportunities within the markets or by social justice from outside the markets, as in the Social State, but rather through the social exclusion of the excluded, shall we say, as a dominant government strategy for social insecurity. ${ }^{3}$ The turbulence of the employment markets, and in particular the vacuuming up of the social outcasts to which Wacquant refers, functions together with the exploitation of the work capacities of those who are socially included, and at costs which are competitive with the unregulated employment markets of the Third World. The information society, in this hard version, would be defended from the info-excluded society by a system for managing the excluded; that is, the masses, the abnormal, the alienated, the nomads, the colonised, the foreign, the negroes, and all those who might be stigmatised. In short, this includes all those who do not establish flexible and competitive social networks for the precariously available work (Workfare State). ${ }^{4}$

Profitable society is composed partially of routine workers, as Reich (1991) calls them (disciplined and afraid of the spectre of unemployment and the respective social exclusion), and partially of the middle class, whose main responsibility is to classify, for better or worse, all products, all processes and all socio-economic entities. ${ }^{5}$ Reich calls these symbolic analysts. They are basically proto-consumers of classification, to use Toffler's (1980) term. The

3 Regarding the alternation between inclusive and exclusive society, see Young (1999).

4 We refer here to Löic Wacquant's conference, "Les Scories de l'Amerique: Toxicomanes, Malades Mentaux et Sans-Abris" of 7 June 2005, Anthropology Colloquium "A Prisão, a Psiquiatria e a Rua (Prison, Psychiatry and the Street)" Manuela Ivone Cunha and Cristiana Barros (ed.), Instituto de Ciências Sociais (ed.), Lisbon.

5 Regarding the classifying information society, see Lyon (2001). 
info-literates train themselves in the use of the practical rules of systematic classification adopted by the professions in which they have been trained and, towards this aim, they must ignore all the noise. They develop a lack of strategic curiosity and competence, which is continually incorporated so as to annul natural curiosity in the face of any non-professional information, and which always requires a specialised effort of initiation to be understood. ${ }^{6}$

Professional and organisational network specialisation (Reich, 1991, Castels, 2004 and Cardoso et al., 2005) is one of the latest steps in the secular process of modern individualisation, one practical result of which is a reorganisation of the dominant social relationships. Such reorganisation occurs without any pre-established plan, and therefore is expressed locally in a particular form, according to the practical effects followed by the intentionalities who conduct them. ${ }^{7}$

On the global level, "scientific" elaborations of socially manipulative systems of intentionalities are detectable, expressed by the activity of think-tanks as described by Wacquant (2000). They speak of science in order to sell security consultation services internationally: for example, "zero tolerance" policing activities, or private military services, which have become particularly prosperous in the second war against Iraq.

The members of the classifying middle class of symbolic analysts (who generally work in offices) can adopt unreal visions of the world, whether personal or professional. Symbolic abstraction and the processes of social decontextualisation allows for simulation, but does not so easily allow for the test of reality. The scientific tension, shall we call it, which takes possession of the professionals, concentrated upon their specialised projects and alienated from the practical results of their work, helped by the social tension of emerging inequality, tends to bring about the personal desire for fusion, not in the sense of the proletariats but with the profession and its manipulable classifications. $^{8}$

Cases such as that of Eron or of the Anglo-American system of international industrial espionage, investigated by the European Parliament, show how the legitimate and adequate use of information and communication technology is linked to its illegitimate usage, making it possible for the many symbolic analysts of the middle class to not be able to understand the practical results of their professional and institutional activities, or the intentions of the organisational and institutional processes with which they collaborate.

Castels (2004) refers to the way in which Finland has been turned into an information society with drastic diminution of recourse to the penal system, confirming in this dominion the collective and popular desire of the approaching of other Nordic countries, after the abandoning of the Soviet Bloc (which has been characterised by high rates of incarceration).

8 The growing need for higher professional training in western societies supports, accompanies and is a consequence of these tendencies towards fusion among the worker of the symbolic and his profession, in the sense of a radicalization of the individualization which is reflected in the reconstitution of social classes, cf. Costa et al. (2000). Regarding 
Outside of professional life, intensely lived around the prefabricated and authorised classifications, tacitly built into the orders that arrive by computer, following the rules which are presented daily to the point of exhaustion by the computer specialists of the "systems" (meta-level of the division of labour that reorganises the division of labour itself in real time), the members of the middle class reproduce (as a defence tactic) the dominant ideology incorporated in the designs of the organisation where they work. ${ }^{9}$

As investigators know especially well, whenever reality does not conform to the theories being used, the tendency to conform reality by force may emerge, avoiding the professional risk of looking for a new substitutive theory. In the same way, insecurity and fear emerge naturally whenever society ceases to correspond to our expectations. To conform society to these expectations, at least symbolically - which can be a ritual directed by institutional and protective powers - is a common strategy to achieve the benefit of a renewed feeling of confidence/security, even if this is obviously illusionary or only momentary.

Wacquant says that the current social insecurity results from being politically incorrect, such that the politicians promise jobs or social security - promises that, according to neo-liberalism, will only have the result of aggravating the public deficit. The political return of the promise of security (in the streets, it should be understood) is more likely, a promise which can easily be exploited through the provocation of the phenomena of moral panic. ${ }^{10}$ As a bonus, security policies pay dividends through the pressure that they exercise, downwards, upon labour costs. ${ }^{11}$ Social insecurity results from a way of life which is progressively solitary, reflexive and professional, intensely urban and global, and which feels accelerated and stressful, always unsatisfying. We become susceptible to processes of blaming ourselves for our incompetence or even for our competitive inability, in a virtual world delineated by constantly insufficient classifications, to which reality will never be conformed, as it is supposed to be, finally, in the information society! $!^{12}$

From top to bottom, the persistent policy of the reduction of labour costs, whether through the intensive use of new information and communication technology, or through that of the political demobilisation of a significant part

the place of the concept of intentions within the framework of the theory of stigma read Dores (2001).

9 Regarding this aspect and, in particular, the functioning of fixed classifications and the class-conscious patters of taste, see Bourdieu (2001).

10 Regarding the socio-political possibilities of the manipulation of moral panic, see Dores (2005a) and Woodiwiss (1988).

11 Chaves (1999) shows how the classes in the process of exclusion are divided among those who are resigned to poorly paid, routine work and those who take risks.

12 Politics turns increasingly to science as a way to legitimise its decisions. For a discussion of this topic, see Eduarda Gonçalves (2000). 
(the ever larger part) of society and of humanity, results from strategies of capitalistic exploitation, consciously and internationally interrelated..$^{13}$

The North American example and the analysis of Wacquant show that the penal society functions with the information society. Will the penal society be a logical consequence of the information society? The answer is negative, as Castels shows (2004), using the Finnish example. The question must therefore be reformulated: what gives rise to a penal society, according to the historic conditions of an information society? Will it be the collective conscience that especially values the threatened social cohesion? Will it be the political and ideological liberties that enjoy the spirit of capitalism, winner of the Cold War? Will it be the historic leading tendency of the revolutionary neo-liberal class, enthusiastic about the new perspectives that arise?

The answer that we give here is more prosaic: if the prohibition-oriented frame of mind is not rationally understood and, on the contrary, if it is used as one of the principle means of harmonisation among humans, their institutions and their leading groups, then vicious cycles will be produced from among the violent irrational reactions, legal or otherwise, allegedly defensive, and the feelings of ancestral and bio-genetically inscribed security will thus be hedonistically satisfied.

\section{Penal, technological and privatised policies}

The criminal and penitentiary themes are "objectively" recounted on the interior pages, in the society sections of the reference journals, as in the $19^{\text {th }}$ century. ${ }^{14}$ They are also presented as spectacles, on the front pages of the tabloids. ${ }^{15}$ This contrast establishes proof of the opposability of the frames of mind of the consumers of different publications. On the popular side, there is the participatory dissection of each case, as an emotionally intense, rationally carefree, daily and experiential activity. On the side of the symbolic-analysts, there is the voyeuristic distancing from the danger of contamination by socially stigmatised experiences. Each of these, in their own way, attempts to exorcise the risks in a downward direction, emphatically demanding the

13 The author of Le Nouvel Esprit du Capitalisme applies himself to these mechanisms, centered upon the French reality, proposing a renovation of the study of the classic intuition of Max Weber. Cf. Boltanksky and Chiapello (1999).

14 The study by Maria João Vaz, integrated in the investigation project "Prisão de Não Nacionais" (Prison of Foreigners) conducted in CIES-ISCTE under the coordination of the author, refers to the way the police and prisoner records were exploited as a source of news, opposed to the political opinion, in the emerging period of modern journalism in Portugal.

15 In Portugal, the 1995 electoral campaign was won by the left with a speech politically justifying the combat of the risks posed by radical right tendencies (eventually inspired in Le Pen). Cf. Roberts and Hough (2002) about the Anglo-Saxon world. 
police and courts to perform actions that they would not want for themselves. This is done specifically so as to delineate, symbolically, a defensive distance, like a person who, when shipwrecked, steps on the body of his rescuer, trying in vain to create a solid ground from him upon which to walk. In practice, it can be seen, systematically, that when one persists in the demand for justice, the persistence is as ephemeral as the scandal and the revolt. ${ }^{16}$ This is true, except when the political regime itself is under scrutiny. ${ }^{17}$ As long as this does not occur, the judicial system, independent and in solidarity with the regime, is maintained as an unquestioned institutional pillar, more or less despotic, more or less respected.

The success of Loïc Wacquant's structural analysis of the emergence of the Penal State contrasts, in its scientific rationality, with the political success of the promoters of social panic for electoral and ideological ends, an action which the author denounces precisely for its claiming false scientific credits. ${ }^{18}$ Such a contrast is a reflex of the social contradictions between two ways of understanding social organisation, which is expressed politically by the opposition between the Worldwide Economic and Social Realms. The ruling class and the professional scientific class confront each other with contradictory agendas for the mobilisation of financial, institutional and cognitive resources, and these groups can be classified as prohibitionists and non-prohibitionists.

The integrated systems, those of flexible management user friendly real time systems, whether for purposes of internal or international security (which are progressively more mixed together) are more universal (that is, applicable to any social context) the more they are supported by primary human emotions. There is comparatively more cost and political compromise involved with the following groups: observatories; international networks of Non-Governmental Organizations connected to agencies; international organisations of socio-economic, political or environmental regulation; and universities/businesses of services rendered to order (that is, through long and complex processes of contextualisation).

16 Many abused women avoid revealing their humiliation. Likewise, prisoners, once freed, do not officially complain about the illegal actions which they had witnessed and of which they had eventually been victims in the name of the Law. The same resignation characterises those who create a throng outside the door of the courts during a shocking case, only to disappear again from the public space, with the same speed and anonymity with which they appeared.

Since the taking of the Bastille, we have been able to verify that revolutions become manifest practically and symbolically in the release of prisoners from jails.

18 The same type of debate over scientific credentials occurs in the environmental field, between those who believe the cause-effect relationship between $\mathrm{CO} 2$ emissions and climactic changes to have been proven, and those who believe the opposite to be true. The exploitation of the social value of science has not been historically inaugurated in this case; all of the modern regimes have used this approach, including during the Second World War and after the Cold War. 
The exportation of incarceration technology is used to homogenize the applied social contexts. ${ }^{19}$ The computerised models of policing management (such as those which have made New York a successfully police case study) which Wacquant (2000) evaluates are examples of technological proposals; that is, they are applicable independent of and indifferent to the socio-institutional conditions of intervention, and the diagnoses which can be given about these conditions.

The adoption of such de-contextualised technologies has de-contextualising consequences, namely those of the marginalising, and even the concealing, of social diagnoses, as well as of the institutional agents and of public opinion. ${ }^{20}$ The act of attending to the identified problem ceases to be a priority. Instead, the focus is placed upon the installation and management of technology. ${ }^{21}$

The de-contextualising effects are continued on the level of the privatised-public financial engineers who feed the controversial investments in the heart of the State..$^{22}$ In Portugal, according to Brito (2004), the average annual cost of each detainee is approximately 23,000 Euros, compared to 11,200 Pounds in the United Kingdom and 22,000 Dollars in the United States, according to information provided by Pat Carson and Loïc Wacquant, ${ }^{23}$ respectively. In spite of ambiguities which have reached the public, the political intent to construct another high-security prison in Lisbon has motivated the mobilisation of private capital, according to the proposals which were developed during the governmental rule of different parties. The relevant counterparts will necessarily be in agreement, but the exact details of these proposals are unknown. Similarly, the experiment of a partnership with a Catholic institution - the "Misericórdia" (Compassion) of a northern city where a new management experiment takes place - to test the consequences of the delivery of

19 The Model F of isolation is being contested in Turkey, whose westernised government has encountered consecutive three year hunger strikes and dozens of deaths. The white prisons, used by the U.S. A, preface, architecturally, the opening of discussions about the "right of the enemy" and about admissible levels of torture. The privatisation of prisons has allowed for the development of a private world wide industry which involves competition and exportation.

20 In Portugal, there was a political intent to produce an "electronic bracelet" indicator, as soon as it reached the experimental phase: in 2003, the registry listed 145.

21 See a description of penal policies in Portugal since the 1990s in Dores 2004, including the strategies of technological attention dispersion, with electronic bracelets or with high-security prisons.

22 To the eyes of some, this reveals the radical political intent of the delivery of the Legal State to the market.

23 Carson, Pat, "Women in Prison" and Wacquant, Loï, "Les Scories de 1'Amerique: Toxicomanes, Malades Mentaux et Sans-Abris" in the Anthropology Colloquium " $A$ Prisão, a Psiquiatria e a Rua (Prison, Psychiatry and the Street)" organized by ICS, Cristiana Bastos (U. Lisboa) and Manuela Ivone Cunha (U. Minho), 6-7 June 2005, Lisbon, ICS. 
the management of a prison to private hands began by being publicly presented as a result of the recommendations that prisons should be open and transparent to non-governmental agencies. In the end, this act was recognised as a proto-experiment of privatisation. ${ }^{24}$

Symbolically, it was in Monsanto-Lisbon, on the grounds of a old prison, where the foundation of the new high-security prison was began, that the Secretary of Law Celeste Cardona was directed to the public address system to announce the "humane" conclusion of prison reform, promoted by Freitas do Amaral (the current Secretary of Foreign Business of a central leftist government), then president of a governmental initiative mission for prison reform. In spite of the secretary's declarations of agreement, the ideological observation was a showy but subliminal message, revealing at the same time the practical consensus of the different dominant sensibilities (political right and left, humanist and tough on crime sensitivities) and the delicacy, the seriousness and the difficulty of that which was involved.

It is possible to expect a knowledge society to emerge from the information society? If the generalised ontological insecurity, although uneven, is channelled politically for positive and rational therapeutic ends, instead of irresponsible politico-economic usage, the answer can be "yes". If the insecurity is a pretext to justify the primary obsession of capitalist investments, politically legitimised by the blackmail of the enacted moral panic, independent of the relevant problems and social justice, the social division will probably increase between those who benefit from it, those who are superfluous and those who serve the primary figures and are inconvenienced by the secondary ones.

It falls upon the field of sociology to produce information not only about the practical risks of the dominant social configuration turned Penal State, but also about the diagnostics that point to therapeutic ways of confronting these risks, being simultaneously able to avoid the Penal State and the susceptibility to the political activities concealing the causes of poor quality societal life. Along with there being a critical science in this historic phase of radical social transformation, it will also be useful, as in the Durkheim proposal, for there to be a science of ethics adapted to current problems. Another possibility, as Max Weber has shown us, is that beyond the spontaneous emergence of the institutionalised technologies of social production, we should consider the existence of a structural machine radically embodied by a certain category of people-in this case, the spirit of capitalism - which has the ability to diffuse like an oil slick and can have intimate and individual or familiar expression. Marx also

24 "The perspective of privatisation now arises, and it is not yet known what this is, how it will be, and what is occurring behind the scenes", from the editorial in Voz das Misericórdias, August/September 2004 which announces the "privatised-public shared management" in which it collaborates. 
called our attention to the necessary character of the revolutionary spirit, socially anchored in interests, in order to give continuity to social revolutions, whether they be proletarian or neo-liberal. In other words, daily practices were, and are, more than this, given that history is written by them, even if in an uneven and structured form. Is this not one of the great lessons of sociology?

\section{Social problems and social justice}

Has the chronic overpopulation of jails, which also occurs in Portugal, ${ }^{25}$ contributed to resolve or moderate the problems of insecurity, or to dissuade the drug traffickers, the paedophiles or the corrupt, for example? Furthermore, will it be able to ultimately contribute to such ends? The rational answer is opposed to the prohibitionist answer.

Cunha (2002) notes how the main woman's prison in Portugal has transformed, during the decade of the 1990s, into a space of strong social relations, previously inexistent, for the drug traffickers/consumers from the popular neighbourhoods that, within the prison, maintain community relations based upon this new condition. In practice, the war on drugs through prohibition has created a mercantile focus in the heart of the penal judicial institutions, as we have seen above, disorganised and evidently incapable of making the Law respected or obeyed. ${ }^{26}$ On the contrary, the Portuguese state decided, in the end of the 1990s, to create a public Institute for the collection of information, and to debate and propose social policies in order to confront the consequences of illegal drug abuse. The European Parliament, conscious of the recurrence of results in all the European states subjected to the international prohibitionist policy, approved, in the end of 2004, an anti-prohibitionist recommendation..$^{27}$

The density of incarceration in Portugal was 119 in 2001; source: European Council, Space 2001: 12.

26 When in 1996 the government at the time reacted to the denunciation of the Portuguese Ombudsman with a program of investments, it did not caution the mobilisation of organisational recourses necessary for the achievement of the declared ends, and made possible the waste which lasted for two years and ended with judicial accusations against the General Director. Cf. audit report no. 6/2000 of the Tribunal de Contas (Court of Audits).

27 "Approved (on 15 December 2004) by the European Parliament, the Recommendation to the European Commission regarding the European Strategy of the Fight against Drugs for the period 2005-2112. (...) The recommendation clearly affirms that (...) 1 . The drug strategy has, so far, been a failure; 2 . None of the great objectives of the previous European Strategies have shown positive results; 3 . It's necessary to evaluate the social and economic costs, and the costs to public health and to the personal health of the drug users, as well as to evaluate the impact upon the quality of our democracy and the lack of respect for human rights; 4 . The reduction of risks and the minimisation of damages has to be the engine behind the drug policy; 5 . It's necessary to promote scientific investigation into the positive use of cannabis, the cocaine leaf and narcotics; 6 . A greater and more concerted involvement of the civil society organisations is indispensable (...)" in Luís Mendão, "Boas Notícias 
In practice, the prohibitionist spirit prevails and causes waste in the jails, but also on the judicial level, regarding which we will not speak here. ${ }^{28}$ In the street, namely in Lisbon, if the problems don't worsen (Casal Ventoso was destroyed for dismantling the largest drug supermarket in Europe), they disperse. The transfer en masse of the drug environment to the area of the city called "Intendente" has been a public spectacle, turning the traditional prostitution zone into an outdoor dumping ground. On the worldwide political level, the question is one of the problems, on par with the more recent theme of terrorism, regarding which only prohibitionist policies are admitted for consideration. This confers symbolic value relevant to the declaration of the European Parliament, but adds doubts about its immediate practical value. One can only await the continuity of the growth of illegal businesses and the social ills associated to them.

In spite of the public, judicial and historical knowledge that clandestine drug commerce favours important and disruptive channels of corruption, mobilised through the necessity to wash enormous quantities of money and also operations of profit distribution, including scandalous politicians of parallel diplomacies and sales of arms to the outside world, addressed somewhat in numerous documentaries and films (Woodiwiss, 1988), there persists the political success of the moralist and irrational appeals to the stigmatisation and criminal penalisation of illegal drugs and of their consumers. The practical effects of this approach are the turning of this sector of activity into one of the most voluminous and lucrative in the world. The law enforcement and penal institutions and forces are confronted, thus, with an extraordinary mobilisation to give form to such a tactic that, defeat after defeat, hopes to feed a Pyrrhic moral victory. ${ }^{29}$

The political and moral indifference regarding the daily loss of authority on behalf of the State security leaders, evidently and structurally powerless to deal with the "competition" of the enormous amount of drug traffickers and consumers, characterises a social configuration by which the hiding of corrupt practices can easily be confused with practices of infiltration or criminal investigation, under organisationally deficient

Sobre as Políticas Europeias Contra a Droga" in Boletim da Abraço no. 4,2005.

We refer here to the culture of benevolence in view of the procedural ease capable of providing the level of decisive arbitration sufficient to fulfill the political designs of prohibition, in particular through the systematic absence of references to the defense of the constitutional rights of the accused and to uncontrolled means of acceptance of proof in court (together with the weakness of the scientific police) that characterise the Portuguese judicial system, beginning with the universities.

29 In Portugal, the theme of sharing needles in the jails has occupied the polemic space: how to protect the health of the detained intravenous drug users, without recognising the existence of trafficking inside the State security institutions? The answer has been the impasse, which has not been neutral. 
conditions..$^{30}$ It is not possible to put more addicts into overcrowded and infiltrated prisons. It is not possible to persecute all of the traffickers, it being easier to capture those at the end of the line-a practice which has caused the number of female prisoners in Portugal to grow significantly. However, severity and devotion are needed in the "war on drugs", a conflict abandoned to the solders armed with little more than the "authority" delegated by the state! ${ }^{31}$

The selection of the defendants who are sent to stand before the judges is, therefore, necessarily discretionary, and based upon a particular social profile. The final results can be observed in the prison populations, constituted, in the rest of the world as well as in Portugal, by the more socially isolated and dispossessed of the consumers/traffickers-to-feed-the vice.

The intermediary results are not as visible to the naked eye. Frequently in law enforcement cases, where "forces of order" and "alleged bandits" are confronted, the versions of the occurrences not only don't coincide with, but are contradictory to, those aspects which could have juridical and penal relevance, for obvious reasons. In this juridically protected debate, in principle, the first have an advantage over the second before the judge, especially when ex-convicts are concerned..$^{32}$ This does not always happen, however, such as when influential lawyers enter in dispute and when tactics of investigation are discussed in detail in the court. Another exception is when, in the heat of the fight (to use a sporting expression), the agents of the authorities involve themselves in condemnable practices, whose sanctioning is extremely susceptible to political conditions, namely those stemming from the accompaniment - or lack thereof - of the cases by the media and by the non-governmental organisations. ${ }^{33}$

Recently, in the police and prison guard union environments, allegations have appeared of disciplinary and criminal processes being excessively established against elements of these organisations. It can be deduced, therefore, that the public denunciations of the abuse of power on the part of the agents of the State are having an effect on the political and judicial levels. This is not happening so much in the form of a questioning of the prohibitionist policies, as much as a testing of the political will of the State in the persecution of corruption and of

30 Regarding the socio-political context of this type of contradiction, see Soares (2000).

31 Regarding this theme, see Morgado (2003).

32 In the portuguese judicial hearings theres is the practice of the defendants, of the judge asking for the respective criminal antecedents as a complement to the identification of the accused.

33 Complaints of neglect, maltreatment and even homicide have in recent years been directed against Portuguese prison guards, whose criminal processes have been delayed, as is the case with all judicial processes in Portugal. International organisations, such as Amnesty International, have come to be involved in some of these cases with a growing emphasis on more recent reports. 


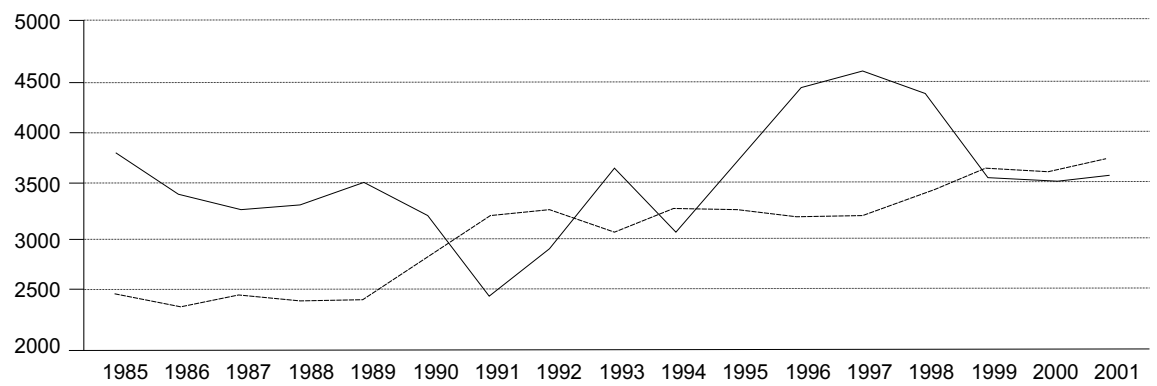

risk of incarceration _-_----. crime por 100 million inhabitants (admitting 10 million inhabitants)

Figure 9.1 Risk of incarceration and crime rate in Portugal

Source: data from DGSP (General Direction of Prison Services) website, http://dgsp.mj.pt/.

the torturers, measured by number of complaints entered, the number of processes established, and the respective condemnatory results. ${ }^{34}$

The complaints against the arbitrariness in the "hunt" for drug users are reflected in the hunt, allegedly also arbitrary, for "bad" authority agents. The prohibitionist policies now correspond to the anti-torture policies, which seek to prevent the uncontrolled expansion of the practical results of amoral institutional behaviour which has developed along the course of the past decades.

It can be concluded that the prohibitionist spirit directed against the consumption of drugs, and which has as a practical result the development of more social problems than the prohibitionists want to fight morally, is expanding its punitive influence in the direction of the policing agencies, as a reflection of the social reaction to the induced arbitrariness of criteria at the service of the security forces. ${ }^{35}$

34 There has been a growing concern over these themes, as can be observed, for example, in sociology through the reemergence of interest in penitential themes, inexistent in the last decades of the past century. The General-Assembly of the U N has also approved the Additional Protocol to the Convention against Torture and Other Cruel, Inhuman or Degrading Treatment or Punishment (of 1987), adopted on 18 December 2002. This attempts to internalise and intensify the internationally consecrated practices of torture prevention, an action which is causing the review of some policies of some human rights associations which have previously only been concerned with occurrences in Third World countries. These associations understand today that there is a battlefront to be addressed in the very heart of western civilisation.

35 Woodwiss (1988) registers the way in which the diverse prohibitionist waves of the past ended with a scandal of corruption that produced a political point-of-no-return, after a series of scandals at the same time but without apparent practical effects. 
Young (1999) recognises that, scientifically, the data of crime and of incarceration are not mutually related. The respective series is developed, in each country, according to unique and unexpected manners. ${ }^{36}$ However, he defends that the registered criminality and the risk of incarceration are distinctive features of the social identity of each society, depending upon the situation and in comparison with other States.

In the case of Portugal, we can observe four situations: a) the tendency to maintain the registry of crime and of growth weighed by the risk of incarceration, until 1990; b) the pinball reaction of the risk of incarceration, resulting from the policy of recourse to the regular amnesties to contain the aggressive punitive penal impetus, resulting from apparently uncoordinated reactions of the punitive judicial system and of the administrating political power, to the growth of crime, until 1995; c) the penitentiary bubble, which resulted from the auto-inhibition on the part of the politicians regarding the use of amnesties, until 1999; d) a rebalancing of the risk of incarceration, obtained with the help of the partial pardon which was commemorative of the 25 year anniversary of the Portuguese Revolution ("The Revolution of the Carnations"), a rebalancing which has been maintained until today without further pardons. This last period is also characterised by the public self-recognition, through a presidential initiative, of the Portuguese judicial crisis. ${ }^{37}$

In the prohibitionist perspective, which develops the belief of there being a dissuasive relationship between the quantity and quality of punishments applied and the propensity for crime, the interpretation in otherwise. The hesitation of the Portuguese authorities in combating the consumption of drugs, spread throughout the second period, lessened the dissuasive effect (by way of the rational calculation of the criminogeneous agents) and augmented the opportunities for crime. In this sense, only the penitentiary bubble will have stopped the increase in criminality, from which we benefit.

Perhaps the only flaw in this imaginative and functionalist interpretation is the fact that it is not the only one possible. In fact, what impedes us, using the same carefree methods, from thinking that, once we observe the partial removal of the drug market and of the neighbours who turn to these

36 One must resist the interpretation of the proximity of the lines in figure 9.1 as some type of correlation (which in fact does not exist), or of any type of rational proportion, which is negated by many indicators. One should furthermore keep in mind the precariousness of extremely politicised statistics, as these are, the criticism of which could profoundly alter the data. For example, different authors could produce different series of numbers of prisoners in Portugal, whereby the increase could be calculated, from 1974 to 2000, as either 5 or 6 times (that is, with an error of $20 \%$ ), depending on whether or not military prisoners and the various situations of those protected from accusation were to be considered. See a short, informative and penetrating diagnosis of this crisis in Vasconcelos (1998). 
Table 9.1 Evolution of the number of prison guards in Portugal, 1994 to 2003

\begin{tabular}{lrrr}
\hline Year & 1994 & 1999 & 2003 \\
\hline Prisoners & 10.360 & 13.138 & 13.835 \\
Guards & 2.851 & 3.864 & 4.735 \\
Guards per 100 prisoners & 28 & 30 & 34 \\
\hline
\end{tabular}

Source: data from DGSP (General Direction of Prison Services) website, http://dgsp.mj.pt/.

forms of commerce within the prisons, the operation of institutionalisation of the illegal practices will have been the main cause of the lesser criminal evolution, given its informal "nationalisation"? In other words, why should there not be resources inside the prisons to fight the combat which, outside, fills the prisons?

In Portugal, there allegedly exists a tradition of a tremendous social proximity and interaction between the prison guards and the prisoners, to the point that, in the prison environment, there is praise - as opposed to the doctrine related tendencies in the other European prison systems, which are more techno-bureaucratic, shall we say-for the specificity of the inter-relational ability and humanity of the prison guards, who will have to serve the prisoners' needs for psychological, social and therapeutic support, given the overpopulation and the scarceness of resources of duly qualified technicians..$^{38}$ In light of the public declaration of the crisis of the Portuguese prison system, with high points in 1996, with the release of the first report of the Portuguese Ombudsman's office in 2001, with a preventative dispute of the prisoners against the injustice of which they felt themselves to be targets, and in 2004, with the presentation of the Freitas do Amaral report on the perspective of the next 12 years, the Union of the Prison Guard Corps was noticed for its special ability to place demands relative to the unions of other prison workers..$^{39}$ It benefited from the political emphasis upon security aspects, as pragmatic solutions for emerging

38 This specificity of the Portuguese case is accompanied on one hand by the recognised (dis)organising Portuguese specificities and, on the other hand, by the fact of the prison sector not having mobilised, until very recently, any intellectual or academic curiosity, to the point that General Director João Figueiredo, confronted with the plan from the guardianship proposing prison reform, publicly manifested the lack of information and reflection about the subject, in the case of Portugal.

39 While the Portuguese law determines social reintegration to be the main end of its punishment, such determination has not been considered in practice, as can be proven by the absence of statistics regarding the service of specialists, before 2003, as opposed to that which happens with the guards, by the inexistence of social services for accompanying conditional liberties, or even by the inexistence of individual processes foreseen in the law and of procedures of social reintegration of the ex-prisoners. There is an anecdote, supposedly true, of a prisoner with one leg who went out into liberty hobbling on his one foot, because the crutch that he used for walking was the property of the prison services. 


\begin{tabular}{lccc}
\hline Higher specialists & Administrative specialists & Workers & Guards \\
\hline 552 & 737 & 375 & 4735 \\
\hline
\end{tabular}

Source: data from DGSP (General Direction of Prison Services) website, http://dgsp.mj.pt/.

problems, in particular for the contention of the eventual public alarm regarding the news of the prisoners' arrival. ${ }^{40}$

The prohibitionist spirit concentrates on the security values of investments. It also is evident, however, in other forms, particularly in a culture of secrecy and manipulation, capable of protecting its own image of the practical consequences of the reigning irrationality. It has really not been possible in Portugal to conduct studies about prison guards, since these individuals have been indoctrinated and thereby willingly refuse to collaborate with projects of rational investigation, even with scholastic works, and even anonymously. ${ }^{41}$

This situation increases the tendency to make scapegoats out of the prison guards regarding the occurrences, more or less scandalous, that are regularly made public, exonerating the general policy. In practice, the Portuguese have been able to reduce the penitentiary problems to cases between "police" and "thieves". They are presented in this way, whether in specialised or more popular channels of media.

Being practically the only professionals with direct contact to the prisoners, it falls upon the guards to explain everything that happens, whether that be suicide, escape, torture, mistreatment or negligence in health attendance, without revealing the daily irrationality to which they are perpetually subjected. ${ }^{42}$ Due to professional obligation, they have to keep quiet about and subjected to the official truths, sometimes opposed to the counter-truths divulged as denunciations. The guards remain among the principal suspects of public opinion who benefit from the profit of illegal trafficking in prisons, suspects systematically dispatched again and again to the relatives who visit the detainees.

$40 \quad$ For an elaboration of this theme, see Dores, 2004.

41 The spirit of the siege and the feeling of being hostile towards the exterior are evident and reach all the Professional groups of the prison services. However, the extremely rigid respect for the law of the secret professional must be explained by the inferiority complex and guilt in the face of rational elaboration, which is allegedly not applicable in prisons. As we have explained above, the guards are publicly decorated for the availability which characterises them for dealing with the organizational confusion and the lack of defined responsibilities. They remain loyal to this promise by the radical respect for the secret professional. 


\begin{tabular}{lccc}
\hline & National & EP Central and Specials & EP Regional \\
\hline Total & 42 & 30 & 12 \\
Suicides & 12 & 11 & 2 \\
By illness & 29 & 19 & 10 \\
In Caxias Prison Hospital & 4 & 3 & 1 \\
In Town Hospital & 2 & 1 & 1 \\
Preventives & 28 & 17 & 11 \\
Primaries & 12 & 6 & 6 \\
\hline
\end{tabular}

Source: DGSP (General Direction of Prison Services), answer from 2 Dec. 2004 from the Secretary of Justice to the 3 requests of Deputy Isabel Castro of the PEV (the Green Party), from 12/3, 15/4 and 6/5 of 2004./

Theoretically, one can hypothesise the existence of a cause-effect relationship between the typical organisational method of Portuguese society (that is, the ambiguous bureaucracy with a nearly dominant informal sector), and the difficulties in the attribution of political, administrative or even criminal responsibilities ${ }^{43}$ Be that as it may, the Portuguese prison obituary it persistently among those of the highest levels (in 1997, it stood out for holding the European record). ${ }^{44}$

The rate of hospital support, in this scheme, is $14 \%$, for a young population, with high percentages of narcotics usage, to which is added the massive consumption of psychotropics provided by the prisons, rates of uncontrolled infectious-contagious diseases, ${ }^{45}$ and mental health care provided as a support to the security crises in the establishments, but which is insufficient, according to the declarations of doctors who are responsible for the mental

43 The Judicial Police has publicly confessed to facing particularly difficult obstacles when investigating prison environments. One of the most serious problems in Portuguese prisons is their organisational "backwardness": "(...) management tools do not exist; there is no communication among the services; vagueness or confusion regarding responsibilities is evident among the services; the same tasks are repeated countless times or by different services, with the implementation of multiple procedures; irresponsibility and lack of solidarity are evident in the discomfort felt by the workers and directors, regarding the making of decisions; salary discrepancies among workers of the same category or who perform the same type of tasks are evident and disturbing; the establishments that have administrative autonomy behave as if they were independent from the general-direction, but without having the human, technological, financial or structural means corresponding to that performance (...)" in Brito (2004).

44 In this year, the number of deaths in Portugal put this country in first place in the context of the European Council, with the extraordinary rate of 106 deaths per 10,000 detainees. Russia was in second place with 78. 
Table 9.4 Deaths in Portuguese prison establishments

\begin{tabular}{lccc}
\hline Deaths per & 2004 & From 1997 to 2004 & Averages between 97/04 \\
\hline Total & 75 & 687 & 86.0 \\
Suicide & 22 & 123 & 15.0 \\
Natural causes & 53 & 559 & 70.0 \\
Homicide & 0 & 5 & 0.6 \\
\hline
\end{tabular}

Source: data from DGSP (General Direction of Prison Services) website, http://dgsp.mj.pt/

Table 9.5 Non-nationals in Portuguese prisons 2003

\begin{tabular}{lrc}
\hline & Men & Women \\
\hline Africa & 1.202 & 70 \\
Europe & 613 & 63 \\
Latin America & 278 & 74 \\
\hline
\end{tabular}

Source: data from DGSP (General Direction of Prison Services) website, http://dgsp.mj.pt/

health services of the Prison Hospital, to allow the continuity of efficient treatments by their being prolonged. People imprisoned with curable mental illnesses go without treatment.

Portugal is confronted with a growing presence of non-nationals, who are judicially discriminated (cf. Seabra and Santos, 2005), as happens in other systems of the world. Their presence in Portuguese prisons are as follows: of the 13,635 prisoners at the end of 2003, there were 2,145 non-nationals, of which group $10 \%$ were women (versus $8 \%$ of the total of prisoners in Portugal at the same time). Five per cent of the Portuguese population was then foreign, which accounts for $10 \%$ of the active population and $15 \%$ of the prison population, in the same year. Currently, unemployment has been strongly affecting the immigrants, and the rate of non-nationals in the prison population will have grown to $17.5 \%$.

These numbers do not reveal that the ethnic disproportions of incarceration are greater, being that African immigrants have Portuguese children and, therefore, they are not counted in these numbers, although they are present in the prisons in significant quantities. Furthermore, nomads (usually of Gypsy ethnicity) are not registered for statistical reasons, but they constitute a recognisable presence in the prisons.

45 In 2004 in Portugal, 23300/0. 2\% cases of HIV/AIDS infection were detected, with $15 \%$ in the prisons. The numbers known carriers of Hepatitis C increases by $30 \%$ in 2001 , according to the Portuguese Ombudsman. Tuberculosis also has a high rate of occurrence in the prisons. 


\section{Preventive Sociology}

Portuguese modernisation, centred upon the European integration which began in 1986, was a national decision. It grew out of the revolution which put an end to the colonial empire and the anti-democratic practices that prevailed before 1974. Contrary to that which occurred with the Spanish entry, the then European Economic Community did not demand of Portugal any reform of its Judicial-Penal system. Perhaps this approach resulted from the preconception that the revolution would not leave one stone on top of another, or that this particular change would be a sufficient guarantee of integrity. If this was the case, it was wrong. In 1996, the government at the time was attacked politically by the denunciation of the Portuguese Ombudsman and decided to "throw money at the problem" (according to the Tribunal de Contas - that supervise the Portuguese State budgetary processing - interpretation stated in the report no. 6/2000). This was the first time that a government made a investment decision regarding the penitentiary institution, since before the $25^{\text {th }}$ of April - a time in which the recourse to prison penalties was lower than at present, in a proportion similar to that which separates Portugal from the USA today. Sanitary bucket practices remain today, taking the place of absent lavatories. Furthermore, even today, the State's and/or government's lines of action regarding penitentiary policy are not publicly known. How can one decide between a) the legalist declarations that place a priority upon the social reinsertion of delinquents and $b$ ) the security practices connected to the practical consequences of the prohibitionist practices?

We use the formulation controversy model of the current secretary of Foreign Business - who previously has been the president of the Commission for Prison Reform during the rule of the previous government-when he declared his personal opinion to be that the European constitutional treaty would be dead, after the contrary votes of France and The Netherlands, even though the official position of his government was that of maintaining the belief in the possibility of the affirmation of that treaty. In the same manner, facing momentous penitentiary questions, the objective of the national political declarations seems to be less the clarification of a course of action as much as a way to gain some time; it seems to be less the exercise of rational evaluations of the situation as much as a worry over maintaining stable emotional balances ("feelings of security") and the enlarging of the limits of manoeuvring in any direction that might become necessary to pursue, the hitching of external interests to the moral and political determination of the state authorities.

Along with having an open economy, Portugal is also a country open to foreign political trends (for historic and structural reasons) which, however, are incorporated into the national sentiment. In general, foreign nations are 
objects of special reverence in our country. ${ }^{46}$ For five centuries, they have been our potential clients. As Agostinho da Silva would say, we have become the foremen of the world, the intermediaries in loco of North-South relations. As for any small citizenry in this condition, it is necessary to develop special mediation skills, such as politics for show in the exterior. This technique was exploited, for example, by the Salazar regime following the defeat of the Axis powers, of whom Portugal remained a neutral ally during the Second World War. The Portuguese State staged a democracy, which some of the founders of the democratic state came to denounce as a farce. There are those who suggest that the Portuguese judicial and penal system has passed safe and sound through the revolutionary times of the mid 1970s, having permitted, in the core of the institutions, the survival of irrational strategies, more appropriate to less modern regimes. ${ }^{47}$

The social configuration, of which we herein show a few identifying traces, is structurally reinforced by the fact that there are few established resources of political and institutional reflection and criticism, in spite of there being a significant unemployment of university graduates, in particular in the area of Law..$^{48}$ There is a plagiaristic practice regarding theoretical formulations and doctrines, often in their purer forms. It's not uncommon for Portugal to see itself to be served by the best laws on the planet. As is well known, the political struggle that counts in practice is developed behind the scenes, where it is possible to indefinitely suspend the regulatory process of politically approved laws, making them valueless. This is also where it's possible to definitively adopt provisional dispositions, ones that are even eventually illegal, regarding which demands of acquired rights can later be made. In this state of things, the importation of technology of power, such as, for example, the security strategy known as "zero tolerance", would be confronted with a disorganisation of the administrative and informational services, whose informality prevails and whose computerisation would be prolonged for many years, eventually shaping the imported strategy to the indigenous characteristics rather than vice-versa. Here lies an obstacle to

46 Previously colonised peoples can not benefit from this affable relationship.

47 This very idea was expressed in a parliamentary audience by António Marinho e Pinto as President of the Commission on Human Rights of the Order of Lawyers. For having expressed himself against the "inquisitorial practices" in force, he was dismissed from his post. In the following elections, as a candidate for the "Bastonário da Ordem" (the Order's Sergeant at Arms), he obtained a significant percentage of the vote, in spite of the traditional conservatism of the Portuguese lawyers' vote.

One of the most current and controversial questions in the debate over the crisis of Justice in Portugal has been that of the initial and continual education of lawyers and, in particular, judges, whose school, the Centre for Judicial Studies (Centro de Estudos Judiciários), has come to be accused of corporate and ceremonious bookishness, as well as of the lack of life-long learning opportunities. 
the realisation, in Portugal, of the penitentiary risk, even if it's not done for the best reasons.

So-called alternative penalties in the USA correspond to $21 / 2$ times the number of imprisoned people, while they account for practically zero of the cases in Portugal. Without practice nor experience, without structures or specialised personnel, there is also, here, a difficulty in following the penitentiary danger, again not for the best reasons.

Portugal has been in a position of formally maintaining an administration capable of corresponding to the demands of international participation in the diverse agencies that collect information, seeking to give an image of a developing country, independently of that which might happen inside the country, as is the case of the indexes of poverty, scholar qualifications or literacy. Proof of this can be found in the form of the "Instituto de Reinserção Social" (Institute of Social Reinsertion), created in 1982, and whose prestige of strictly formal treatment of legal proceedings is unquestioned. Further proof can be found in the chronic budgetary crisis, on two levels. One involves the discussion between assuming the real deficit in light of the European Union, or touching up the budget to avoid sanctions - yet another emergence of the "for show in the exterior" policy; the other is the unanimously recognized disparity between the volume of investments in public services and their practical performance.

This schizophrenia is a source of complaint by the professional educators in prisons and the social reinsertion professionals of the Instituto de Reinserção Social. This has made it difficult for a long time to believe that all the responsibilities which are professionally and legally addressed by them will be taken seriously.

The risk that the influence of the North-American experience might aggravate the security tendencies on Europe is undeniable. The exportation of the Penal State as an alternative to the Social State is not out of the question. However, this will not only basically involve a process of technological transference of strategies of power or of penitentiary models. The European and North American social structures are rooted in histories, institutions and people who have inherited them, lived with them, and who live for and from them. That which the security tendencies on both sides of the Atlantic-and probably in other parts of the world - have in common is the prohibitionist spirit. The innate tendency to make shocking violence echo over the explicit symptom of violence, with the expectation that this will be effective in the eradication of the equivalent symptoms and of the arising problems, without it being necessary to pay attention to the subject.

This tendency, which is probably genetically programmed in all animals, once realised, offers a sentiment of security, of forgetting, and of helping to conduct the fight, if it is such a case. It is, as such, a gift to satisfy the electorate and, moreover, to help them forget the problematic topics... 


\section{References}

Boltansky, Luc, and Ève Chiapello (1999), Le Nouvel Esprit du Capitalisme, Paris, Gallimard.

Bourdieu, Pierre (2001), As Estruturas Sociais da Economia, Lisbon, Piaget.

Brito, Miguel Villa de (2004), Trabalhos Preparatórios da Revisão Orgânica da Direcção-Geral dos Serviços Prisionais. Análise e Fundamentação das Necessidades de Reestruturação Orgânica da Direç̧ão Geral dos Serviços Prisionais (manuscript).

Cardoso, Gustavo et al. (2005), A Sociedade em Rede em Portugal, Lisbon, Campo das Letras.

Castels, Manuel (2004), A Galáxia Internet. Reflexões sobre a Internet, Negócios e Sociedade, Lisbon, Fundação Calouste Gulbenkian.

Chaves, Miguel (1999), Casal Ventoso. Da Gandaia ao Narcotráfico, Lisbon, ICS-UL.

Costa, António Firmino da, et al. (2000), "Classes Sociais na Europa”, Sociologia, Problemas e Práticas, 34, Celta Editora, pp. 9-46.

Costa, Eduardo Maia e (2003), "Prisões: a lei escrita e a lei na prática em Portugal" in António Pedro Dores (org.), Prisões na Europa. Um Debate Que Apenas Começa (European Prisons. Starting a Debate), Oeiras, Portugal, Celta Editora.

Cunha, Manuela Ivone (2002), Entre o Bairro e a Prisão. Tráficos e Trajectos, Lisbon, Fim de Século.

Dores, António Pedro (2004), “Anomia em Durkheim: entre a Sociologia e a Psicologia Prisionais", Direito e Justiça, special number, Lisbon, Faculdade de Direito da Universidade Católica Portuguesa, pp. 95-118.

Dores, António Pedro (2005), Espírito Proibicionista, Oeiras, Portugal, Celta Editora.

Gonçalves, Eduarda (ed.) (2000), Cultura Científica e Participação Pública, Oeiras, Portugal, Celta Editora.

Lyon, David (2001), Surveillance Society, Buckingham, Open University Press.

Morgado, Maria José, and José Vegar (2003), O Inimigo Sem Rosto. Fraude e Corrupção em Portugal, Lisbon, Publicações Dom Quixote.

Provedor de Justiça (Portuguese Ombudsman) (1996), Relatório sobre o Sistema Prisional, Lisbon, Provedoria de Justiça.

Provedor de Justiça (Portuguese Ombudsman) (1998), As Nossas Prisões - Relatório sobre o Sistema Prisional, Lisbon, Provedoria de Justiça.

Provedor de Justiça (Portuguese Ombudsman) (2003), As Nossas Prisões - Relatório sobre o Sistema Prisional, Lisbon, Provedoria de Justiça.

Reich, Robert B. (1991), O Trabalho das Nações, Lisbon, Quetzal.

Tribunal de Contas (Court of Audit) (2000), Relatório de Auditoria, 6, Lisbon, Tribunal de Contas.

Roberts, Julian V., and Mike Hough (ed.) (2002), Changing Attitudes to Punishment. Public Opinion, Crime and Justice, Devon, Willan Publishing.

Santos, Boaventura Sousa, Conceição Gomes, et al. (2002), As Tendências da Criminalidade e das Sanções Penais na Década de 90. Problemas e Bloqueios na Aplicação da Pena de Prisão e da Prestação de Trabalho a Favor da Comunidade, Coimbra, 
Portugal, Observatório Permanente da Justiça Portuguesa e Centro de Estudos Sociais.

Santos, Boaventura Sousa, et al. (1996), Os Tribunais nas Sociedades Contemporâneas. O Caso Português, Oporto, Afrontamento/Centro de Estudos Sociais/Centro de Estudos Judiciários.

Seabra, Hugo Martinez de, and Tiago Santos (2005), A Criminalidade de Estrangeiros em Portugal. Um Inquérito Científico, Lisboa, observatório, ACIME:

Soares, Luiz Eduardo (2000), Meu Casaco de General. Quinhentos Dias no Front de Segurança Pública do Rio de Janeiro, S. Paulo, Companhia das Letras.

Toffler, Alvin (1980), A Terceira Vaga, Lisbon, Livros do Brasil.

Young, Jock (1999), The Exclusive Society, London, Sage.

Vasconcelos, Pedro Bacelar de (1998), A Crise da Justiça em Portugal, Lisbon, Gradiva /Fundação Mário Soares.

Vaz, Maria João (2000), "Ideais Penais e Prisões no Portugal Oitocentista" in Actas do IV Congresso Português de Sociologia, Sociedade Portuguesa: Passados Recentes, Futuros Próximos (http://www. aps. pt/cms/docs_prv/docs/DPR462dbba49c41b_1.PDF).

Vaz, Maria João (2004), “Crime and political opposition? Lisbon 1885-1910” paper to V European Social Science History Conference (not published), Humbold University, Berlin, 24-27 March.

Wacquant, Loïc (2000), As Prisões da Miséria, Oeiras, Portugal, Celta Editora.

Woodiwiss, Michael (1988), Crime, Crusades and Corruption. Prohibitions in the United States, 1900-1987, London, Piter Publisher. 


\title{
Company-level labour relations and the industrial relations system in Portugal
}

\author{
Alan Stoleroff
}

The most well-known and influential statement of the concept of an industrial relations system is taken from John Dunlop (1958: 7): "An industrial-relations system at any one time in its development is regarded as comprised of certain actors, certain contexts, an ideology which binds the industrial-relations system together, and a body of rules created to govern the actors at the work place and work community." 1 The "web of rules" that produces the government referred to by Dunlop ${ }^{2}$ can emerge at various levels of interest aggregation where there exist relations amongst the actors, namely the employers and their representative associations, workers-employees and their unions: a national macro-level above the companies and branches consisting of the peak associations of employers, labour unions and the State, an intermediate meso-level above the company and made up of employers' associations and branch (or "industry"), level unions or federations, and a micro-level

1 As opposed to the definition of industrial relations systems as such, the definition of industrial relations as an object and field of study has suffered a significant evolution since Dunlop published his seminal work (Kaufman, 2004). Dunlop defined industrial relations succinctly as "the complex of interrelations among managers, workers, and agencies of government. " Four decades later Visser defined industrial relations comprehensively as "the study of strategic choice and collective action of labour, business and governments, their mutual relationships of conflict, cooperation and power, affecting the content and regulation of employment relations and the use and distribution of physical and human resources. " (Visser, 1996: 2)

2 The establishment of rules for the "procedures for establishing rules, the substantive rules, and the procedures for deciding their application to particular situations" are "the centre of attention in an industrial-relations system. " (Dunlop, 1958: 13) Nowadays we might use the term "governance" to refer to the "web of rules" if we wanted to make a point of using such "post-modernist" jargon. Where Dunlop states that the industrial relations system interacts with the economic system but is not coterminous with it, nowadays we might say that industrial relations systems - if there are any forms of joint regulation present at a given level of employment relations - interact with but are not coterminous with corporate governance. 
made up by representative actors within company and workplace (Dunlop, 1958: 23-28). Governance and regulation also involve the forms of articulation between these levels and, therefore, the diverse national industrial relations systems are differentiated by the degrees of centralisation of this articulation, that is, systems are differentiated by which of these levels predominates as a locus in determining the dynamics of regulation (Traxler, Blaschke and Kittel, 2001). ${ }^{3}$

Nevertheless, the core of any industrial relations system, regardless of its degree of decentralisation of employment regulation, consists necessarily of labour relations at the company level. This is because workplace relations are the very object of regulation efforts. ${ }^{4}$ Even when taking into consideration the fundamental function that collective bargaining at the meso level plays as the regulatory mechanism of inter-company wage competition in relatively coordinated systems, the level of workplace labour relations is the point at which the effectiveness of the employment system is tested.

Raising the problem of the articulation between micro and meso levels of regulation involves, in the first place, the question of the emergence (or disintegration) of a system, seen as systematised employment relations or "joint regulation". The use here of the term "system" is neither fortuitous nor idiomatic. It refers to a set of actors, institutions and regulatory mechanisms of interaction and negotiation. In contrast with the term "system", the term "pattern" would refer to a mere set of actors and institutions (Stoleroff, 1990, 1995). At a certain point there is a distinction even between a very highly decentralised system of industrial relations and a fragmented or segmented pattern of industrial relations in which employer unilateralism is prevalent.

3 It is the problem of this articulation of levels of regulation that makes industrial relations a core focus of literature on corporatism. The democratic transition initiated in 1974-76 makes this literature particularly relevant to the study of the emergence of industrial relations systems in Portugal. A good example is found in Schmitter's discussion of democratic consolidation (1995: 284-287) where he refers to the emergence of a "second generic channel of access to political authority in modern democracies, that of the direct representation of class, sectoral, and professional interests through specialized, permanently administered associations. " He further points out the importance of the potential continuity of "functional channels" for interest representation as a factor in legitimation processes. Industrial relations systems in this sense can be seen as one of the "bundles of diverse institutions or 'partial regimes' that link citizens to public authorities".

4 Considering the importance of labour costs and issues for organisational strategy, and considering how unions can potentially emerge as counter-powers in organisations, industrial relations concerns are conspicuously absent from the sociological study of organisations. Writers such as Guest (1995) have raised industrial relations issues within the human resource management literature but they seem to be relatively rare creatures. Stoleroff (1996) addresses some of the industrial relations issues in HRM in Portuguese. Guest has recently introduced the question of "partnership", which dovetails with industrial relations concerns, into the important organisational debate on "trust" (Guest et al., 2008). 
Although the construction of a system may be initiated through protagonism of the State or peak associations and induced by agreements and measures taken at the macro level (for example, following functionally virtuous legislative reforms or a social pact between employer and trade union peak associations), the emergence of systemic properties depends upon both the degree of acceptance and conformity of the actors to the rules at the micro level as well as the effectivity of the rules. ${ }^{5}$ (The disintegration of a system similarly but inversely refers to the breakup of a system through the rejection of relationships based upon recognition and joint regulation.)

Thus, a subsequent question becomes that of legitimation. In principle, and presuming there is no higher-level compulsion or recourse to force in conjunction with the application of the rules established at the macro level, in order to obtain effective conformity the rules must be accepted as legitimate by the actors subject to them. Legitimation may derive from various logics of incentives but without legitimation, there is neither cohesion nor adherence, and therefore the capacity of the system to maintain itself intact and to achieve an effective regulatory capacity would always be limited. The source of such legitimation lays precisely in the labour relations at the ground level, that is, the individual company level labour relations. ${ }^{6}$

Along these lines, beyond the assumptions derived from the general theory of systems, the paradigm of industrial relations systems is based upon two empirical preconditions: the presence of actors, that is employer and

5 In this regard, Santos (1985) referred to the "internal disarticulation between capitalist production and social reproduction" as a theoretical context for analysing observations with regard to significant non-conformity of the social actors at the micro level to the rules established through constitutional, governmental and legislative regulation. In other words, the economic mechanisms at micro level and the behaviour of the actors involved in collective bargaining and labour relations in general do not assure obedience to the established normative framework. On the other hand, and in contrast with the Spanish case, it can be claimed that the effectiveness of the constructed "web of rules" is undermined in Portugal by deficiencies in the normative framework itself. This problem especially concerns the issue of the representativity of the actors (Martins, et al., 2004).

6 The conflicting interests involved in recent Portuguese history made it - and continue to make it - difficult to construct consensus, that which Dunlop understood as the necessary ideology for the cohesion of a system of industrial relations: the revolutionary transition from the corporatist dictatorship to democracy and the sequels it inspired in the content of the normative framework of labour relations and the protracted process of the reconstitution of the private market economy that took place in opposition to the very norms established in the aftermath of the transition. The weakness of the legitimation derived from this situation makes it difficult to obtain mutual recognition amongst the actors and indeed even to constitute autonomous actors, especially the trade unions, as actors of the system. Relating these issues once again to the literature on democratisation, there is a parallel here with the proble of democratic consolidation which Gunther, Diamandouros and Puhle (1995: 7) define as being achieved only "when all politically significant groups regard its key political institutions as the only legitimate framework for political contestation, and adhere to democratic rules of the game." 
management bodies and representatives of the employees (generally unions), and mutual recognition and relevant interaction between them (Dunlop, 1958; Clegg, 1976). The institutionalisation of joint regulation may develop from such recognition. ${ }^{7}$

To a certain extent Dunlop and his companions within the systems current assumed the emergence of a pluralism of functioning representatives, that is, the presence of actors, as a natural consequence of industrialisation (Kerr, et al., 1964). However at the company or organization level, while the presence of a managerial actor may be taken for granted, the existence of organisational forms of representation of labour, namely the unions, is always problematic. Trade unionism rests fundamentally upon its capacity to organise workers as the employees of given companies and upon the institutionalised intermediation between the employer and workers resulting from the recognition of its representative functions. It is necessary to collectivise, associate and unionise waged employees in order to produce a union actor; it is necessary to impose recognition and maintain the organisation. The difficulty in assuring and giving continuity to the presence of a union actor is reproduced in each organisation and is reproduced periodically, if not constantly.

The existence of an external trade union organisation, whose role and presence in the institutions of bargaining at the higher levels of aggregation are protected by the law, is not a sufficient condition for establishing the relevance of a union organisation within the companies. At the company level or within an individual organisation, a representative union organization means the construction and maintenance of a "domestic organisation". ${ }^{8}$ The "domestic organisation" depends upon the capacity of a union organization to recruit and maintain members, thereby endowing it with a representative function, and in the capacity to make itself recognised by the employer. To conclude, the presence of a "domestic organisation" is a condition for the establishment of joint regulation at the company or organisational level. Nevertheless, in the absence of a recognised union interlocutor, the management actor does not give up its management function; to the contrary, in accordance with its "strategy" the managerial actor may engage in efforts to avoid union recognition and promote unilateral regulation.

On the basis of these premises over the last decade we have conducted research on company based labour relations in order to ascertain to what

7 See Hyman (1972: 74-105) for a detailed review of the question of the institutionalisation of industrial conflict. See Stoleroff (1990) for a discussion of this theme applied to the Portuguese context.

Concept developed by Batstone, Boraston and Frenkel (1977) to refer not only to workplace union organisation but to the relationship between workplace union and the workers. 
extent the preconditions for the development of an articulated system of industrial relation have emerged in Portugal. ${ }^{9}$ In this chapter we deal with the problematic discussed above with reference to some of the results of two national surveys of micro-level labour relations in Portuguese companies. We seek to verify the presence of actors within the firms, the effectiveness of the forms of regulation established at levels above the companies (the articulation between the meso and micro levels) and the degree of mutual recognition among the actors at company level.

To this effect we develop an opposition between bilateral and unilateral forms of regulation of labour relations at company and organisational level. Practices of bilateral or joint regulation consist of collective bargaining or other forms of negotiation between company management and employee representatives. Unilateralism is understood evidently as the opposite of practices of joint regulation, referring to the imposition of employment conditions by one or other of the actors. As it is exceedingly rare for conditions to exist where unions impose their definition of the employment relation upon employers, unilateralism will be understood as unilateral acts on the part of management. Thus, one of the goals of this chapter is to explore the relation between unilateralism and joint regulation in the management of labour in Portuguese companies through the presentation of data obtained from the two surveys and to confront the systems paradigm of industrial relations with these results.

Therefore we will be portraying some of the elemental characteristics of company-level labour relations in Portugal, taking stock of this component of the "pattern", and drawing out the consequences that the empirical analysis might have for the conception of the "system". The portrait will consist of the trends of unionisation and the bargaining practices found at company level. We identify the degree of union presence (and absence) in the firms, the existence or lack of contact and negotiation on the part of companies with the existing unions, and the conformity with collective agreements established at higher levels or management practices which attenuate the application of established agreements. We further look at the degree to which human resource management in the companies has made efforts to individualise the behaviour or aspects of employees' contracts.

The data presented in this chapter derive from two surveys of Portuguese companies (annex). In 1994 we applied a survey of company level labour

9 Due to the absence of relevant data in official surveys of Portuguese companies, these surveys were inspired in part by an effort to adapt the practice of the British "Workplace Employment Relations Survey" to Portuguese companies. On the basis of restricted grants and efforts, it has of course been difficult to achieve the level of receptivity of the British model. A comprehensive introduction to the WERS can be found at http: //www. wers2004.info/wers2004/wers2004. php. 
relations to a sample of companies located in Portugal with 100 or more employees (Stoleroff, 1995). The restriction of the survey object to large (more than 500 employees) and medium (between 100 and 500 employees) companies was due to an attempt to achieve more representative results of industrial relations given the hypothesis that there exists a strong correlation between the dimension of organisation and the propensity for the development of collective relations. ${ }^{10}$ Lacking the resources to the replicate the sample in the earlier survey and having confirmed the hypothesis referred to above, a subsequent survey was conducted in 2003 whose object and sample were limited to labour relations in the biggest Portuguese companies. ${ }^{11}$

\section{Presence and absence of unions at the company level}

The distribution of union membership within companies is the foremost variable in the pattern of union presence at the company level. The unit of measurement concerned is the individual company and the following tables indicate the proportion of companies with a given rate of unionisation. ${ }^{12}$

In effect, the 1994 survey revealed the existence of a large non-unionised sector amongst the large and medium-size companies, that is, a segment of companies with a marginal rate of unionisation of $20 \%$ or less (table 10.1)..$^{13}$ This non-union sector comprised almost half (49\%) of companies with more than 100 employees. As anticipated, there was differentiation in unionisation along the factor of company size between medium and large companies.

10 Dimension is generally referred to as a "context" of organisational systems in the organisational literature. In this sense it is an independent variable. The larger the size of an organisation, the greater should be its tendency towards bureaucratic formality and anonymity in relations. Distancing the employee from agents of authority or making relations more impersonal, the increase in organisational size offers sanctuary, that is, some protection for the employee who seeks collective organisation to promote and defend interests. The smaller the organisation, the greater should be the tendency for the presence of forms of direct supervision. Direct relations tend to expose the employee to personal relations with agents of organisational authority who are a brake with regard to association for questions of defense of interests.

11 Between April and September 2003 a research team from the CIES carried out a survey on practices and policy in the field of human resources and labor relations in the largest companies having activity in Portugal. The survey was a component of the Project "Adaptação Sindical às mudanças socio-económicas e organizacionais" which was coordinated by the author of this chapter and supported financially by the Foundation for Science and Technology (Fundação para a Ciência e Tecnologia).

12 This measure should not be confused with the measure of unionisation as union density in the usual use of the term (which is the ratio of unionised workers to the total of wage salaried workers). Whereas density provides an idea of union strength in relation to a population without consideration of its organisational concentration, this indicator of unionisation by company permits an analysis of union presence in relation to workplaces. For a discussion of measures of unionisation, see Stoleroff and Naumann (1994). 
Table 10.1 Rates of unionisation at company level, 1994

\begin{tabular}{lrrrrrrrrr}
\hline Unionisation & Total & $\begin{array}{c}\text { Less than } \\
500 \\
\text { employees employees }\end{array}$ & $\begin{array}{c}\text { More than } \\
500\end{array}$ & $\begin{array}{c}\text { Family } \\
\text { based } \\
\text { group }\end{array}$ & $\begin{array}{c}\text { public } \\
\text { capital }\end{array}$ & $\begin{array}{c}\text { Portuguese } \\
\text { group }\end{array}$ & $\begin{array}{c}\text { Foreign } \\
\text { group }\end{array}$ & Other & DK/nr \\
\hline More than $90 \%$ & 5.3 & 5.1 & 6.8 & 0.9 & 6.9 & 21.8 & 3.3 & 6.0 & 0.0 \\
From 76\% to $90 \%$ & 7.0 & 5.5 & 17.6 & 5.1 & 33.7 & 7.4 & 9.8 & 1.0 & 19.5 \\
From 51\% to 75\% & 13.1 & 12.0 & 21.2 & 8.9 & 43.1 & 13.4 & 20.6 & 15.0 & 11.2 \\
From 31\% to 50\% & 6.6 & 5.8 & 12.0 & 6.2 & 4.9 & 6.1 & 12.3 & 2.5 & 0.0 \\
From 21\% to 30\% & 8.0 & 8.2 & 6.9 & 11.2 & 0.0 & 2.7 & 7.4 & 2.3 & 13.2 \\
20\% or less & 49.4 & 52.4 & 28.9 & 54.7 & 11.4 & 43.3 & 36.8 & 60.7 & 56.1 \\
DK/nr & 10.5 & 11.0 & 6.6 & 12.9 & 0.0 & 5.3 & 9.8 & 12.6 & 0.0 \\
\hline
\end{tabular}

Note: Weighted results.

Source: survey to the Portuguese mainland companies with at least 100 employees, 1994.

Table 10.2 Representative structures at company level, 1994 (\%)

\begin{tabular}{lccc}
\hline Type of Structure & Total & $\begin{array}{c}\text { Less than } \\
\text { employees }\end{array}$ & $\begin{array}{c}\text { More than } \\
\text { 500 employees }\end{array}$ \\
\hline Union shop stewards & 38.7 & 33.8 & 72.4 \\
Workers commission & 14.7 & 11.1 & 39.7 \\
Health and safety & 32.0 & 27.8 & 60.9 \\
Committee & & & \\
\hline
\end{tabular}

Source: survey to the Portuguese mainland companies with at least 100 employees, 1994.

Unionisation was shown to be marginal in $52 \%$ of medium-sized companies as opposed to $29 \%$ of large companies. Furthermore union stewards could not be found in $61.3 \%$ of companies (table 10.2). The comparison of this observation with that of the distribution of company-level unionization revealed that unionisation is not necessarily accompanied by effective workplace representation, that is, union membership does not securely result in the building of a "domestic organisation". However, the lack of effective representation was especially a characteristic of the medium-sized companies amongst which only $33.8 \%$ were found to have union stewards. The situation was

13 The consideration of rates of unionisation of $20 \%$ or less as marginal is based on judgements deriving from qualitative knowledge of company-level labor relations. The association of a given rate of rate of unionisation with a degree of union effectiveness may depend upon the concentration and the quality of union organisation in the company. A typical problem of unionisation in Portugal is its dispersion among a set of unions in the company. Therefore normally a rate of up to $20 \%$ of the total of employees of a company would be indicative of a lack of union effectiveness and therefore we consider this level to be marginal. 
Table 10.3 Rate of unionisation at company level/sector of activity, 2003 (\%)

\begin{tabular}{lrrrc}
\hline Unionisation & Primary & Secondary & Tertiary & Total \\
\hline Less than $5 \%$ & 61.5 & 38.8 & 31.7 & $38.8(\mathrm{~N}=94)$ \\
$6-20 \%$ & 19.2 & 38.8 & 19.5 & $19.0(\mathrm{~N}=46)$ \\
$21-45 \%$ & 15.4 & 18.7 & 19.5 & $19.8(\mathrm{~N}=48)$ \\
$46-100 \%$ & 3.8 & 20.9 & 29.3 & $22.3(\mathrm{~N}=54)$ \\
$\mathrm{Nr}$ & 3.7 & 6.4 & 8.0 & $6.7(\mathrm{~N}=17)$ \\
\hline
\end{tabular}

Source: survey to the labour relations in the largest companies of mainland Portugal, 2003.

Table 10.4 Representative Structures at Company level, 2003 (\%)

\begin{tabular}{lrc}
\hline Type of Structure & Yes & No \\
\hline Union committee & 28.3 & 71.7 \\
Workers commission & 22.7 & 77.3 \\
Health and safety committee & 55.2 & 44.8 \\
Some other bipartite committee of a consultative nature & 5.9 & 94.1 \\
European works council & 11.7 & 88.3 \\
\hline
\end{tabular}

Source: survey to the labour relations in the largest companies of mainland Portugal, 2003.

inverted in the largest companies of more than 500 employees, $72.4 \%$ of which were found to have union stewards. Taking into consideration that business restructuring was still in an initial phase in 1994, this observation was indicative of a crisis for unions which was characterised by the weakening of union organisation, particularly in the large companies, and by a clear decline of overall unionisation. As can be seen in table 10.1, there was important differentiation between the pattern of union membership in companies whose majority share of capital was public and private companies, an indication of the persistence of a segment of companies where union organisation continued to be relatively protected by the effect of the more secure institutionalisation of industrial relations in the public sector.

Taking into consideration the evolution of Portuguese organisational structure $^{14}$ and the existence of a large non-union sector in the pattern of company-level unionisation, in order to increase the probability of greater union presence in the survey population, it was necessary to concentrate even greater attention upon the larger companies. Therefore in the sub-

14 According to the data of the quadros de pessoal (Staff Charts) in 1999 companies with 100 or more workers represented only $1.1 \%$ of the total of companies and $36.8 \%$ of the workers in Portugal. The largest companies, with 500 or more workers, accounted for $0.1 \%$ of companies and $18.4 \%$ of workers. 
sequent survey of 2003 the object was restricted to labour relations in the largest companies.

In the following table (table 10.3) we present the distribution of unionisation by ranges in the largest companies as found in the survey of 2003 (Stoleroff, 2003). The unit of measurement remains the individual company and the cells indicate a proportion of companies with a given level of unionisation.

Amongst the largest Portuguese companies in 2003 there is a segment which can securely be referred to as non-union which we can estimate as comprising between a third and $58 \%$ of the companies, depending upon which rate is to be considered as a minimum for effective union presence. A stratum equivalent to a fifth of the largest companies, that is, $19.2 \%$ of the companies, report that they have no unionisation. If we consider a rate of unionisation of $5 \%$ or less as basically inexistent union presence, we are confronted with a non-union sector of $38.8 \%$ of the largest companies $-38.8 \%$ in industry and $31.7 \%$ in the services. ${ }^{15}$ There is a stratum of weak and marginal unionisation, between $6 \%$ and $20 \%$ unionisation at company level that accounts for a further $19.0 \%$ of the large companies. In the analysis of the 1994 survey this stratum of companies was considered as marginal, and therefore in order to be consistent with the earlier analysis, we would have to consider the non-union segment within the largest companies as almost $58 \% .{ }^{16}$

The absence of unions found within the stratum of the largest companies is certainly a deep hole in the Portuguese industrial relations system. This reality reflects the present composition of the largest Portuguese companies which suffered major changes with the Europeanisation of the economy (growth of commercial and tertiary organisations and decrease in the average size of industrial companies) and with the changes in economic institutions (such as the dismantling of the state-owned industrial sector). As has been pointed out many times, these changes shook up the basic supports of unionisation, for which the anomalous and curious particularities of Portuguese trade unionism (such as the traditionally high density in banking) do not compensate in terms of the overall system. It amounts to a hole filled by employer unilateralism due to the absence of an actor that can assure the representation of workers at workplace level. This does not mean that labour bargaining does not exist in the sector of the largest companies; to the degree to which

If a rate of unionisation of $10 \%$ or less is considered as beingeffectively a marginal or inexistent union presence, the non-union sector would increase to $50 \%$. If the same range as was used in the survey of 1994 in which a rate of unionisation below $20 \%$ was treated as marginal, the non-union sector in 2003 would increase to as much as $57.9 \%$ of the largest companies.

16 Our experience leads us to associate "no response" in this area - which reach $6.7 \%$ of respondents - with low unionisation, but we opted to not take this into consideration in the presentation of the distribution of results. 
there exist agreements with coverage for the branch, collective bargaining can extend its influence to the companies and, furthermore, there is individual and informal bargaining within the sphere of human resource management, but joint regulation is not present at company level within this important segment of the largest companies.

The union sector consists of firms in which there are significant rates of unionisation and there is much variation in rates of unionisation within this segment. To simplify, on the one hand, there exists a segment with unionisation between $21 \%$ and $45 \%$ that can be referred to as moderately unionised, that is, a segment where between one out of four to one out of almost two employees are unionised. This segment accounts for $19.8 \%$ of the largest companies. On the other hand, there is a significantly unionised segment with a rate of unionisation above $46 \%$, that is, where almost one or more than one out every two workers is unionised; this segment accounts for little more than $22 \%$ of the largest companies. Beyond these segments, there is a niche made up of approximately $10 \%$ of the largest companies where unionisation is high or very high, that is, with rates of membership over $70 \%$.

This observation of the dualism between a union and non-union sector and of the large variation in rates of unionisation in the largest Portuguese companies should allow for the elaboration of a series of hypotheses with regard to the effect that degrees of union presence may have upon labour relations in the companies.

Thus there is a dualism in the structure of industrial relations in Portugal due, in the first place, to the distribution of unionisation at company level. This is a dualism which demarcates organisational strata characterised by the presence or absence of unionisation. Unionisation is a precondition for effective representation of workers and, therefore, where significant unionization does not exist, there are also good chances that other forms of representation will not exist. In this way, this dualism is manifested in other indicators of the density of institutionalised organisation and representation of workers at the company level, such as, for examples, the presence of Workers Commissions or Health and Safety Committees.

In spite of their Constitutional legitimation, the Workers Commissions have a limited presence in the system of employment relations in Portugal. In the Survey of 1994 they were present in only $14.7 \%$ of companies with more than 100 employees (table 10.2). They were found in only $11.1 \%$ of medium sized companies and in $39.7 \%$ of companies with 500 or more employees. The Health and Safety Committees had a fairly irregular presence in the 1994 survey. They existed in only $32.0 \%$ of the companies, that is, in $27.8 \%$ of medium sized and $60.9 \%$ of the largest companies.

In 2003 only $28.3 \%$ of the companies recognised the existence of a Union Committee (table 10.4). Union Committees are made up of union stewards and, therefore, to the extent that these data are comparable with the data 
regarding the presence of union stewards in the companies in 1994, there is evidence of a weakening of union organisation at company level which could derive from the expansion of the non-union sector in the segment of the largest companies. Only $22.7 \%$ of the largest companies reported the existence of a Workers Commission and only 55. 2\% confirmed the existence of a Health and Safety Committee. Considering the supposedly mandatory legal status of the Health and Safety Committees in the large enterprises, the latter result is still more evidence of the non-correspondence between the normative framework of the country and its real institutional development. Therefore, the lack of the committees in a large percentage of the largest companies is even more indicative of the unilateralism that results from the lack of employee representation, in that health and safety issues have strong potential as promoters of consensus in labour relations. If there is not union presence in the company, there is less probability that initiative for the formation of a committee will be taken by informal groups or individuals. ${ }^{17}$

\section{Dualism in the practice of employment regulation}

In the rest of this chapter we will analyse data based mainly upon the hypothesis of dualism. We will analyse the impact of collective agreements upon management decisions regarding wages and working conditions, the contact or negotiation with unions and management practices that attenuate the application of established agreements.

In order to characterise micro and direct regulation of labour relations at the company level, it is necessary to put these relations into the context of their collective bargaining frameworks, which - when existent establish minimum reference points for employment conditions. There is significant variation in practices even when companies are integrated within agreements because branch agreements may be applied directly to a company or used merely as a reference (as a bottom-line or as a take-off point). Collective bargaining agreements may also pertain to a single company (Acordos de Empresa) or a relatively restricted set of companies (Acordos Colectivos de Trabalho) and in these cases there is more likelihood that company practice will coincide with the terms of the collective bargaining agreement. It is also possible to find companies that are not covered by any collective agreement. The surveys analysed here sought to establish the existing bargaining framework but did not inquire specifically about the bargaining practices of the companies or the context of sectoral collective bargaining agreements.

17 The lack of these committees represents an avoidance of responsibility by the two sides in terms; it would be interesting in further research to study the degree to which union presence influences the incipient movement known as "company social responsibility". 


\begin{tabular}{lccrr}
\hline Primary mode & Primary & Secondary & Tertiary & Total \\
\hline No existing contract applicable to the company & 23.1 & 8.9 & 15.7 & 12.7 \\
Sectoral or branch collective agreement & 53.8 & 80.0 & 50.6 & 67.2 \\
Multiple company agreements & 15.4 & 3.7 & 6.0 & 5.7 \\
Single company agreements & 3.8 & 6.7 & 24.1 & 12.3 \\
Extension procedure & 3.8 & 0.7 & 3.6 & 2.0 \\
Total & 100.0 & 100.0 & 100.0 & 100.0 \\
\hline
\end{tabular}

Source: survey to the labour relations in the largest companies of mainland Portugal, 2003.

The results of the 1994 survey showed evidence that sector or branch level bargaining was by far the most prevalent form of collective bargaining in medium and large enterprises in Portugal. According to the data only $8.3 \%$ of medium and large companies governed their labour relations through company-specific agreements, either single company agreements or multiple company agreements. This means that for nearly the entire range of medium and large sized companies negotiation was situated at a level far from the specific realities and concerns of the organisation. (Public enterprises were the notable exception to this tendency in that $58.6 \%$ were governed through such company-specific collective agreements.) In the survey of 2003 (table 10.5) $67.2 \%$ of respondents indicated the existence of a sectoral or branch collective agreement as their regulative framework. Therefore, such sectoral regulation continues to predominate although $5.7 \%$ and $12.3 \%$ of respondents from the largest companies referred respectively to multiple company and single company agreements as their contractual framework. Another 2. $0 \%$ referred that coverage was attained by an extension procedure. Nevertheless $12.7 \%$ of the respondents from the largest companies affirmed that no contract existed that was applicable to the company (4.3\% of respondents didn't answer.)

It is not surprising that in the 2003 survey a higher percentage of companies are regulated by AEs or ACTs in comparison with the entire group of medium and large companies of the 1994 survey considering that, in the former, we are dealing with the largest companies, where frequently there are conditions that justify direct negotiation of specific contract terms; on the contrary, the limitation of this practice to a stratum of only $18 \%$ of the largest companies reveals just how poorly developed is joint regulation (that is, formalised decentralised collective bargaining) at the company level in Portugal. Therefore, the Portuguese industrial relations system could be said to be characterised by a medium degree of centralization of regulation in comparative terms but with a high degree of real decentralisation in the determination of employment conditions. The problem is that this real decentralisation represents the prevalence of employer unilateralism and not decentralised regulation and this finding is buttressed by the further analysis of the data with regard to bilateral contacts 
and negotiation at the company level. Although these assertions do not warrant negating the importance of the well-known cases of companies where deep bargaining has taken place at company level, these results nevertheless accentuate the exceptional character of such cases and their interest for qualitative case study. ${ }^{18}$

In an economy where there is such a large non-union sector, it should not be surprising to find a segment $(12.7 \%)$ of companies in which no regulatory agreement at all is acknowledged, in spite of their presence in the cohort of the largest companies. Though important, this segment is nevertheless not very extensive. Moreover in a certain sense it confirms the greater propensity of the largest companies to have contractual coverage in spite of the absence of significant trade union representation. The question is whether coverage through a sectoral collective agreement has relevance for the effective determination of employment conditions in the companies and whether this coverage is sufficient to provide a platform for further decentralised joint regulation. On the other hand, it is to be supposed that the existence of AEs or ACTs in $18 \%$ of the companies is demonstrative of at least a stratum where effective joint regulation takes place (effectivity given the proximity of the workplace to the specific bargaining process) and that the lack of coverage in another $12.7 \%$ of the companies is demonstrative of employer unilateralism with regard to establishing the norms of employment.

The subsequent question is therefore whether the bargaining agreements establish the rules and procedures effectively applied in the companies. For this reason these surveys sought to ascertain how remuneration and general employment conditions are effectively established, that is, whether they are established in a unilateral manner (by management decree with or without reference to the agreement that might exist in the sector) or through the application of the terms of a collective agreement or, even still, in a differentiated and individualised manner. Another measure of the degrees of joint regulation and unilateralism in the pattern would be the existence of negotiation at the company level between workers' representatives, especially the unions, and the company, even if such negotiation were to take place informally. Therefore the surveys formulated further questions to determine whether contacts or forms of negotiation between worker representatives and management exist at the company level.

In the 1994 survey $54.6 \%$ of the companies reported that at the last opportunity wages were established by a management decision to directly apply a collective agreement. Negotiation at company level was rare; only

18 The reference is specifically to the case of Autoeuropa where an agreement was negotiated and obtained in 2003 between the Workers Comission and the company outside of institutional collective bargaining and which established wage, working time and other conditions as well as an agreement to stabilise employment during a specified period. 
Table $\mathbf{1 0 . 6}$ Process of wage fixing, 2003 (\% and valid \%)

\begin{tabular}{lrr}
\hline Process of wage fixing & $\%$ & valid \% \\
\hline Management decision, direct application of contract & 22.4 & 25.0 \\
Management decision following consultation with representatives of workers & 8.6 & 9.6 \\
Negotiation, even if only informal, with representatives of workers & 9.8 & 11.0 \\
Flexibilised, individualised, decentralised, according to results & 48.6 & 54.4 \\
Total & 89.4 & 100.0 \\
\hline
\end{tabular}

Source: survey to the labour relations in the largest companies of mainland Portugal, 2003.

Table 10.7 Wage determination, by sector, $2003(\%)$

\begin{tabular}{lcccc}
\hline Wage determination & Primary & Secondary & Tertiary & Total \\
\hline $\begin{array}{l}\text { Rigorously apply levels published in } \\
\text { collective agreement }\end{array}$ & 34.6 & 5.1 & 27.9 & 16.1 \\
$\begin{array}{l}\text { Pay generally and uniformly above levels } \\
\text { published in collective agreements }\end{array}$ & 65.4 & 94.9 & 72.1 & 83.9 \\
\begin{tabular}{l} 
Total \\
\hline
\end{tabular} & 100.0 & 100.0 & 100.0 & 100.0 \\
\hline
\end{tabular}

Source: survey to the labour relations in the largest companies of mainland Portugal, 2003.

$10.2 \%$ of the companies reported that a management decision was preceded by consultation or conversations with representatives of the workers and in only $5.9 \%$ of the cases was the effective pay award established through either formal or informal negotiation. Remuneration was reported by $26.6 \%$ of the companies to have been determined in a flexible, decentralised and individualised manner (the percent of companies which did not respond to this question was $2.7 \%$.)

The 2003 survey revealed that the way in which companies established pay at the last opportunity was through management decision through direct application of an agreement in $22.4 \%$ of the largest companies. Remuneration was established by management decision following consultation or conversations with workers' representatives in $8.6 \%$ of the companies and by formal or informal negotiation with workers' representatives in $9.8 \%$. Nevertheless, in $48.6 \%$ of the companies, remuneration was established in a flexible, individualised or decentralised manner (there were $10.6 \%$ of companies that did not respond to this question.)

A manifestation of the distance between formal collective bargaining and the effective determination of employment conditions at the company level is the fairly generalised tendency of a discrepancy between the real pay 


\begin{tabular}{lrr}
\hline Process of fixing & $\%$ & valid \%) \\
\hline Management decree & 36.1 & 37.7 \\
Direct application of a contract & 9.8 & 10.2 \\
Management decision following consultation with representatives of workers & 3.9 & 4.1 \\
Negotiation, even if only informal, with representatives of workers & 8.2 & 8.6 \\
Flexibilised, individualised, decentralised, according to results & 37.6 & 39.3 \\
Total & 95.7 & 100.0 \\
\hline
\end{tabular}

Source: survey to the labour relations in the largest companies of mainland Portugal, 2003.

levels applied in the companies and the protocols established in contracts. In 1994 it had been verified that the great majority, almost $75 \%$ of medium and large companies, were paying wages above the levels agreed in collective bargaining. (A smaller percentage of public enterprises were paying above contract given their greater coverage through AEs and ACTs, that is, by agreements that were necessarily produced in greater proximity to the specific realities of the company.) In 2003, $16.1 \%$ of the companies claimed to rigorously apply the contract protocols in matters of remuneration while 83 . $9 \%$ responded that they pay generally and uniformly above the levels agreed upon in the contract of the sector. Thus, in spite of the importance of collective bargaining coverage in general, in 2003 more than $4 / 5$ of the largest companies claimed to compensate their employees above contract levels. Even more noteworthy is what is found in the secondary sector, where nearly the totality of the largest companies claimed to pay employees above contract scales. Even in the primary and tertiary sectors a third or more of the companies claimed to be paying above the levels established by collective bargaining agreements.

In relation to working conditions in general, in 1994, 46.1\% of the companies had established non-pay conditions of employment by a management decision to directly apply the terms of an agreement. Management decisions were preceded by consultation or conversations with workers' representatives in $11.0 \%$ of the companies. In $32.8 \%$ of the companies working conditions were established in a flexible, individualised or decentralised manner. In $6.2 \%$ of the cases work conditions were established through formal or informal negotiation with representatives of the workers. (There was no answer from $3.8 \%$ of the companies.) In 2003, 36.1\% of the largest companies established general working conditions exclusively by management decision, $9 \%$ by application of a collective bargaining agreement, $3.9 \%$ by a management decision following consultation or conversations with workers' representatives and $8.2 \%$ claimed that conditions were established on the basis of formal or informal negotiation with workers' representatives. However, $37.6 \%$ of the 


\begin{tabular}{lcccc}
\hline In this company there take place: & Regularly & $\begin{array}{c}\text { At specific } \\
\text { moments }\end{array}$ & Never & $\begin{array}{c}\text { No } \\
\text { response }\end{array}$ \\
\hline $\begin{array}{l}\text { Meetings to disseminate information to the } \\
\text { workers }\end{array}$ & 36.9 & 56.9 & 5.1 & 1.2 \\
$\begin{array}{l}\text { Informational meetings with union stewards and } \\
\text { other representatives of the workers }\end{array}$ & 23.1 & 21.2 & 49.4 & 6.3 \\
\hline
\end{tabular}

Source: survey to the labour relations in the largest companies of mainland Portugal, 2003.

companies claimed to fix conditions in a flexible, individualised or decentralised manner (there was no from $4.3 \%$.)

In the 2003 survey $76.5 \%$ of the companies responded that no other form of negotiation existed with the representatives of the workers. Only $18.8 \%$ of the companies responded that some other form of negotiation, formal or informal, having specifically to do with the company takes place between management and representatives of staff. According to the reporting, when this type of negotiation takes place it most commonly concerns pay. Considering that $11.8 \%$ of the managers had indicated that their company is covered by an Acordo de Empresa (which necessarily means company-specific negotiation), we may conclude that there is a stratum of companies, possibly up to $10 \%$ of the largest companies, in which some form of company-level negotiation exists which goes beyond the range of conventional collective bargaining. There is a statistically significant association between the level of unionisation and the existence and non-existence of informal negotiation. In other words, as would be expected, the companies of the unionised sector more frequently engage in informal negotiation than the non-union sector. The result is consistent with the results referred to above.

Therefore, we find evidence here of a dualism: a fairly extensive stratum in which important elements of employment relations have been individualised, probably associated with the absence of significant unionism, and a stratum in which joint regulation is pertinent at the company level and goes beyond the mere sphere of collective bargaining. However, this dualism is exacerbated by the mere formality of the collective agreements in a significant segment of the largest companies where the contract agreement has the function of simply indicating a minimum threshold for the effective determination of employment conditions by management discretion. This dualism is a manifestation of the differentiation of the Portuguese industrial relations system between a non-union sector and a union sector and is certainly a problem which deserves further research. 
The absence of unions in a large stratum of the largest Portuguese companies is also reflected by the mechanisms that management uses to disseminate information to workers. To the 1994 survey, 52.2\% of respondents claimed to never hold meetings with union stewards or worker representatives for the communication of information. On the other hand, informational meetings were held with representatives of the workers in $38.8 \%$ of the companies and in $19.1 \%$ of the companies such meetings were held regularly. In 2003 the results of the survey of the largest companies revealed that $49.4 \%$ of the respondents indicated never holding meetings with stewards or worker representatives for this effect. On the other hand, informational meetings with workers' representatives had been held in $44.3 \%$ of the companies and in $23.1 \%$ of these companies these meetings were held regularly. For the results of the 2003 survey the differentiation between companies with regard to information meetings is statistically significant on the basis of the level of unionisation. This is therefore one more powerful manifestation of the dualism between union and non-union sectors in Portuguese labour relations.

\section{The role of the unions}

In both the surveys reported here we sought to identify the presence of unilateralist or pluralist attitudes in the managers' evaluations of the role of the unions in the company.

In the 1994 survey the following question sought to ascertain the attitudes towards unions from the point of view of the good of the company: "How do you consider the role of the unions with respect to labour relations within the company from the perspective of the company?"

Somewhat more than half of the managers surveyed showed a pluralist viewpoint in their evaluation, considering the role of the unions within the company as "acceptable". However the percentage of managers with this evaluation was larger in the large companies. The managers of public enterprises had a stronger tendency to value the role of the unions. The managers of foreign and family-based companies had a stronger tendency to consider the unions as detrimental. Nevertheless, the predominant view amongst managers of Portuguese companies was of simple acceptance of the unions.

A following question sought to have the managers characterise even more explicitly the role of the unions in their company according to three options:

- the unions are a partner in the life of the company;

- the unions are a reality that it is necessary to account for;

- the unions are an obstacle to the freedom to human resource management in the company that would be desirable to lessen. 
Table 10.10 Opinion with regard to the role of unions in the view of the company, 1994 (\%)

\begin{tabular}{|c|c|c|c|c|c|c|c|c|c|}
\hline & Total & $\begin{array}{l}\text { Less than } \\
500 \\
\text { employees }\end{array}$ & $\begin{array}{c}\text { More than } \\
500 \\
\text { employees }\end{array}$ & $\begin{array}{l}\text { Family } \\
\text { based } \\
\text { group }\end{array}$ & $\begin{array}{c}\text { Public } \\
\text { enterprise }\end{array}$ & $\begin{array}{l}\text { Portu- } \\
\text { guese } \\
\text { group }\end{array}$ & $\begin{array}{l}\text { Foreign } \\
\text { enterprise }\end{array}$ & Other & $\mathrm{Dk} / \mathrm{n}$ \\
\hline Advantageous & 11.3 & 7.3 & 19.3 & 7.3 & 35.3 & 9.3 & 13.0 & 15.4 & 0.0 \\
\hline Acceptable & 54.4 & 52.7 & 57.8 & 53.6 & 47.1 & 72.1 & 47.8 & 38.5 & 83.3 \\
\hline Detrimental & 19.0 & 20.0 & 16.9 & 21.8 & 5.9 & 9.3 & 26.1 & 23.1 & 0.0 \\
\hline $\mathrm{Dk} / \mathrm{nr}$ & 15.3 & 20.0 & 6.0 & 17.3 & 11.8 & 9.3 & 13.0 & 23.1 & 16.7 \\
\hline
\end{tabular}

Note: non-weighted data.

Source: survey to the Portuguese mainland companies with at least 100 employees, 1994.

Table 10.11 Characterisation of the role of the unions, 1994 (\%)

\begin{tabular}{|c|c|c|c|c|c|c|c|c|c|}
\hline & Total & $\begin{array}{l}\text { Less than } \\
500 \\
\text { employees }\end{array}$ & $\begin{array}{l}\text { More than } \\
500 \\
\text { employees }\end{array}$ & $\begin{array}{l}\text { Family } \\
\text { based } \\
\text { group }\end{array}$ & $\begin{array}{c}\text { Public } \\
\text { enterprise }\end{array}$ & $\begin{array}{l}\text { Portu- } \\
\text { guese } \\
\text { group }\end{array}$ & $\begin{array}{l}\text { Foreign } \\
\text { enterprise }\end{array}$ & Other & $\mathrm{Dk} / \mathrm{nr}$ \\
\hline Partnership & 26.2 & 23.6 & 31.3 & 20.9 & 41.2 & 30.2 & 28.3 & 34.6 & 0.0 \\
\hline $\begin{array}{l}\text { Reality to take into } \\
\text { account }\end{array}$ & 42.3 & 38.2 & 50.6 & 40.0 & 47.1 & 51.2 & 41.3 & 26.9 & 83.3 \\
\hline $\begin{array}{l}\text { Ostacle to the } \\
\text { company }\end{array}$ & 13.7 & 15.8 & 9.6 & 16.4 & 5.9 & 11.6 & 17.4 & 7.7 & 0.0 \\
\hline $\mathrm{Dk} / \mathrm{nr}$ & 17.7 & 22.4 & 8.4 & 22.7 & 5.9 & 7.0 & 13.0 & 30.8 & 16.7 \\
\hline
\end{tabular}

Source: survey to the Portuguese mainland companies with at least 100 employees, 1994.

Only $13.7 \%$ of the surveyed managers considered the unions to be an obstacle to the company, indicating a relatively weak explicitly anti-union tendency amongst the managers, especially given the significantly larger percentage of those who indicated acceptance of the unions as a partner in the company. A plurality of managers considered the unions merely a reality that is necessary to take into account, which does not imply a necessarily positive evaluation, but also does not imply an aggressive posture in relation to the unions. The managers of foreign and family-based companies indicated a stronger tendency to desire to mitigate the effect of the unions. The managers of public enterprises showed a stronger tendency to consider the unions as a partner in the company.

There seems to be a logic to the tendencies of these evaluations. In the public sector there existed an ideology of the public enterprise; both experience as well as legal norms legitimated unions. The unions do not enjoy such legitimation and protection within the private companies and thus are accepted but not necessarily wanted or may even be considered dispensable. 
Table 10.12 Characterising the role of unions from the perspective of the company, 2003 (\%)

\begin{tabular}{lccccc}
\hline & Detrimental & Indifferent & Acceptable & Advantageous & No response \\
\hline $\begin{array}{l}\text { The role of unions in labour } \\
\text { relations within the company }\end{array}$ & 9.8 & 31.8 & 30.6 & 9.4 & 18.4 \\
\hline
\end{tabular}

Source: survey to the labour relations in the largest companies of mainland Portugal, 2003.

Table 10.13 Role of unions from the perspective of the company by sector

\begin{tabular}{lccc}
\hline & $\begin{array}{c}\text { Non-unionised sector or } \\
\text { marginal unionisation }\end{array}$ & Unionised Sector & Total \\
\hline Detrimental & 11.6 & 13.0 & 12.4 \\
Indifferent & 60.5 & 24.3 & 39.8 \\
Acceptable & 22.1 & 46.1 & 35.8 \\
Advantageous & 5.8 & 16.5 & 11.9 \\
Total & 100.0 & 100.0 & 100.0 \\
\hline
\end{tabular}

Source: survey to the labour relations in the largest companies of mainland Portugal, 2003.

The questionnaire of 2003 repeated the above question with a minor alteration, soliciting from the managers a general evaluation of the role of the unions in the company. In response to this question the managers most frequently evaluated the unions' role as being indifferent or acceptable. Almost $10 \%$ of the managers considered the unions' role as detrimental to their companies and another $9.4 \%$ considered them to be advantageous for their companies. (A significant proportion of managers did not respond to this question but it seems reasonable that the non-responses would be associated with the non-union sector where it could be thought that the question simply does not apply.) Thus, it seems that the large majority of managers of the largest companies regard the unions simultaneously with tolerance and disdain.

The considerations of the unions as "acceptable" or "advantageous" are statistically more associated with companies from the union sector and the considerations of "indifferent" or detrimental" correspond to companies within the non-unionised sector. A disaggregated analysis confirms the sense of these results. Statistically the perception of the unions as indifferent is more strongly associated with companies without unionisation or with weak unionisation; the perception of the unions as acceptable is more associated with companies with moderate unionisation; the perception of the unions as advantageous is more associated with companies with a higher level of unionisation. Nevertheless, 
$13.9 \%$ of the managers of the union sector considered the unions to be detrimental to their companies and $24.3 \%$ considered the unions indifferent.

\section{Conclusion: the dualism in the structure of industrial relations at company level}

The systems paradigm in the study of employment relations has been corroded by the evolution of the last decades in the majority of industrialised countries, with perhaps the Scandanavian countries making up the major exception to this general tendency (Hoffman and Waddington, 2000). A sequence of processes such as economic globalisation and its consequences for employer strategy, de-unionisation, the decentralisation of bargaining, etc. have resulted in a weakening of the supports of industrial relations systems and the Dunlopian perspective (Kochan, McKersie and Capelli, 1984; Erickson and Kuruvilla, 1998), giving rise to relatively hybrid forms of regulation in which collective bargaining has a reduced relevance, even when national labour law facilitates maintaining the coverage of established collective bargaining agreements. In this context the paradigm has even been put in question. It has been questioned, for example, whether the development of human resource management, with its emphasis on the individualised employment relation, is compatible with the working of joint regulation on the basis of collective bargaining (Guest, 1995). The introduction of "high performance" work systems in the context of the increased competition due to globalisation has also been considered to challenge the industrial relations paradigm. ${ }^{19}$

It is generally accepted that with democratisation Portugal passed through a phase of the constitution of industrial relations systems. Indicators of this process were the growth of unionisation and the generalisation of collective bargaining up to the mid-1980s. There emerged a model of articulation between the levels of an industrial relations system with its pivot in the role of the State in the nationalised and public sector and on the basis of the recognition of union organisation in the companies. However a new unilateralism emerged in employment relations in Portugal in the phase of development following the crisis of 1983-85. On the one hand, in a changed social-political context, there began a phase of restructuring, especially of the large enterprises, resulting in a general job insecurity which, in its turn, produced deunionisation either through job loss or through the loss of conditions favourable to unionisation (Stoleroff, 2001). The massive privatisation of nationalised enterprises created autonomous decision-making centres and attenuated the bargaining dynamics that had been established under state tutorship.

19 The relevant debates in the pages of Industrial $\mathcal{E}$ Labor Relations Review raised many of the issues involved in this challenge. See Godard and Delaney (2000), Kochan (2000) and Godard and Delaney (2002). 
In this context the articulation between the systems of industrial relations linking the meso branch-level of activity with the micro company-level was increasingly weakened, leading to the dualisation that has been the focus of this chapter. At the meso level of centralisation, that is, of the branches of activity, actors are present, namely employer associations and union organisations and, to a certain extent, bargaining takes place - even if it is partial, fragmented and inconclusive. ${ }^{20}$ At this meso level the lack of mechanisms for determining union representativity still make it possible that mutually recognised - but not necessarily representative - actors engage in bargaining and reach agreements. The achievements of such selective agreements thereby maintain coverage, regardless of how formalised and watered down they made be. At the company level however criteria of representativity exist de facto, that is, as a result of the manifest capacities of a union or unions to demand recognition. Negotiation and, therefore, joint regulation depend fundamentally upon a sufficient union presence to impose this recognition. At the company level the presence of a sufficient critical mass of unionisation is the necessary condition for joint regulation. Without this condition not only are company-specific employment conditions established unilaterally but the terms of the formal collective bargaining agreements of the meso level also lose their effectivity.

The results presented here demonstrate the dualisation existing in employment relations in Portugal at the level of companies and organisations between and union sector and a non-sector sector. It is our argument that the systems paradigm of industrial relations loses a great deal of its pertinence to the degree that this dualisation is present. There exists a relatively small segment of the economy where there are systematized industrial relations, that is, where there is articulation between collective bargaining and negotiation at the company or organisational level. There exists a relatively large segment where collective bargaining may be respected but has little effectivity, either because it establishes at most a minimum floor that has been surpassed by the companies or because there is no contract applicable for the effect. The existence of these latter practices - together with the lack of an effective union presence - situates the majority of the largest Portuguese companies in the realm of unilateralism. This produces the isolation of a segment of the union sector where joint regulation does effectively exist and therefore the paradigm of an articulated industrial relations system is relevant to only a small segment of the Portuguese economy.

20 This chapter's surveys were carried out before the Código do Trabalho, the comprehensive revision of Portugal's labour legislation, was promulgated in 2003. The changes in the validity of collective agreements that made it possible for agreements to lose effect if not renegotiated within specified time limits has had a significant effect upon collective bargaining coverage. 


\section{Annex referring to the two surveys}

The universe of the 1994 survey was composed of the companies located in mainland Portugal with 100 or more employees, excluding the primary sector (agriculture, silviculture, hunting, fishing), the extractive industries, the companies in the sector producing electricity, gas and water and the public service sector, social services and personal services.

The sample was stratified on the basis of the variables of size (number of workers: 100 to 499,500 and more) and branch of activity (11 branches).

The distribution of the sample throughout the strata was non-proportional in order to increase representation of the rarer strata. As a consequence, in the analysis of data with regard to specific items of analysis the sample was reweighted such that the strata would reattain the weight that they have in the universe.

The sample was made up of 248 enterprises. In each stratum selection was random on the basis of a data base provided by the Departamento de Estatística do Ministério do Emprego e da Segurança Social (Ministry of Labour and Social Security Statistical Department).

The data was collected through direct interview on the basis of a structured questionnaire. The head of Human Resources was interviewed in each company.

The object of the 2003 survey was restricted to labour relations in the largest companies operating in Portugal. Taking into account all areas of activity, 19 branches were identified as strata ${ }^{21}$ (agriculture, fishing, husbandry and silviculture; extractive industries; construction and public works; food and tobacco; textiles and leather; woodworking, furniture, cork and paper and printing; chemicals, petroleum and rubber; stone/ceramic/glass/ciment; steel, machinery, metallurgy; electronics; vehicle manufacture and equipment; diverse manufacturing; transportation and storage; communications, electricity, water and gas; retail and wholesale commerce; automobile concession and services; hotels, restaurants, tourism; real estate, finance and insurance; diverse services ${ }^{22}$ ).

The universe of the largest companies in Portugal was composed through the identification and inclusion of the 30 largest companies within mainland Portugal for each of the branches, in accordance with the volume of its business, making a total for the universe of 570 companies. The companies for each branch were ordered in accordance with the number of employees of the company. The main source of identification of the companies was

21 With the exceptions of public administration and civil service, education, health and social services.

22 The sector of Diverse Services is a residual category although consulting services, temporary employment agencies and advertising agencies were excluded due to the particularity of the employment relations in these areas. 
the listing of the 7,500 largest companies of DNBPEP, and the financial sector was complemented through consultation of the 1,000 largest companies of DN Empresas 2002.

The survey of the companies took place between April and September of 2003.

Contact with the companies was always initially direct by telephone call to a head of Human Resources or the person with responsibilities at the highest level for labour relations. The questionnaires were sent and returned through post or e-mail. Each respondent was followed by phone contact until delivery of the questionnaire or refusal to respond.

The final universe was made up of 509 companies $^{23}$ and 255 completed questionnaires were received, corresponded to a return rate of $50.08 \%$. The branch with the great response rate was Transportation and Storage $(56.7 \%)$, while Chemicals, Petroleum and Rubber (26.7\%) provided the lowest return.

\section{References}

Batstone, E., I. Boraston, and S. Frenkel (1977), Shop Stweards in Action, Oxford, Basil Blackwell.

Clegg, H. A. (1976), Trade Unionism under Collective Bargaining. A Theory Based on Comparisons of Six Countries, Oxford, Blackwell Publishers.

Dunlop, J. (1958), Industrial Relations Systems, New York, Henry Holt \& Co.

Erickson, C. L., and S. Kuruvilla (1998), "Industrial relations system transformation", Industrial and Labor Relations Review, 52 (1), October.

Godard, J., and J. T. Delaney (2000), "Reflections on the 'high performance' paradigm's implications for industrial relations as a field", Industrial and Labor Relations Review, April, 53 (3).

Godard, J., and J. T. Delaney (2002), “On the paradigm guiding industrial relations theory and research: reply to Thomas A. Kochan", Industrial and Labor Relations Review, April, 55 (3).

Guest, D. (1995), "Human resource management, trade unions and industrial relations" in J. Storey, (ed.), Human Resource Management. A Critical Text, London, Routledge.

Guest, D. et al. (2008) “Does partnership at work increase trust? An analysis based on the 2004 Workplace Employment Relations Survey", Industrial Relations Journal, 39 (2): 124-152.

Hoffman, R., and J. Waddington, eds. (2000), Trade Unions in Europe. Facing Challenges and Searching for Solutions, Brussels, ETUI.

Hyman, R. (1972), Strikes, Glasgow, Fontana/Collins.

23107 companies were withdrawn from the original calculation of the universe because they did not fulfill criteria of dimension, or because of closure or acquisition by another company. 
Gunther, R., P. N. Diamandouros, and H.-J. Puhle (1995), “Introduction” in R. Gunther, P. N. Diamandouros and H. -J. Puhle (eds.), The Politics of Democratic Consolidation. Southern Europe in Comparative Perspective, Baltimore, The Johns Hopkins University Press.

Kaufman, Bruce E. (2004), The Global Evolution of Industrial Relations, Geneva International Labour Organization.

Kerr, C., et al. (1964), Industrialism and Industrial Man, Oxford, Oxford University Press.

Kochan, T. A. (2000), “Comment on John Godard and John T. Delaney, 'Reflections on the High Performance Paradigm's Implications for Industrial Relations as a Field'", Industrial and Labor Relations Review, 53 (4).

Kochan, T., R. McKersie and P. Capelli (1984), “Strategic Choice and Industrial Relations Theory", Industrial Relations, 23 (1).

Martins, A., et al. (2004), "On the Problem of governability in collective bargaining: the cases of Spain and Portugal", paper presented to the $7^{\text {th }}$ IIRA European Regional Congress, Lisbon, Portugal, 7-11 September 2004.

Santos, B. de Sousa (1985), “Estado e sociedade na semiperiferia do sistema mundial: o caso português", Análise Social, XXI (87-88-89).

Schmitter, P. (1995), “Organized interests and democratic consolidation in Southern Europe" in R. Gunther, P. N. Diamandouros and H. -J. Puhle (eds.) The Politics of Democratic Consolidation: Southern Europe in Comparative Perspective, Baltimore, The Johns Hopkins University Press.

Stoleroff, A. (1990), “O padrão emergente das relações industriais em Portugal: uma abordagem sistémica", Organizações e Trabalho, 2.

Stoleroff, A. (1995), “Elementos do padrão emergente de relações industriais no contexto da restruturação: alguns resultados de um inquérito nacional às médias e grandes empresas", Organizações e Trabalho, 13.

Stoleroff, A. (1996), "Sociologia e a gestão de recursos humanos", Organizações e Trabalho, 15.

Stoleroff, A. (2001), “Unemployment and trade union strength in Portugal” in Nancy Bermeo (ed.), Unemployment's in the New Europe, Cambridge, Cambridge University Press.

Stoleroff, A. (2003), “Recursos humanos e relações laborais: inquérito às maiores empresas em Portugal”, CIES, November.

Stoleroff, A. e R. Naumann (1994), “A sindicalização em Portugal: a sua medida e a sua distribuição", Sociologia, Problemas e Práticas, 14, pp. 19-47.

Traxler, F. Blaschke, S. Kittel, B. (2001), National Labour Relations in Internationalized Markets. A comparative Study of Institutions, Change and Performance, Oxford, Oxford University Press.

Visser, J. (1996), "Traditions and transitions in industrial relations: a European view" in J. van Ruysseveldt and J. Visser (eds.), Industrial Relations in Europe: Traditions and Transitions, London, Sage. 